Nevada

Environmental

Restoration

Project

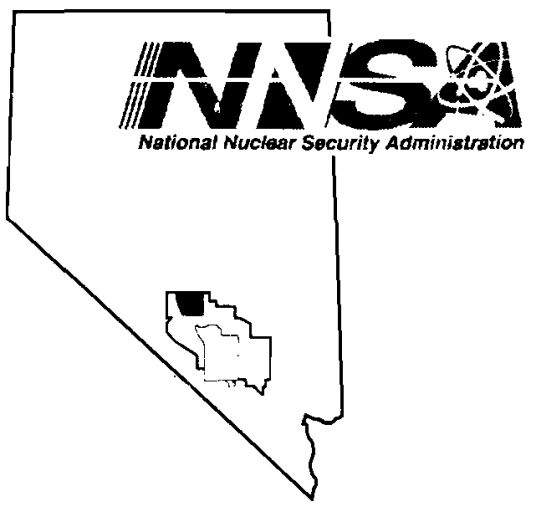

Tonopah Test Range Post-Closure Inspection Annual Report, Tonopah Test Range, Nevada Calendar Year 2003

Controlled Copy No.:

Revision: 0

April 2004

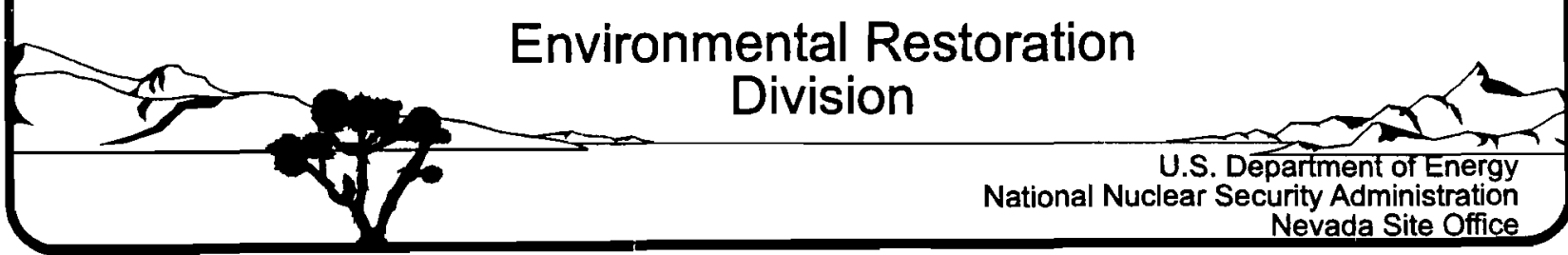




\section{DISCLAIMER}

Reference herein to any specific commercial product, process, or service by trade name, trademark, manufacturer, or otherwise, does not necessarily constitute or imply its endorsement, recommendation, or favoring by the U.S. Government or any agency thereof or its contractors or subcontractors.

This report has been reproduced directly from the best available copy.

Available for sale to the public from:

U.S. Department of Commerce

National Technical Information Service

5285 Port Royal Road

Springfield, VA 22161-0002

Telephone: (800) 553-6847

Fax: (703) 605-6900

E-mail: orders@ntis.gov

Online ordering: http://www.ntis.gov/ordering.htm

Available electronically at http://uww.gov/bridge.

Available for a processing fee to the U.S. Department of Energy and its contractors, in paper, from:

U.S. Department of Energy

Office of Scientific and Technical Information

P.O. Box 62

Oak Ridge, TN 37831-0062

Telephone: (865) 576-8401

Fax: (865) 576-5728

E-mail: reports@adonis.osti.gov 


\title{
Tonopah Test Range Post-Closure Inspection Annual Report Tonopah Test Range, Nevada Calendar Year 2003
}

\author{
Prepared for \\ U. S. Department of Energy \\ National Nuclear Security Administration \\ Nevada Site Office \\ Work Performed Under Contract No. \\ DE-AC08-96NV11718
}

Controlled Copy No.:

Revision: 0

April 2004 
THIS PAGE INTENTIONALLY LEFT BLANK 


\section{TONOPAH TEST RANGE ANNUAL POST-CLOSURE INSPECTION REPORT FOR SITES TONOPAH TEST RANGE, NEVADA CALENDAR YEAR 2003}

Approved by:

Kevin J. Cabble, Acting Project Manager Industrial Sites Project

Approved by:

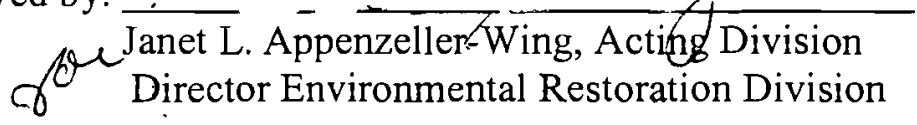

Date: $4-22-04$

Date: $4 / 22 / 04$ 
THIS PAGE INTENTIONALLY LEFT BLANK 


\section{TABLE OF CONTENTS}

LIST OF ACRONYMS AND ABBREVIATIONS ............................................................ ix

EXECUTIVE SUMMARY ........................................................................................

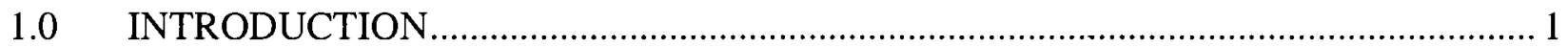

1.1 CLOSURE REPORT CONTENTS ....................................................... 3

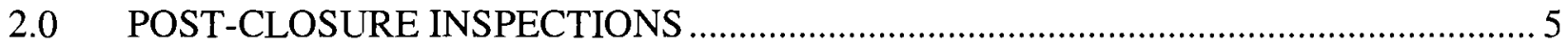

2.1 CAU 400 Bomblet Pit and 5 Points Landfill...................................................... 5

2.1.1 CAU 400 Introduction.................................................................. 5

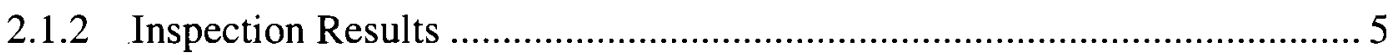

2.1.2.1 CAU 400 First Semiannual Inspection ................................... 5

2.1.2.2 CAU 400 Second Semiannual Inspection ................................ 8

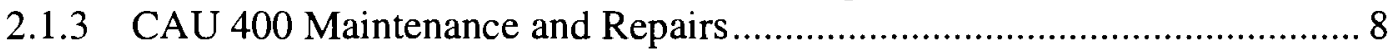

2.1.4 CAU 400 Conclusions and Recommendations ...................................... 8

2.2 CAU 404 Roller Coaster Lagoons and Trench .............................................. 9

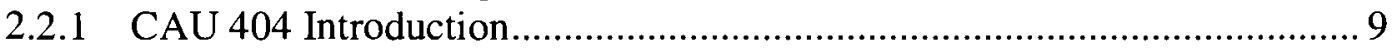

2.2.2 CAU 404 Inspection Results ........................................................ 9

2.2.2.1 CAU 404 First Semiannual Inspection ..................................... 9

2.2.2.2 CAU 404 Second Semiannual Inspection ............................... 11

2.2.3 CAU 404 Maintenance and Repairs...................................................... 11

2.2.4 CAU 404 Conclusions and Recommendations ..................................... 11

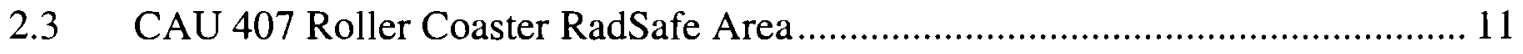

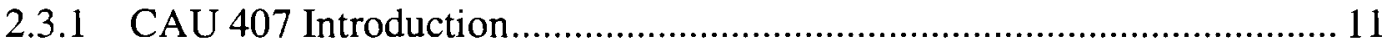

2.3.2 CAU 407 Inspection Results ......................................................... 12

2.3.2.1 CAU 407 First Semiannual Inspection ................................ 12

2.3.2.2 CAU 407 Second Semiannual Inspection .............................. 12

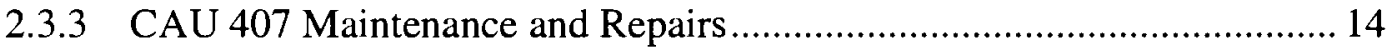

2.3.4 CAU 407 Conclusions and Recommendations ..................................... 14

2.4 CAU 424 Area 3 Landfill Complexes.......................................................... 14

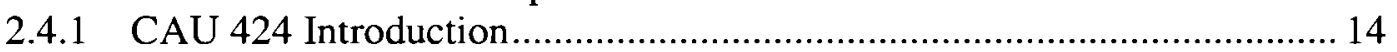

2.4.2 CAU 424 Inspection Results ..................................................... 16

2.4.2.1 CAU 424 First Semiannual Inspection .................................... 16

2.4.2.2 CAU 424 Second Semiannual Inspection .............................. 17

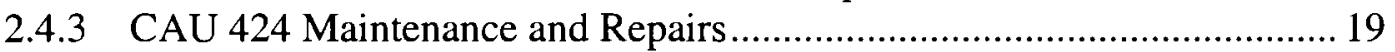

2.4.4 CAU 424 Conclusions and Recommendations ....................................... 19

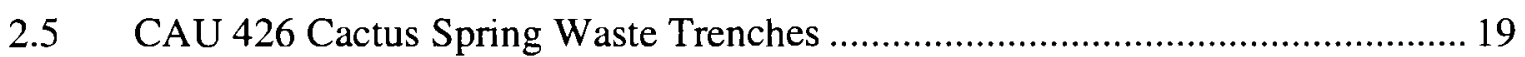

2.5.1 CAU 426 Introduction..................................................................... 19

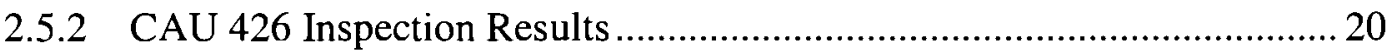

2.5.2.1 CAU 426 First Semiannual Inspection ................................. 20

2.5.2.2 CAU 426 Second Semiannual Inspection ............................... 20

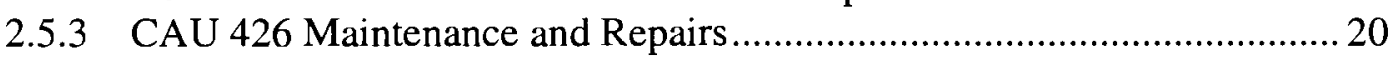

2.5.4 CAU 426 Conclusions and Recommendations .................................... 22 


\section{TABLE OF CONTENTS (continued)}

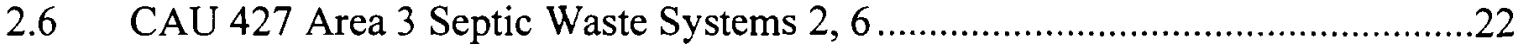

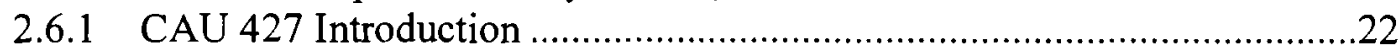

2.6.2 CAU 427 Inspection Results.........................................................22

2.6.2.1 CAU 427 First Semiannual Inspection ..................................22

2.6.2.2 CAU 427 Second Semiannual Inspection.............................24

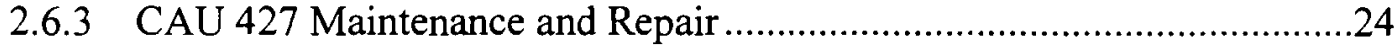

2.6.4 CAU 427 Conclusions and Recommendations.......................................24

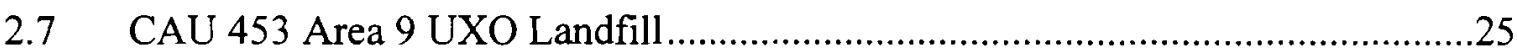

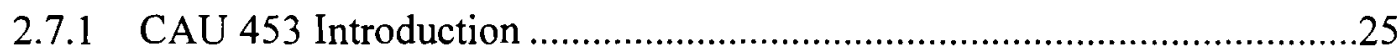

2.7.2 CAU 453 Inspection Results.........................................................25

2.7.2.1 CAU 453 First Semiannual Inspection .................................25

2.7.2.2 CAU 453 Second Semiannual Inspection................................25

2.7.3 CAU 453 Maintenance and Repairs ..................................................27

2.7.4 CAU 453 Conclusions and Recommendations.....................................27

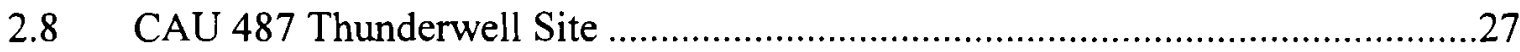

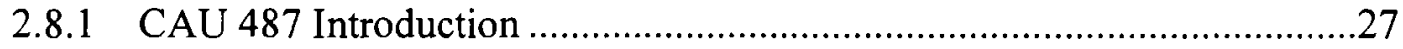

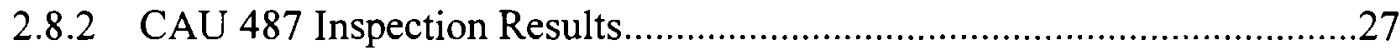

2.8.3 CAU 487 Maintenance and Repairs ...............................................28

2.8.4 CAU 487 Conclusion and Recommendations ....................................28

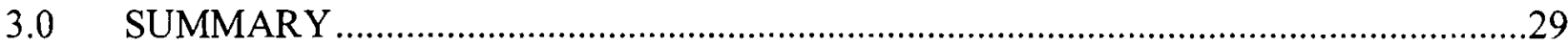

3.1 CAU 400 Bomblet Pit and Five Points Landfill .............................................29

3.2 CAU 404 Roller Coaster Lagoons and Trench ...............................................29

3.3 CAU 407 Roller Coaster RadSafe Area............................................................30

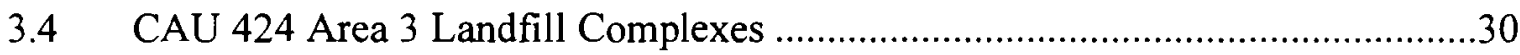

3.5 CAU 426 Cactus Spring Waste Trenches........................................................

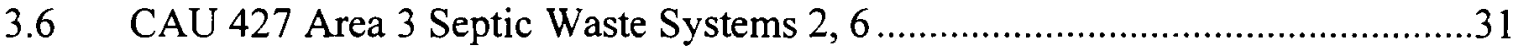

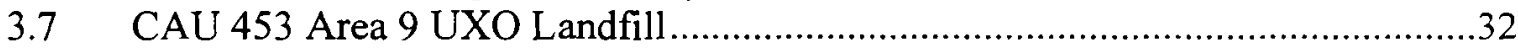

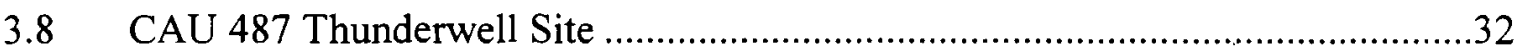

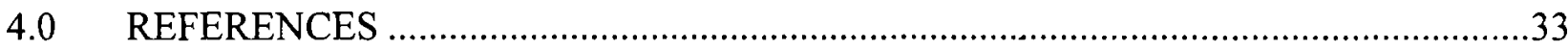

\section{FIGURES}

FIGURE 1 - TONOPAH TEST RANGE POST-CLOSURE MONITORING SITES

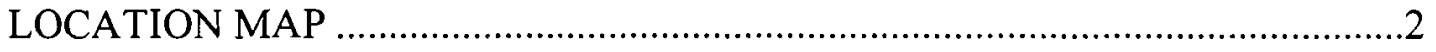

FIGURE 2 - CAU 400 BOMBLET PIT LOCATION MAP …............................................

FIGURE 3 - CAU 400 FIVE POINTS LANDFILL LOCATION MAP ...................................

FIGURE 4 - CAU 404 ROLLER COASTER LAGOONS AND TRENCH LOCATION MAP. 


\section{TABLE OF CONTENTS (continued)}

\section{FIGURES (continued)}

FIGURE 5 - CAU 407 ROLLER COASTER RADSAFE AREA LOCATION MAP .13

FIGURE 6 - CAU 424 AREA 3 LANDFILL COMPLEXES LOCATION MAP. .15

FIGURE 7 - CAU 426 CACTUS SPRING WASTE TRENCHES LOCATION MAP. .21

FIGURE 8 - CAU 427 AREA 3 SEPTIC WASTE SYSTEMS 2 AND 6 LOCATION MAP .....23

FIGURE 9 - CAU 453 UXO LANDFILL LOCATION MAP .26

\section{ATTACHMENTS}

ATTACHMENT A - POST-CLOSURE INSPECTION PLANS

ATTACHMENT B - INSPECTION CHECKLISTS

ATTACHMENT C - FIELD NOTES

ATTACHMENT D - PHOTOGRAPHS

ATTACHMENT E - POST-CLOSURE VEGETATIVE MONITORING REPORT (SEPTEMBER, 2003)

ATTACHMENT F - SURVEY RESULTS FOR CAU 424 AND CAU 427

DISTRIBUTION LIST 
Tonopah Test Range

2003 Post-Closure Inspection Report

Revision: 0

Date: April 2004

THIS PAGE INTENTIONALLY LEFT BLANK 
Date: April 2004

\section{LIST OF ACRONYMS AND ABBREVIATIONS}

BN

$\mathrm{CADD} / \mathrm{CR}$

CAS

CAU

CR

$\mathrm{DOE} / \mathrm{NV}$

$\mathrm{ft}$

FY

$\mathrm{m}$

NDEP

ROTC

TTR
Bechtel Nevada

Corrective Action Decision Document/Closure Report

Corrective Action Site

Corrective Action Unit

Closure Report

U.S. Department of Energy, Nevada Operations Office

foot (feet)

Fiscal Year

meter(s)

Nevada Division of Environmental Protection

Record of Technical Change

Tonopah Test Range 
Tonopah Test Range

2003 Post-Closure Inspection Report

Revision: 0

Date: April 2004

THIS PAGE INTENTIONALLY LEFT BLANK 


\section{EXECUTIVE SUMMARY}

This Post-Closure Inspection Report provides documentation of the semiannual inspections conducted at the Tonopah Test Range during calendar year 2003. The report includes the inspection and/or repair activities completed at the following Corrective Action Units (CAUs): CAU 400: Bomblet Pit and Five Points Landfill (TTR); CAU 404: Roller Coaster Lagoons and Trench (TTR); CAU 407: Roller Coaster RadSafe Area (TTR); CAU 424: Area 3 Landfill Complexes (TTR); CAU 426: Cactus Spring Waste Trenches (TTR); CAU 427: Septic Waste Systems 2, 6 (TTR); CAU 453: Area 9 UXO Landfill (TTR), and CAU 487: Thunderwell Site (TTR), all located at the Tonopah Test Range, Nevada. Post-closure inspections are not required at CAU 400 but are conducted to monitor vegetation and fencing at the site. Post-closure inspections are not required at this time for CAU 487 but site information is included in this report because the Corrective Action Decision Document/Closure Report (CADD/CR) is being revised to include installation of monuments and inspections.

Site inspections were conducted on June 10,2003, and December 3, 2003. All site inspections were completed after Nevada Division of Environmental Protection (NDEP) approval of the appropriate Closure Report (CR), excluding CAU 400 which did not require a CR, and were conducted in accordance with the Post-Closure Inspection Plans in the NDEP-approved CRs.

Post-Closure inspections conducted during 2003 identified several areas requiring maintenance/repairs. CAU 400 was in good condition during both inspections and no maintenance or repairs were conducted. Minor erosion and sediment deposition along the Five Points Landfill fence was noted in the 2003 Post-Closure Vegetative Monitoring Report and was noted during the December 3, 2003 inspection. The CAU 400 Five Points Landfill will be evaluated in 2004 to determine if repairs are needed. CAU 404 was in good condition, vegetation was healthy, and several small animal burrows were repaired along the fencing at the time of site inspections. Although the site was in generally good condition several areas of erosion were present on the CAU 407 cover side slopes. The recommendation is made to repair the areas of erosion and apply seed and mulch to help stabilize the CAU 407 cover. All monuments and signage at CAU 424 were in good condition and maintenance was completed in 2003 to stamp land-use coordinates on each monument. Topographically low areas, possibly caused by subsidence, have been identified at closed landfill cells A3-1 and A3-4, and the recommendation is made to add fill to the low areas at CAU 424 to bring them to surrounding grade. An area of damaged fence was observed at CAU 426 during the first inspection in 2003 and was subsequently repaired. The site was in good condition during the second 2003 inspection. Three subsurface markers at CAU 427 could not be located during the first 2003 inspection and were thought possibly to have been removed during recently completed excavation in the immediate area. The subsurface markers were subsequently located and had been slightly buried. Maintenance was completed at CAU 427 to place an additional sign on an adjacent building and collect survey measurements to support future site inspections. CAU 427 was in good condition during the second 2003 inspection. CAU 453 was in good condition during both inspections; the fence and monuments were in good condition, no areas of subsidence were observed, and several small animal burrows were repaired along the fencing at the time of site inspections. The two land-use restriction warning signs at CAU 487 have been destroyed by horses. The $\mathrm{CADD} / \mathrm{CR}$ is being revised to include installation of concrete monuments and the requirement for Post-Closure inspections. 
This report includes copies of the Post-Closure Inspection Plans, Post-Closure Inspection Checklists, copies of field notes, photographs, the Post-Closure Vegetative Monitoring Report, and survey data. 


\subsection{INTRODUCTION}

This post-closure inspection report includes the results of inspection activities, maintenance and repair activities, and conclusions and recommendations for calendar year 2003 for eight corrective action units (CAUs) located on the Tonopah Test Range, Nevada. The. CAUs and Corrective Action Sites (CASs) included in the report include the following (Figure 1):

- $\quad$ CAU 400: Bomblet Pit and Five Points Landfill (TTR)

- CAS TA-19-001-05PT, Ordnance Disposal Pit

- CAS TA-55-001-TAB2, Ordnance Disposal Pit

- CAU 404: Roller Coaster Lagoons and Trench (TTR)

- CAS TA-03-001-TARC, Roller Coaster Lagoons

- CAS TA-21-001-TARC, Roller Coaster N. Disposal Trench

- CAU 407: Roller Coaster RadSafe Area (TTR)

- CAS TA-23-001-TARC, Roller Coaster RadSafe Area

- CAU 424: Area 3 Landfill Complexes (TTR)

- CAS 03-08-001-A301, Landfill Cell A3-1

- CAS 03-08-001-A302, Landfill Cell A3-2

- CAS 03-08-001-A303, Landfill Cell A3-3

- CAS 03-08-001-A304, Landfill Cell A3-4

- CAS 03-08-001-A305, Landfill Cell A3-5

- CAS 03-08-001-A306, Landfill Cell A3-6

- CAS 03-08-001-A307, Landfill Cell A3-7

- CAS 03-08-001-A308, Landfill Cell A3-8

- CAU 426: Cactus Spring Waste Trenches (TTR)

- CAS RG-08-001-RGCS, Waste Trenches

- CAU 427: Area 3 Septic Waste Systems 2, 6 (TTR)

- CAS 03-05-002-SW02, Septic Waste System

- CAS 03-05-002-SW06, Septic Waste System

- $\quad$ CAU 453: Area 9 UXO Landfill (TTR)

- CAS 09-55-001-0952, Area 9 Landfill

- $\quad$ CAU 487: Thunderwell Site (TTR)

- CAS RG-26-001-RGRV, Thunderwell Site

Post-closure inspections are completed on a bi-annual (twice per calendar year) basis and consist of the following activities to evaluate and document the condition of the closed unit (CAUspecific inspection requirements are presented in Attachment A):

- $\quad$ Site inspection and photo-documentation to verify site conditions and note variances from previous inspections;

- Inspection of fencing, signs, monuments, and/or markers to determine if repairs and/or maintenance are needed;

- Inspection of soil covers for indications of subsidence, erosion, unauthorized use, etc.;

- Vegetation survey to quantify the condition of vegetative covers;

- $\quad$ Preparation and submittal of an annual report.

While no specific post-closure inspection requirements exist for CAU 400, the Nevada Division of Environmental Protection (NDEP) has requested annual vegetation monitoring until the site 


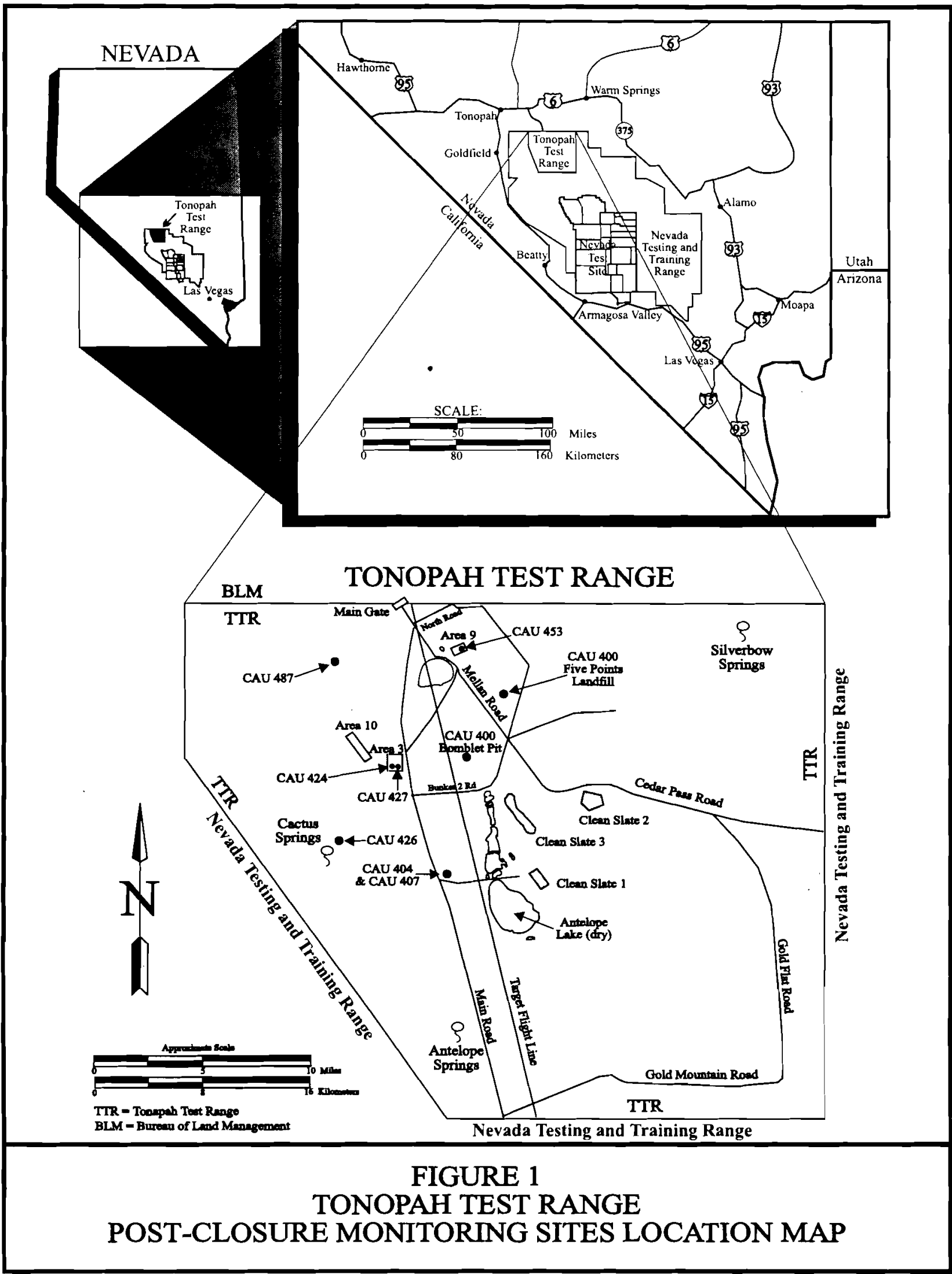


conditions are suitable to justify removal of the site fencing. Details are included within Section 2.1 of this report. CAU 487 (Thunderwell Site (TTR)) was closed under a Corrective Action Decision Document/Closure Report (CADD/CR) with no post-closure inspection requirements (DOE/NV, 2001b). Subsequent site visits and a review of the use restrictions have identified several errors and deficiencies that require correction. A record of technical change (ROTC) is currently in progress to modify the CADD/CR and use restrictions, and to include post-closure inspections. Details for CAU 487 are included within Section 2.8 of this report.

All site inspections were conducted in accordance with the Post-Closure Monitoring Plans in the appropriate NDEP approved Closure Report (CR) for each CAU, with the exception of CAU 400 , which did not require a CR. Attachment $A$ includes the post-closure inspection plan for each CAU. Post-Closure Inspection Checklists are located in Attachment B. Copies of the field notes from each inspection are included in Attachment $C$. Attachment D consists of the photographic logs and photographs of the sites. The post-closure vegetative monitoring report for calendar year 2003 is included in Attachment E. The results of subsidence and measurement surveys completed in 2003 are included in Attachment F, and the document distribution.

\subsection{CLOSURE REPORT CONTENTS}

This Post Closure Inspection Report is divided into the following sections:

- Section 1.0 - Introduction: Identification of CAU and CAS names and numbers, description of the general scope of inspections and maintenance work, and report contents.

- Section 2.0 - Post Closure Inspections: Inspection scope, first and second annual inspection results, maintenance and repairs, and conclusions and recommendations.

- Section 3.0 - Summary: Summary of the post-closure inspection and maintenance work completed during the calendar year.

- Section 4.0 - References

- Attachment A - Post-Closure Inspection Plans

- Attachment B - Inspection Checklists

- Attachment C - Field Notes

- Attachment D - Photographs

- Attachment E-Post-Closure Vegetate Monitoring Report

- Attachment F - 2003 Subsidence and Measurement Survey Results

- Distribution List 
Revision: 0

Date: April 2004

\section{THIS PAGE INTENTIONALLY LEFT BLANK}




\subsection{POST-CLOSURE INSPECTIONS}

\subsection{CAU 400 Bomblet Pit and 5 Points Landfill (TTR)}

\subsubsection{CAU 400 Introduction}

There are no specific post-closure monitoring requirements for CAU 400: Bomblet Pit and Five Points Landfill (TTR), as described in the Tonopah Test Range Closure Sites Revegetation Plan (U.S. Department of Energy, Nevada Operations Office [DOE/NV], 1997). However, as stated in section 3.5.4 of the Revegetation Plan, fencing is required at the Bomblet Pit (CAS TA-55-001-TAB2, Ordnance Disposal Pit) and the Five Points Landfill (CAS TA-19-001-05PT, Ordnance Disposal Pit) for a minimum of five years in order to give plants sufficient time to become established and able to withstand the effects of herbivory. Site visits and inspections are conducted at CAU 400 while completing post-closure monitoring at other sites on the Tonopah Test Range. Inspections are completed to collect photo-documentation of vegetation growth and inspect the integrity of the fence surrounding the site. Removal of the fence at the Bomblet Pit and 5 Points Landfill was proposed in the 2002 report (NNSA/NV, 2002). NDEP denied the request for fence removal at this time and requested that annual inspection and evaluation of site vegetation continue. Removal of the site fencing may be proposed in the future once vegetation on the cover is better established.

Site inspections were conducted on June 10, 2003 and December 3, 2003. The Post-Closure Inspection Checklists are located in Attachment B. Copies of the field notes from each inspection are included in Attachment C. Attachment D contains the photographic logs and photographs. In addition to the semiannual inspections, vegetative monitoring of the site (a plant census) was conducted in September of 2003. The results are included in Appendix E.

\subsubsection{Inspection Results}

\subsubsection{CAU 400 First Semiannual Inspection}

\section{Bomblet Pit}

The first semiannual inspection of 2003 at the Bomblet Pit (Figure 2) was completed on June 10 , 2003. Numerous bomblets and bomblet fragments were noted during the site inspection, both inside and outside the fenced area. Several small animal burrows were identified along the fence line. No erosion, subsidence, or cracking of the surface was observed. The vegetation inside the fenced area appeared healthy, but slightly less dense than that present outside of the fence line. The majority of the species located in the fenced area appeared native; no thistle was present. Overall, the fencing and the area inside the fence appeared to be in good condition.

\section{Five Points Landfill}

The first semiannual inspection of 2003 at the Five Points Landfill (Figure 3) was completed on June 10,2003. Several small animal burrows were observed along the fence line along with some loose debris. There was very little debris located inside the fenced area, and the burrows did not affect the integrity of the unit. No erosion, subsidence, or cracking of the cover surface was observed. The vegetation inside the fence appeared healthy and plentiful, with some Russian Thistle present. Overall, the fencing and the area inside the fence were observed to be in good condition. 


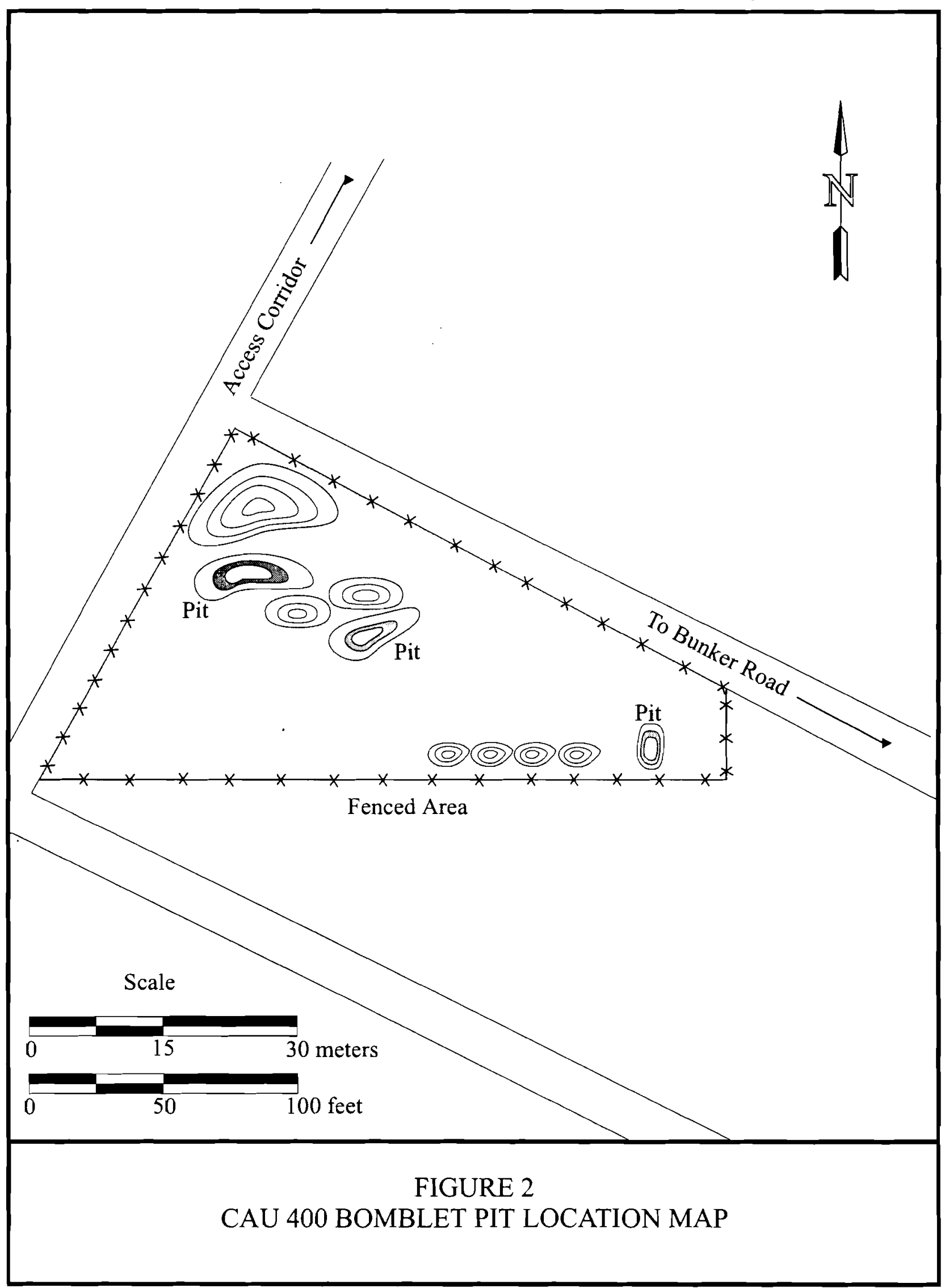




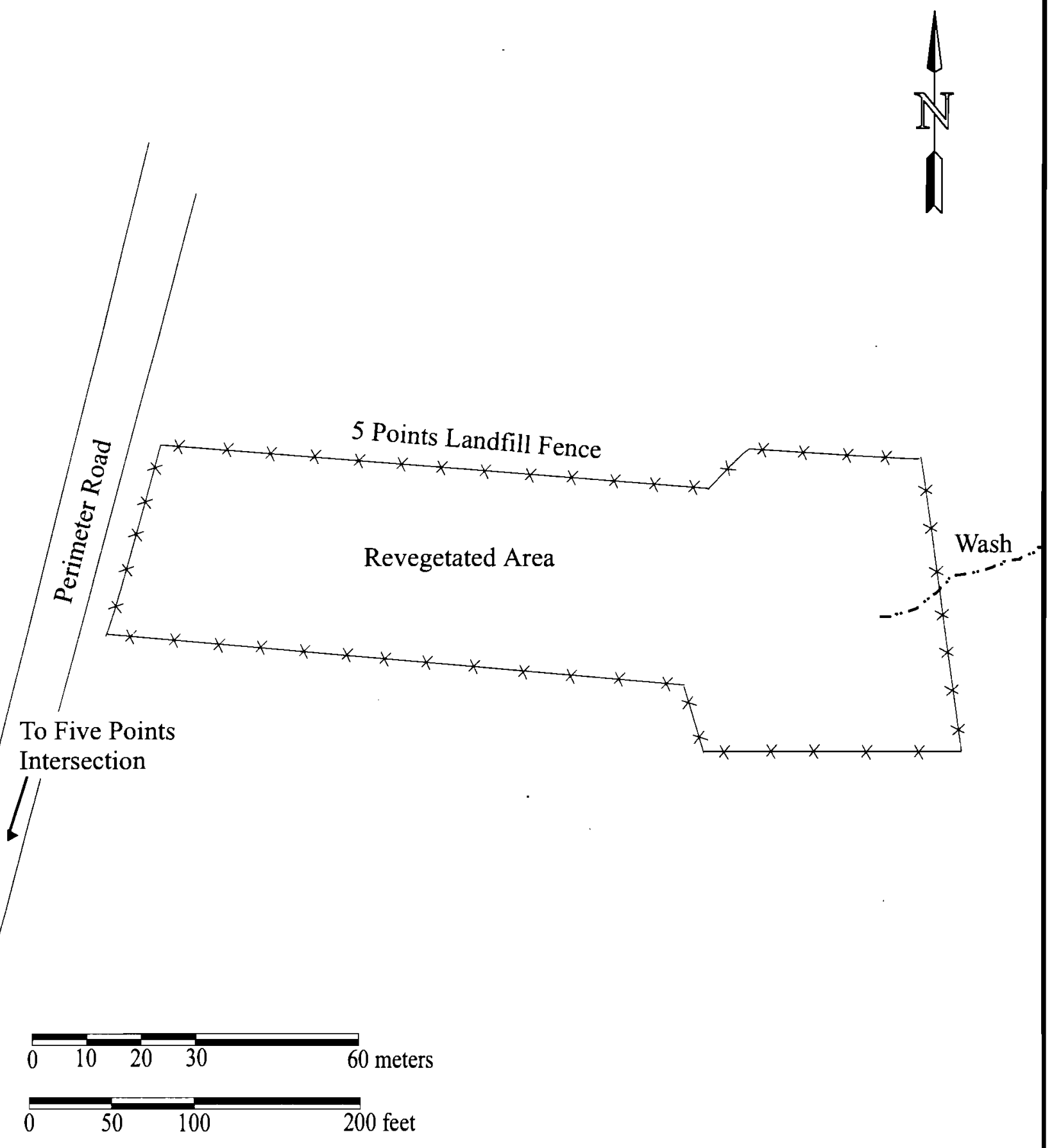

FIGURE 3

CAU 4005 POINTS LANDFILL LOCATION MAP 


\subsubsection{CAU 400 Second Semiannual Inspection}

\section{Bomblet Pit}

The second semiannual inspection of 2003, for the Bomblet Pit, was completed on December 3, 2003. A small number of animal burrows and evidence of animal activity along the fence perimeter were noted during the inspection. The vegetation on the cover and inside the fenced area was healthy and well established. Numerous bomblets and bomblet fragments were noted during the site inspection, both inside and outside the fenced area. One fragment of some type of ordnance with fuze attached was present at the northwest corner of the site fence. It could not be determined if the fuze was live. The overall condition of the site was good, with no evidence of settling or cracking on the cover.

\section{Five Points Landfill}

The second semiannual inspection of 2003, for the Five Points Landfill, was completed on December 3, 2003. A small number of animal burrows and evidence of animal activity along the fence perimeter were noted during the inspection. The vegetation on the cover and inside the fenced area was well established and healthy. The overall condition of the site was good, with no evidence of settling or cracking on the cover. Some minor erosion was present in the center of the site along surface water channels. The central portion of the site was also covered by dried sediment apparently from standing water. A portion of the fence along the east side of the site was partially covered with sediment and debris which had accumulated from recent storm events. This site should be evaluated during 2004 to determine if maintenance and/or repairs are needed. Conditions were consistent with those observed during 2003 vegetative monitoring.

\subsubsection{CAU 400 Maintenance and Repairs}

The only maintenance and repairs conducted at the site during this reporting period occurred concurrently with the first semiannual inspection. Several small animal burrows along the fence line were backfilled at the Bomblet Pit and the Five Points Landfill. In addition, several pieces of surface debris were removed from outside and inside the fenced area at the Five Points Landfill.

\subsubsection{CAU 400 Conclusions and Recommendations}

Small animal burrows were present along the fence line of both sites, but did not appear to affect the integrity of the covers. The condition of the covers was good, with healthy and well established plant species growing within the fenced areas. At the Bomblet Pit, numerous bomblets and bomblet fragments were noted during the site inspection, inside and outside the fenced area. The overall condition of both sites was good, with no evidence of settling or cracking on the cover. The need for maintenance and/or repairs due to standing water at the Five Points Landfill should be evaluated during the next site inspections completed in Spring 2004.

As stated in section 3.5.4 of the NDEP-approved Revegetation Plan (DOE/NV, 1997), the fencing requirement for the Bomblet Pit and the Five-Points Landfill is that both sites be fenced for a minimum of five years in order to give plants sufficient time to become established and able to withstand the effects of herbivory. Based on the results of recent semiannual inspections and a plant census conducted at both sites in September of 2003 (Appendix E), it has been determined that the vegetation inside the fenced areas is not sufficiently established. It is recommended that both sites remain fenced and annual site inspections continue. Removal of 
the fencing will be proposed in the future when site conditions indicate the vegetation has matured to the same extent as the surrounding areas.

\subsection{CAU 404 Roller Coaster Lagoons and Trench (TTR)}

\subsubsection{CAU 404 Introduction}

CAU 404 consists of two CASs, CAS TA-03-001-TARC, Roller Coaster Lagoons, and CAS TA-21-001-TARC, Roller Coaster North Disposal Trench. Post-closure monitoring requirements for CAU 404 are described in the CR for CAU 404: Roller Coaster Sewage Lagoons and North Disposal Trench (TTR) (DOE/NV, 1998a). The CR was submitted to the NDEP on September 11, 1998. Permeability results of soils adjacent to the engineered cover and a request for closure of CAU 404 were transmitted to the NDEP on April 29, 1999. The CR (containing the Post-Closure Monitoring Plan) was approved by the NDEP on May 18, 1999.

As stated in Section 5.0 of the NDEP-approved CR (DOE/NV, 1998a), post-closure monitoring at CAU 404 consists of the following:

- Visual site inspections conducted twice a year to evaluate the condition of the cover and plant development.

- $\quad$ Additional, non-scheduled inspections may be required after severe weather events.

- Verification that the site is secure and that the fence and posted warning signs are in good condition.

- $\quad$ Notice of any subsidence, erosion, unauthorized excavation, and other deficiencies that may compromise the integrity of the unit.

- Remedy of any deficiencies within 90 days of discovery.

- $\quad$ Preparation and submittal of an annual report.

Site inspections were conducted on June 10, 2003, and December 3, 2003. A diagram showing the site location and configuration is presented in Figure 4. The site inspections were conducted in accordance with the Post-Closure Monitoring Plan (Attachment A) in the NDEP-approved CR (DOE/NV, 1998a). The Post-Closure Inspection Checklists are located in Attachment B. Copies of the field notes from each inspection are included as Attachment C. Attachment D consists of the photographic logs and photographs.

In addition to the semiannual inspections, vegetative monitoring of the site (a plant census) was conducted in September of 2003. The results are included in Attachment E.

\subsubsection{CAU 404 Inspection Results}

\subsubsection{CAU 404 First Semiannual Inspection}

The first semiannual inspection of 2003 was completed on June 10, 2003. Several small animal burrows were observed along the fence line and on the side of the cover. The burrows did not affect the integrity of the unit. The wire fence and the chicken wire mesh fence were in good condition, with no apparent holes or breaches in the fencing. All seven signs at the site were legible. No erosion, subsidence, or cracking of the cover surface was observed. The 


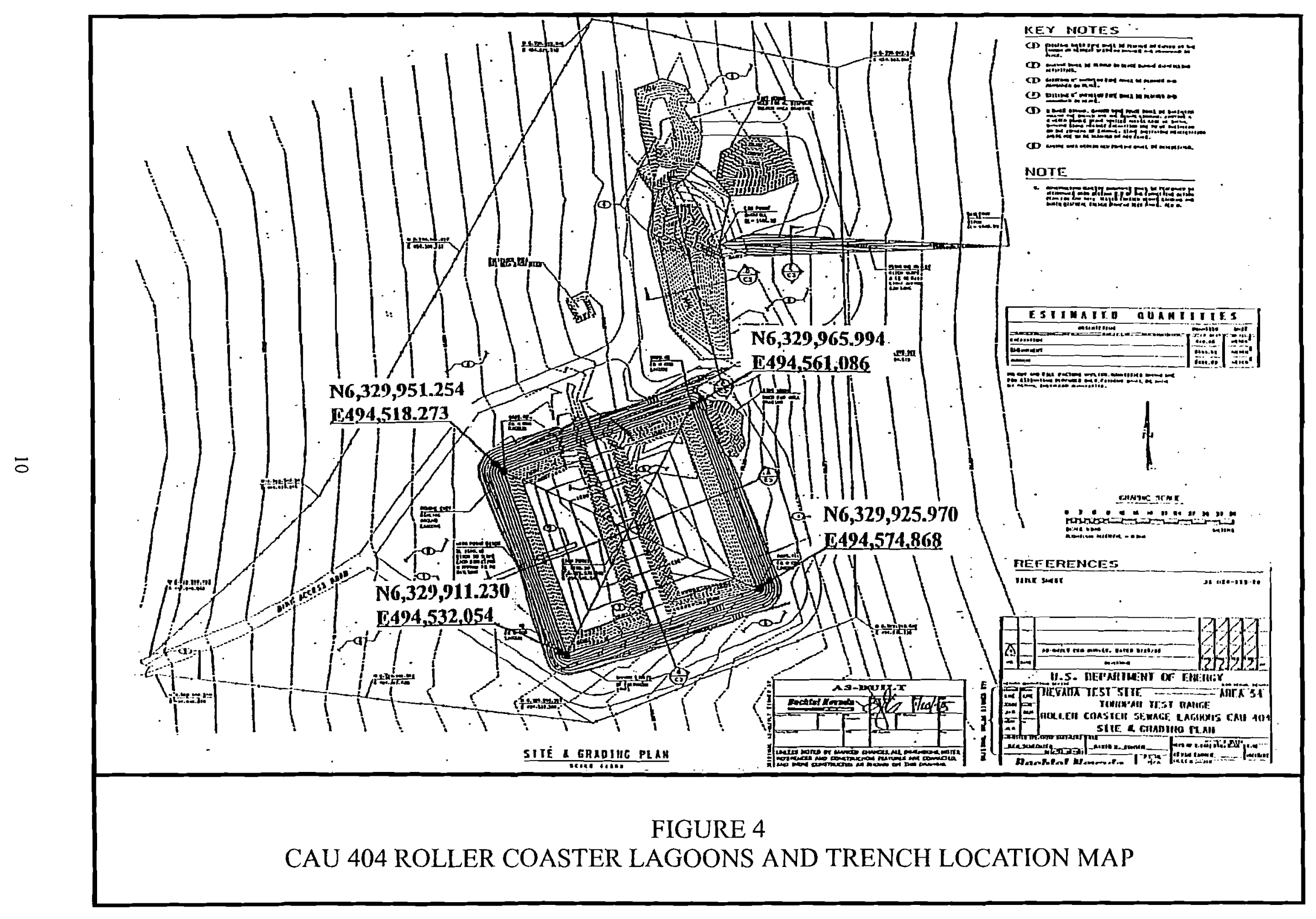


vegetation inside the fence and on the cover was sparse, but appeared to be healthy. Overall, the cover, fencing, and the area inside the fence were observed to be stable and in good condition.

\subsubsection{CAU 404 Second Semiannual Inspection}

The second semiannual inspection of 2003 was completed on December 3, 2003. A small number of animal burrows and evidence of animal activity along the fence line were noted during the inspection. The wire fence, chicken wire mesh, and gates were all in good condition. All seven signs were legible and securely fastened to the fence. The vegetation on the cover and inside the fenced area was well established and healthy. There was no evidence of erosion, settling, or cracking on the cover. The integrity of the cover unit was good.

\subsubsection{CAU 404 Maintenance and Repairs}

Maintenance and repairs at CAU 404 were very minimal and consisted of minor backfilling of several small animal burrows along the fence line at the time of inspection.

\subsubsection{CAU 404 Conclusions and Recommendations}

The overland runoff was being properly diverted around the site. There was no evidence of drainage or erosion through the site. The condition of the cover was good, with a good diversity of plant species growing on the cover and within the fenced area. A detailed plant census at CAU 404 was conducted in September of 2003, and the results are included in Attachment E. Overall, the cover area, fencing, posted warning signs, and gates were all in good condition. No further maintenance or repairs to the site are recommended at this time. It is also recommended that the frequency of site inspections remains the same, except in the event of severe weather, where a nonscheduled site inspection may be required.

\subsection{CAU 407 Roller Coaster RadSafe Area (TTR)}

\subsubsection{CAU 407 Introduction}

Post-Closure monitoring requirements for CAU 407 (CAS TA-23-001-TARC), Roller Coaster RadSafe Area) are described in the CR for CAU 407: Roller Coaster RadSafe Area (TTR) (DOE/NV, 2001a). The CR was submitted to the NDEP on April 24, 2001. No issues with the post-closure monitoring plan, Section 5.0, were raised. However, other concerns raised by stakeholders required that the CR be revised. Revision 1 of CR was issued in December of 2001 and was approved by NDEP on February 22, 2002. Section 5.2 of the NDEP-approved CR calls for site inspections to be conducted within the first six months following completion of cover construction (DOE/NV, 2001a). Following the first six months, site inspections are to be conducted twice yearly for the next two years. Previous inspections have noted areas of erosion on the cover and cover margins, and subsequent maintenance was completed to repair the erosion and prevent future erosion. Inspections should continue until the site has stabilized and erosion is no longer an ongoing issue. 
As stated in Section 5.2 of the CR (DOE/NV, 2001a), post-closure site inspections at CAU 407 consist of the following:

- Visual site inspections conducted twice a year to evaluate the condition of the cover and plant development.

- Verification that the site is secure and that the fence and posted warning signs are in good condition.

- Notice of any subsidence, erosion, unauthorized excavation, and other deficiencies that may compromise the integrity of the unit.

- Remedy of any deficiencies within 90 days of discovery.

- Preparation and submittal of an annual report.

Site inspections were conducted on June 10, 2003, and December 3, 2003. A diagram showing the site location and configuration can be seen in Figure 5. The site inspections were conducted in accordance with the Post-Closure Monitoring Plan (Attachment A) in the NDEP-approved CR (DOE/NV, 2001a). The Post-Closure Inspection Checklists are located in Attachment B. Copies of the field notes from each inspection are included as Attachment C. Attachment D consists of the photographic logs and photographs.

\subsubsection{CAU 407 Inspection Results}

\subsubsection{CAU 407 First Semiannual Inspection}

The first semiannual post-closure inspection for 2003 of CAU 407 was completed on June 10 , 2003. The fence is a three-strand barbed-wire fence; no chicken wire mesh is present to prevent small animals from entering the fenced area. The fence was in good condition, with no apparent holes or breaches in the fencing; however a fence post in the southeast corner of the site fencing was loose in the ground. The underground radioactive material warning signs posted along the fence line were beginning to fade; however, their condition was good and readable. Minor erosion rills in the south and east cover side slopes were noted; however, they were not significant enough to impact the cover integrity. Overall, the cover, fencing, warning signs, and the area inside the fence appeared to be stable and in good condition. Fencing repair and replacement of faded radiological postings was noted to be completed during future repair activities.

\subsubsection{CAU 407 Second Semiannual Inspection}

The second semiannual post-closure inspection for 2003 of CAU 407 was completed on December 3, 2003. The fencing and signage were in good condition. Evidence of animal activity was observed outside of the fence line. The minor erosion rills on the cover and cover slopes observed during the June 10, 2003, inspection had been repaired on July 16, 2003. Additional areas of erosion were observed to be developing on the cover and side slopes. Several of the erosional rills appeared to be several inches or more deep but did not appear to impact the cover integrity. There were no signs of subsidence on the cover. No vegetation is present on the cover. 


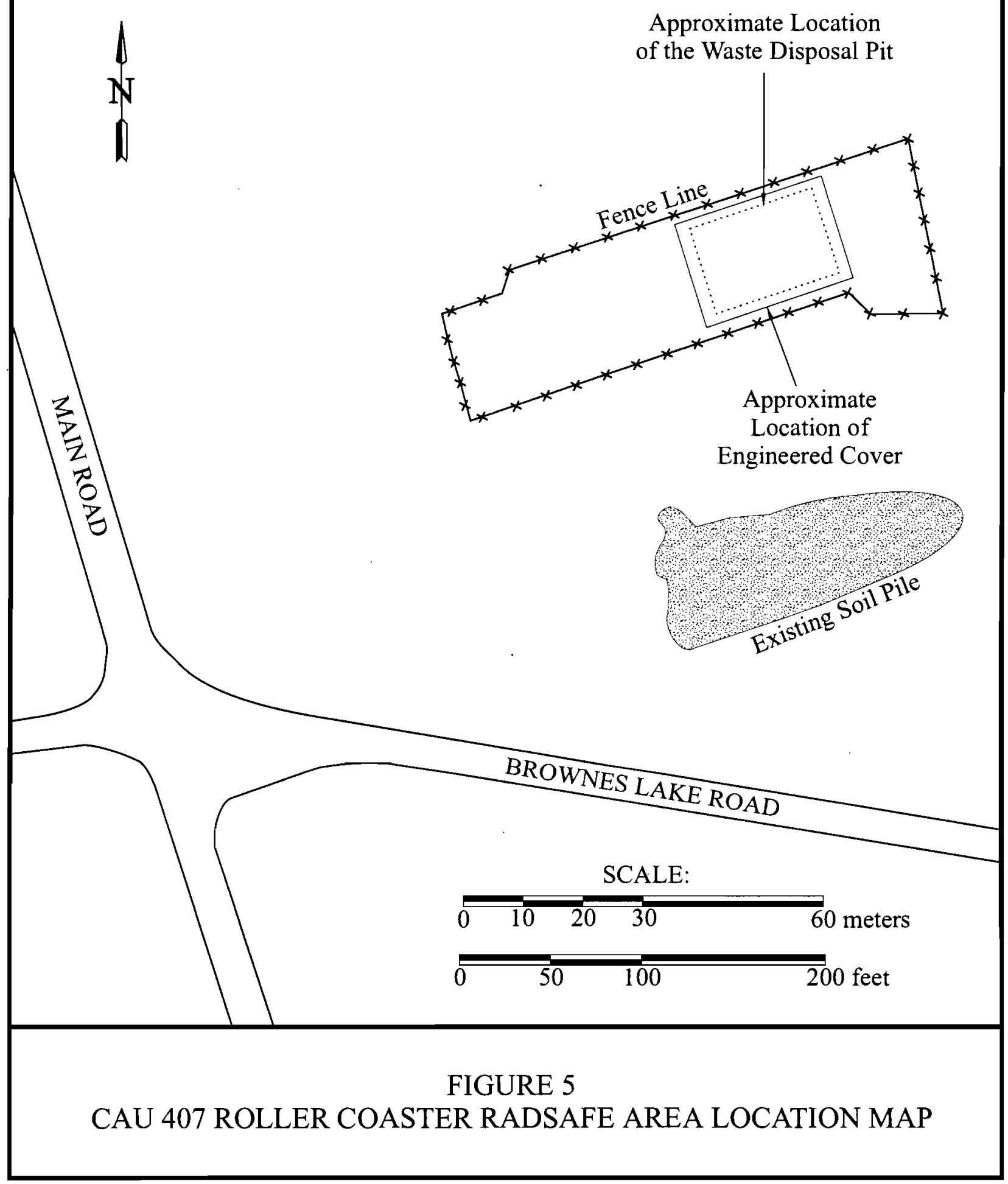




\subsubsection{CAU 407 Maintenance and Repairs}

Repair activities for CAU 407 consisted of fence and minor cover repair completed on July 16 , 2003. The southeast corner fence post was repaired and the attached fencing tension was tightened. Additional clean fill was added to repair the areas of erosion on the cover side slopes, and faded radiological posting signs were replaced with new signs.

\subsubsection{CAU 407 Conclusions and Recommendations}

The cover remains in good condition although minor erosion continues to develop on the side slopes due to precipitation run-off and the sparseness of vegetation on the cover. A detailed plant census at CAU 407 was conducted in September of 2003, and the results are included in Attachment E. The fencing and signage were in good condition. No indications of subsidence appeared on the cover. No other repairs to the cover or changes in the frequency of site inspections are recommended at this time

Reparing areas of erosion on the cover, and seeding and mulching of the cover is proposed. Establishing vegetation on the cover will facilitate stabilization of the side slopes and will mitigate the effects of stormwater runoff on the soil cover at the site. Substantial storm events may continue to degrade the cover conditions even with the addition of vegetation.

\subsection{CAU 424 Area 3 Landfill Complexes (TTR)}

\subsubsection{CAU 424 Introduction}

CAU 424: Area 3 Landfill Complexes (TTR), consists of eight Corrective Action Sites (CASs). Seven landfill cells (CAS 03-08-001-A301, Landfill Cell A3-1; CAS 03-08-001-A302, Landfill Cell A3-2; CAS 03-08-001-A303, Landfill Cell A3-3; CAS 03-08-001-A304, Landfill Cell A34; CAS 03-08-005-A305, Landfill Cell A3-5; CAS 03-08-001-A306, Landfill Cell A3-6; and CAS 03-08-001-A308, Landfill Cell A3-8 were previously closed by soil covers. The eighth CAS, 03-08-001-A307, Landfill Cell A3-7, was not used as a landfill site and was closed without taking any corrective action. CAU 424 closure activities included removing small volumes of soil containing petroleum hydrocarbons, repairing cell covers that were cracked or had subsided, and installing above-grade and at-grade monuments to mark the corners of the landfill cells. Post-closure monitoring requirements for CAU 424 are detailed in Section 5.0, Post-Closure Inspection Plan, contained in the CR for CAU 424, Area 3 Landfill Complexes (TTR) (DOE/NV, 1999a). The CR was approved by the NDEP in July 1999. The CR includes compaction and permeability data for soils that cap the seven landfill cells.

As stated in Section 5.0 of the NDEP-approved CR (DOE/NV, 1999a), post-closure monitoring at CAU 424 consists of the following:

- $\quad$ Site inspections conducted twice a year to evaluate the condition of the unit.

- Additional, non-scheduled inspections, may be required after severe weather events.

- Verification that landfill markers and warning signs are in place, intact, and readable.

- $\quad$ Notice of any subsidence, erosion, unauthorized use, or deficiencies that may compromise the integrity of the landfill covers.

- Remedy of any deficiencies within 90 days of discovery.

- Preparation and submittal of an annual report. 
Date: April 2004

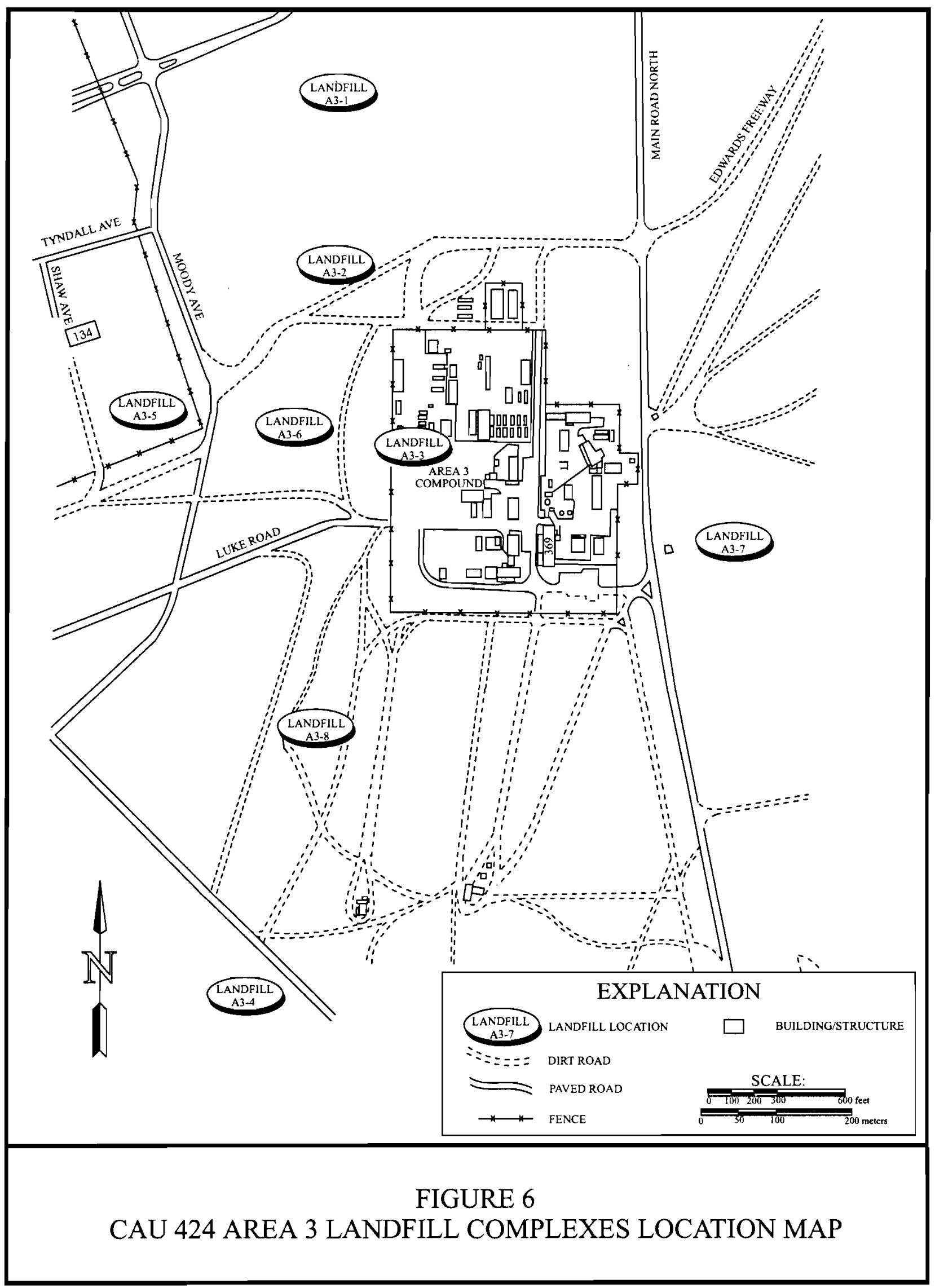


Site inspections were conducted on June 10, 2003, and December 3, 2003. A diagram showing the location of each of the landfills is presented as Figure 6. The site inspections were conducted in accordance with the Post-Closure Monitoring Plan (Attachment A) in the NDEP-approved CR (DOE/NV, 1999a). The Post-Closure Inspection Checklists are located in Attachment B. Copies of the field notes from each inspection are included as Attachment C. Attachment D consists of the photographic logs and photographs. The results of subsidence surveys completed in July 2003 are included in Attachment F.

\subsubsection{CAU 424 Inspection Results}

\subsubsection{CAU 424 First Semiannual Inspection}

The first inspection of CAU 424 was conducted on June 10, 2003.

Landfill Cell A3-1 (CAS 03-08-001-A301): Landfill Cell A3-1 is located at the north end of CAU 424 and is the largest of the landfill cells. The cover and the seven above-grade concrete monuments that demarcate the landfill cell were examined. All monuments, attached signs, and survey markers capping the monuments were legible and in good condition. No coordinates were stamped on the monuments. No evidence of cracking or erosion of the landfill cover was observed. An area of potential minor subsidence was noted in northeastern portion of the cover where the ground surface appears to be topographically lower than the surrounding area. Several small and shallow animal burrows were noted in the cover and were backfilled during the inspection. Neither the potential minor subsidence nor animal burrows effected the cover integrity. Vegetation was present on the cover, but sparse compared to surrounding undisturbed areas. The site was in overall good condition.

Landfill Cell A3-2 (CAS 03-08-002-A302): Landfill Cell A3-2 is located due south of Landfill Cell A3-1. Four above-grade monuments and the landfill cover were examined. All monuments, attached signs, and survey markers capping the monuments were legible and in good condition. No coordinates were stamped on the monuments. No evidence of subsidence, cracking, or erosion of the landfill cover was observed. Vegetation was present and healthy, but sparse compared to the surrounding undisturbed area. The site was in overall good condition.

Landfill Cell A3-3 (CAS 03-08-002-A303): Landfill Cell A3-3 straddles the western fence line of the Sandia National Laboratories Area 3 Compound, with parts of the landfill outside the fence marked by above-grade monuments and parts inside the fence marked by at-grade monuments. Three above-grade monuments marking the western edge of the landfill cell located outside the fence were examined. The three above-grade monuments, attached signs, and brass survey markers were legible and in good condition. Three at-grade monuments with brass markers defining the eastern edge of the landfill were visually located inside the Area 3 fence line and were determined to be in good condition. An excavation associated with closure activities of CAU 410 (Waste Disposal Trenches) was present immediately adjacent to the northern at-grade monument within the Area 3 compound (see Attachment D, photo 17). Although the excavation was within one foot of the monument, the integrity of the monument was not compromised. The area outside the fence was covered by sparse vegetation. The area inside the fence is heavily trafficked and bare of vegetation. No coordinates were stamped on any of the monuments. The site was in overall good condition. 
A small triangular-shaped second waste cell measuring approximately 3 by 3 by 3 meters (m) ( 10 by 10 by 10 feet [ft]), located immediately east of the dirt access road to the Bechtel Nevada (BN) Field Office (Building 03-78), was inspected. The cell is in a high-traffic area and the three at-grade brass makers were located and determined to be in good condition. The covers over both areas of the A3-3 landfill were in good shape with no signs of cracking, subsidence, or erosion.

Landfill Cell A3-4 (CAS 03-08-002-A304): Landfill Cell A3-4 is located south of Dykes Drive at the south end of the CAU. Five above-grade monuments and one at-grade brass marker were located. All monuments, markers, attached signs, and survey markers were legible and in good condition. No coordinates were stamped on the monuments. Vegetation was sparse but well established on the cover. A small area of the cover in the south end of the landfill appeared to be topographically lower than the surrounding area. The site was in overall good condition.

Landfill Cell A3-5 (CAS 03-08-002-A305): Landfill Cell A3-5 is located west of Moody Avenue inside a fenced area of Area 10 south of the Air Force First-Aid Station. All four abovegrade monuments with attached warning signs and survey markers were located and found to be legible and in good condition. There are no coordinates stamped on the monuments. The cover area was vegetated with Russian Thistle and sparse grasses. No evidence of cover subsidence, cracking, or erosion was observed. The site was in overall good condition.

Landfill Cell A3-6 (CAS 03-08-002-A306): Landfill Cell A3-6 is located immediately west of and outside the fence line of the Area 3 Compound. All four above-grade monuments with attached warning signs and brass survey markers were located and found to be in good condition. No coordinates were stamped on the monuments. Vegetation on the landfill was healthy and well established. No evidence of cover subsidence or erosion was observed. The site was in overall good condition.

Landfill Cell A3-8 (CAS 03-08-002-A308): Landfill Cell A3-8 is located southwest of the Area 3 Compound in the box car storage yard. Three of the four at-grade brass marker markers were located and were determined to be in good condition; however no coordinates were stamped on the monuments. The area was not vegetated due to heavy traffic. No evidence of subsidence or erosion to the cover was observed. The at-grade monument defining the southwest corner of the site was removed in 2002 during corrective actions at CAU 490 (Station 44 Burn Area). This monument was not present at the time of the first semiannual inspection but was scheduled for replacement in July 2003. The site was in overall good condition.

\subsubsection{CAU 424 Second Semiannual Inspection}

The second inspection of CAU 424 was conducted on December 3, 2003.

Landfill Cell A3-1 (CAS 03-08-001-A301): All seven above-grade monuments were located. All monuments, attached signs, and survey markers capping the monuments were legible and in good condition. Vegetation on the cover was sparse compared to surrounding undisturbed areas, but appears healthy and well established. A topographically low area is present in the northeast portion of the site. This condition was confirmed by survey data collected in July 2003. No cracking or erosion of the cover was observed. Land-use coordinates were present on all monument brass survey markers. The overall condition of the cover remains good. 
Landfill Cell A3-2 (CAS 03-08-002-A302): All four above-grade monuments were located. All monuments, attached warning signs, and stamped brass survey markers were in good condition. Sparse vegetation was present on the cover. No evidence of cover subsidence, cracking, or erosion was observed. Land-use coordinates were present on all monument brass survey markers. The overall condition of the cover was good.

Landfill Cell A3-3 (CAS 03-08-002-A303): All three above-grade monuments and three atgrade brass marker markers defining the west boundaries of the landfill were located and determined to be in good condition. All monuments, marker markers, attached warning signs, and stamped brass survey markers were in good condition. Three at-grade monuments within the Area 3 compound fence line were located and determined to be in good condition. The excavation associated with CAU 410 closure activities was backfilled prior to the December 03 , 2003, post-closure inspection. The at-grade monument adjacent to the excavation was in good condition and had not been damaged by excavation activities (see Attachment D, photo 18). Vegetation outside the Area 3 fence appeared healthy and well established, while the area inside the fence was not vegetated due to traffic. No signs of erosion or subsidence were observed. Land-use coordinates were present on all monument brass survey markers. The overall condition of the landfill cover was good.

A small triangular-shaped second waste cell approximately 3 by 3 by $3 \mathrm{~m}$ ( 10 by 10 by $10 \mathrm{ft}$ ), located immediately east of the dirt access road to the BN Field Office (Building 03-78), was inspected. The cell is in a high-traffic area and the three at-grade brass makers were located and determined to be in good condition. At-grade monuments are surrounded by red rock to aid in the visual location of the monuments. Land-use coordinates were present on all monument brass survey markers. The cover over each of the three cells was in good shape, with no signs of cracking, subsidence, or erosion.

Landfill Cell A3-4 (CAS 03-08-002-A304): Five above-grade monuments and one at-grade monument and brass survey marker were located and inspected. All monuments, attached warning signs, and survey markers were in good condition. Vegetation was sparse compared to adjacent undisturbed areas, but healthy and well established. No cracking or erosion was observed on the cover. However, an area of topographically low ground is present in the south portion of the landfill cell cover. This was confirmed by a survey completed in July 2003 . Land-use coordinates were present on all monument brass survey markers. The cover condition remains in good shape.

Landfill Cell A3-5 (CAS 03-08-002-A305): All four above-grade monuments were located. All monuments, attached signs, and survey markers were in good condition. No evidence of cover subsidence, cracking, or erosion was observed. Land-use coordinates were present on all monument brass survey markers. The overall condition of the landfil] cover was good.

Landfill Cell A3-6 (CAS 03-08-002-A306): All four above-grade monuments were located. All monuments, attached warning signs, and survey markers were in good condition. Vegetation on the landfill remains healthy and well established. No evidence of cover subsidence, cracking, or erosion was observed. Land-use coordinates were present on all monument brass survey markers. The overall condition of the landfill cover was good.

Landfill Cell A3-8 (CAS 03-08-002-A308): Four at-grade monuments and brass survey markers were found to be in good condition. The southwest corner monument removed during 
closure activities for CAU 490 was replaced during July 2003. The southern portion of the site is now included within a newly marked radioactive material area. The landfill cover is not vegetated because it is in a traffic area. No evidence of subsidence, cracking, or erosion was noted. Land-use coordinates were present on all monument brass survey markers. The overall condition of the cover remains good.

\subsubsection{CAU 424 Maintenance and Repairs}

Land-use restriction coordinates were stamped on all above-grade and at-grade monuments on July 09, 2003 (see Attachment D, photo 29 and photo 30). Coordinates stamped on the monuments were verified against the recorded land-use restriction coordinates in the CR to ensure accuracy (DOE/NV, 1999a).

Elevation profiles were surveyed at landfill cell A3-1 and landfill cell A3-4. Elevation data were used to prepare elevation contour maps for both sites (see Attachment F). The elevation data, contour map, and topographic profile for landfill cell A3-1 confirms that a topographically low area is present in the northeast portion of the site. The data indicate the northeast and eastern portions of the site are approximately 0.8 feet lower than the surrounding area outside of the landfill cell. This depression corresponds to a surface depression and "newly-buried construction debris" present during closure activities (see Attachment D, Figure 3 from the CAU 424 CR [DOE/NV, 1999a]).

The elevation data, contour map, and topographic profile for landfill cell A3-4 confirm that a north-south trending topographically low area is present in the south and central area of the site. The data indicate that the southern portion of the site is approximately 0.6 feet lower than the surrounding area outside of the landfill cell. The topographically low areas appear to correspond to locations of shallow fill not tested during closure activities (see Attachment D, Figure 5 from the CAU $424 \mathrm{CR}$ [DOE/NV, 1999a]). The topographically low areas should be filled to the level of the surrounding grade to prevent infiltration of standing water into the buried waste unit.

\subsubsection{CAU 424 Conclusions and Recommendations}

All CAU 424 closed landfill cells are in generally good condition. The only maintenance and/or repair activity recommended for the $\mathrm{CAU}$ is the addition of clean fill to topographically low areas in landfill cells A3-1 and A3-4 to the approximate surrounding grade. A post-repair elevation survey should be completed to verify suitable grade has been obtained. The current inspection schedule should be maintained.

\subsection{CAU 426 Cactus Spring Waste Trenches (TTR)}

\subsubsection{CAU 426 Introduction}

Post-closure monitoring requirements for CAU 426 (CAS RG-08-001-RGCS, Waste Trenches) are described in the CR for CAU 426: Cactus Spring Waste Trenches (TTR) (DOE/NV, 1998b). The CR was submitted to the NDEP on August 14, 1998. Permeability data for soils adjacent to the engineered cover and a request for closure of CAU 426 were transmitted to the NDEP on April 29, 1999. The CR (containing the Post-Closure Monitoring Plan) was approved by the NDEP on May 13, 1999. 
As stated in Section 5.0 of the NDEP-approved CR, Post-Closure Monitoring Plan (DOE/NV, 1998b), site monitoring at CAU 426 consists of the following:

- Visual site inspections conducted twice a year to evaluate the condition of the cover and plant development.

- Additional, nonscheduled inspections, may be required after severe weather events.

- Verification that the site is secure and that the fence and posted warning signs are in good condition.

- Notice of any subsidence, erosion, unauthorized excavation, or other deficiencies that may compromise the integrity of the unit.

- $\quad$ Remedy of any deficiencies within 90 days of discovery.

- Preparation and submittal of an annual report.

Site inspections were conducted on June 10, 2003, and December 3,2003. A diagram showing the site location and configuration are shown in Figure 7. The site inspections were conducted in accordance with the Post-Closure Monitoring Plan (Attachment A) in the NDEP-approved CR (DOE/NV , 1998b). The Post-Closure Inspection Checklists are located in Attachment B.

Copies of the field notes from each inspection are included as Attachment C. Attachment D consists of the photographic logs and photographs. In addition to the semiannual inspections, vegetative monitoring of the site (a plant census) was conducted in September of 2003. The results are included in Attachment $\mathrm{E}$.

\subsubsection{CAU 426 Inspection Results}

\subsubsection{CAU 426 First Semiannual Inspection}

The first inspection for 2003 was completed on June 10, 2003. The gate and posted warning signs were in good condition. Two areas of the south portion of site fencing had been damaged by wild horses (see Attachment D, photograph 31). Two sections of the fence had broken wire and bent fence posts. Small animal burrows were present along the fence line. The vegetation on the cover and in the staging area inside the fence appeared sparse but healthy. No evidence of erosion, cracking, or subsidence on the cover was observed.

\subsubsection{CAU 426 Second Semiannual Inspection}

The second inspection for 2003 was completed on December 3, 2003. Damaged fencing noted during the first semiannual. inspection had been repaired and the fence, gate, and signage were in good condition. Some animal burrows were present along the fence line and Russian Thistle (tumbleweeds) were present inside the fenced area. The cover showed no signs of erosion, cracking, or subsidence. Vegetation on the cover and within the fence line was in good condition.

\subsubsection{CAU 426 Maintenance and Repairs}

Small burrows along the fence line were backfilled during the June and December 2003 inspections. On July 16, 2003, the two areas damaged on the south fence line by horses were 


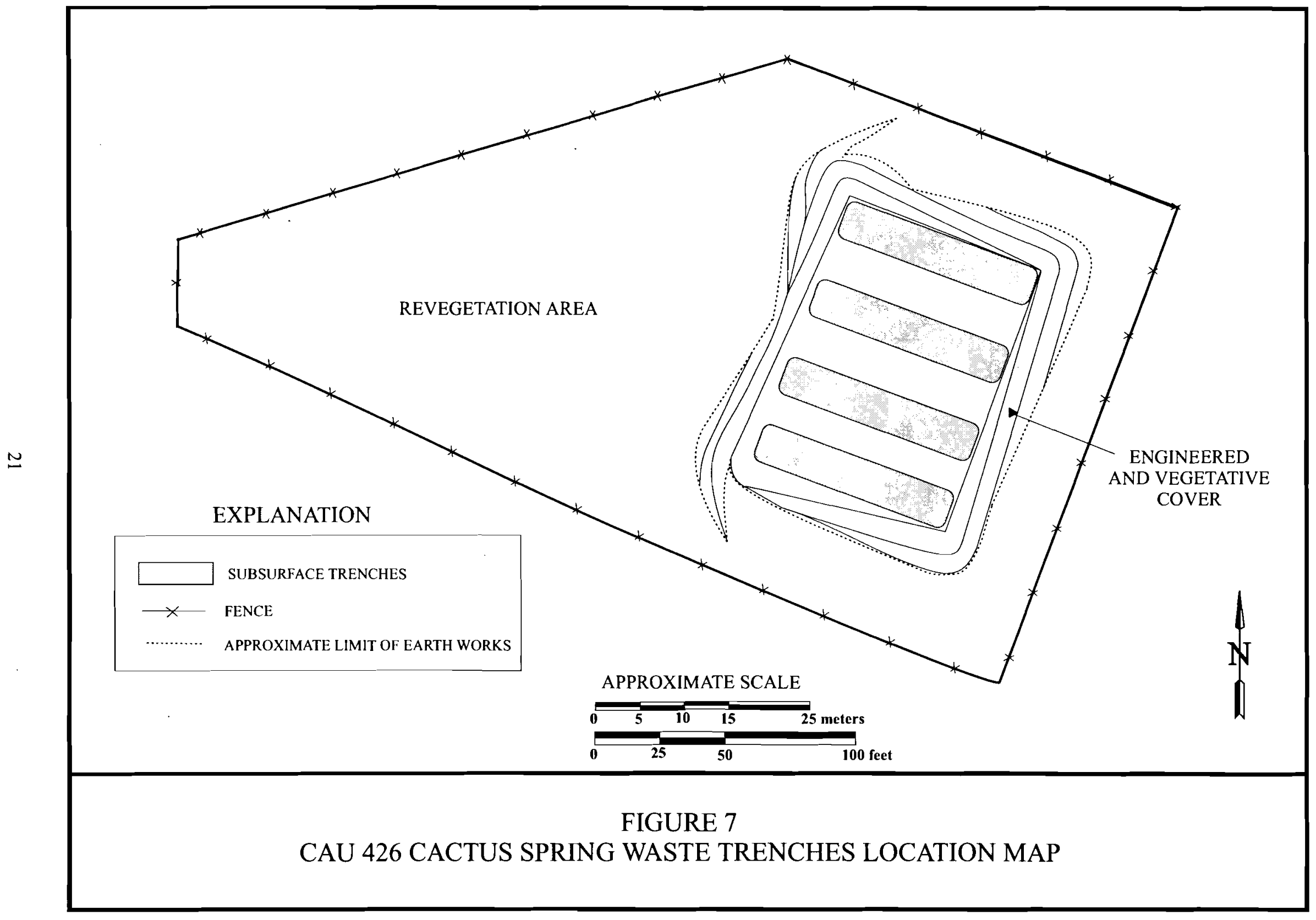


repaired. Repairs consisted of straightening several fence posts, replacing one fence post, and reattaching and tensioning fence wires and reattaching a warn sign to the fence post.

\subsubsection{CAU 426 Conclusions and Recommendations}

There was no evidence of erosion or significant surface-water flow on the site cover. Numerous small animal burrows present along and within the site fencing do not compromise the cover integrity. The cover was in good condition, with a good diversity of plant species growing on the cover and within the fenced area. A detailed plant census at CAU 426 was conducted in September of 2003, and the results are included in Attachment E. Overall, the cover area, fencing, signs, and gate were all in good condition. No further maintenance or repairs to the site are recommended at this time. It is also recommended that the frequency of site inspections remains the same, except in the event of severe weather, after which a nonscheduled site inspection may be required.

\subsection{CAU 427 Area 3 Septic Waste Systems 2, 6 (TTR)}

\subsubsection{CAU 427 Introduction}

Post-closure inspection requirements for CAU 427 (CAS 03-05-002-SW02, Septic Waste System; and CAS 03-05-006-SW06, Septic Waste System) are described in the CR for CAU 427: Area 3 Septic Waste Systems 2 and 6 (TTR) (DOE/NV, 1999b). The CR was submitted to the NDEP on August 16, 1999. The CR (containing the Post-Closure Inspection Plan) was approved by the NDEP on August 27, 1999.

As stated in Section 5.1 of the NDEP-approved CR (DOE/NV, 1999b), the annual Post-Closure inspection at CAU 427 consists of the following:

- Verification of the presence of all leachfield and septic tank below-grade markers.

- Verification that all warning signs are in place, intact, and readable.

- Visual observation of the soil and asphalt cover for indications of subsidence, erosion, and unauthorized use.

Site inspections were conducted on June 10, 2003, and December 3, 2003. A diagram showing the site location and configuration is shown in Figure 8. The site inspections were conducted in accordance with the Post-Closure Monitoring Plan (Attachment A) in the NDEP-approved CR (DOE/NV, 1999b). The Post-Closure Inspection Checklists are located in Attachment B. Copies of the field notes from each inspection are included as Attachment C. Attachment D consists of the photographic logs and photographs.

\subsubsection{CAU 427 Inspection Results}

\subsubsection{CAU 427 First Semiannual Inspection}

The first annual inspection was conducted on June 10, 2003. Eighteen of the 21 subsurface metal markers were located (Figure 8) at the corners of Leachfield A (two of four markers), Leachfield B (three of four markers), Pre-1965 Leachfield (four markers), Abandoned Leachfield (four markers), and Septic Tank 33-5 (five markers). The subsurface markers were easily detectible from the addition of contrasting red-colored rock placed in all of the leachfield 


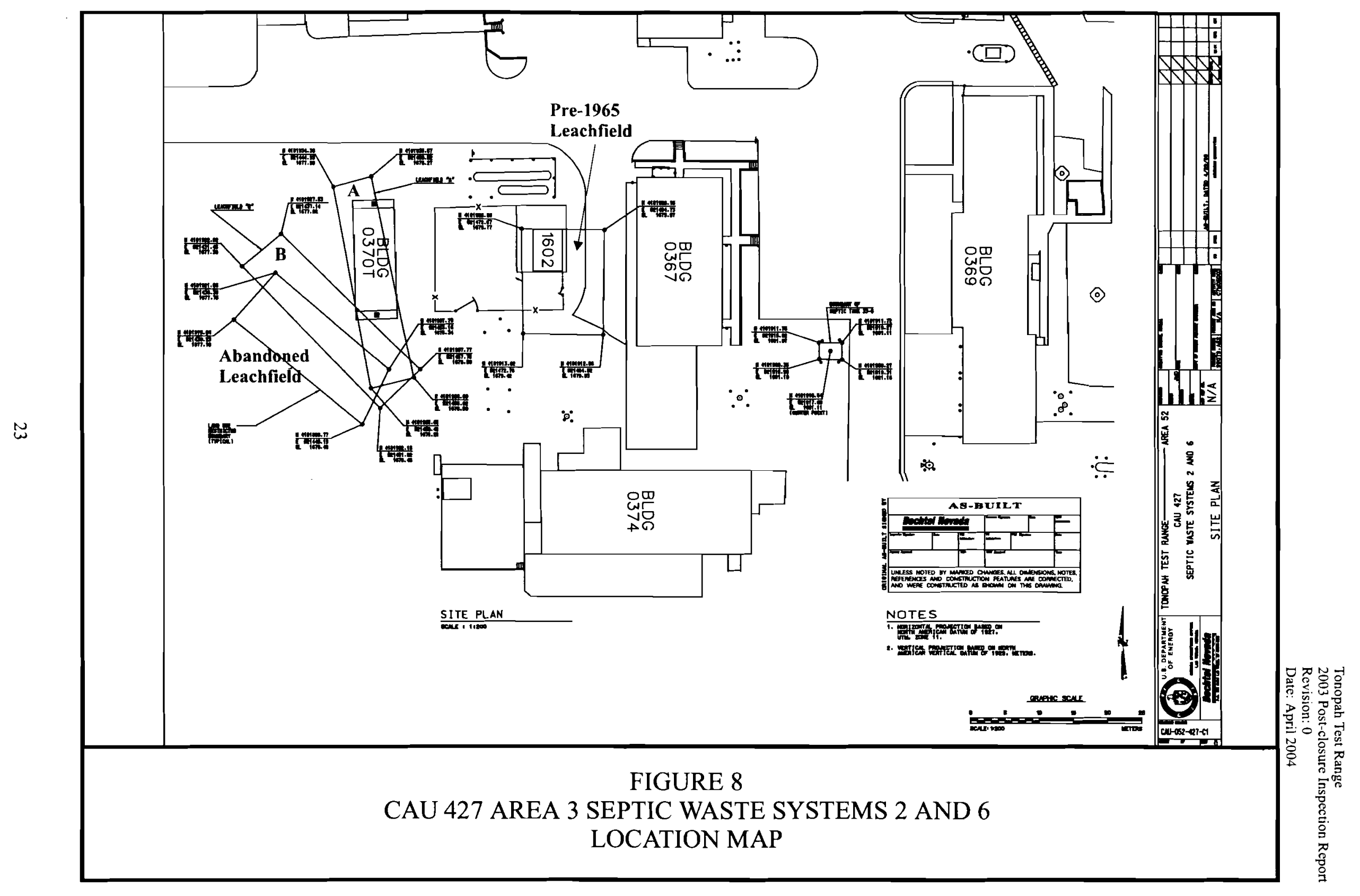


corners. The three subsurface markers and associated red rock could not be located at the north and west sides of Building 0370T due to excavation for underground utility maintenance in that area. At the time of inspection it could not be determined if the subsurface markers had been destroyed or damaged, or if the area had been covered during maintenance activities. A subsequent site visit on June 18,2003, was conducted to use geophysical methods to locate the buried metal plates marking the closed leachfield corners. All three subsurface metal markers were located and were found to be covered by several inches of fresh rock. The subsurface markers were not disturbed by the nearby excavation. An additional warning sign was requested for placement on the north side of Building 0370T to clarify the presence of buried waste in this area. The four existing warning signs were observed to be present at the as-built locations on Building 0370T (one sign on west side of building and one on south side of building), Building 0367 (one sign on west side of building), and east of Building 0367 (one sign on poles). The signs were legible and in good condition. The soil and asphalt cover areas are located in high traffic areas. Because of the traffic and yard maintenance activities, no vegetation was present in the areas. No evidence of subsidence, or erosion (e.g., cracks, depressions, erosional channeling) of the closed sites was observed. The site was in good condition.

\subsubsection{CAU 427 Second Semiannual Inspection}

The second annual inspection was conducted on December 10, 2003. All 21 subsurface metal markers were located (Figure 8) at the corners of Leachfield A (four markers), Leachfield B (four markers), Pre-1965 Leachfield (four markers), Abandoned Leachfield (four markers), and Septic Tank 33-5 (five markers). The five warning signs (including a newly installed sign on the north side of Building 0370T) were located. Photograph 39 in Attachment D shows the newly installed sign on Building 0370T. The signs were legible and in good condition. The soil and asphalt cover areas are located in high traffic areas. Because of the traffic and yard maintenance activities, no vegetation existed in the areas. No evidence of subsidence, erosion, or unauthorized use of the closed sites was observed. The site was in good condition.

\subsubsection{CAU 427 Maintenance and Repair}

Maintenance activities were completed at CAU 427 on July 09, 2003. Bechtel Nevada surveyors located all subsurface marker locations and added additional red rock to aid in locating the subsurface markers during future inspections (see Attachment D, photograph 40). Field notes for the repair activities are included in Attachment $C$. The three subsurface marker locations at Building 0370T that could not be located during the first 2003 inspection were uncovered to ensure the markers were in good condition. Once the markers were determined to be in good condition, the excavations were filled with red rock. Survey measurements were collected from structures adjacent to all of the buried markers to aid in the location of markers during future inspections. The measurement data is included within Attachment F. An additional userestriction warning sign was installed on the north side of Building 0370T to clarify the location of buried waste on this side of the building.

\subsubsection{CAU 427 Conclusions and Recommendations}

All five warning signs were in place and in good condition. Because of the traffic and yard maintenance activities, no vegetation existed in the areas. No surface features on the soil and asphalt cover indicating subsidence, erosion, or unauthorized use were observed. The site is 
currently in good condition and no additional maintenance activities are required at this time. The current inspection schedule should be maintained.

\subsection{CAU 453 Area 9 UXO Landfill (TTR)}

\subsubsection{CAU 453 Introduction}

Post-closure monitoring requirements for the CAU 453 (CAS 09-55-001-0952, Area 9 Landfill) are described in the CR for CAU 453: Area 9 UXO Landfill (TTR) (DOE/NV, 1999c). The CR was submitted to the NDEP on August 5, 1999. The CR (containing the Post-Closure Monitoring Plan) was approved by the NDEP on September 10, 1999.

As stated in Section 5.0 of the NDEP-approved CR (DOE/NV, 1999c), post-closure monitoring at CAU 453 consists of the following:

- Visual site inspections conducted twice a year to evaluate the condition of the cover.

- $\quad$ Additional, nonscheduled inspections, may be required after severe weather events.

- Verification that the site is secure and that the fence and posted warning signs are in good condition.

- $\quad$ Notice of any subsidence, erosion, unauthorized excavation, and other deficiencies that may compromise the integrity of the unit.

- $\quad$ Remedy of any deficiencies within 90 days of discovery.

- $\quad$ Preparation and submittal of an annual report.

Site inspections were conducted on June 10, 2003, and December 3, 2003. A diagram showing the site location and configuration is shown in Figure 9. The site inspections were conducted in accordance with the Post-Closure Monitoring Plan (Attachment A) in the NDEP-approved CR (DOE/NV, 1999c). The Post-Closure Inspection Checklists are located in Attachment B. Copies of the field notes from each inspection are included as Attachment C. Attachment D consists of the photographic logs and photographs.

\subsubsection{CAU 453 Inspection Results}

\subsubsection{CAU 453 First Semiannual Inspection}

The first inspection was completed on June 10,2003. The perimeter fence, signs, and concrete monuments marking the landfill cells were in good condition. Animal burrows were observed on the cover. The animal burrows and minor erosion rills on the cover do no compromise the integrity of the waste cell covers. Vegetation inside the fenced area, both on and off the landfill cover area, was sparse but healthy.

\subsubsection{CAU 453 Second Semiannual Inspection}

The second inspection was completed on December 3, 2003. The perimeter fence, concrete monuments, and site postings were in good condition. Minor small animal burrows were observed along the fence. At the time of inspection, a Jack Rabbit was observed inside the fenced area. The burrows had not compromised the integrity of the waste cell covers. No cracks, erosion, or settling features were observed in the other landfill cover areas. Vegetation 


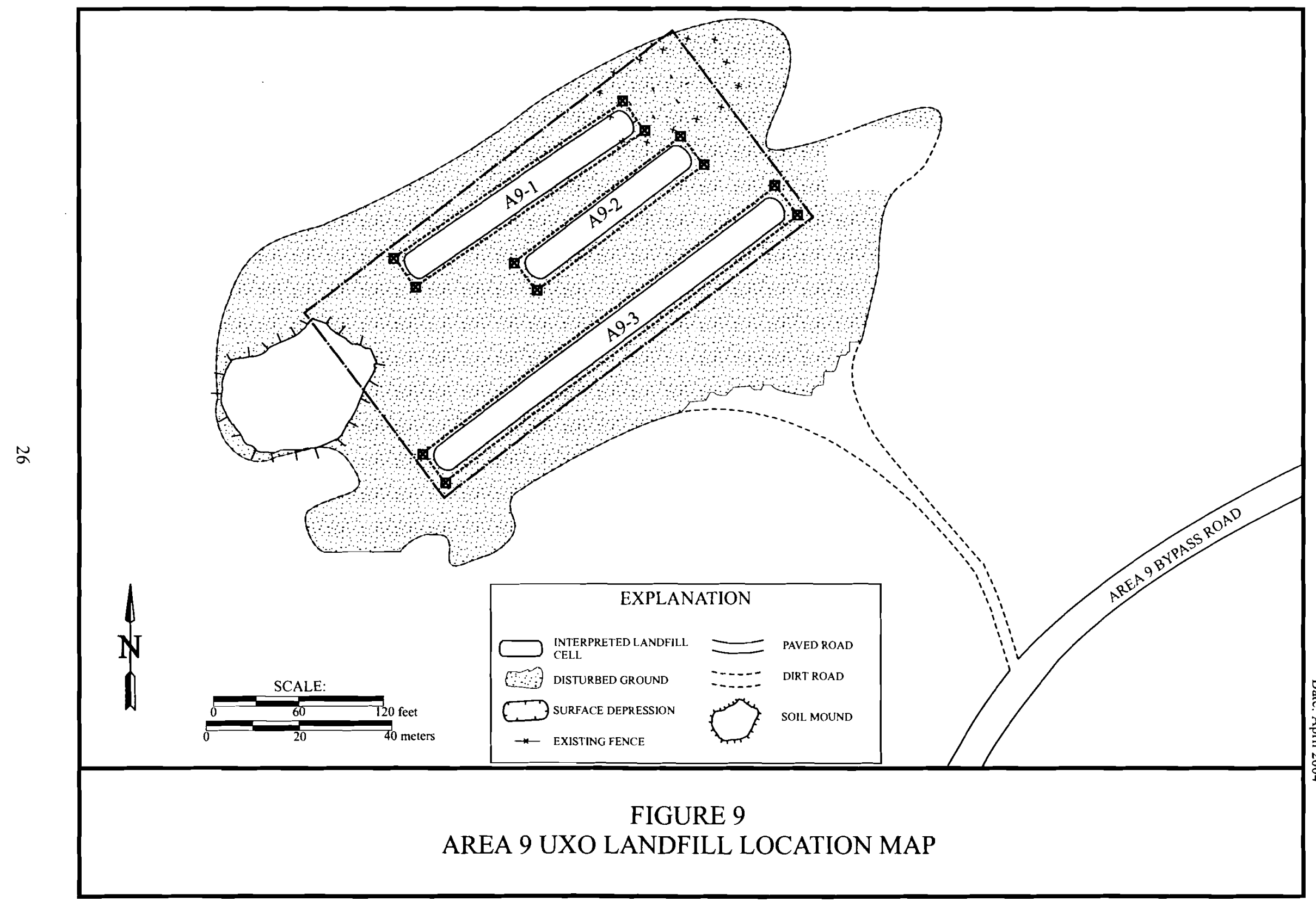

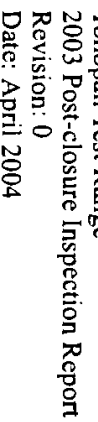


within the fenced area remains sparse and healthy. The cover over the landfill cells was in good condition.

\subsubsection{CAU 453 Maintenance and Repairs}

No maintenance or repairs to the site were made during the two site inspections.

\subsubsection{CAU 453 Conclusions and Recommendations}

The perimeter fence, monuments, and site postings were in good condition. No cracks, erosional features, or settling were observed in the landfill cover area. Plant growth on the landfill cover was sparse and was limited to native grasses and shrubs. Some animal burrows were observed along the fence and on the cover. The burrows and erosional rills had not compromised the integrity of the cover. The cover on the landfill cells was in good condition. No additional modifications or repairs to the cover are recommended at this time. It is also recommended that the frequency of site inspections remains the same, except in the event of severe weather, after which a nonscheduled site inspection may be required.

\subsection{CAU 487 Thunderwell Site (TTR)}

\subsubsection{CAU 487 Introduction}

CAU 487 consists of one CAS (RG-26-001-RGRV Thunderwell Site) and was closed in 2001 with a CADD/CR (DOE/NV, 200lb). The CADD/CR was submitted to the NDEP on November 21, 2001, and was subsequently approved by NDEP on December 17, 2001.

Buried waste and debris were present at the site but no contamination was found. Land-use restrictions were implemented at the site as presented within the CADD/CR, but no post-closure inspections were proposed (DOE/NV, 2001. Two separate land-use restrictions were implemented to address areas associated with subsurface geophysical anomalies (anomalies A-8 and A-17). One metal warning sign constructed of light-weight material was posted at each location to indicate the location of buried waste.

\subsubsection{CAU 487 Inspection Results}

The site was visited on December 3,2003, to verify that signs had been installed in the correct locations. The sign marking the location of anomaly A-8 was damaged and had been torn from the ground by horses (see Attachment D photograph 44). Anomaly A-8 includes buried waste that extends under an existing road and underground utilities. The sign marking the location of anomaly A-17 had been torn from the post and the post was bent to the ground by horses (see Attachment D photograph 43). During a subsequent visit to the site it was noted that the sign post had been completely torn from the ground. Horses tend to use rigid objects such as userestriction signs as scratching posts and subsequently damage the warning signs. During discussion of this site with NNSA/NSO, it was determined that above-grade concrete monuments and warning signs similar to those used to mark subsurface waste at CAU 424 would be more appropriate for this location. 


\subsubsection{CAU 487 Maintenance and Repairs}

No maintenance or repairs have been completed at the Thunderwell site at this time.

NNSA/NSO requested a revision to the $\mathrm{CADD} / \mathrm{CR}$ to include above-grade concrete monuments and signs, and require post-closure inspections to document the condition of the monuments and signs. The record of technical change (ROTC) to the CADD/CR is currently being prepared.

\subsubsection{CAU 487 Conclusions and Recommendations}

No post-closure inspections are required for CAU 487 and the existing postings are inadequate for the site. The requirement for concrete monuments with warning signs and post-closure inspections will be included in an ROTC to the CADD/CR. Upon approval of the CADD/CR ROTC, it is recommend that CAU 487 be officially added to the TTR Post-Closure Report. 


\subsection{SUMMARY}

\subsection{CAU 400 Bomblet Pit and Five Points Landfill}

The following conditions were reported for both sites during the post-closure monitoring inspections:

- $\quad$ Small animal burrows were present along the fence line of both sites.

- Condition of the covers was good, with healthy and very well-established plant species.

- Numerous bomblets and bomblet fragments were noted inside and outside the fenced area at the Bomblet Pit.

- Both sites were in good condition, with no evidence of subsidence or cracking on the cover.

- Minor erosion and sediment deposition was apparent at the Five Points Landfill, and sediment and debris had accumulated along the fencing on the east side of the site. This condition was also noted during the 2003 vegetative monitoring survey.

- Vegetation was in good condition but remained somewhat less dense than areas outside of the fence.

The following maintenance and repairs were conducted before and during the post-closure inspections:

- Backfilled several small animal burrows along the fence line.

- $\quad$ Removed several pieces of debris from outside and inside the fenced area at the Five Points Landfill.

The following recommendation has been proposed for both sites:

- Continue site inspections and vegetation monitoring until conditions warrant removal of the site fencing.

- The Five Points Landfill should be evaluated to determine if additional erosion and/or sediment/debris buildup has occurred. This evaluation will occur during the Spring 2004 site inspection.

- Fencing should remain at both sites until a future evaluation determines that the vegetation has matured to the same extent as the surrounding areas.

\subsection{CAU 404 Roller Coaster Lagoons and Trench}

The following conditions were reported for the site during the post-closure monitoring inspections:

- $\quad$ Fencing, posted warning signs, and gates were all in good condition.

- Several small animal burrows and evidence of animal activity were present along the fence line.

- $\quad$ No evidence of drainage or erosion was observed at the site.

- Cover condition was good, with a good diversity of plant species.

The following maintenance and repairs were conducted before and during the post-closure inspections:

- Backfilled small animal burrows along the fence line.

- $\quad$ No significant repairs or maintenance were completed during 2003. 
The following recommendations have been proposed for the site:

- $\quad$ No further maintenance or repairs to the site are recommended at this time.

- The frequency of site inspections should remain the same, except in the event of severe weather when inspections may be more frequent.

\subsection{CAU 407 Roller Coaster RadSafe Area}

The following conditions were reported for the site during the post-closure monitoring inspections:

- Cover remains in good condition, however numerous erosional rills are present on the cover side slopes.

- $\quad$ Fencing and signage appeared in good condition.

- $\quad$ No signs of subsidence were present on the cover.

- $\quad$ No vegetation was present on the cover due to recent maintenance activities.

The following maintenance and repairs were conducted before and during the post-closure inspections:

- $\quad$ Repaired fence, replaced several radiological postings, and added clean fill to repair minor erosion. Work was completed on July 16, 2003. Additional areas of erosion developed subsequent to these repair activities.

The following recommendations have been proposed for this site:

- Mulch and seed the cover and side slopes to help establish vegetation to minimize erosion due to surface-water runoff.

- The frequency of site inspections should remain the same, except in the event of severe weather when inspections may be more frequent.

\subsection{CAU 424 Area 3 Landfill Complexes}

The following conditions were reported for the site during the post-closure monitoring inspections:

- All monuments, attached signs, and survey pins were in good condition.

- No evidence of cracking or erosion of the covers was observed.

- Sparse yet healthy vegetation was present at all landfill complexes, except portions of Landfills A3-3 and A3-8 where high traffic inhibits vegetation growth.

- The condition of all eight Area 3 Landfill Complexes was found to be good.

Topographically low areas possibly caused by subsidence are present at areas of landfill cells A3-1 and A3-4.

The following maintenance and repairs were conducted before and during the post-closure inspections:

- Land-use coordinates were stamped on each above-grade and at-grade monument during maintenance activities completed on July 9, 2003.

- Elevation surveys were completed at landfill cells A3-1 and A3-4 covers.

The following recommendations have been proposed for the sites: 
- Clean fill should be added to the topographically low areas identified at landfill cells A3-1 and A3-4 to bring the areas to surrounding grade. Filling these low areas will prevent standing water and reduce the potential for percolation of water through the buried waste units.

- The frequency of site inspections should remain the same, except in the event of severe weather when inspections may be more frequent.

\subsection{CAU 426 Cactus Spring Waste Trenches}

The following conditions were reported for the site during the post-closure monitoring inspections:

- No evidence of erosion was observed on the cover.

- $\quad$ During the June 10, 2003 inspection, a portion of the south fence was noted as being damaged. Repairs were completed July 16, 2003.

- $\quad$ Fence and warning signs were in good condition during the inspection completed on December 3, 2003.

- $\quad$ Some animal burrows were present along the fence line.

- $\quad$ Russian Thistle (tumble weeds) were present inside the fenced area.

- Vegetation was healthy and well established, with a good diversity of native plant species.

The following maintenance and repairs were conducted before and during the post-closure inspections:

- $\quad$ Backfilled small burrows along the fence line.

- Two areas damaged by horses on the south portion of fence were repaired on July 16 , 2003.

The following recommendations have been proposed for this site:

- $\quad$ No further maintenance or repairs are recommended at this time.

- The frequency of site inspections should remain the same, except in the event of severe weather when inspections may be more frequent.

\subsection{CAU 427 Area 3 Septic Waste Systems 2, 6}

The following conditions were reported for the site during the post-closure monitoring inspections:

- Three subsurface leachfield markers could not be located during the inspection on June 10, 2003. The subsurface markers were subsequently located using geophysical methods and were found present under several inches of gravel.

- Subsurface markers and posted warning signs were in good condition during the inspection on December 3, 2003.

The following maintenance and repairs were conducted before and during the post-closure inspections:

- Maintenance activities were completed on July 9, 2003, to add additional red rock covering subsurface markers.

- Measurements between existing structures and locations of subsurface markers were made and documented to aid in future site inspections. 
- An additional warning sign was added to the north side of Building 0370T to clarify the location of buried waste in that area.

The following recommendations have been proposed for this site:

- No further maintenance or repairs are recommended at this time.

- $\quad$ The frequency of site inspections should remain the same, except in the event of severe weather when inspections may be more frequent.

\subsection{CAU 453 Area 9 UXO Landfill}

The following conditions were reported for the site during the post-closure monitoring inspections:

- Perimeter fence, monuments, site postings, and cover were in good condition.

- $\quad$ No subsidence, cracks, or erosion was observed.

- $\quad$ Growth on the landfill cover was sparse and limited to native grasses and shrubs.

- $\quad$ Animal burrows were observed along the fence.

The following maintenance and repairs were conducted before and during the post-closure Inspections:

- $\quad$ Filled small burrows along fence and on the cover.

- No significant maintenance or repairs to the site were made during the two site inspections or at other times during 2003.

The following recommendations have been proposed for this site:

- No additional modifications or repairs to the cover are recommended at this time.

- No further maintenance or repairs are recommended at this time.

- The frequency of site inspections should remain the same, except in the event of severe weather when inspections may be more frequent.

\subsection{CAU 487 Thunderwell Site}

Post-closure inspections are currently not required for CAU 487 but are included in this report for informational purposes. Land-use restrictions have been implemented at CAU 487 to address two areas of buried waste. The current version of the CADD/CR does not require post-closure inspections (DOE/NV, 2001. A ROTC to the CADD/CR is currently being prepared to require placement of concrete monuments and warning signs, and post-closure inspections. Upon approval of the CADD/CR ROTC, a request will be made to modify the TTR Post-Closure Inspection Report to include CAU 487. 
U.S. Department of Energy, Nevada Operations Office. 1997. Tonopah Test Range Closure Sites Revegetation Plan, Nevada, DOE/NV/11718-115 UC-702. Las Vegas, NV.

U.S. Department of Energy, Nevada Operations Office. 1998a. Closure Report for Corrective Action Unit 404: Roller Coaster Sewage Lagoons and North Disposal Trench, Tonopah Test Range, Nevada, DOE/NV/11718-187 UC-702, Las Vegas, NV.

U.S. Department of Energy, Nevada Operations Office. 1998b. Closure Report for Corrective Action Unit 426: Cactus Spring Waste Trenches, Tonopah Test Range, Nevada, DOE/NV/11718-226 UC-702, Las Vegas, NV.

U.S. Department of Energy, Nevada Operations Office. 1999a. Closure Report for Corrective Action Unit 424: Area 3 Landfill Complexes, Tonopah Test Range, Nevada, DOE/NV/11718--283, Las Vegas, NV.

U.S. Department of Energy, Nevada Operations Office. 1999b. Closure Report for Corrective Action Unit 427: Area 3 Septic Waste Systems 2 and 6, Tonopah Test Range, Nevada, DOE/NV--326, Las Vegas, NV.

U.S. Department of Energy, Nevada Operations Office. 1999c. Closure Report for Corrective Action Unit 453: Area 9 UXO Landfill, Tonopah Test Range, Nevada, DOE/NV/11718--284, Las Vegas, NV.

U.S. Department of Energy, Nevada Operations Office. 2001a. Closure Report for Corrective Action Unit 407: Roller Coaster RadSafe Area, Tonopah Test Range, Nevada, DOE/NV-694-REV1, Las Vegas, NV.

U.S. Department of Energy, Nevada Operations Office. 2001b. Corrective Action Decision Document/Closure Report for Corrective Action Unit 487: Thunderwell Site, Tonopah Test Range, Nevada, DOE/NV--761, Las Vegas, NV.

U.S. Department of Energy, Nevada Operations Office. 2002. Tonopah Test Range Post-Closure Inspection Annual Report, Tonopah Test Range, Nevada, Calendar Year 2002, DOE/NV-898-REV1, Las Vegas, NV. 
Date: April 2004

\section{THIS PAGE INTENTIONALLY LEFT BLANK}


Date: April 2004

\section{ATTACHMENT A}

\section{POST-CLOSURE INSPECTION PLANS}


Date: April 2004 


\section{CORRECTIVE ACTION UNIT (CAU) 404: ROLLER COASTER LAGOONS AND TRENCH POST-CLOSURE INSPECTION PLAN}

The following text appeared in the approved and published Closure Report (CR) for CAU 404: Roller Coaster Sewage Lagoons and North Disposal Trench, Tonopah Test Range, Nevada, Rev. 0, September 1998, DOE/NV/11718-187, UC-702. Las Vegas, Nevada

Post-Closure of the covers is intended to determine:

- If maintenance repairs to the perimeter fence are required.

- If remedial action is necessary to establish a vegetative cover.

- If maintenance and repairs to the engineered cover is required.

- When a cessation to post-closure monitoring can be proposed.

\section{POST-CLOSURE MONITORING}

The monitoring will consist of biannual (twice per year) visual inspections of:

- The cover for condition (subsidence, significant erosion, unauthorized excavation, etc.) and plant development.

- $\quad$ The fence and signs to determine if repairs are required.

Additional, nonscheduled inspections may be required after severe weather events such as heavy rainfall, flash flooding, and high winds. Any identified maintenance and repair requirements will be remediated within 90 days of discovery and documented in writing at the time of repair. Additional revegetation work would be conducted during the next revegetation window (October to February).

Intrusion into or sampling of the impacted materials in the East or West Sewage Lagoon is not proposed during the post-closure monitoring period.

Monitoring of the vegetative cover will be conducted during the first, third, and fifth year after revegetation. Monitoring during the first year will determine if germination of seeded plant species has occurred. By the third year, plant establishment will be evaluated. By the fifth year, the objective of determining if burrowing animals have moved onto the site and to what depth they might be expected to penetrate the cover. The erosion condition of the soil will be evaluated using a qualitative erosion condition classification developed by the Bureau of Land Management. Information gathered will be compared to natural conditions and will be used in assessing whether or not remedial action is necessary so that a viable vegetative cover is established. 


\section{ANNUAL REPORTING}

An annual report will be prepared that will provide the observations and describe modifications and/or repairs made to the cover and cover area. The annual report will be prepared following the second inspection of each year that post-closure monitoring is conducted. The annual reports will include the following information:

- Discussion of observations.

- Inspection checklist and maintenance record.

- Conclusions and recommendations.

A copy of each annual report will be submitted to the NDEP.

\section{DURATION}

The biannual inspections will be performed for five years after the planting of the vegetative covers, and will be documented on inspection forms.

Completion of post-closure monitoring of CAU 404 may be proposed after two consecutive years of visual inspections have not indicated the need to revegetate or provide maintenance to the vegetative covers. Completion of post-closure monitoring may be proposed within five years after the original revegetation of the site and include the removal of the fence since the plants will have attained a maturity to not be significantly affected by the grazing of wild horses. 


\section{CAU 407: ROLLER COASTER RADSAFE POST-CLOSURE MONITORING PLAN}

The following text appeared in the approved and published Closure Report (CR) for CAU 407: Roller Coaster RadSafe Area, Tonopah Test Range, Nevada, Rev. 1, December 2001, DOE/NV--694. Las Vegas, Nevada

Inspections consist of visually inspecting the cover for signs of erosion, animal burrows, cracks, water ponding, vegetation, and inspecting the fencing and postings. Inspections will be performed twice during the first six months after construction of the cover has been completed. After completion of the quarterly inspections, the cover systems will be inspected and monitored semiannually (twice per year) for the next two years. The frequency after the second year will be determined by NDEP, based on the results of the previous inspections. Any identified maintenance and repair requirements will be remedied within 90 working days of discovery and documented in writing at the time of repair. Results of all inspections in a given year will be addressed in a single annual report. The annual report will include the following information:

- Discussion of observations.

- Inspection checklist and maintenance record.

- Conclusions and recommendations.

A copy of each annual report will be submitted to the NDEP. A copy of the inspection checklist is provided in Appendix B. 
Date: April 2004

THIS PAGE INTENTIONALLY LEFT BLANK 


\section{CAU 424: AREA 3 LANDFILL COMPLEXES POST-CLOSURE MONITORING PLAN}

The following text appeared in the approved and published Closure Report (CR) for CAU 424: Area 3 Landfill Complexes, Tonopah Test Range, Nevada, Rev. 0, December 1998, DOE/NV/11718--283. Las Vegas, Nevada

Post-Closure of the covers is intended to determine:

- If maintenance repairs to the landfill soil covers are needed.

- If maintenance and repairs to the landfill markers and warning signs are needed.

- If modifications to the use restriction administrative controls are needed.

- If termination of post-closure inspection can be proposed in the future.

\section{POST-CLOSURE INSPECTION}

The inspection will consist of biannual (twice per year) visual inspections of:

- The soil cover for indications of subsidence, erosion, unauthorized use, etc.

- The landfill markers and warning signs to verify they are in-place, intact, and readable.

- The inspections will be documented on a checklist (Appendix B) and with photography, if needed.

Repairs to the soil covers (placement and compaction of additional backfill), landfill markers, and warning signs (repair, reposition, and/or replacement) may be required. Additional, nonscheduled inspections may be required after severe weather events such as heavy rainfall, flash flooding, and high winds. Any identified maintenance and repair requirements will be remedied within 90 days of discovery and documented in writing at the time of repair.

\section{ANNUAL REPORTING}

An annual report will be prepared that will provide the observations and describe modifications and/or repairs made to the cover and cover area. The annual report will be prepared following the second inspection of each year that post-closure monitoring is conducted. The annual reports will include the following information:

- Discussion of observations.

- Inspection checklist and maintenance record.

- Conclusions and recommendations.

A copy of each annual report will be submitted to the NDEP. 


\section{DURATION}

The biannual inspections will be performed for five years after the completion of closure activities, and will be documented on inspection forms.

Completion of post-closure monitoring of CAU 424 may be proposed after two consecutive years of visual inspections have not indicated recurrence of subsidence depressions. Completion of post-closure monitoring may be proposed by DOE/NV to the NDEP within five years after the completion of closure activities. 


\section{CAU 426: CACTUS SPRING WASTE TRENCHES POST-CLOSURE INSPECTION PLAN}

The following text appeared in the approved and published Closure Report (CR) for CAU 426: Cactus Spring Waste Trenches, Tonopah Test Range, Nevada, Rev. 0, August 1998, DOE/NV/11718-226-UC-702. Las Vegas, Nevada

Post-Closure of the covers is intended to determine:

- If maintenance repairs to the perimeter fence are required.

- If remedial action is necessary to establish a vegetative cover.

- If maintenance and repairs to the engineered cover is required.

- When a cessation to post-closure monitoring can be proposed.

\section{Post-Closure Monitoring}

The monitoring will consist of biannual (twice per year) visual inspections of:

- The cover for condition (subsidence, significant erosion, unauthorized excavation, etc.) and plant development.

- The fence and signs to determine if repairs are required.

Additional, nonscheduled inspections may be required after severe weather events such as heavy rainfall, flash flooding, and high winds. Any identified maintenance and repair requirements will be remediated within 90 days of discovery and documented in writing at the time of repair. Additional revegetation work would be conducted during the next revegetation window.

Intrusion into or sampling of the impacted materials in the East or West Sewage Lagoon is not proposed during the post-closure monitoring period.

Monitoring of the vegetative cover will be conducted during the first, third, and fifth year after revegetation. Monitoring during the first year will determine if germination of seeded plant species has occurred. By the third year, plant establishment will be evaluated. By the fifth year, the objective of determining if burrowing animals have moved onto the site and to what depth they might be expected to penetrate the cover. The erosion condition of the soil will be evaluated using a qualitative erosion condition classification developed by the Bureau of Land Management. Information gathered will be compared to natural conditions and will be used in assessing whether or not remedial action is necessary so that a viable vegetative cover is established. 


\section{ANNUAL REPORTING}

An annual report will be prepared that will provide the observations and describe modifications and/or repairs made to the cover and cover area. The annual report will be prepared following the second inspection of each year that post-closure monitoring is conducted. The annual reports will include the following information:

- Discussion of observations.

- Inspection checklist and maintenance record.

- Conclusions and recommendations.

A copy of each annual report will be submitted to the NDEP.

\section{DURATION}

The biannual inspections will be performed for five years after the planting of the vegetative covers, and will be documented on inspection forms.

Completion of post-closure monitoring of CAU 404 may be proposed after two consecutive years of visual inspections have not indicated the need to revegetate or provide maintenance to the vegetative covers. Completion of post-closure monitoring may be proposed within five years after the original revegetation of the site and include the removal of the fence since the plants will have attained a maturity to not be significantly affected by the grazing of wild horses. 


\section{CAU 427: AREA 3 SEPTIC WASTE SYSTEMS 2, 6 POST-CLOSURE MONITORING PLAN}

The following text appeared in the approved and published Closure Report (CR) for CAU 427: Area 3 Septic Waste Systems 2 and 6, Tonopah Test Range, Nevada, Rev. 0, July 1999, DOE/NV-- 326. Las Vegas, Nevada

Post-Closure of the covers is intended to determine:

- If maintenance and repairs to the closed leachfield or septic tank soil and asphalt covers are needed.

- If maintenance and repairs to the closed leachfield and septic tank markers and warning signs are needed.

- If modifications to the use restriction administrative controls are needed.

- If termination of post-closure inspection can be proposed in the future.

\section{POST-CLOSURE INSPECTION}

The inspection will consist of annual (once per year) visual inspections of:

- The soil and asphalt cover for indications of subsidence, erosion, unauthorized use, etc.

- The leachfield and septic tank markers and warning signs to verify they are in-place, intact, and readable.

- The inspections will be documented on a checklist (Appendix B) and, if needed, with photography.

Repairs to the soil covers (placement and compaction of additional backfill), landfill markers, and warning signs (repair, reposition, and/or replacement) may be required.

Inspections are not required after severe weather events such as heavy rainfall, flash flooding, and high winds, because the leachfield waste is buried in the subsurface. However, any identified maintenance and repair requirements will be remedied within 90 days of discovery and documented in writing at the time of repair.

\section{ANNUAL REPORTING}

An annual letter will provide the inspector's observations of CAU 427s land-use restricted areas and describe modifications and/or repairs made to Leachfield A, Leachfield B, pre-1965 Leachfield, 1965-1975 Leachfield, and/or Septic Tank 33-5. The annual post-closure inspection report will be prepared and submitted to NDEP before the completion of the fiscal year in which the inspection was conducted. The annual reports will include the following information:

- Discussion of observations. 
- Inspection checklist and maintenance record.

- Conclusions and recommendations.

A copy of each annual report will be submitted to the NDEP.

\section{DURATION}

The annual inspections will be performed for five years after the completion of closure activities, and will be documented on inspection forms.

Completion of post-closure monitoring of CAU 427 may be proposed by the DOE/NV to the NDEP if after two consecutive years of visual inspections, indications of subsidence/depression recurrences have not been detected. Completion of post-closure inspection may be proposed by $\mathrm{DOE} / \mathrm{NV}$ to the NDEP within five years after the completion of closure activities. 


\section{CAU 453: AREA 9 UXO LANDFILL MONITORING PLAN}

The following text appeared in the approved and published Closure Report (CR) for CAU 453: Area 9 UXO Landfill, Tonopah Test Range, Nevada, Rev. 0, July 1999, DOE/NV/11718 -- 284. Las Vegas, Nevada

Post-Closure of the covers is intended to determine:

- If maintenance and repairs to the cell soil covers are needed.

- If maintenance and repairs to the perimeter fence, warning signs, and monuments are needed.

- If modifications to the administrative use restrictions are needed.

- If termination of post-closure inspection can be proposed in the future.

\section{POST-CLOSURE INSPECTION}

The inspection will consist of biannual (once per year) visual inspections of:

- The cell soil cover for indications of subsidence, erosion, unauthorized use, etc.

- The perimeter fence, warning signs, and monuments for signs of wear disturbance, etc.

The inspections will be documented on a checklist and with photography, if needed. Repairs to the cell soil covers (placement and compaction of additional fill), perimeter fence, warning signs, and monuments (repair, reposition, and/or replacement) may be required. Additional, nonscheduled inspections may be required after severe weather events such as heavy rainfall, flash flooding, and high winds. Any identified maintenance and repair requirements will be remediated within 90 days of discovery and documented in writing at the time of repair.

\section{ANNUAL REPORTING}

An annual post-closure inspection report will be prepared that will provide the observations and describe modifications and/or repairs made to the cover and cover area. The annual report will be prepared and submitted to NDEP following the second inspection of each year that postclosure inspection is conducted. The annual reports will include the following information:

- Discussion of observations.

- Inspection checklist and maintenance record.

- Conclusions and recommendations. 


\section{DURATION}

The biannual inspections will be performed for five years after the completion of closure activities, and will be documented on inspection forms.

Completion of post-closure inspection of CAU 453 may be proposed by DOE/NV to NDEP within five years after the completion of closure activities. Completion of post-closure inspection may also be proposed by DOE/NV to NDEP if two consecutive years of visual inspections do not indicate the recurrence of subsidence depressions. 
Date: April 2004

\section{ATTACHMENT B}

\section{INSPECTION CHECKLISTS}




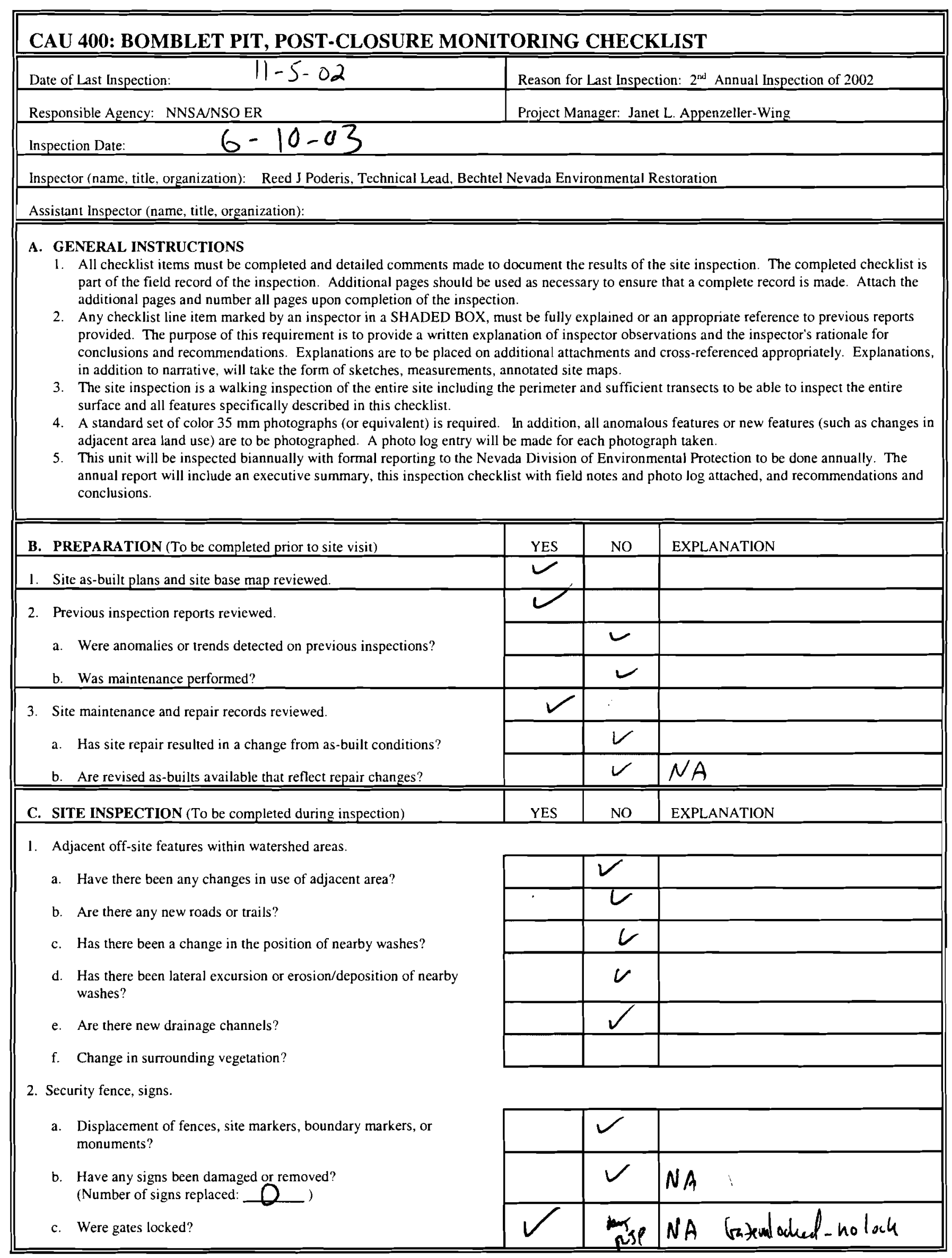




\section{CAU 400: BOMBLET PIT, POST-CLOSURE MONITORING CHECKLIST}

3. Waste Unit cover.

a. Is there evidence of settling?

b. Is there cracking?

c. Is there evidence of erosion around the cap (wind or water)?

d. Is there evidence of animal burrowing?

e. Have the site markers been disturbed by man or natural processes?

f. Do natural processes threaten to integrity of any cover or site marker?

g. Other?

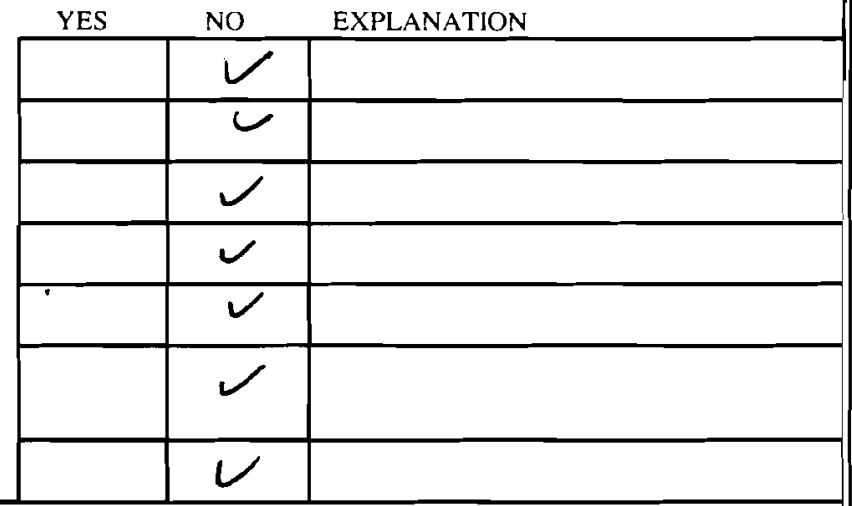

4. Vegetative cover

a. Is perimeter fence or mesh fencing damaged?

b. Is there evidence of horses or rabbits on site?

c. Is organic mulch and/or plants adequate to prevent erosion?

d. Are weedy annual plants present? If yes, are they a problem?

e. Are seeded plant species found on site?

f. Is there evidence of plant mortality?

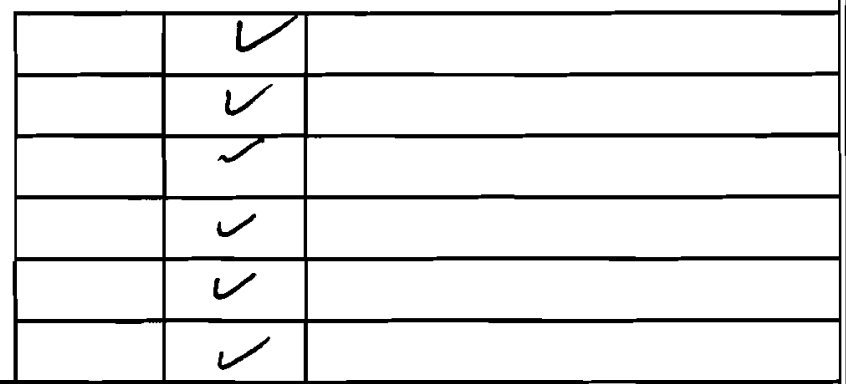

5. Photo Documentation

a. Has a photo $\log$ been prepared?

c. Number of photos exposed ( 3 )

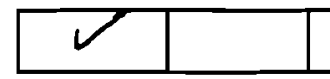

\section{FIELD CONCLUSIONS}

1. Is there an imminent hazard to the integrity of the unit? (Immediate report required)

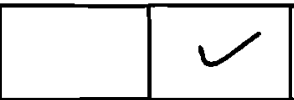

Person/Agency to whom report made

2. Are more frequent inspections required?

3. Are existing maintenance/repair actions satisfactory?

4. Is other maintenance/repair necessary?

5. Is current status/condition of vegetative cover satisfactory?

6. Rationale for field conclusions:

Sit in excollent condition

\section{E. CERTIFICATION}

I have conducted an inspection of the Bomblet Pit, CAU 400, at the TTR in accordance with the Post-Closure Monitoring Plan (see Closure Report) as recorded on this checklist, attached sheets, field notes, photo logs, and photographs.

Chief Inspector's Signature:

12

Title: Technical Lead Printed Name: Reed J Poderis

$$
\text { Date: } \quad 6-10-03
$$


CAU 400: 5 POINTS LANDFILL, POST-CLOSURE MONITORING CHECKLIST

\begin{tabular}{||l|l|}
\hline \hline Date of Last Inspection: $\quad 11-\zeta-02$ & Reason for Last Inspection: 2 $2^{\text {nul }}$ Annual Inspection of 2002 \\
\hline Responsible Agency: NNSA/NSO ER & Project Manager: Janet L. Appenzeller-Wing \\
\hline Inspection Date: $\quad 6-10-03$ & \\
\hline Inspector (name, title, organization): Reed J Poderis, Technical Lead, Bechtel Nevada Environmental Restoration \\
\hline Assistant Inspector (name, title, organization):
\end{tabular}

\section{A. GENERAL INSTRUCTIONS}

1. All checklist items must be completed and detailed comments made to document the results of the site inspection. The completed checklist is part of the field record of the inspection. Additional pages should be used as necessary to ensure that a complete record is made. Attach the additional pages and number all pages upon completion of the inspection.

2. Any checklist line item marked by an inspector in a SHADED BOX, must be fully explained or an appropriate reference to previous reports provided. The purpose of this requirement is to provide a written explanation of inspector observations and the inspector's rationale for conclusions and recommendations. Explanations are to be placed on additional attachments and cross-referenced appropriately. Explanations, in addition to narrative, will take the form of sketches, measurements, annotated site maps.

3. The site inspection is a walking inspection of the entire site including the perimeter and sufficient transects to be able to inspect the entire surface and all features specifically described in this checklist.

4. A standard set of color $35 \mathrm{~mm}$ photographs (or equivalent) is required. In addition, all anomalous features or new features (such as changes in adjacent area land use) are to be photographed. A photo log entry will be made for each photograph taken.

5. This unit will be inspected biannually with formal reporting to the Nevada Division of Environmental Protection to be done annually. The annual report will include an executive summary, this inspection checklist with field notes and photo log attached, and recommendations and conclusions.

\section{B. PREPARATION (To be completed prior to site visit)}

1. Site as-built plans and site base map reviewed.

2. Previous inspection reports reviewed.

a. Were anomalies or trends detected on previous inspections?

b. Was maintenance performed?

3. Site maintenance and repair records reviewed.

a. Has site repair resulted in a change from as-built conditions?

b. Are revised as-builts available that reflect repair changes?

C. SITE INSPECTION (To be completed during inspection)

\begin{tabular}{|c|c|c|l}
\cline { 3 - 4 } & & & \\
& YES & NO & EXPLANATION \\
\hline
\end{tabular}

1. Adjacent off-site features within watershed areas.

a. Have there been any changes in use of adjacent area?

b. Are there any new roads or trails?

c. Has there been a change in the position of nearby washes?

d. Has there been lateral excursion or erosion/deposition of nearby washes?

e. Are there new drainage channels?

f. Change in surrounding vegetation?

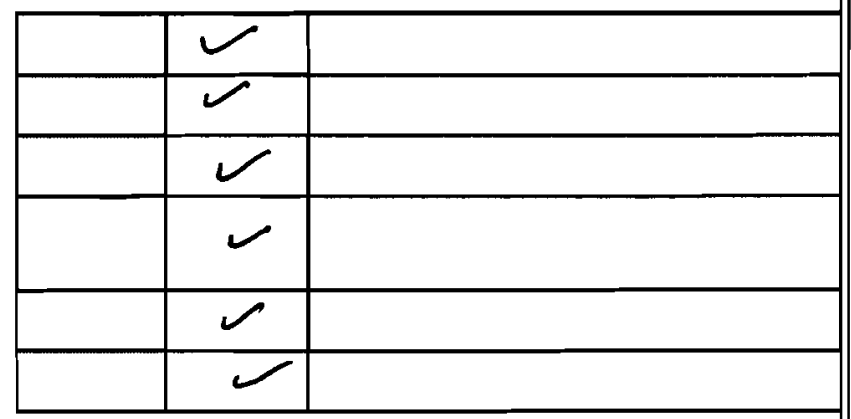

2. Security fence, signs.

a. Displacement of fences, site markers, boundary markers, or monuments?

b. Have any signs been damaged or removed? (Number of signs replaced:

O)

c. Were gates locked?

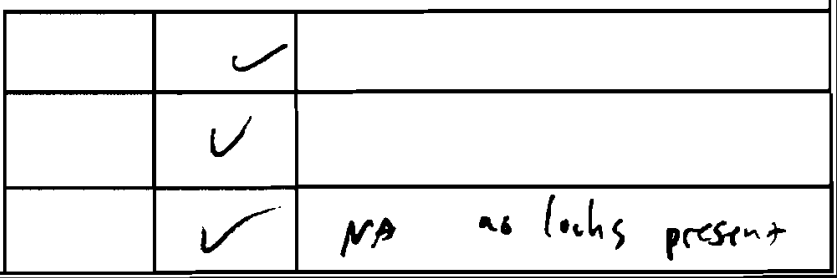




\section{CAU 400: 5 POINTS LANDFILL, POST-CLOSURE MONITORING CHECKLIST}

3. Waste Unit cover.
a. Is there evidence of settling?
b. Is there cracking?
c. Is there evidence of erosion around the cap (wind or water)?
d. Is there evidence of animal burrowing?
e. Have the site markers been disturbed by man or natural processes?
f. Do natural processes threaten to integrity of any cover or site marker?
g. Other?

\begin{tabular}{|l|l|l|}
\hline YES & NO & EXPLANATION \\
\hline & $\sim$ & \\
\hline & $\sim$ & \\
\hline & U & \\
\hline & $\sim$ & \\
\hline & $\sim$ & \\
\hline & $\sim$ & \\
\hline & $\checkmark$ & \\
\hline
\end{tabular}

4. Vegetative cover
a. Is perimeter fence or mesh fencing damaged?
b. Is there evidence of horses or rabbits on site?
c. Is organic mulch and/or plants adequate to prevent erosion?
d. Are weedy annual plants present? If yes, are they a problem?
e. Are seeded plant species found on site?
f. Is there evidence of plant mortality?

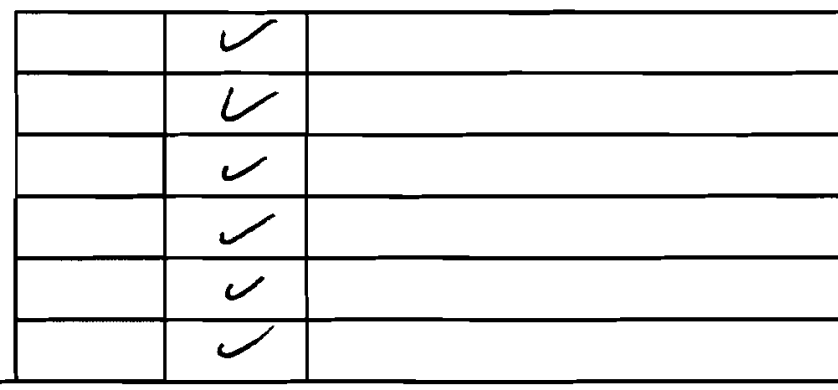

5. Photo Documentation

a. Has a photo $\log$ been prepared?

c. Number of photos exposed ( 4 )

\section{FIELD CONCLUSIONS}

1. Is there an imminent hazard to the integrity of the unit? (Immediate report required)

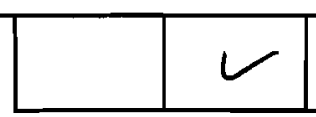

Person/Agency to whom report made:

2. Are more frequent inspections required?

3. Are existing maintenance/repair actions satisfactory?

4. Is other maintenance/repair necessary?

5. Is current status/condition of vegetative cover satisfactory?

6. Rationale for field conclusions: Cove in excellum conditom.

$$
\text { fence }+ \text { sate in expland condition. }
$$

\section{E. CERTIFICATION}

I have conducted an inspection of the 5 Points Landfill, CAU 400, at the TTR in accordance with the Post-Closure Monitoring Plan (see Closure Report) as recorded on this checklist, attacked sheets, field notes, photo logs, and photographs.

\begin{tabular}{||l|l}
\hline Chief Inspector's Signature: & Printed Name: Reed J Poderis \\
\hline Title: Technical Lead & Date: $6-10-03$
\end{tabular}




\section{CAU 404: ROLLER COASTER LAGOONS \& N. DISPOSAL TRENCH, POST-CLOSURE MONITORING CHECKLIST}

\begin{tabular}{||l|l|}
\hline \hline Date of Last Inspection: $\quad \mathrm{N}-5.02$ & Reason for Last Inspection: $2^{\mathrm{nd}}$ Annual Inspection of 2002 \\
\hline Responsible Agency: NNSA/NSO ER & Project Manager: Janet L. Appenzeller-Wing \\
\hline Inspection Date: $\quad 6-10-03$ & \\
\hline Inspector (name, title, organization): Reed J Poderis, Technical Lead, Bechtel Nevada Environmental Restoration \\
\hline Assistant Inspector (name, title, organization): \\
\hline \hline
\end{tabular}

\section{A. GENERAL INSTRUCTIONS}

1. All checklist items must be completed and detailed comments made to document the results of the site inspection. The completed checklist is part of the field record of the inspection. Additional pages should be used as necessary to ensure that a complete record is made. Attach the additional pages and number all pages upon completion of the inspection.

2. Any checklist line item marked by an inspector in a SHADED BOX, must be fully explained or an appropriate reference to previous reports provided. The purpose of this requirement is to provide a written explanation of inspector observations and the inspector's rationale for conclusions and recommendations. Explanations are to be placed on additional attachments and cross-referenced appropriately. Explanations, in addition to narrative, will take the form of sketches, measurements, annotated site maps.

3. The site inspection is a walking inspection of the entire site including the perimeter and sufficient transects to be able to inspect the entire surface and all features specifically described in this checklist.

4. A standard set of color $35 \mathrm{~mm}$ photographs is required. In addition, all anomalous features or new features (such as changes in adjacent area land use) are to be photographed. A photo log entry will be made for each photograph taken.

5. This unit will be inspected biannually with formal reporting to the Nevada Division of Environmental Protection to be done annually. The annual report will include an executive summary, this inspection checklist with field notes and photo log attached, and recommendations and conclusions.

\begin{tabular}{|c|c|c|c|}
\hline B. PREPARATION (To be completed prior to site visit) & YES & NO & EXPLANATION \\
\hline 1. Site as-built plans and site base map reviewed. & $\mathcal{L}$ & & \\
\hline Previous inspection reports reviewed. & U & & \\
\hline a. Were anomalies or trends detected on previous inspections? & & $\sim$ & \\
\hline b. Was maintenance performed? & & $w$ & \\
\hline \multirow{3}{*}{$\begin{array}{l}\text { Site maintenance and repair records reviewed. } \\
\text { a. Has site repair resulted in a change from as-built conditions? }\end{array}$} & & $\sim$ & $N A$ \\
\hline & & 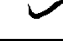 & \\
\hline & & V & NA \\
\hline C. SITE INSPECTION (To be completed during inspection) & YES & NO & EXPLANATION \\
\hline \multicolumn{4}{|l|}{ 1. Adjacent off-site features within watershed areas. } \\
\hline a. Have there been any changes in use of adjacent area? & & $\checkmark$ & \\
\hline b. Are there any new roads or trails? & & $\checkmark$ & \\
\hline c. Has there been a change in the position of nearby washes? & & 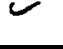 & \\
\hline d. Has there been lateral excursion or erosion/deposition of nearby & & $\checkmark$ & \\
\hline e. Are there new drainage channels? & & $\checkmark$ & \\
\hline f. Change in surrounding vegetation? & & & \\
\hline \multicolumn{4}{|l|}{ 2. Security fence, signs. } \\
\hline $\begin{array}{l}\text { a. Displacement of fences, site markers, boundary markers, or } \\
\text { monuments? }\end{array}$ & & $\checkmark$ & \\
\hline b. Have any signs been damaged or famoved? & & U & \\
\hline c. Were gates locked? & & 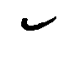 & NA no locks presentr \\
\hline
\end{tabular}




\section{CAU 404: ROLLER COASTER LAGOONS \& N. DISPOSAL TRENCH, POST-CLOSURE MONITORING CHECKLIST}

3. Waste Unit cover.

a. Is there evidence of settling?

b. Is there cracking?

c. Is there evidence of erosion around the cap (wind or water)?

d. Is there evidence of animal burrowing?

e. Have the site markers been disturbed by man or natural processes?

f. Do natural processes threaten to integrity of any cover or site marker?

g. Other?

\begin{tabular}{|c|c|c|}
\hline YES & $\mathrm{NO}$ & EXPLANATION \\
\hline & $\sim$ & \\
\hline & $V$ & 2 spall buspowe under trace \\
\hline $\mathscr{L}$ & & \\
\hline & & \\
\hline & $\mathcal{V}$ & \\
\hline & $\checkmark$ & \\
\hline
\end{tabular}

4. Vegetative cover

a. Is perimeter fence or mesh fencing damaged?

b. Is there evidence of horses or rabbits on site?

c. Is organic mulch adequate to prevent erosion?

d. Are weedy annual plants present? If yes, are they a problem?

e. Are seeded plant species found on site?

f. Is there evidence of plant mortality?

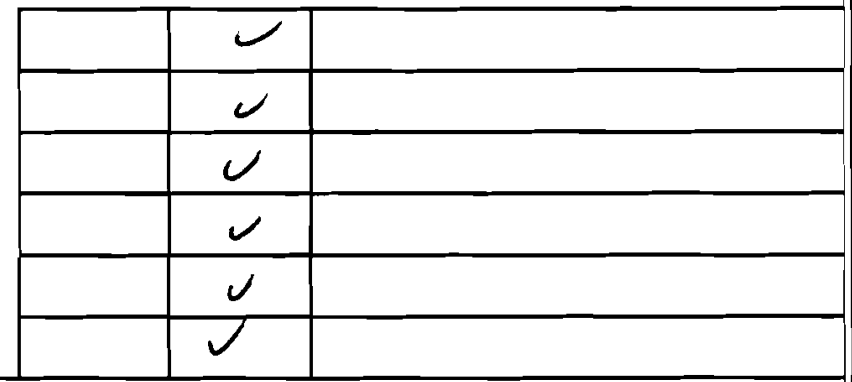

5. Photo Documentation

a. Has a photo log been prepared?

c. Number of photos exposed $(4$ )

\section{FIELD CONCLUSIONS}

1. Is there an imminent hazard to the integrity of the unit? (Immediate report required)

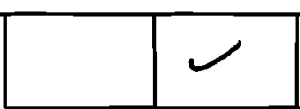

Person/Agency to whom report made

2. Are more frequent inspections required?

3. Are existing maintenance/repair actions satisfactory?

4. Is other maintenance/repair necessary?

5. Is current status/condition of vegetative cover satisfactory?

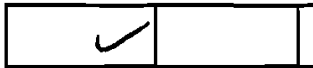

6. Rationale for field conclusions:

$$
\begin{aligned}
& \text { Cove in suod condater, signs secure, gate in exclkat } \\
& \text { condition. }
\end{aligned}
$$

\section{E. CERTIFICATION}

I have conducted an inspection of the Roller Coaster Sewage Lagoons \& North Disposal Trench, CAU 404, at the TTR in accordance with the PostClosure Monitoring Plan (see Closure Report) as recorded on this checklist, attached sheets. field notes, photo logs, and photographs.

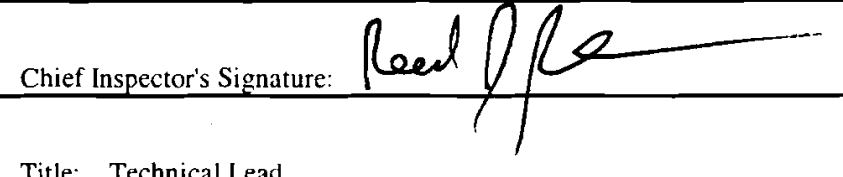

Reed J Poderis

Printed Name:

Title: Technical Lead

Date: $6-10-03$ 
CAU 407: ROLLER COASTER RADSAFE AREA, POST-CLOSURE MONITORING CHECKLIST

\begin{tabular}{|l|l||}
\hline \hline Date of Last Inspection: $11-5-02$ & Reason for Last Inspection: $2^{\text {nd }}$ Annual Inspection of 2002 \\
\hline Responsible Agency: NNSA/NSO ER & Project Manager: Janet L. Appenzeller-Wing \\
\hline Inspection Date: $\quad 6-10-09$ & \\
\hline Inspector (name, title, organization): Reed J Poderis, Technical Lead, Bechtel Nevada Environmental Restoration \\
\hline Assistant Inspector (name, title. organization):
\end{tabular}

\section{A. GENERAL INSTRUCTIONS}

1. All checklist items must be completed and detailed comments made to document the results of the site inspection. The completed checklist is part of the field record of the inspection. Additional pages should be used as necessary to ensure that a complete record is made. Attach the additional pages and number all pages upon completion of the inspection.

2. Any checklist line item marked by an inspector in a SHADED BOX, must be fully explained or an appropriate reference to previous reports provided. The purpose of this requirement is to provide a written explanation of inspector observations and the inspector's rationale for conclusions and recommendations. Explanations are to be placed on additional attachments and cross-referenced appropriately. Explanations, in addition to narrative. will take the form of sketches, measurements, annotated site maps.

3. The site inspection is a walking inspection of the entire site including the perimeter and sufficient transects to be able to inspect the entire surface and all features specifically described in this checklist.

4. A standard set of color $35 \mathrm{~mm}$ photographs is required. In addition, all anomalous features or new features (such as changes in adjacent area land use) are to be photographed. A photo log entry will be made for each photograph taken.

5. This unit will be inspected biannually with formal reporting to the Nevada Division of Environmental Protection to be done annually. The annual report will include an executive summary, this inspection checklist with field notes and photo log attached, and recommendations and conclusions.

\begin{tabular}{|c|c|c|c|}
\hline B. PREPARATION (To be completed prior to site visit) & YES & NO & EXPLANATION \\
\hline 1. Site as-built plans and site base map reviewed. & & & \\
\hline \multicolumn{4}{|l|}{ 2. Previous inspection reports reviewed. } \\
\hline \multicolumn{4}{|l|}{ a. Were anomalies or trends detected on previous inspections? } \\
\hline b. Was maintenance performed? & & & \\
\hline \multirow{3}{*}{$\begin{array}{l}\text { Site maintenance and repair records reviewed. } \\
\text { a. Has site repair resulted in a change from as-built conditions? } \\
\text { b. Are revised as-builts available that reflect repair changes? }\end{array}$} & & レ & $N_{A}$ \\
\hline & & & \\
\hline & & & $N A$ \\
\hline C. SITE INSPECTION (To be completed during inspection) & YES & NO & EXPLANATION \\
\hline \multicolumn{4}{|l|}{ 1. Adjacent off-site features within watershed areas. } \\
\hline \multicolumn{4}{|l|}{ a. Have there been any changes in use of adjacent area? } \\
\hline \multicolumn{4}{|l|}{ b. Are there any new roads or trails? } \\
\hline \multicolumn{4}{|l|}{ c. Has there been a change in the position of nearby washes? } \\
\hline \multicolumn{4}{|l|}{$\begin{array}{l}\text { d. Has there been lateral excursion or erosion/deposition of nearby } \\
\text { washes? }\end{array}$} \\
\hline \multicolumn{4}{|l|}{ e. Are there new drainage channels? } \\
\hline f. Change in surrounding vegetation? & & & \\
\hline \multicolumn{4}{|l|}{ 2. Security fence, signs. } \\
\hline \multicolumn{4}{|l|}{$\begin{array}{l}\text { a. Displacement of fences, site markers, boundary markers, or } \\
\text { monuments? }\end{array}$} \\
\hline \multirow{2}{*}{$\begin{array}{l}\text { b. Have any signs been damaged or temoved? } \\
\text { (Number of signs replaced: }\end{array}$} & & & Signs in sood conditio \\
\hline & & & no gat presert \\
\hline
\end{tabular}




\section{CAU 407: ROLLER COASTER RADSAFE AREA, POST-CLOSURE MONITORING CHECKLIST}

3. Waste Unit cover.

a. Is there evidence of settling?

b. Is there cracking?

c. Is there evidence of erosion around the cap (wind or water)?

d. Is there evidence of animal burrowing?

e. Do natural processes threaten to integrity of any cover or site marker?

f. Other?

\begin{tabular}{|c|c|c|}
\hline YES & NO & EXPLANATION \\
\hline & $v$ & \\
\hline & ש & \\
\hline$レ$ & & minol rills on $s+6$ slopes \\
\hline$\checkmark$ & & several spull berrows alongce \\
\hline & v & \\
\hline & & \\
\hline
\end{tabular}

4. Vegetative cover.

a. Is perimeter fence or mesh fencing damaged?

b. Is there evidence of horses or rabbits on site?

c. Is organic mulch adequate to prevent erosion?

d. Are weedy annual plants present? If yes, are they a problem?

e. Are seeded plant species found on site?

f. Is there evidence of plant mortality?

\begin{tabular}{|l|l|l|}
\hline$v$ & & loose in s6 cophe \\
\hline$v$ & & hase scat presen \\
\hline & $\sim$ & \\
\hline & $\checkmark$ & \\
\hline & $\sim$ & \\
\hline & $\sim$ & \\
\hline
\end{tabular}

5. Photo Documentation

a. Has a photo log been prepared?

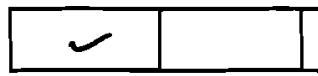

c. Number of photos exposed 13 )

\section{FIELD CONCLUSIONS}

1. Is there an imminent hazard to the integrity of the unit? (Immediate report required)

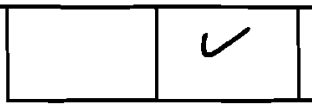

Person/Agency to whom report made

2. Are more frequent inspections required?

3. Are existing maintenance/repair actions satisfactory?

4. Is other maintenance/repair necessary?

5. Is current status/condition of vegetative cover satisfactory?

Secore loase fince cave

6. Rationale for field conclusions:

Cover in soul conditien, fence to be secoijal

\section{E. CERTIFICATION}

I have conducted an inspection of the Roller Coaster RadSafe Area, CAU 407, at the TTR in accordance with the Post-Closure Monitoring Plan (see Closure Report) as recorded on this checklist, attached sheets. field notes, photo logs. and photographs.

\begin{tabular}{|l|l|}
\hline \multicolumn{1}{|c|}{$($ Ceed $)(00$} & Printed Name: Reed J Poderis \\
\hline Title: Technical Lead & Date: $6-10-03$ \\
\hline
\end{tabular}




\section{CAU 424: AREA 3 LANDFILL COMPLEX, POST-CLOSURE INSPECTION CHECKLIST}

\begin{tabular}{|l|l|}
\hline \hline Date of Last Inspection: $11-5-02$ & Reason for Last Inspection: $2^{\text {nd }}$ Annual Inspection of 2002 \\
\hline Responsible Agency: NNSANSO ER & Project Manager: Janet L. Appenzeller-Wing \\
\hline Inspection Date: $\quad 6-10-03$ & \\
\hline Inspector (name, title, organization): Reed J Poderis, Technical Lead, Bechtel Nevada Environmental Restoration \\
\hline Assistant Inspector (name, title, organization): \\
\hline \hline
\end{tabular}

\section{A. GENERAL INSTRUCTIONS}

1. All checklist items must be completed and detailed comments made to document the results of the site inspection. The completed checklist is part of the field record of the inspection. Additional pages should be used as necessary to ensure that a complete record is made. Attach the additional pages and number all pages upon completion of the inspection.

2. Any checklist line item marked by an inspector in a SHADED BOX, must be fully explained or an appropriate reference to previous reports provided. The purpose of this requirement is to provide a written explanation of inspector observations and the inspector's rationale for conclusions and recommendations. Explanations are to be placed on additional attachments and cross-referenced appropriately. Explanations, in addition to narrative, will take the form of sketches, measurements, annotated site maps.

3. The site inspection is a walking inspection of the entire site including the perimeter and sufficient transects to be able to inspect the entire surface and all features specifically described in this checklist.

4. A standard set of color $35 \mathrm{~mm}$ photographs (or equivalent) is required. In addition, all anomalous features or new features (such as changes in adjacent area land use) are to be photographed. A photo log entry will be made for each photograph taken.

5. This unit will be inspected biannually with formal reporting to the Nevada Division of Environmental Protection to be done annually. The annual report will include an executive summary, this inspection checklist with field notes and photo log attached, and recommendations and conclusions.

\begin{tabular}{|c|c|c|c|}
\hline B. PREPARATION (To be completed prior to site visit) & YES & NO & EXPLANATION \\
\hline 1. Site as-built plans and site base map reviewed. & 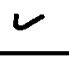 & & \\
\hline \multirow{3}{*}{$\begin{array}{l}\text { Previous inspection reports reviewed. } \\
\text { a. Were anomalies or trends detected on previous inspections? }\end{array}$} & $\sim$ & & \\
\hline & & & \\
\hline & & & \\
\hline \multicolumn{4}{|l|}{ 3. Site maintenance and repair records reviewed. } \\
\hline \multicolumn{4}{|l|}{ a. Has site repair resulted in a change from as-built conditions? } \\
\hline b. Are revised as-builts available that reflect repair changes? & & & $N A$ \\
\hline C. SITE INSPECTION (To be completed during inspection) & YES & NO & EXPLANATION \\
\hline
\end{tabular}

1. Adjacent off-site features within watershed areas.

a. Have there been any changes in use of adjacent area?

b. Are there any new roads or trails?

c. Has there been a change in the position of nearby washes?

d. Has there been lateral excursion or erosion/deposition of nearby washes?

e. Are there new drainage channels?

f. Change in surrounding vegetation?

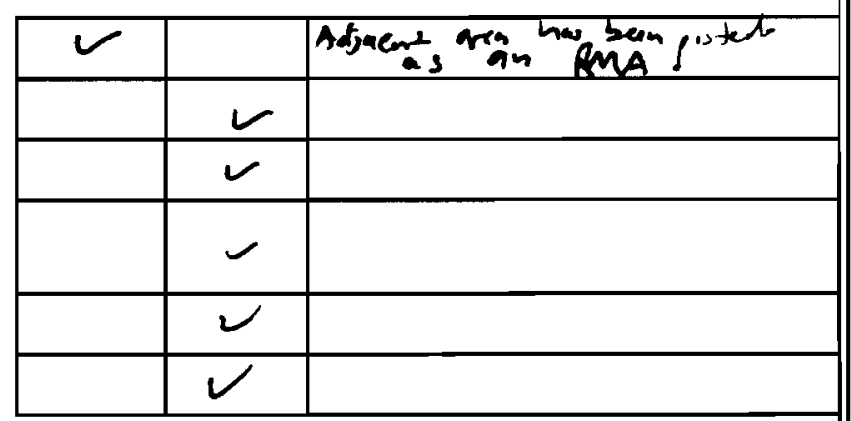

2. Security fence, signs.

a. Displacement of fences, site markers, boundary markers, or monuments?

b. Have any signs been damaged or removed? (Number of signs replaced:

c. Were gates locked?

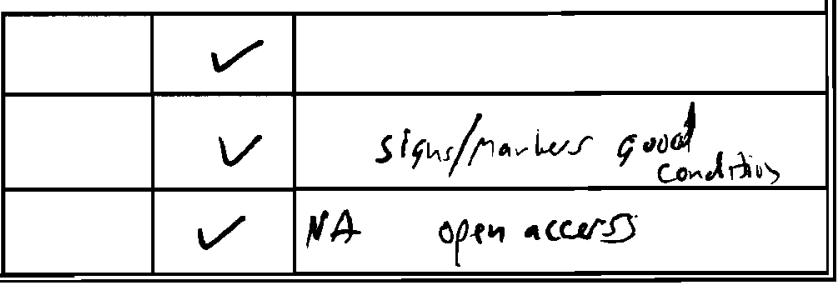




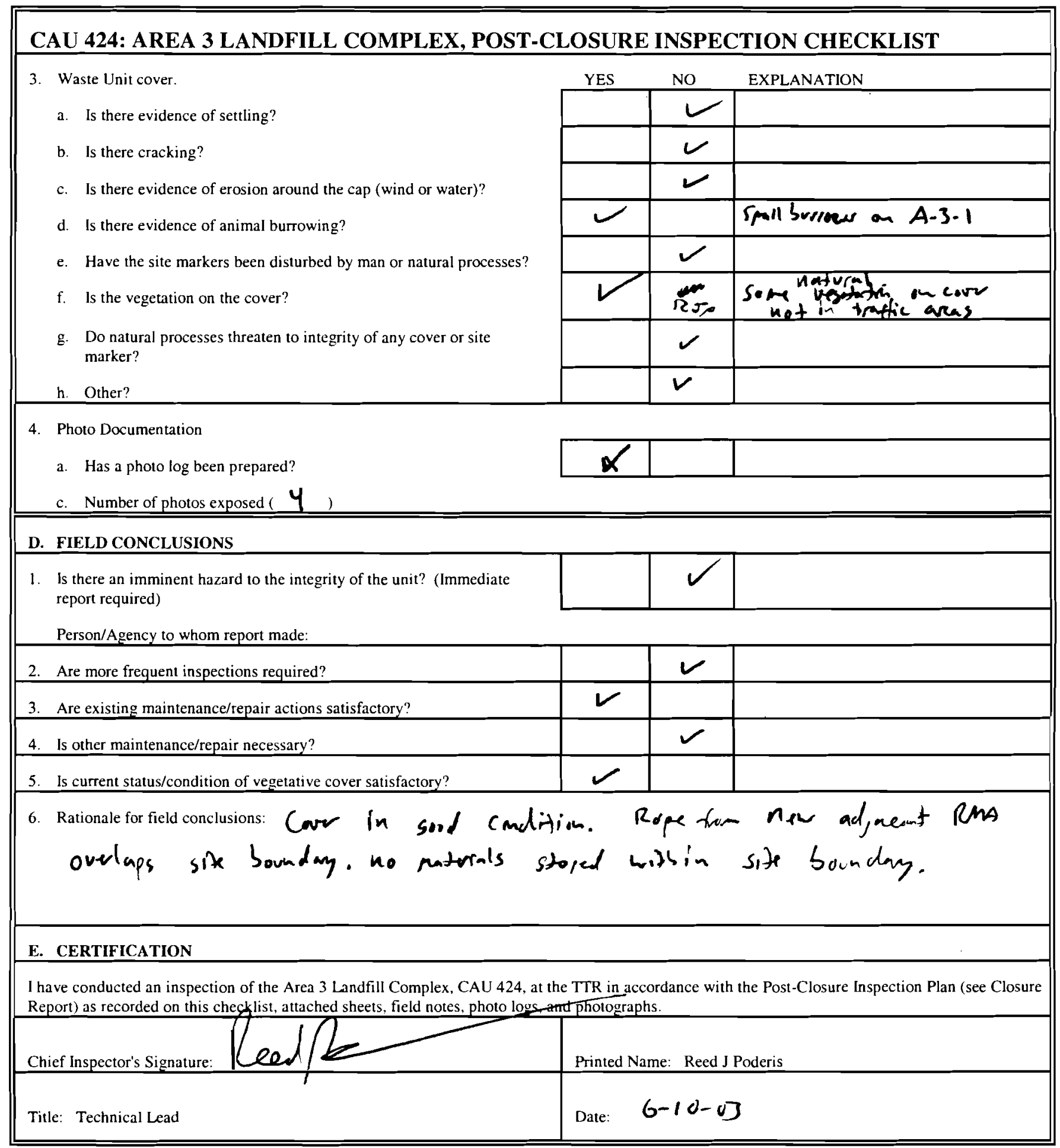




\begin{tabular}{|c|c|c|c|}
\hline \multicolumn{4}{|c|}{ CAU 426: CACTUS SPRING WASTE TRENCHES, POST-CLOSURE MONITORING CHECKLIST } \\
\hline Date of Last Inspection: $11-9-02$ & \multicolumn{3}{|c|}{ Reason for Last Inspection: $2^{\text {nd }}$ Annual Inspection of 2002} \\
\hline $\begin{array}{r}n^{P} \\
\text { Responsible Agency: NNSA/NSO ER }\end{array}$ & \multicolumn{3}{|c|}{ Project Manager: Janet L. Appenzeller-Wing } \\
\hline \multicolumn{4}{|l|}{ Inspection Date: $610-03$} \\
\hline \multicolumn{4}{|c|}{ Inspector (name, title, organization): Reed J Poderis, Technical Lead, Bechtel Nevada Environmental Restoration } \\
\hline \multicolumn{4}{|l|}{ Assistant Inspector (name, title, organization): } \\
\hline \multicolumn{4}{|c|}{$\begin{array}{l}\text { A. GENERAL INSTRUCTIONS } \\
\text { 1. All checklist items must be completed and detailed comments made to document the results of the site inspection. The completed checklist is } \\
\text { part of the field record of the inspection. Additional pages should be used as necessary to ensure that a complete record is made. Attach the } \\
\text { additional pages and number all pages upon completion of the inspection. } \\
\text { 3. Any checklist line item marked by an inspector in a SHADED BOX, must be fully explained or an appropriate reference to previous reports } \\
\text { provided. The purpose of this requirement is to provide a written explanation of inspector observations and the inspector's rationale for } \\
\text { conclusions and recommendations. Explanations are to be placed on additional attachments and cross-referenced appropriately. Explanations, } \\
\text { in addition to narrative, will take the form of sketches, measurements, annotated site maps. } \\
\text { 4. The site inspection is a walking inspection of the entire site including the perimeter and sufficient transects to be able to inspect the entire } \\
\text { surface and all features specifically described in this checklist. } \\
\text { 5. A standard set of color } 35 \mathrm{~mm} \text { photographs (or equivalent) is required. In addition, all anomalous features or new features (such as changes in } \\
\text { adjacent area land use) are to be photographed. A photo log entry will be made for each photograph taken. } \\
\text { 6. This unit will be inspected biannually with formal reporting to the Nevada Division of Environmental Protection to be done annually. The } \\
\text { annual report will include an executive summary, this inspection checklist with field notes and photo log attached, and recommendations and } \\
\text { conclusions. }\end{array}$} \\
\hline B. PREPARATION (To be completed prior to site visit) & YES & NO & EXPLANATION \\
\hline 1. Site as-built plans and site base map reviewed. & & & \\
\hline \multirow{3}{*}{$\begin{array}{l}\text { 2. Previous inspection reports reviewed. } \\
\text { a. Were anomalies or trends detected on previous inspections? } \\
\text { b. Was maintenance performed? }\end{array}$} & & & \\
\hline & & & \\
\hline & & & \\
\hline \multirow{3}{*}{$\begin{array}{l}\text { 3. Site maintenance and repair records reviewed. } \\
\text { a. Has site repair resulted in a change from as-built conditions? } \\
\text { b. Are revised as-builts available that reflect repair changes? }\end{array}$} & & & $N A$ \\
\hline & & & \\
\hline & & & $N A$ \\
\hline C. SITE INSPECTION (To be completed during inspection) & YES & No & EXPLANATION \\
\hline \multicolumn{4}{|l|}{ 1. Adjacent off-site features within watershed areas. } \\
\hline a. Have there been any changes in use of adjacent area? & & & \\
\hline b. Are there any new roads or trails? & & & \\
\hline c. Has there been a change in the position of nearby washes? & & & \\
\hline $\begin{array}{l}\text { d. Has there been lateral excursion or erosion/deposition of nearby } \\
\text { washes? }\end{array}$ & & & \\
\hline e. Are there new drainage channels? & & $\overline{2}$ & \\
\hline f. Change in surrounding vegetation? & & & \\
\hline \multicolumn{4}{|l|}{ 2. Security fence, signs. } \\
\hline $\begin{array}{l}\text { a. Displacement of fences, site markers, boundary markers, or } \\
\text { monuments? }\end{array}$ & & & fencer demaged by havser \\
\hline $\begin{array}{l}\text { b. Have any signs been damaged or removed? } \\
\text { (Number of signs replaced: }\end{array}$ & & & all signs \\
\hline & & & No lacks on gete \\
\hline
\end{tabular}




\section{CAU 426: CACTUS SPRING WASTE TRENCHES, POST-CLOSURE MONITORING CHECKLIST}

3. Waste Unit cover.

a. Is there evidence of settling?

b. Is there cracking?

c. Is there evidence of erosion around the cap (wind or water)?

d. Is there evidence of animal burrowing?

e. Have the site markers been disturbed by man or natural processes?

f. Do natural processes threaten to integrity of any cover or site marker?

g. Other?

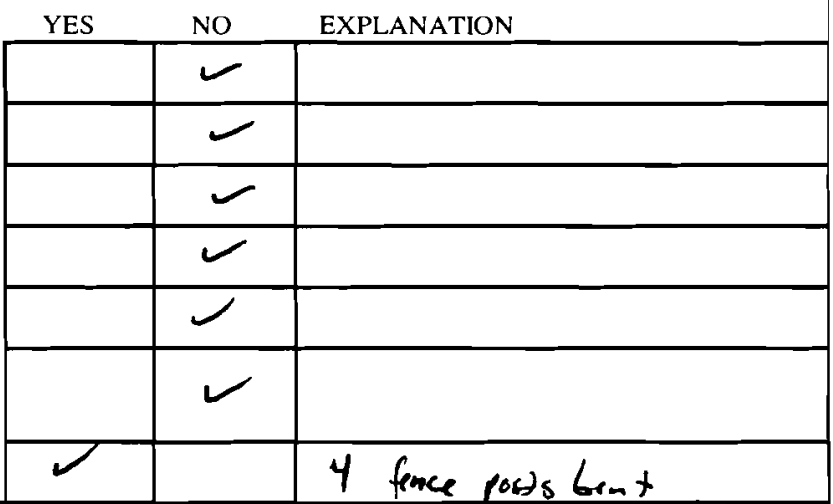

4. Vegetative cover

a. Is perimeter fence or mesh fencing damaged?

b. Is there evidence of horses or rabbits on site?

c. Is organic mulch and/or plants adequate to prevent erosion?

d. Are weedy annual plants present? If yes, are they a problem?

e. Are seeded plant species found on site?

f. Is there evidence of plant mortality?

\begin{tabular}{|l|l|l|}
\hline$\checkmark$ & & 4 force pars bent \\
\hline$\checkmark$ & & horser have ented sit \\
\hline & $\checkmark$ & \\
\hline & $\checkmark$ & \\
\hline$\checkmark$ & & \\
\hline & $\checkmark$ & \\
\hline
\end{tabular}

5. Photo Documentation

a. Has a photo $\log$ been prepared?

c. Number of photos exposed ( 4 )

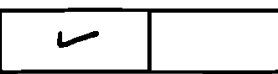

\section{FIELD CONCLUSIONS}

1. Is there an imminent hazard to the integrity of the unit? (Immediate report required)

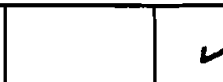

Person/Agency to whom report made

2. Are more frequent inspections required?

3. Are existing maintenance/repair actions satisfactory?

4. Is other maintenance/repair necessary?

5. Is current status/condition of vegetative cover satisfactory?

6. Rationale for field conclusions: (ave in grod candition, fance donage to be repairal.

\section{E. CERTIFICATION}

1 have conducted an inspection of the Cactus Spring Waste Trenches, CAU 426, at the TTR in accordance with the Post-Closure Monitoring Plan (see Closure Report) as recorded on this checklist, attached sheets, field notes, photo logs, and photographs.

Chief Inspector's Signature:

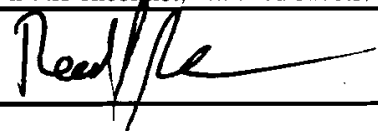

Printed Name: Reed J Poderis

Title: Technical Lead

$$
\text { Date: } 6-10-03
$$




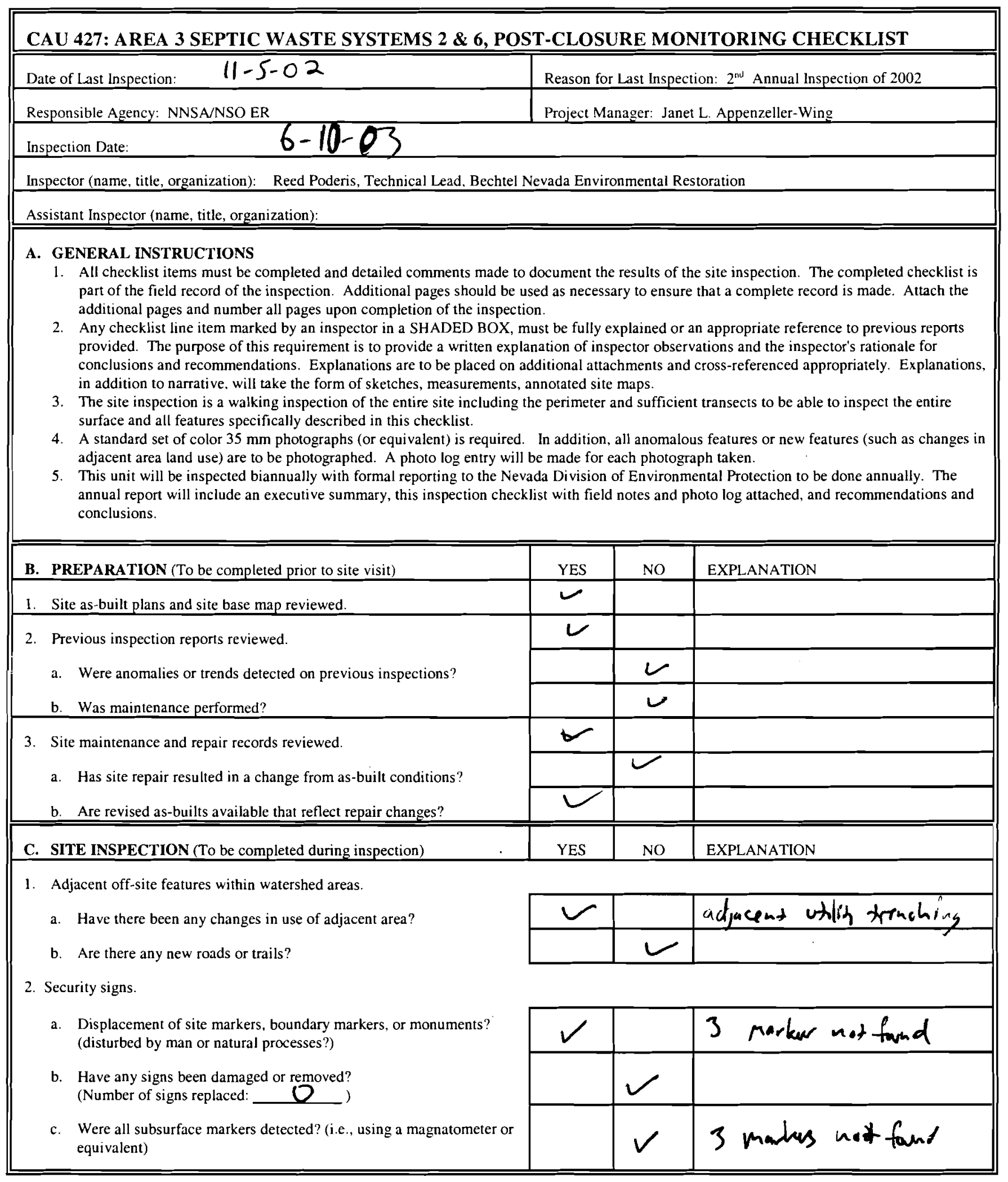




\section{CAU 427: AREA 3 SEPTIC WASTE SYSTEMS $2 \&$ 6, POST-CLOSURE MONITORING CHECKLIST}

3. Soil/aspharlt cover.

a. Is there evidence of settling?

b. Is there cracking?

c. Is there evidence of erosion near use restriction boundaries?

d. Is there evidence of animal burrowing?

e. Is there vegetation?

f. Do natural processes threaten to integrity of any cover or site marker?

g. Is there evidence suggesting unauthorized excavations have taken place?

e. Other?

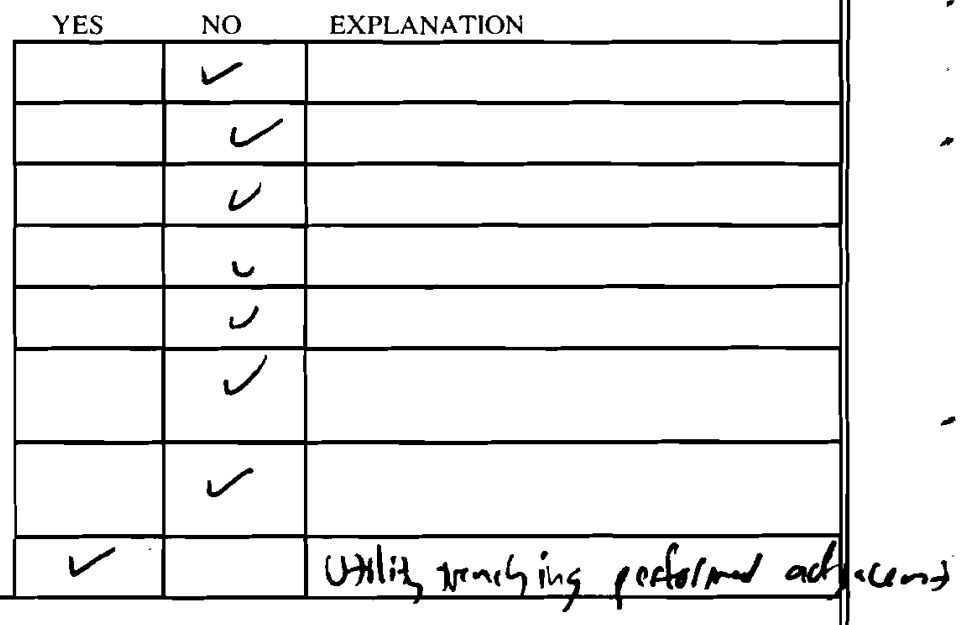

4. Photo Documentation

a. Has a photo log been prepared?

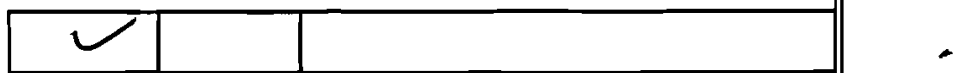

c. Number of photos exposed ( 4 )

\section{FIELD CONCLUSIONS}

1. Is there an imminent hazard to the integrity of the unit? (Immediate report required)

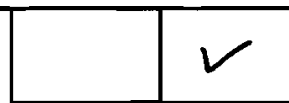

Person/Agency to whom report made

2. Are more frequent inspections required?

3. Are existing maintenance/repair actions satisfactory?

4. Is other maintenance/repair necessary?

5. Rationale for field conclusions: A utlith excauntion trach was corpleted rear the

site. It is not known if ans of the treavatio why writhin the sit bandog

\section{E. Certification}

I have conducted an inspection of the Area 3 Septic Waste Systems $2 \&$ 6, CAU 427, at the TTR in accordance with the Post-Closure Monitoring Plan (see Closure Report) as recorded on this checklist, attached sheets, field notes, photo logs, and photographs.

Chief Inspector's Signature:

Printed Name: Reed J Poderis

Title: Technical Lead

Date: $6-11-03$ 


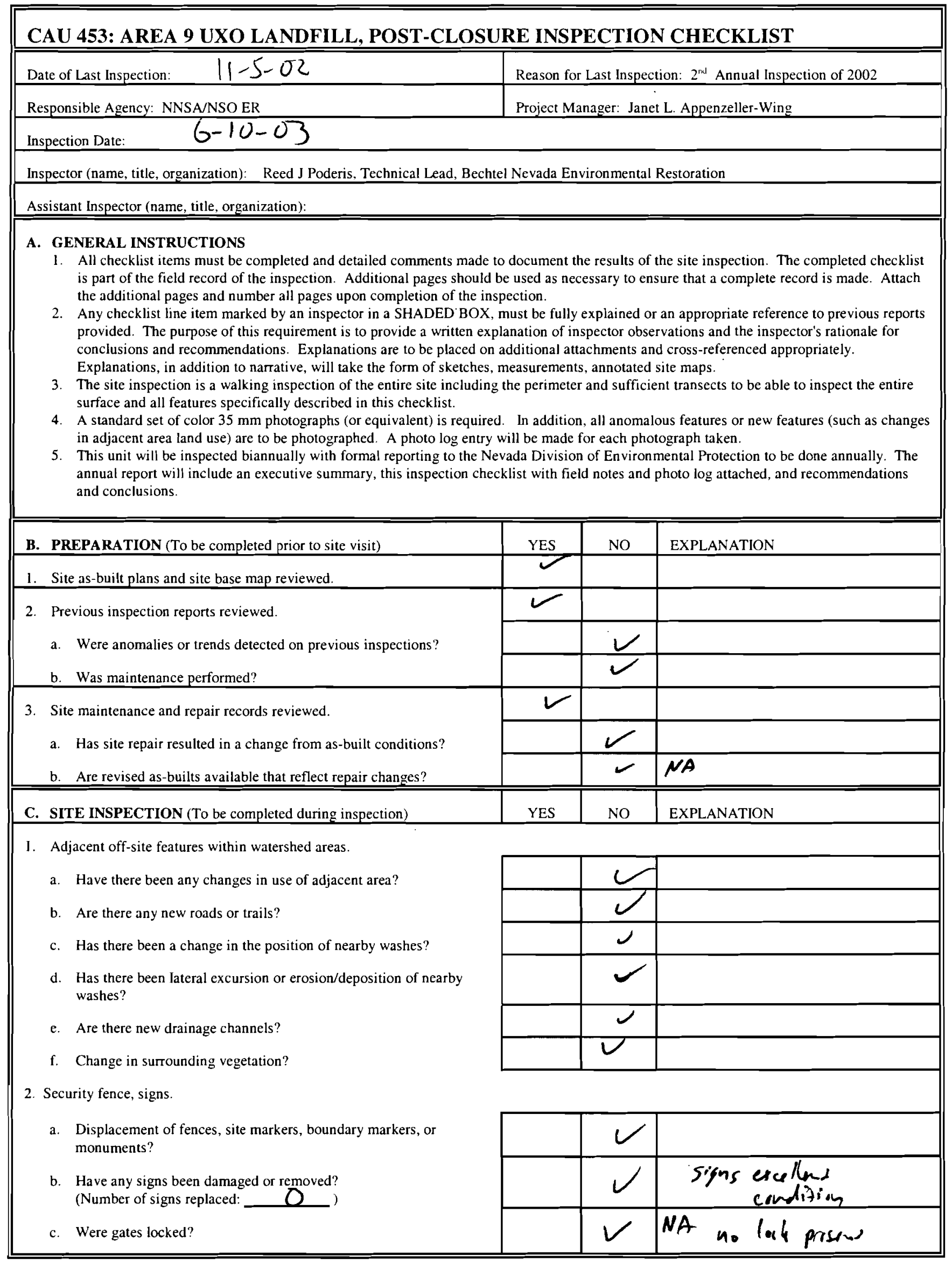




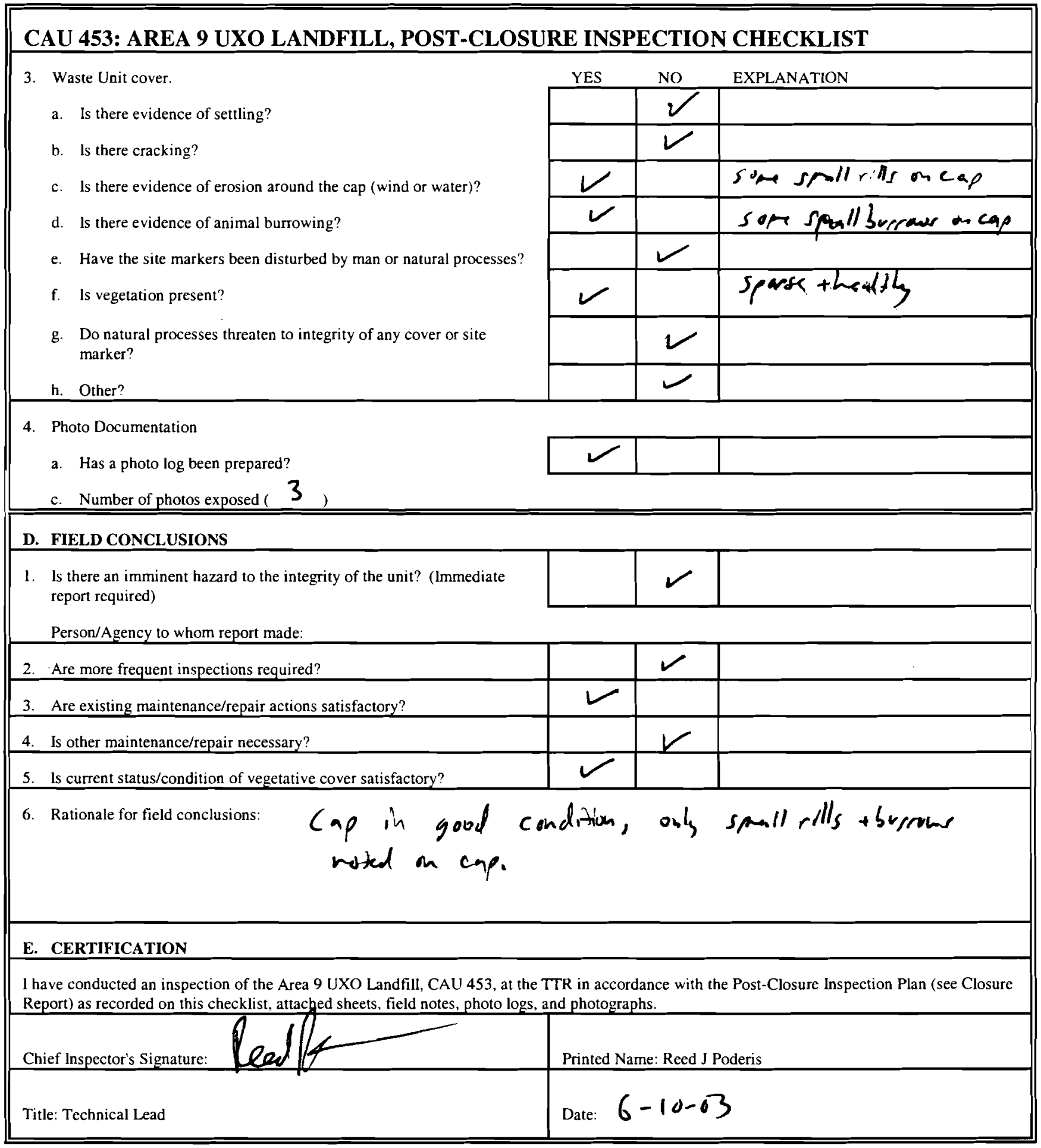


CAU 400: BOMBLET PIT, POST-CLOSURE MONITORING CHECKLIST

\begin{tabular}{|c|c|}
\hline Date of Last Inspection: $10 \mathrm{Jure} 03$ & Reason for Last Inspection: $1^{\prime \prime}$ Annual Inspection of 2003 \\
\hline Responsible Agency: NNSA/NSO ER & Project Manager: Janet L. Appenzeller-Wing \\
\hline \multicolumn{2}{|l|}{ Inspection Date: $\mathrm{C} 3 \mathrm{D}, \mathrm{C} 3$} \\
\hline \multicolumn{2}{|c|}{ Inspector (name, title, organization): Ronald B. Jackson. Task Manager, Bechtel Nevada Environmental Restoration } \\
\hline
\end{tabular}

\section{A. GENERAL INSTRUCTIONS}

1. All checklist items must be completed and detailed comments made to document the results of the site inspection. The completed checklist is part of the field record of the inspection. Additional pages should be used as necessary to ensure that a complete record is made. Attach the additional pages and number all pages upon completion of the inspection.

2. Any checklist line item marked by an inspector in a SHADED BOX, must be fully explained or an appropriate reference to previous reports provided. The purpose of this requirement is to provide a written explanation of inspector observations and the inspector's rationale for conclusions and recommendations. Explanations are to be placed on additional attachments and cross-referenced appropriately. Explanations. in addition to narrative, will take the form of sketches, measurements, annotated site maps

3. The site inspection is a walking inspection of the entire site including the perimeter and sufficient transects to be able to inspect the entire surface and all features specifically described in this checklist.

4. A standard set of color $35 \mathrm{~mm}$ photographs (or equivalent) is required. In addition, all anomalous features or new features (such as changes in adjacent area land use) are to be photographed. A photo log entry will be made for each photograph taken.

5. This unit will be inspected biannually with formal reporting to the Nevada Division of Environmental Protection to be done annually. The annual report will include an executive summary, this inspection checklist with field notes and photo log attached, and recommendations and conclusions.

\begin{tabular}{|c|c|c|c|}
\hline B. PREPARATION (To be completed prior to site visit) & YES & NO & EXPLANATION \\
\hline 1. Site as-built plans and site base map reviewed. & & & \\
\hline \multicolumn{4}{|l|}{ 2. Previous inspection reports reviewed. } \\
\hline a. Were anomalies or trends detected on previous inspections? & & & \\
\hline b. Was maintenance performed? & & & \\
\hline \multirow{2}{*}{$\begin{array}{l}\text { Site maintenance and repair records reviewed. } \\
\text { a. Has site repair resulted in a change from as-built conditions? }\end{array}$} & ' & & \\
\hline & & & \\
\hline b. Are revised as-builts available that reflect repair changes? & & & $V / A$ \\
\hline C. SITE INSPECTION (To be completed during inspection) & YES & NO & EXPLANATION \\
\hline
\end{tabular}

1. Adjacent off-site features within watershed areas.

a. Have there been any changes in use of adjacent area?

b. Are there any new roads or trails?

c. Has there been a change in the position of nearby washes?

d. Has there been lateral excursion or erosion/deposition of nearby washes?

e. Are there new drainage channels?

f. Change in surrounding vegetation?

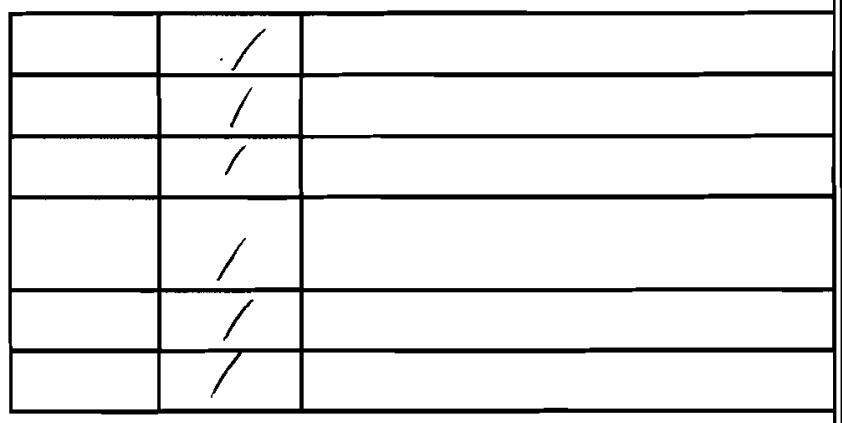

2. Security fence, signs.

a. Displacement of fences, site markers, boundary markers, or monuments?

b. Have any signs been damaged or removed? (Number of signs replaced: )

c. Were gates locked? 


\section{CAU 400: BOMBLET PIT, POST-CLOSURE MONITORING CHECKLIST}

3. Waste Unit cover.

a. Is there evidence of settling?

b. Is there cracking?

c. Is there evidence of erosion around the cap (wind or water)?

d. Is there evidence of animal burrowing?

e. Have the site markers been disturbed by man or natural processes?

f. Do natural processes threaten to integrity of any cover or site marker?

g. Other?

\begin{tabular}{|c|c|c|}
\hline YES & No & EXPLANATION \\
\hline & 1 & \\
\hline & 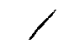 & \\
\hline & Y & \\
\hline$\therefore$ & & Minur ámis la dor feree \\
\hline & 1 & \\
\hline & 1 & \\
\hline & 1 & \\
\hline
\end{tabular}

4. Vegetative cover.

a. is perimeter fence or mesh fencing damaged?

b. Is there evidence of horses or rabbits on site?

c. Is organic mulch and/or plants adequate to prevent erosion?

d. Are weedy annual plants present? If yes, are they a problem?

e. Are seeded plant species found on site?

f. Is there evidence of plant mortality?

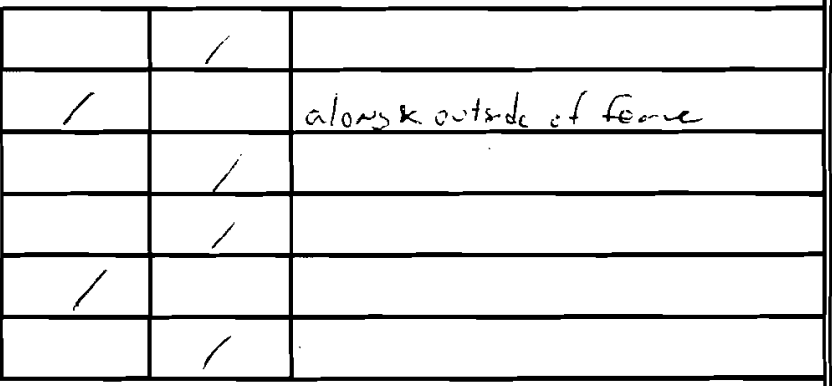

5. Photo Documentation

a. Has a photo log been prepared?

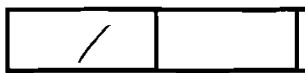

c. Number of photos exposed ( 3 )

\section{FIELD CONCLUSIONS}

1. Is there an imminent hazard to the integrity of the unit? (Immediate report required)

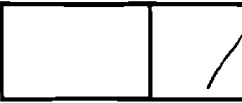

Person/Agency to whom report made:

2. Are more frequent inspections required?

3. Are existing maintenance/repair actions satisfactory?

4. Is other maintenance/repair necessary?

5. Is current status/condition of vegetative cover satisfactory?

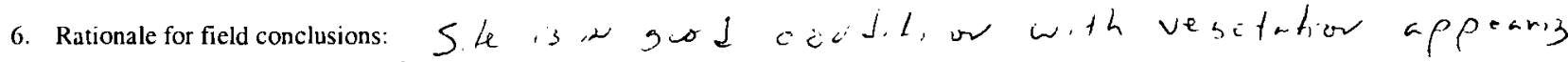

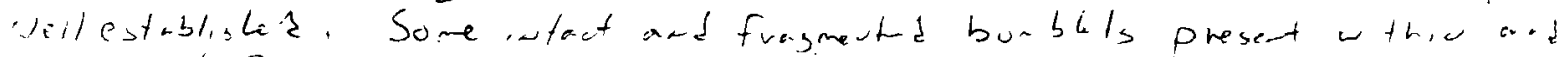
ovis.le of ferce.

\section{E. CERTIFICATION}

I have conducted an inspection of the Bomblet Pit, CAU 400, at the TTR in accordance with the Post-Closure Monitoring Plan (see Closure Report) as recorded on this checklist, attached sheets, field notes, photo logs, and photographs.

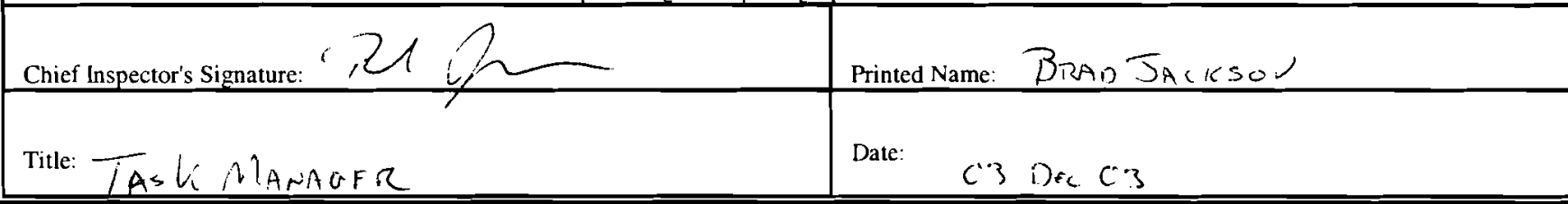


CAU 400: 5 POINTS LANDFILL, POST-CLOSURE MONITORING CHECKLIST

\begin{tabular}{|c|c|}
\hline Date of Last Inspection: $10 \mathrm{Jum} \quad 03$ & Reason for Last Inspection: $1^{\text {st }}$ Annual Inspection of 2003 \\
\hline Responsible Agency: NNSA/NSO ER & Project Manager: Janet L. Appenzeller-Wing \\
\hline \multicolumn{2}{|l|}{ Inspection Date: $\mathrm{C}_{3}$ Des 43} \\
\hline Inspector (name, title, organization): Ronald & I Nevada Environmental Restoration \\
\hline
\end{tabular}

\section{A. GENERAL INSTRUCTIONS}

1. All checklist items must be completed and detailed comments made to document the results of the site inspection. The completed checklist is part of the field record of the inspection. Additional pages should be used as necessary to ensure that a complete record is made. Attach the additional pages and number all pages upon completion of the inspection.

2. Any checklist line item marked by an inspector in a SHADED BOX, must be fully explained or an appropriate reference to previous reports provided. The purpose of this requirement is to provide a written explanation of inspector observations and the inspector's rationale for conclusions and recommendations. Explanations are to be placed on additional attachments and cross-referenced appropriately. Explanations, in addition to narrative, will take the form of sketches, measurements, annotated site maps.

3. The site inspection is a walking inspection of the entire site including the perimeter and sufficient transects to be able to inspect the entire surface and all features specifically described in this checklist.

4. A standard set of color $35 \mathrm{~mm}$ photographs (or equivalent) is required. In addition, all anomalous features or new features (such as changes in adjacent area land use) are to be photographed. A photo log entry will be made for each photograph taken.

5. This unit will be inspected biannually with formal reporting to the Nevada Division of Environmental Protection to be done annually. The annual report will include an executive summary, this inspection checklist with field notes and photo log attached, and recommendations and conclusions.

\begin{tabular}{|c|c|c|c|c|}
\hline B. & PREPARATION (To be completed prior to site visit) & YES & NO & EXPLANATION \\
\hline 1. & Site as-built plans and site base map reviewed. & 1 & & \\
\hline \multirow[t]{3}{*}{2.} & Previous inspection reports reviewed. & & & \\
\hline & a. Were anomalies or trends detected on previous inspections? & & & \\
\hline & b. Was maintenance performed? & & & \\
\hline \multirow[t]{3}{*}{3.} & Site maintenance and repair records reviewed. & & & \\
\hline & a. Has site repair resulted in a change from as-built conditions? & & & \\
\hline & b. Are revised as-builts available that reflect repair changes? & & 。 & $\triangle / A$ \\
\hline C. & SITE INSPECTION (To be completed during inspection) & YES & NO & EXPLANATION \\
\hline
\end{tabular}

1. Adjacent off-site features within watershed areas.

a. Have there been any changes in use of adjacent area?

b. Are there any new roads or trails?

c. Has there been a change in the position of nearby washes?

d. Has there been lateral excursion or erosion/deposition of nearby washes?

e. Are there new drainage channels?

f. Change in surrounding vegetation?

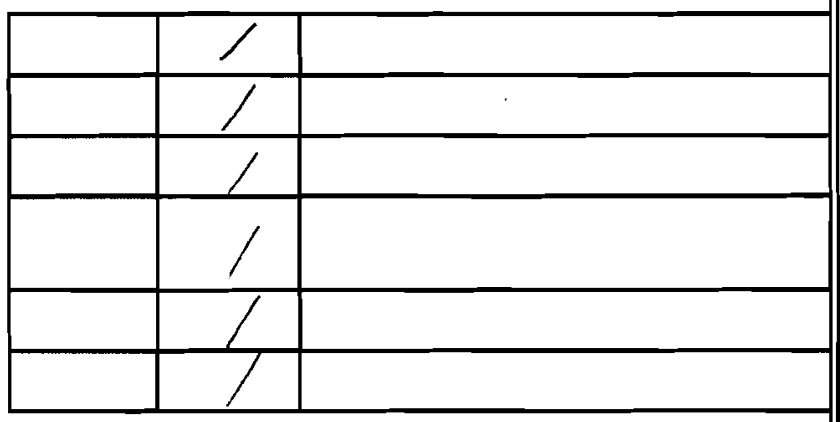

2. Security fence, signs.

a. Displacement of fences, site markers, boundary markers, or monuments?

b. Have any signs been damaged or removed? (Number of signs replaced:

c. Were gates locked?

\begin{tabular}{|l|l|l|}
\hline & $\prime$ & \\
\hline & $/$ & $N_{j} A$ \\
\hline & $/$ & Nolovis veovited \\
\hline
\end{tabular}




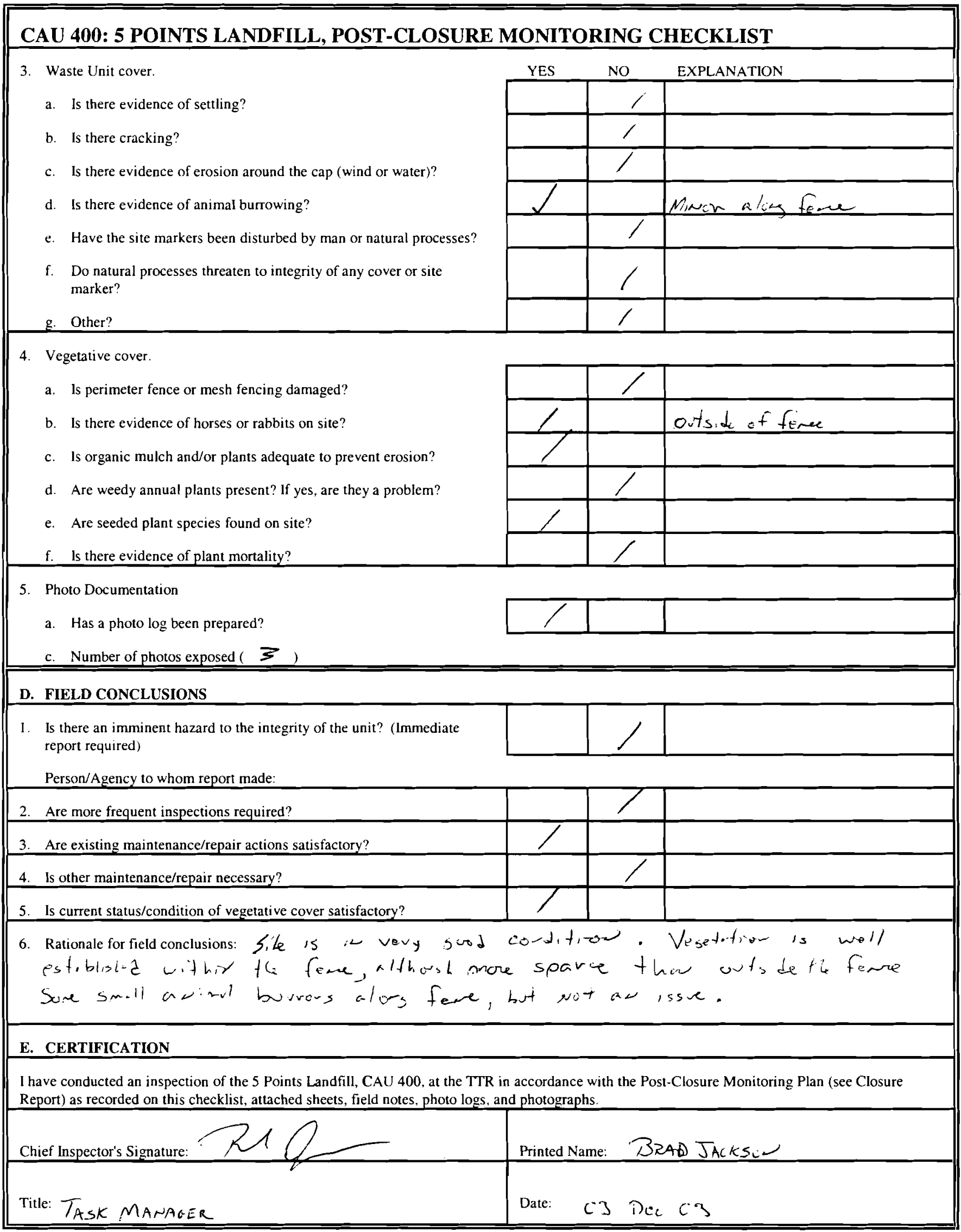




\section{CAU 404: ROLLER COASTER LAGOONS \& N. DISPOSAL TRENCH, POST-CLOSURE MONITORING CHECKLIST}

\begin{tabular}{|c|c|}
\hline Date of Last Inspection: 10 Jure o 3 & Reason for Last Inspection: $1^{\text {*t }}$ Annual Inspection of 2003 \\
\hline Responsible Agency: NNSA/NSO ER & Project Manager: Janet L. Appenzeller-Wing \\
\hline Inspection Date: & \\
\hline
\end{tabular}

\section{A. GENERAL INSTRUCTIONS}

1. All checklist items must be completed and detailed comments made to document the results of the site inspection. The completed checklist is part of the field record of the inspection. Additional pages should be used as necessary to ensure that a complete record is made. Attach the additional pages and number all pages upon completion of the inspection.

2. Any checklist line item marked by an inspector in a SHADED BOX, must be fully explained or an appropriate reference to previous reports provided. The purpose of this requirement is to provide a written explanation of inspector observations and the inspector's rationale for conclusions and recommendations. Explanations are to be placed on additional attachments and cross-referenced appropriately. Explanations. in addition to narrative, will take the form of sketches, measurements, annotated site maps.

3. The site inspection is a walking inspection of the entire site including the perimeter and sufficient transects to be able to inspect the entire surface and all features specifically described in this check list.

4. A standard set of color $35 \mathrm{~mm}$ photographs is required. In addition, all anomalous features or new features (such as changes in adjacent area land use) are to be photographed. A photo log entry will be made for each photograph taken

5. This unit will be inspected biannually with formal reporting to the Nevada Division of Environmental Protection to be done annually. The annual report will include an executive summary, this inspection checklist with field notes and photo log attached, and recommendations and conclusions.

\begin{tabular}{|c|c|c|c|}
\hline B. PREPARATION (To be completed prior to site visit) & YES & NO & EXPLANATION \\
\hline 1. Site as-built plans and site base map reviewed. & & & \\
\hline \multicolumn{4}{|l|}{ 2. Previous inspection reports reviewed. } \\
\hline a. Were anomalies or trends detected on previous inspections? & & & \\
\hline b. Was maintenance performed? & & & \\
\hline \multicolumn{4}{|l|}{ Site maintenance and repair records reviewed. } \\
\hline a. Has site repair resulted in a change from as-built conditions? & & & \\
\hline b. Are revised as-builts available that reflect repair changes? & & & $\checkmark A$ \\
\hline C. SITE INSPECTION (To be completed during inspection) & YES & NO & EXPLANATION \\
\hline \multicolumn{4}{|l|}{ 1. Adjacent off-site features within watershed areas. } \\
\hline a. Have there been any changes in use of adjacent area? & & ' & \\
\hline b. Are there any new roads or trails? & & $\angle$ & \\
\hline c. Has there been a change in the position of nearby washes? & & 1 & \\
\hline $\begin{array}{l}\text { d. Has there been lateral excursion or erosion/deposition of nearby } \\
\text { washes? }\end{array}$ & & & \\
\hline e. Are there new drainage channels? & & $\nearrow$ & \\
\hline f. Change in surrounding vegetation? & & 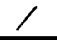 & \\
\hline 2. Security fence, signs. & & & \\
\hline $\begin{array}{l}\text { a. Displacement of fences, site markers, boundary markers, or } \\
\text { monuments? }\end{array}$ & & & \\
\hline $\begin{array}{l}\text { b. Have any signs been damaged or removed? } \\
\text { (Number of signs replaced: }\end{array}$ & & & \\
\hline c. Were gates locked? & & & $t^{\prime}$ ioil Drese. \\
\hline
\end{tabular}




\section{CAU 404: ROLLER COASTER LAGOONS \& N. DISPOSAL TRENCH, POST-CLOSURE MONITORING CHECKLIST}

3. Waste Unit cover.
a. Is there evidence of settling?
b. Is there cracking?
c. Is there evidence of erosion around the cap (wind or water)?
d. Is there evidence of animal burrowing?
e. Have the site markers been disturbed by man or natural processes?
f. Do natural processes threaten to integrity of any cover or site marker?
g. Other?

\begin{tabular}{|c|c|c|}
\hline YES & NO & EXPLANATION \\
\hline & 1 & \\
\hline & ( & \\
\hline & 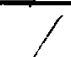 & \\
\hline 1 & & Sm+1! burrows alon feree \\
\hline & $i$ & \\
\hline & y & \\
\hline & i & \\
\hline
\end{tabular}

4. Vegetative cover
a. Is perimeter fence or mesh fencing damaged?
b. Is there evidence of horses or rabbits on site?
c. Is organic mulch adequate to prevent erosion?
d. Are weedy annual plants present? If yes, are they a problem?
e. Are seeded plant species found on site?
f. Is there evidence of plant mortality?

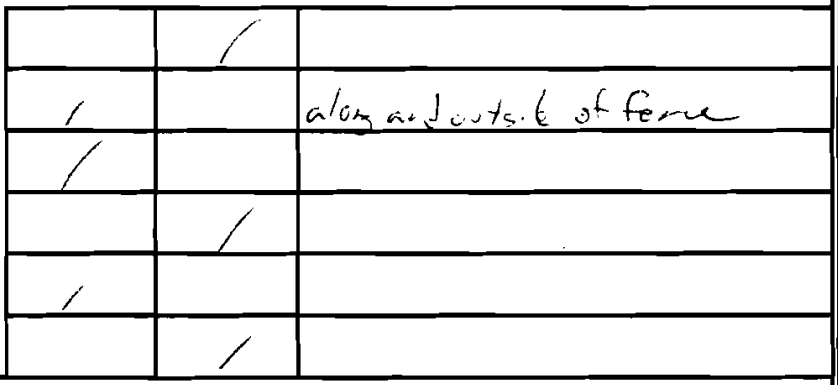

5. Photo Documentation

a. Has a photo log been prepared?

c. Number of photos exposed ( 4 )

\section{FIELD CONCLUSIONS}

1. Is there an imminent hazard to the integrity of the unit? (Immediate report required)

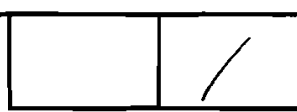

Person/Agency to whom report made:

2. Are more frequent inspections required?

3. Are existing maintenance/repair actions satisfactory?

4. Is other maintenance/repair necessary?

5. Is current status/condition of vegetative cover satisfactory?

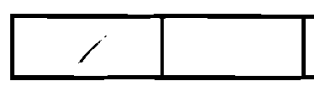


CAU 407: ROLLER COASTER RADSAFE AREA, POST-CLOSURE MONITORING CHECKLIST

\begin{tabular}{||l|l|}
\hline \hline Date of Last Inspection: $10 \mathrm{~J} J \mu \circ 3$ & Reason for Last Inspection: $1^{\text {st }}$ Annual Inspection of 2003 \\
\hline Responsible Agency: NNSA/NSO ER & Project Manager: Janet L. Appenzeller-Wing \\
\hline Inspection Date: 03 Dec 63 & \\
\hline Inspector (name, title, organization): Ronald B. Jackson, Task Manager. Bechtel Nevada Environmental Restoration \\
\hline Assistant Inspector (name, title, organization): $N / A$ \\
\hline \hline
\end{tabular}

\section{A. GENERAL INSTRUCTIONS}

1. All checklist items must be completed and detailed comments made to document the results of the site inspection. The completed checklist is part of the field record of the inspection. Additional pages should be used as necessary to ensure that a complete record is made. Attach the additional pages and number all pages upon completion of the inspection.

2. Any checklist line item marked by an inspector in a SHADED BOX, must be fully explained or an appropriate reference to previous reports provided. The purpose of this requirement is to provide a written explanation of inspector observations and the inspector's rationale for conclusions and recommendations. Explanations are to be placed on additional attachments and cross-referenced appropriately. Explanations, in addition to narrative, will take the form of sketches, measurements, annotated site maps.

3. The site inspection is a walking inspection of the entire site including the perimeter and sufficient transects to be able to inspect the entire surface and all features specifically described in this checklist.

4. A standard set of color $35 \mathrm{~mm}$ photographs is required. In addition, all anomalous features or new features (such as changes in adjacent area land use) are to be photographed. A photo log entry will be made for each photograph taken.

5. This unit will be inspected biannually with formal reporting to the Nevada Division of Environmental Protection to be done annually. The annual report will include an executive summary, this inspection checklist with field notes and photo log attached, and recommendations and conclusions.

\section{B. PREPARATION (To be completed prior to site visit)}

1. Site as-built plans and site base map reviewed.

2. Previous inspection reports reviewed.

a. Were anomalies or trends detected on previous inspections?

b. Was maintenance performed?

3. Site maintenance and repair records reviewed

a. Has site repair resulted in a change from as-built conditions?

b. Are revised as-builts available that reflect repair changes?

\begin{tabular}{|l|c|c|l|}
\hline & YES & NO & EXPLANATION \\
\hline \multirow{3}{*}{} & $/$ & & \\
\cline { 2 - 4 } & $/$ & & \\
\cline { 2 - 4 } & & $/$ & \\
\cline { 2 - 4 } & & $/$ & \\
\cline { 2 - 4 } & & $/$ & \\
\cline { 2 - 4 } & & $/$ & NA \\
\hline & YES & NO & EXPLANATION \\
\hline
\end{tabular}

C. SITE INSPECTION (To be completed during inspection)

1. Adjacent off-site features within watershed areas.

a. Have there been any changes in use of adjacent area?

b. Are there any new roads or trails?

c. Has there been a change in the position of nearby washes?

d. Has there been lateral excursion or erosion/deposition of nearby washes?

e. Are there new drainage channels?

f. Change in surrounding vegetation?

\begin{tabular}{|c|c|l|}
\hline & $/$ & \\
\hline & $/$ & \\
\hline & $/$ & \\
\hline & $/$ & \\
\hline & $/$ & \\
\hline & $i$ & \\
\hline
\end{tabular}

2. Security fence, signs.

a. Displacement of fences, site markers, boundary markers, or monuments?

b. Have any signs been damaged or removed? (Number of signs replaced

c. Were gates locked?

\begin{tabular}{|l|l|l|}
\hline & $/$ & \\
\hline & $j$ & \\
\hline & 1 & \\
\hline
\end{tabular}




\section{CAU 424: AREA 3 LANDFILL COMPLEX, POST-CLOSURE INSPECTION CHECKLIST}

3. Waste Unit cover.

a. Is there evidence of settling?

b. Is there cracking?

c. Is there evidence of erosion around the cap (wind or water)?

d. Is there evidence of animal burrowing?

e. Have the site markers been disturbed by man or natural processes?

f. Is the vegetation on the cover?

g. Do natural processes threaten to integrity of any cover or site marker?

h. Other?

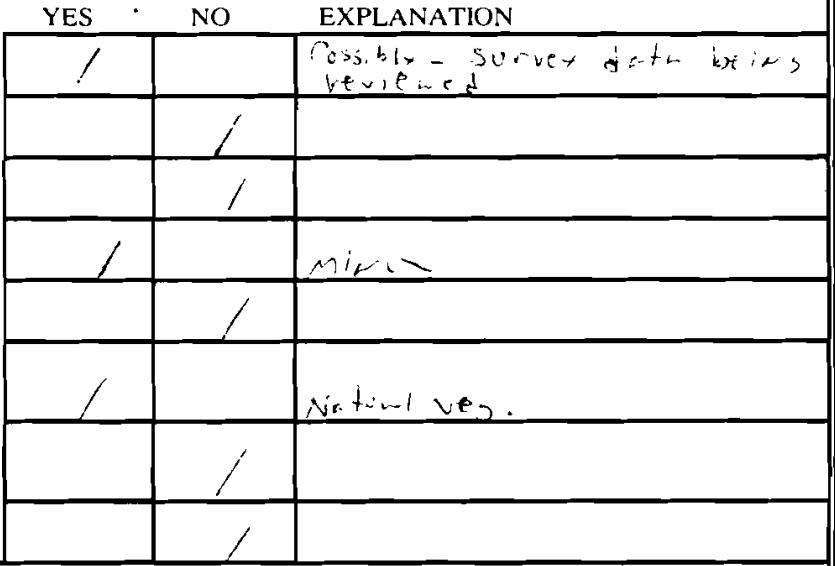

4. Photo Documentation

a. Has a photo log been prepared?

$75+, \operatorname{sen} 20 t+1$

c. Number of photos exposed ( 20 )

\section{FIELD CONCLUSIONS}

1. Is there an imminent hazard to the integrity of the unit? (Immediate report required)

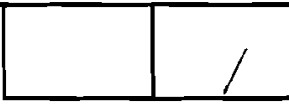

Person/Agency to whom report made

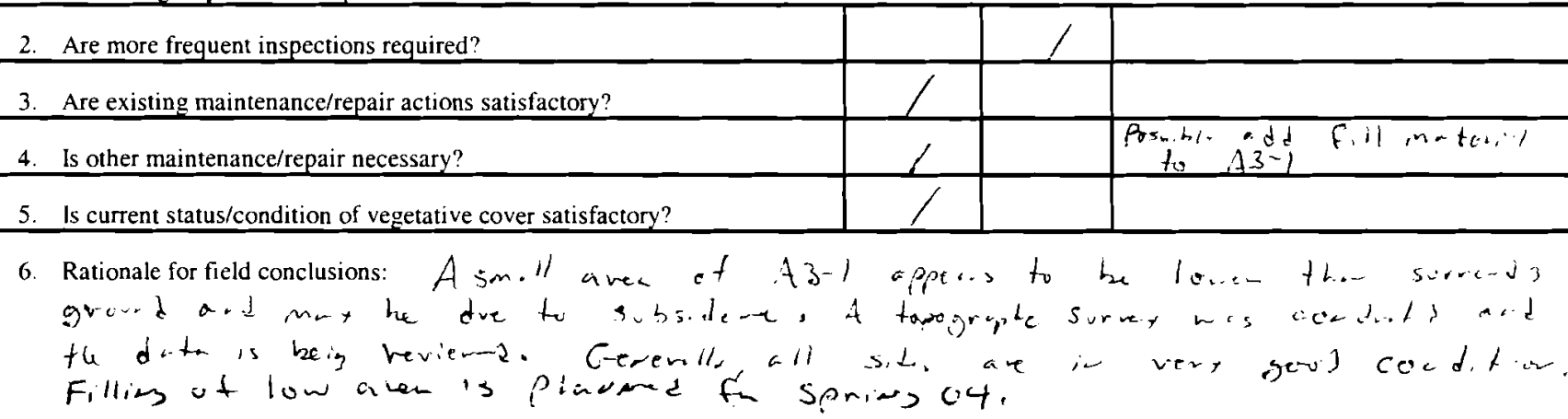

\section{E. CERTIFICATION}

I have conducted an inspection of the Area 3 Landfill Complex, CAU 424, at the TTR in accordance with the Post-Closure Inspection Plan (see Closure Report) as recorded on this checklist, attached sheets, field notes. photo logs, and photographs.

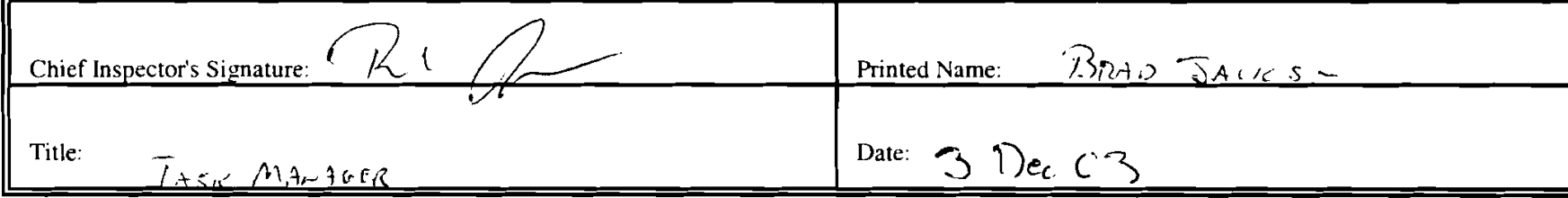


CAU 426: CACTUS SPRING WASTE TRENCHES, POST-CLOSURE MONITORING CHECKLIST

Date of Last Inspection: io Jure 09

Reason for Last Inspection: $1^{\text {st }}$ Annual Inspection of 2003

Responsible Agency: NNSA/NSO ER

Project Manager: Janet L. Appenzeller-Wing

Inspection Date: 03 Dec $C 3$

Inspector (name, title, organization): Ronald B. Jackson, Task Manager, Bechtel Nevada Environmental Restoration

Assistant Inspector (name, title, organization): $\quad$ N/A

\section{A. GENERAL INSTRUCTIONS}

1. All checklist items must be completed and detailed comments made to document the results of the site inspection. The completed checklist is part of the field record of the inspection. Additional pages should be used as necessary to ensure that a complete record is made. Attach the additional pages and number all pages upon completion of the inspection.

3. Any checklist line item marked by an inspector in a SHADED BOX, must be fully explained or an appropriate reference to previous reports provided. The purpose of this requirement is to provide a written explanation of inspector observations and the inspector's rationale for conclusions and recommendations. Explanations are to be placed on additional attachments and cross-referenced appropriately. Explanations, in addition to narrative, will take the form of sketches, measurements, annotated site maps.

4. The site inspection is a walking inspection of the entire site including the perimeter and sufficient transects to be able to inspect the entire surface and all features specifically described in this checklist.

5. A standard set of color $35 \mathrm{~mm}$ photographs (or equivalent) is required. In addition, all anomalous features or new features (such as changes in adjacent area land use) are to be photographed. A photo log entry will be made for each photograph taken

6. This unit will be inspected biannually with formal reporting to the Nevada Division of Environmental Protection to be done annually. The annual report will include an executive summary, this inspection checklist with field notes and photo log attached, and recommendations and conclusions.

\begin{tabular}{|c|c|c|c|}
\hline B. PREPARATION (To be completed prior to site visit) & YES & NO & EXPLANATION \\
\hline 1. Site as-built plans and site base map reviewed. & 1 & & \\
\hline \multirow{3}{*}{$\begin{array}{l}\text { Previous inspection reports reviewed. } \\
\text { a. Were anomalies or trends detected on previous inspections? }\end{array}$} & $\angle$ & & \\
\hline & & & \\
\hline & & 1 & \\
\hline \multirow{3}{*}{$\begin{array}{l}\text { Site maintenance and repair records reviewed. } \\
\text { a. Has site repair resulted in a change from as-built conditions? }\end{array}$} & 1 & & \\
\hline & & 7 & \\
\hline & & & Si/A \\
\hline C. SITE INSPECTION (To be completed during inspection) & YES & NO & EXPLANATION \\
\hline
\end{tabular}

1. Adjacent off-site features within watershed areas.

a. Have there been any changes in use of adjacent area?

b. Are there any new roads or trails?

c. Has there been a change in the position of nearby washes?

d. Has there been lateral excursion or erosion/deposition of nearby washes?

e. Are there new drainage channels?

f. Change in surrounding vegetation?

\begin{tabular}{|l|c|l|}
\hline & $/$ & \\
\hline & 1 & \\
\hline & $/$ & \\
\hline & 1 & \\
\hline & 1 & \\
\hline & 1 & \\
\hline
\end{tabular}

2. Security fence, signs.

a. Displacement of fences, site markers, boundary markers, or monuments?

b. Have any signs been damaged or removed? (Number of signs replaced:

c. Were gates locked?

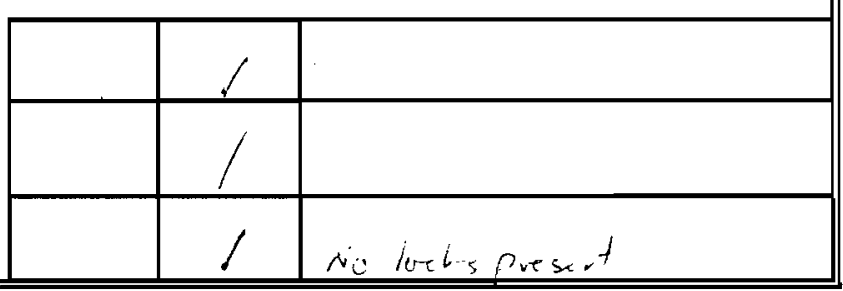




\section{CAU 426: CACTUS SPRING WASTE TRENCHES, POST-CLOSURE MONITORING CHECKLIST}

3. Waste Unit cover

a. Is there evidence of settling?

b. Is there cracking?

c. Is there evidence of erosion around the cap (wind or water)?

d. Is there evidence of animal burrowing?

e. Have the site markers been disturbed by man or natural processes?

f. Do natural processes threaten to integrity of any cover or site marker?

g. Other?

\begin{tabular}{|c|c|c|}
\hline YES & NO & EXPLANATION \\
\hline & & \\
\hline & 1 & \\
\hline$\angle$ & & mirn ale, ferce \\
\hline & 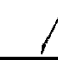 & \\
\hline & 1 & \\
\hline & / & \\
\hline
\end{tabular}

4. Vegetative cover.

a. Is perimeter fence or mesh fencing damaged?

b. Is there evidence of horses or rabbits on site?

c. Is organic mulch and/or plants adequate to prevent erosion?

d. Are weedy annual plants present? If yes, are they a problem?

e. Are seeded plant species found on site?

f. Is there evidence of plant mortality?

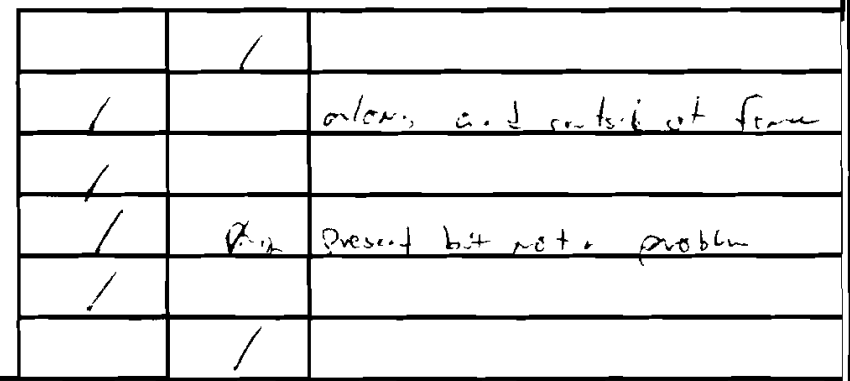

5. Photo Documentation

a. Has a photo log been prepared?

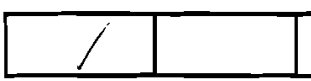

c. Number of photos exposed ( 4$)$

\section{FIELD CONCLUSIONS}

1. Is there an imminent hazard to the integrity of the unit? (Immediate report required)

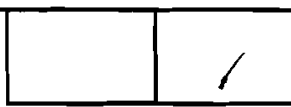

Person/Agency to whom report made

2. Are more frequent inspections required?

3. Are existing maintenance/repair actions satisfactory?

4. Is other maintenance/repair necessary?

5. Is current status/condition of vegetative cover satisfactory?

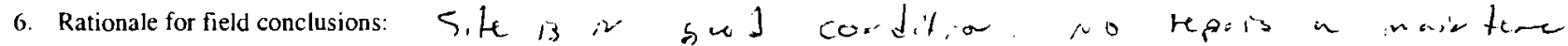

wecessiny. Damaged fercias wited in Jume 03 has beer vepaind.

\section{E. CERTIFICATION}

I have conducted an inspection of the Cactus Spring Waste Trenches, CAU 426, at the TTR in accordance with the Post-Closure Monitoring Plan (see Closure Report) as recorded on this checklist. attached sheets, field notes, photo logs. and photographs.

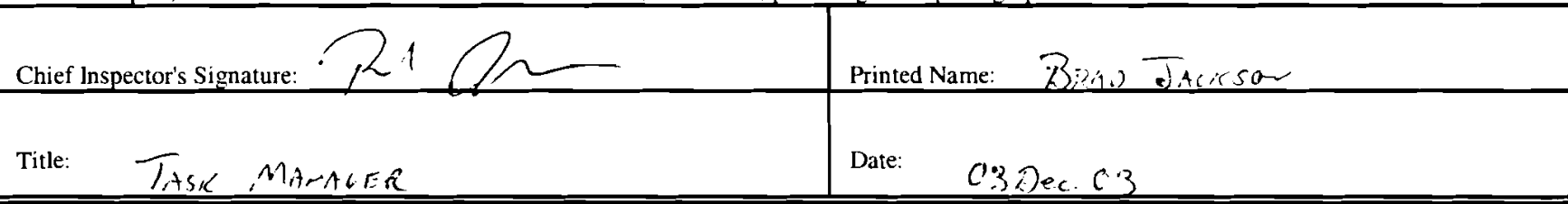




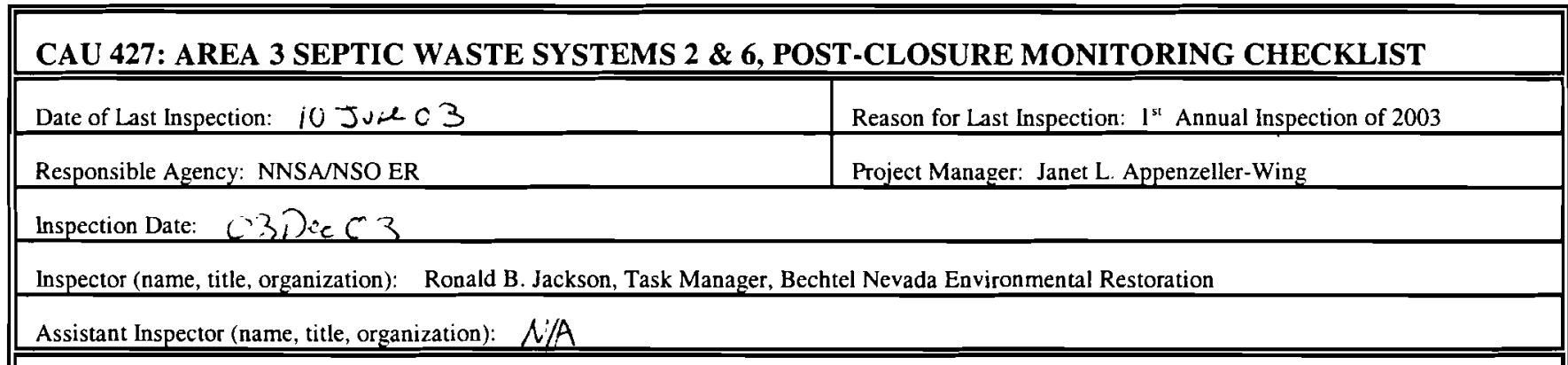

\section{A. GENERAL INSTRUCTIONS}

1. All checklist items must be completed and detailed comments made to document the results of the site inspection. The completed checklist is part of the field record of the inspection. Additional pages should be used as necessary to ensure that a complete record is made. Attach the additional pages and number all pages upon completion of the inspection.

2. Any checklist line item marked by an inspector in a SHADED BOX, must be fully explained or an appropriate reference to previous reports provided. The purpose of this requirement is to provide a written explanation of inspector observations and the inspector's rationale for conclusions and recommendations. Explanations are to be placed on additional attachments and cross-referenced appropriately. Explanations, in addition to narrative, will take the form of sketches, measurements, annotated site maps.

3. The site inspection is a walking inspection of the entire site including the perimeter and sufficient transects to be able to inspect the entire surface and all features specifically described in this checklist.

4. A standard set of color $35 \mathrm{~mm}$ photographs (or equivalent) is required. In addition, all anomalous features or new features (such as changes in adjacent area land use) are to be photographed. A photo log entry will be made for each photograph taken.

5. This unit will be inspected biannually with formal reporting to the Nevada Division of Environmental Protection to be done annually. The annual report will include an executive summary, this inspection checklist with field notes and photo log attached, and recommendations and conclusions.

\begin{tabular}{|l|c|c|c||}
\hline \hline B. PREPARATION (To be completed prior to site visit) & YES & NO & EXPLANATION \\
\hline 1. Site as-built plans and site base map reviewed. & / & & \\
\hline 2. Previous inspection reports reviewed. & & & \\
a. Were anomalies or trends detected on previous inspections? & & & \\
b. Was maintenance performed? & & & \\
\hline 3. Site maintenance and repair records reviewed. & & & \\
a. Has site repair resulted in a change from as-built conditions? & & & \\
b. Are revised as-builts available that reflect repair changes? & & & L//A \\
\hline \hline C. SITE INSPECTION (To be completed during inspection) & YXXLANATION \\
\hline
\end{tabular}

I. Adjacent off-site features within watershed areas.

a. Have there been any changes in use of adjacent area?

b. Are there any new roads or trails?

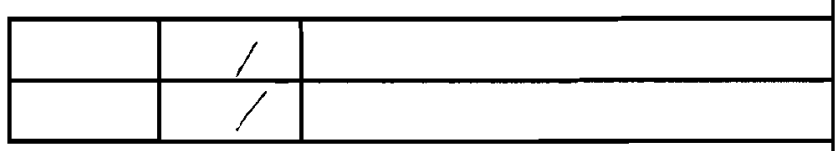

2. Security signs.

a. Displacement of site markers, boundary markers, or monuments? (disturbed by man or natural processes?)

b. Have any signs been damaged or removed? (Number of signs replaced: ___

c. Were all subsurface markers detected? (i.e., using a magnatometer or equivalent)

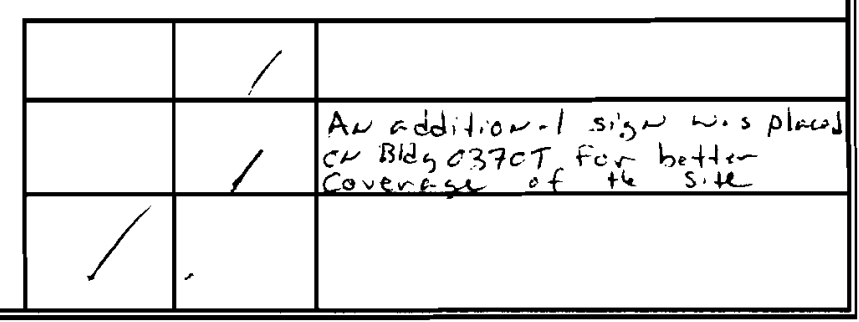




\section{CAU 427: AREA 3 SEPTIC WASTE SYSTEMS 2 \& 6, POST-CLOSURE MONITORING CHECKLIST}

3. Soil/aspharlt cover.

a. Is there evidence of settling?

b. Is there cracking?

c. Is there evidence of erosion near use restriction boundaries?

d. Is there evidence of animal burrowing?

e. Is there vegetation?

f. Do natural processes threaten to integrity of any cover or site marker?

g. Is there evidence suggesting unauthorized excavations have taken place?

e. Other?

\begin{tabular}{|c|c|c|}
\hline YES & \multicolumn{1}{l|}{ NO } & \multicolumn{1}{l|}{ EXPLANATION } \\
\hline & 1 & \\
\hline & $/$ & \\
\hline & $/$ & \\
\hline & $/$ & \\
\hline & $/$ & \\
\hline & $/$ & \\
\hline & $/$ & \\
\hline & $/$ & \\
\hline
\end{tabular}

4. Photo Documentation

a. Has a photo log been prepared?

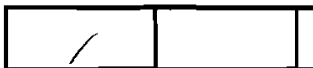

c. Number of photos exposed ( 7 )

\section{FIELD CONCLUSIONS}

1. Is there an imminent hazard to the integrity of the unit? (Immediate report required)

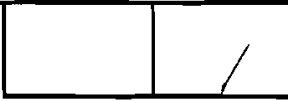

Person/Agency to whom report made

2. Are more frequent inspections required?

3. Are existing maintenance/repair actions satisfactory?

4. Is other maintenance/repair necessary?

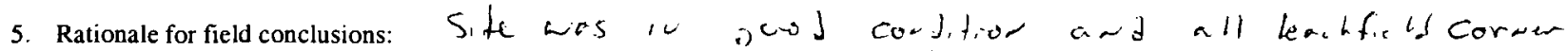

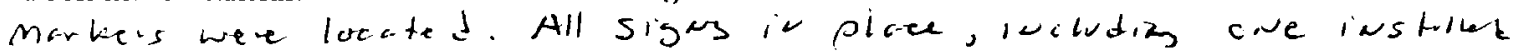
ou Bldin 0307T in Arso3.

\section{E. CERTIFICATION}

I have conducted an inspection of the Area 3 Septic Waste Systems $2 \& 6$, CAU 427, at the TTR in accordance with the Post-Closure Monitoring Plan (see Closure Report) as recorded on this checklist, attached sheets, field notes, photo logs, and photographs.

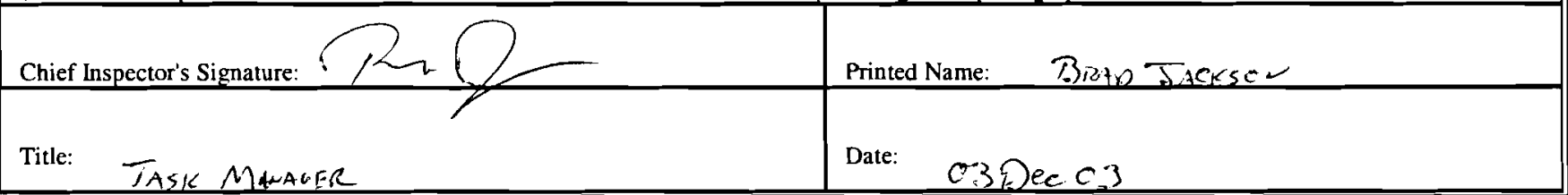




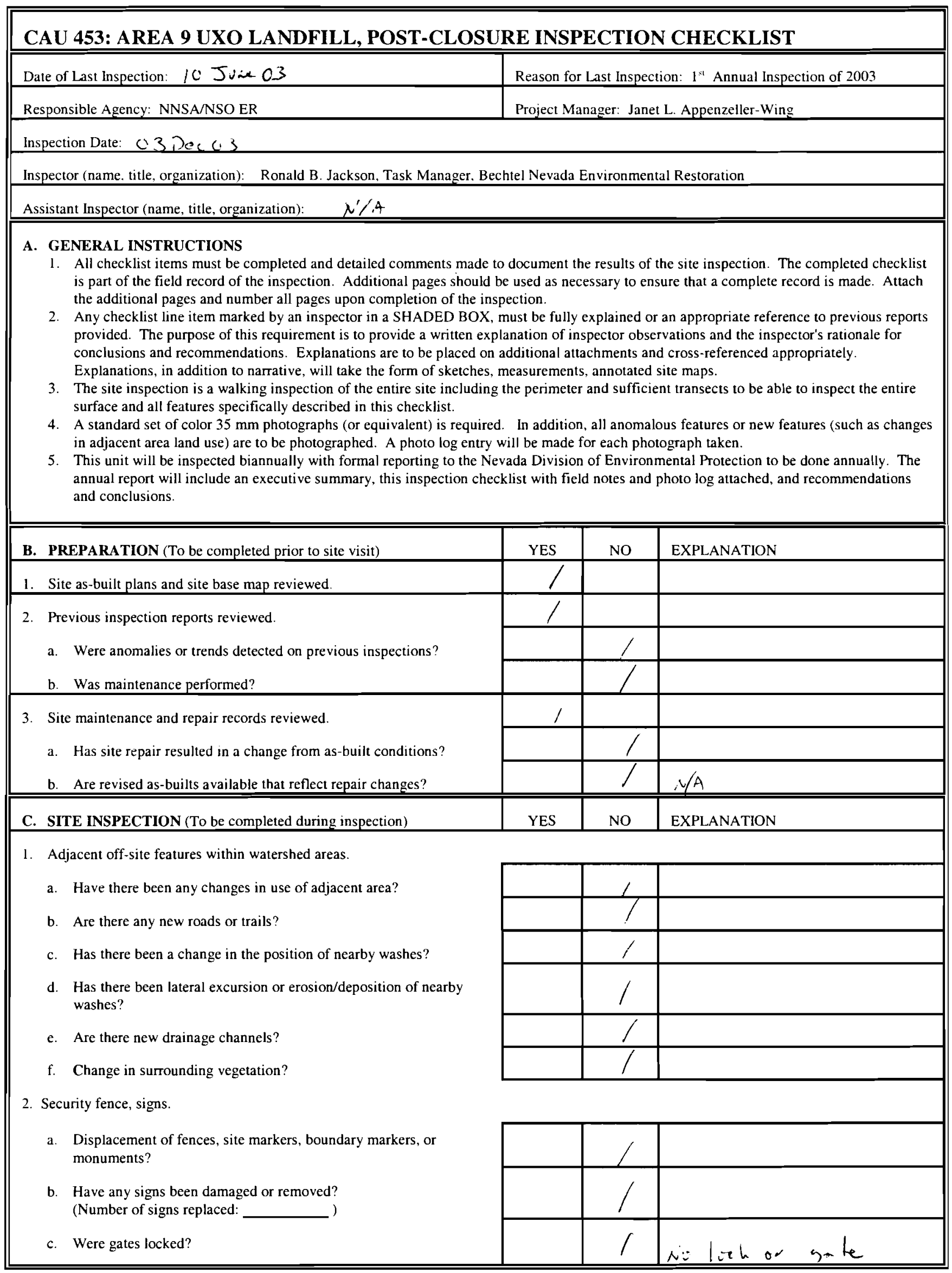




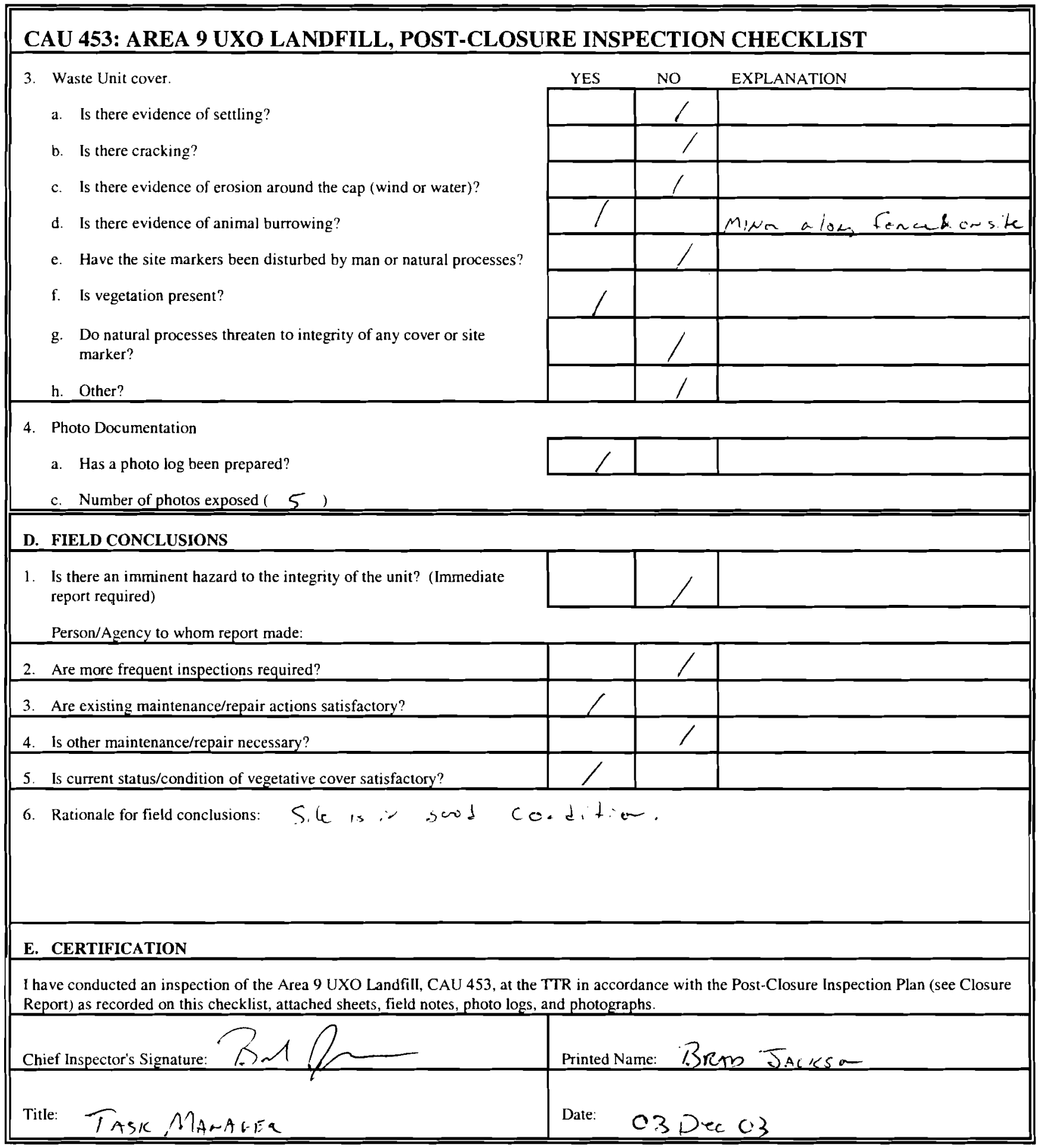


Revision: 0

Date: April 2004

\section{ATTACHMENT C}

\section{FIELD NOTES}


2003 Post-Closure Inspection Report

Revision: 0

Date: April 2004

\section{THIS PAGE INTENTIONALLY LEFT BLANK}


TITLE

Work continued from Page 57
PROJECT NO. BOOK NO.

59

Site visits with Bad Judean, Kevin Cobble, t Ted (NDE)

CAV 427

37. $78610 \quad-116.75712$

marks removal for $N$ side of $3-70 \mathrm{~T} / 104$

5 no signs either an this side

3 Marls missing to ml neal to rehab redpadere

other sit er CAN $410 \quad 37.66739 \quad-116.67062$

10

15

20

25 
32 PROJECT NO. TTR PCl

BOOK NO.

TITLE

Work continued from Page N/A

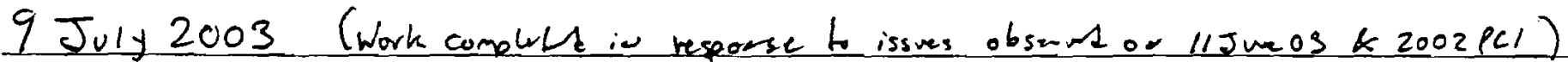

CAU 424 - stamp CUR coordinates \& topo survey A-3.1\&A.3-4

replace morrmot remowd during CAV 490 closure at A3-8

CAV 427 - minor mair terarce of subsurfor mourmert cover rock

5 ard collect measuemerts fa foture irspections.

0791 - Revier scope ot wank aud coudnt site vizit with Survefas

0927 - Surveyors besie stampiz CAV 424 monrmedt, with LUR coordiowts from the CR. As at-greh morvmort at LF cell $A 3-8$ is veplated. The mownert was vemored duries closure of CAV49Q becare it was locotul withir ar aven of TPH-Impals So. 1

1425 - Survex cue has cumpleth strpig CUR coovdidarl. 15 or morumerls acd now besirs topoorgehe survey of LFcells A3-1 \& A3-4. E-W traseseets an rar across the LF cells to collect elerrtion drte to be uses to construct tupugraphre coutor mapsard evoluate potertiol subsidece.

201607 . Survey of CAVA24 A3-1K A3.4 is cumplele a-2 work besizs at CAV 427. Additiond red rock is addre to betta mark locetioses of subsurfer learhfirid marken.

Distame measuremerts are male acd recouded fo earh lewhfirld marka to adjacert struatures.

${ }^{25} 1712$ - wak complele-CAV427. excouction nea-B1dz0307T is outsid LUR.

wm.scientificbindery88yrs.com

sicorutues

DISCLOSED TO AND UNDERSTOOD BY
EOR
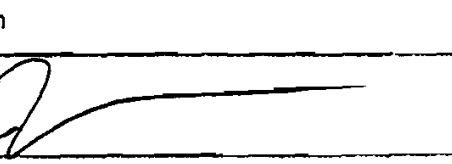

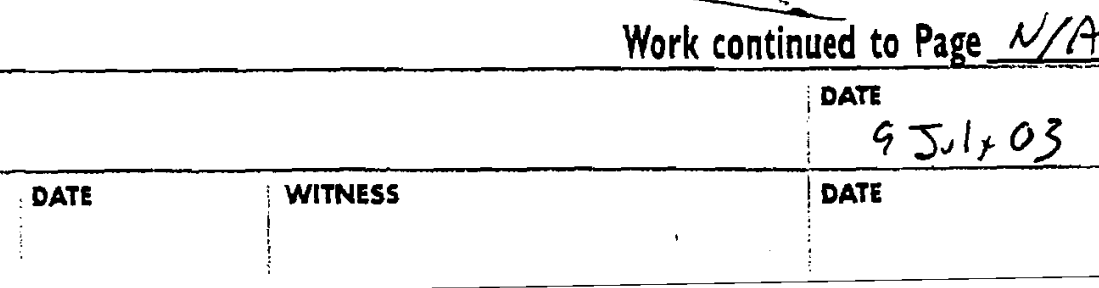

Work continued to Page $N / A$

DATE

$45 \mathrm{Su}+03$ 
TITLE

Work continued from Page 0

$1 / 3$

03 Dec 03
PROJECT NO.

BOOK NO.

81

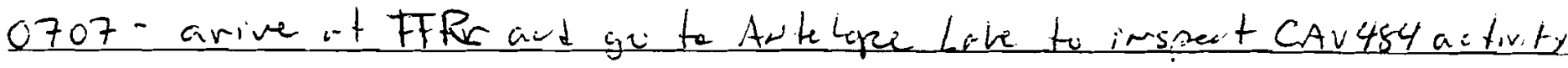
UxU-Red surveys ave in proguss or Antelupe LAKE and yecphysizal Surveys am inprogress cor Brewpes lake 50903 - CAV 407 PCi

site is geverull, in goud cundition, very miner vegetation is presert outle cover der to repairs compledi 2002 . The ferce ard signs cive

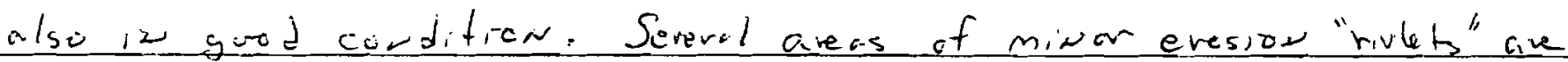
presert co the edise ard siuoed margir of the cover. The evosizer

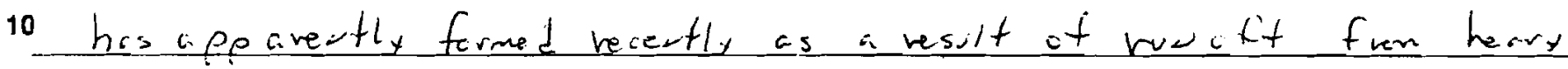
rain is Oct-Nov 2003 . The effects of run off wotar acd evesior ave being compound by the liak of vegetetion on the Cover. Propese a.polyig seed ard nulich tu civen.

0932 - CAV $404 P C 1$

15 The site apperrs to ke in vory goud coudition with vegetation well establistad or the soil covan. No avers of evosice or large burrows are presert. The ferce is in gorod coudition ard the site is well secmed No vepairs or mair tewarce ak vecessing.

${ }^{20} 0057-\operatorname{CAV} 426$ PCI

The site is in gced cordition. Vegotatior is well estoblishd within the force and then are no awes of domaze in evosionoutlcoun. The ferce is in gurd condition with Severul smoll-arimol burrous ovesert inlon the fearce-lia 25 No repain or mainterare are recessary.

$$
1221 \text { - CAV } 400
$$

Five-Powls LF. The ferce was introt $a_{0}$ d vesetiotion is we ll esteblished attle site, althoush vesetritio is less downe thar outs.te th feras

inmw.scientificbindery88yrs.com

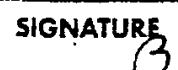

Work continued to Page 82

DISCLOSED TO AND UNBERSTOOD BY

DATE

WITNESS
DATE

03 Dec 03

$\mathrm{B} 200 \mathrm{PH}$ (6) 
82 PROJECT NO. TTRPCI

BOOK NO.

TITLE

Work continued from Page 81

$2 / 3$

CAV 400 contirued

Bomblet Pit - Site s in ojed comdition. The fence is intiot oud vesetation is well estiblizhad, al thaven less derie thar outside of the ferce line. Nunerous intart bomblits and bu blet firameots ave present withiz acd outside the ferce. ONe bomblet frasmeat apperes to bae ow istat charge 1257 - CAV 453 PCI

The site is in goid cordition. Fencing ard signase are lutort ard ave in jood coudition. All merumerts are in geod cordition ard thime ave wo moticeble avers of subsiderce at the site. Severol smill-medium size burrow ave presert along the fewce ard a jock robit wis prese-t withir the ferce. No vepairs or moir tecarce are requived ot this site.

$1332-C A V^{\prime} 424 P C 1$

A3-2-All morvments ave intart and sigrouge is isplome ard is in gool cojitior. Ne aves of subsidere or domage weve noted.

A3-1 - All merumerts are intact and siguage is is place and is ingord cordition. Ar anean alory the east pertion if the site is topegraphicolly lower the the hest of fle site and surrouding aver. This has heed coefirmed by a topojraphe surves

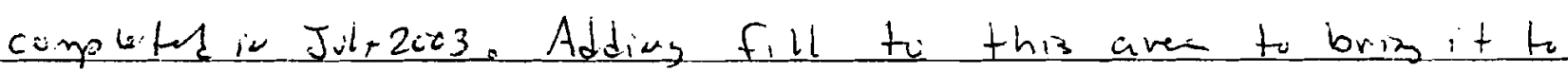

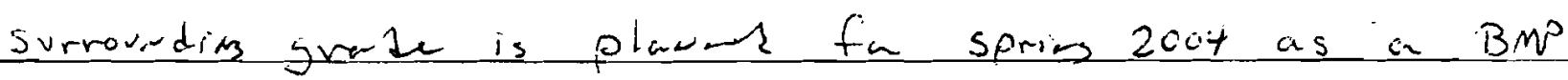
to prevert stardiglfordiez wioten ova the cell.

A3-6. All nowermests ave irtiot ard siswane is ir place ardisnged cordition. No avers if subsidere o damobe were roted.

www.scientificbindery8Byrs.com

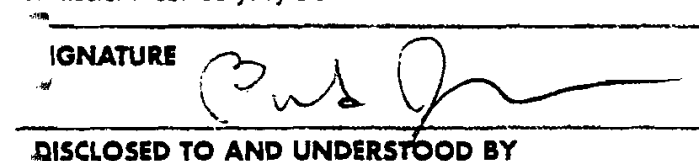

Work continued to Page 83

DATE

03 Dec 03

WITNESS

DATE 
TITLE

Work continued from Page $82 \quad 3 / 3$
PROJECT NO. TTR,PCi BOOK NO.

A3-8 - All monumerts are intact and Signowe is inslace and is in good couditio. No aveas of subsidere on damane were roted. The south portion of the site is withir a vevly cherted RinA.

53-4. All monumects ave intact and siguase is inolace ard is

in geod conditior. Aw aven in the south portion of the sile

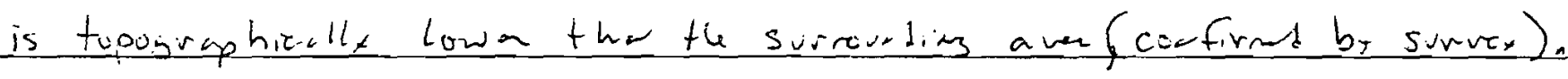

Adding fill to this aven is plaous fin serion 2004.

A3-5 - All monvmerts ave intact and signize is rolice and ${ }^{10}$ is in jeod corditior. No avers of subsiderce andomage roter,

A3-3. All morumerts ave intart aod sigsing is ieplace and is in guod coodition. No avers of subsidera a domase noted.

A 3-7 - No inspection requived

1512 - CAV $427 \mathrm{PCI}$

15 The corvers of all leachfields were located by visul inspection (red rock marks each subsurfor manka location). All use vestrict out signs ave pheseut and are in good coudition. Ar additionnl sis 2 was instrlled or Bids $0370 \mathrm{~T}$ in Ausust 03 to clavify the locotion of buried leachfield woste it 20 this aven. Site is in aecod cordition.

1607 - CAV 487 (Thurdenweil site)

Thi3 GAV is not currestle ireteds is the TIR PCI veavimemert. NNSA requezted the site to he briefly inspected. Work is is proguess to hevize the CADD/CR to irewhe inspections.

25 - Two sigus weve located int the Thuederwell sile to mark aveis of buriel waste. Buth siges howe beer tor dowe by horses ard ore Sigo does not appem to be in the convect location fa th LUR.

www.scientificbindery88yrs.com

SIGNATURE

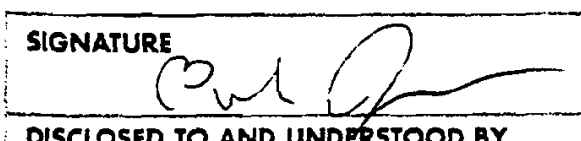

Work continued to Page

DATE

03 Dec 03

8 
PROJECT NO. CALL $407 / 425$ Rquirs95

Work continued from Page N/A CAU 407 Roller Coaster Radial No. Repairs

Highs clouds, 805 ; light winds from the SE.

Tailgate Satiety briefing guin at BN offer. Topics included

5 PPE - steed toes, salt, glasses, wonk gloves, work cloths

teat Stress - dink liyinids take rot breach s when needed.

Slip Ti \& fall - uneven ground

Pinch Points, Cods - ween work gloves,

- scope of work

Repain/reinthe fence live

Repair minos erosion rills on cover side slopes

Personal

5 Kevin Campbell - BNER TL

Don Cox - sue super

Randi Bridges - Iron Worker

Kent Thomas - Ir Woven

Pam Selvato - RCT

Gene Howard - Laborer

13100 Got BN Blind Aenctratien Permit said by Gerry Whiten of Westinghouse13:40 Fence in good shape. The se ad sw fence support conner fo we reinforced with new tee -pests and rewiring by iron washers.

25

1350 Cover rills being hand badefilled by labret Rills present on the south, east is north side slopes Fill taken from stock pile outside of fence $R G$ cleared all ace ss to cover work area Reading $4 / \mathrm{mrem}$

1415 Fem er and cover repairs complete. Work continued to Page If

SIGNATURE

$$
{ }^{\text {DATE }} 7 / 16 / 03
$$

DISCLOSED TO AND UNDERSTOOD BY

DATE

WITNESS

DATE 
96

PROJECT NO. CAL $407 / 4=6$

Work continued from Page 95 4072 426 Repair Work BOOK NO.

Visitors arrive on site 1415 bevin tailgate safety ad so ope of work.

Keven Cobble

Brad Jackson

Michel aulic

Heather kImonos

ser Visetion depart site

20 Depart 407 for 426. Cactus Spring Waste Trenches

- RCT Departs for NTS

1435 Amis of CAn 426 cactus spring Wast Trance

510 Replace on tee -pret and repaired two breaks in south fem

hins

-520 Repairs complete. Depart ste for Area 3.

1600 phoned Matrix moms with daily report

1605 Deport $\pi R$ Area 3 for Lar legate

Jest Line

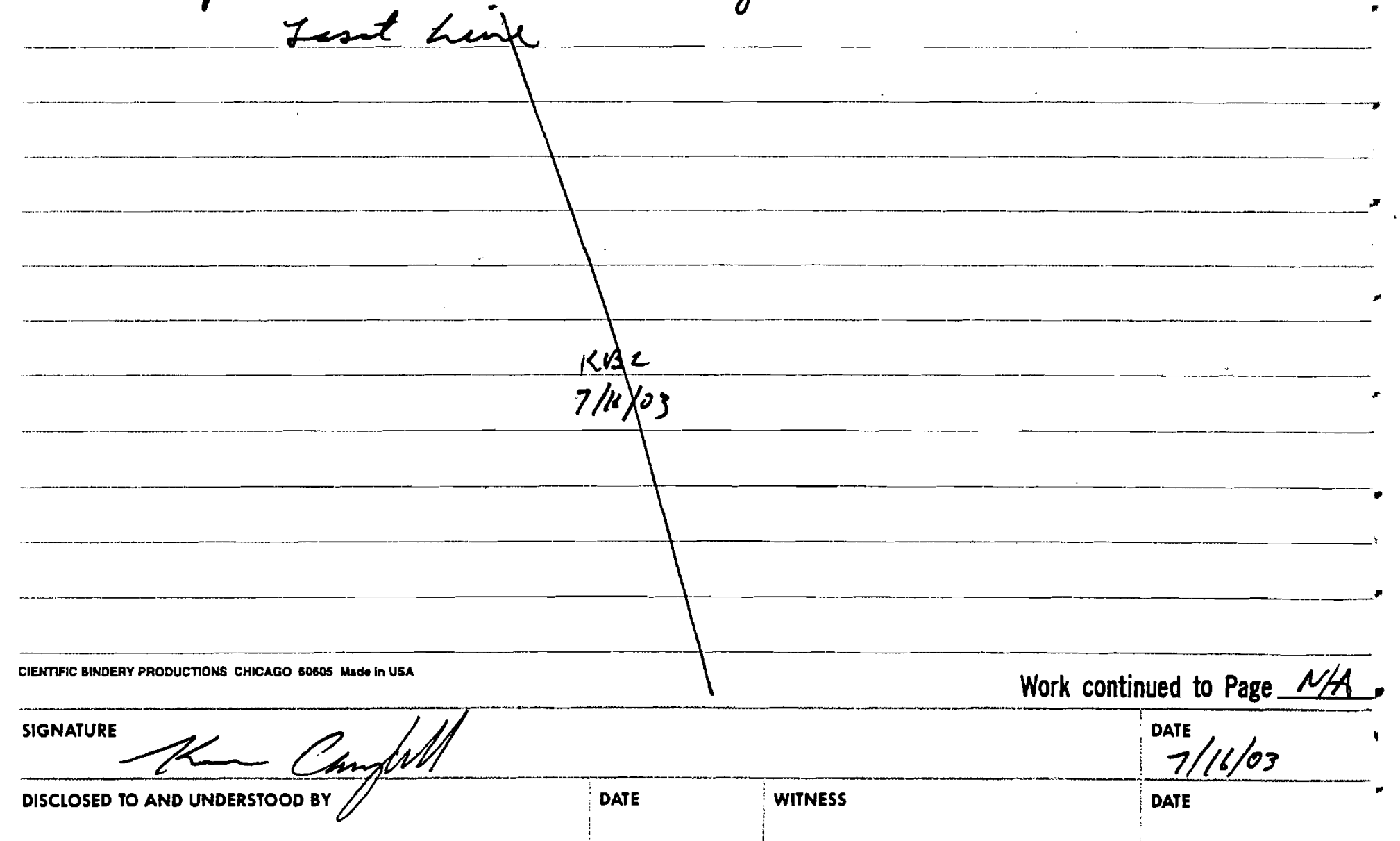




\section{ATTACHMENT D}

\section{PHOTOGRAPHS}


Revision: 0

Date: April 2004

THIS PAGE INTENTIONALLY LEFT BLANK 


\section{PHOTOGRAPH LOG}

\begin{tabular}{|c|c|c|}
\hline $\begin{array}{l}\text { Photo } \\
\text { Number }\end{array}$ & Date & Photograph Description \\
\hline 1 & $06 / 10 / 2003$ & CAU 400 Bomblet Pit, looking east \\
\hline 2 & $12 / 03 / 2003$ & CAU 400 Bomblet Pit, looking east \\
\hline 3 & $06 / 10 / 2003$ & CAU 400 Five-Points Landfill, looking east \\
\hline 4 & $12 / 03 / 2003$ & CAU 400 Five-Points Landfill, looking east \\
\hline 5 & $06 / 10 / 2003$ & $\begin{array}{l}\text { CAU } 404 \text { Roller Coaster Lagoons and Trench, looking east. Lagoon } \\
\text { cover can be seen in the distance. }\end{array}$ \\
\hline 6 & $12 / 03 / 2003$ & $\begin{array}{l}\text { CAU } 404 \text { Roller Coaster Lagoons and Trench, looking east. Lagoon } \\
\text { cover can be seen in the distance. }\end{array}$ \\
\hline 7 & $06 / 10 / 2003$ & CAU 407 Roller Coaster RadSafe Area, looking east \\
\hline 8 & $12 / 03 / 2003$ & CAU 407 Roller Coaster RadSafe Area, looking east \\
\hline 9 & $12 / 03 / 2003$ & $\begin{array}{l}\text { CAU } 407 \text { Roller Coaster RadSafe Area, looking south. Note erosion } \\
\text { on cover margin slope. }\end{array}$ \\
\hline 10 & $12 / 03 / 2003$ & $\begin{array}{l}\text { CAU } 407 \text { Roller Coaster RadSafe Area, looking north. Note erosion } \\
\text { on cover margin slope. }\end{array}$ \\
\hline 11 & $06 / 10 / 2003$ & $\begin{array}{l}\text { CAU } 424 \text { Area } 3 \text { Landfill Complexes Landfill Cell A3-1, looking } \\
\text { northeast. Some small animal burrows are present around the } \\
\text { concrete monument in the foreground. }\end{array}$ \\
\hline 12 & $12 / 03 / 2003$ & $\begin{array}{l}\text { CAU } 424 \text { Area } 3 \text { Landfill Complexes Landfill Cell A3-1, looking } \\
\text { northeast }\end{array}$ \\
\hline 13 & $06 / 10 / 2003$ & $\begin{array}{l}\text { CAU } 424 \text { Area } 3 \text { Landfill Complexes Landfill Cell A3-2, looking } \\
\text { north }\end{array}$ \\
\hline 14 & $12 / 03 / 2003$ & $\begin{array}{l}\text { CAU } 424 \text { Area } 3 \text { Landfill Complexes Landfill Cell A3-2, looking } \\
\text { north }\end{array}$ \\
\hline 15 & $06 / 10 / 2003$ & CAU 424 Area 3 Landfill Complexes Landfill Cell A3-3, looking east \\
\hline 16 & $12 / 03 / 2003$ & $\begin{array}{l}\text { CAU } 424 \text { Area } 3 \text { Landfill Complexes Landfill Cell A3-3, looking } \\
\text { north }\end{array}$ \\
\hline 17 & $06 / 10 / 2003$ & $\begin{array}{l}\text { CAU } 424 \text { Area } 3 \text { Landfill Complexes Landfill Cell A3-3 (monument } \\
\text { marked by orange cone), looking west. An excavation to remove } \\
\text { hydrocarbon-impacted soil associated with CAU } 410 \text { is located } \\
\text { adjacent to the north edge of the CAU } 424 \text { at-grade monument. }\end{array}$ \\
\hline 18 & $12 / 03 / 2003$ & $\begin{array}{l}\text { CAU } 424 \text { Area } 3 \text { Landfill Complexes Landfill Cell A3-3 (monument } \\
\text { marked by orange cone), looking west. The excavation associated } \\
\text { with CAU } 410 \text { has been filled. The adjacent landfill monument was } \\
\text { not compromised by the excavation activities. }\end{array}$ \\
\hline 19 & $06 / 10 / 2003$ & $\begin{array}{l}\text { CAU } 424 \text { Area } 3 \text { Landfill Complexes Landfill Cell A3-3, looking } \\
\text { north }\end{array}$ \\
\hline 20 & $12 / 03 / 2003$ & $\begin{array}{l}\text { CAU } 424 \text { Area } 3 \text { Landfill Complexes Landfill Cell A3-3, looking } \\
\text { north }\end{array}$ \\
\hline 21 & $06 / 10 / 2003$ & $\begin{array}{l}\text { CAU } 424 \text { Area } 3 \text { Landfill Complexes Landfill Cell A3-4, looking } \\
\text { north }\end{array}$ \\
\hline 22 & $12 / 03 / 2003$ & $\begin{array}{l}\text { CAU } 424 \text { Area } 3 \text { Landfill Complexes Landfill Cell A3-4, looking } \\
\text { north }\end{array}$ \\
\hline 23 & $06 / 10 / 2003$ & $\begin{array}{l}\text { CAU } 424 \text { Area } 3 \text { Landfill Complexes Landfill Cell A3-5, looking } \\
\text { southeast }\end{array}$ \\
\hline
\end{tabular}




\begin{tabular}{|c|c|c|}
\hline $\begin{array}{c}\text { Photo } \\
\text { Number }\end{array}$ & Date & Photograph Description \\
\hline 24 & $12 / 03 / 2003$ & $\begin{array}{l}\text { CAU } 424 \text { Area } 3 \text { Landfill Complexes Landfill Cell A3-4, looking } \\
\text { northeast }\end{array}$ \\
\hline 25 & $06 / 10 / 2003$ & $\begin{array}{l}\text { CAU } 424 \text { Area } 3 \text { Landfill Complexes Landfill Cell A3-6, looking } \\
\text { northwest }\end{array}$ \\
\hline 26 & $12 / 03 / 2003$ & $\begin{array}{l}\text { CAU } 424 \text { Area } 3 \text { Landfill Complexes Landfill Cell A3-6, looking } \\
\text { northwest }\end{array}$ \\
\hline 27 & $06 / 10 / 2003$ & $\begin{array}{l}\text { CAU } 424 \text { Area } 3 \text { Landfill Complexes Landfill Cell A3-8, looking } \\
\text { west }\end{array}$ \\
\hline 28 & $12 / 03 / 2003$ & $\begin{array}{l}\text { CAU } 424 \text { Area } 3 \text { Landfill Complexes Landfill Cell A3-8, looking } \\
\text { west }\end{array}$ \\
\hline 29 & $07 / 09 / 2003$ & $\begin{array}{l}\text { CAU } 424 \text { Area } 3 \text { Landfill Complexes Landfill Cell A3-3, July } 2003 \\
\text { repairs. At-grade monuments are being stamped with land-use } \\
\text { restriction coordinates. }\end{array}$ \\
\hline 30 & $07 / 09 / 2003$ & $\begin{array}{l}\text { CAU } 424 \text { Area } 3 \text { Landfill Complexes Landfill Cell A3-4, July } 2003 \\
\text { repairs. Above-grade monument is being stamped with land-use } \\
\text { restriction coordinates. }\end{array}$ \\
\hline 31 & $06 / 10 / 2003$ & $\begin{array}{l}\text { CAU } 426 \text { Cactus Spring Waste Trenches, looking northwest. The } \\
\text { south fence line has been damaged by horses. }\end{array}$ \\
\hline 32 & $12 / 03 / 2003$ & $\begin{array}{l}\text { CAU } 426 \text { Cactus Spring Waste Trenches, looking northwest. The } \\
\text { south fence line has been repaired. }\end{array}$ \\
\hline 33 & $06 / 10 / 2003$ & CAU 427 Area 3 Septic Waste Systems 2, 6, looking north \\
\hline 34 & $12 / 03 / 2003$ & $\begin{array}{l}\text { CAU } 427 \text { Area } 3 \text { Septic Waste Systems } 2,6 \text {, looking north. } \\
\text { Monuments are in foreground shadow of the photograph. }\end{array}$ \\
\hline 35 & $06 / 10 / 2003$ & CAU 427 Area 3 Septic Waste Systems 2, 6, looking west \\
\hline 36 & $12 / 03 / 2003$ & CAU 427 Area 3 Septic Waste Systems 2, 6, looking west \\
\hline 37 & $06 / 10 / 2003$ & CAU 427 Area 3 Septic Waste Systems 2, 6, looking east \\
\hline 38 & $12 / 03 / 2003$ & CAU 427 Area 3 Septic Waste Systems 2, 6, looking east \\
\hline 39 & $12 / 03 / 2003$ & $\begin{array}{l}\text { CAU } 427 \text { Area } 3 \text { Septic Waste Systems } 2,6 \text {, looking west. A new } \\
\text { use restriction sign was installed on the north side of Bldg 0307T to } \\
\text { clarify the location of buried waste in this area. }\end{array}$ \\
\hline 40 & $07 / 09 / 03$ & $\begin{array}{l}\text { CAU } 427 \text { Area } 3 \text { Septic Waste Systems 2, 6, looking southeast. } \\
\text { Surveyors collect measurement data to support future site inspections } \\
\text { and complete minor maintenance on the subsurface monuments. }\end{array}$ \\
\hline 41 & $06 / 10 / 2003$ & CAU 453 Area 9 UXO Landfill, looking west \\
\hline 42 & $12 / 03 / 2003$ & CAU 453 Area 9 UXO Landfill, looking west \\
\hline 43 & $12 / 03 / 2003$ & $\begin{array}{l}\text { CAU } 487 \text { Thunderwell Site, looking west. Land-use restriction } \\
\text { location (Anomaly A-17). The sign and post have been destroyed by } \\
\text { horses. }\end{array}$ \\
\hline 44 & $12 / 03 / 2003$ & $\begin{array}{l}\text { CAU } 487 \text { Thunderwell Site, looking south. Land-use restriction } \\
\text { location (Anomaly A-8). The sign and post have been destroyed by } \\
\text { horses. }\end{array}$ \\
\hline
\end{tabular}




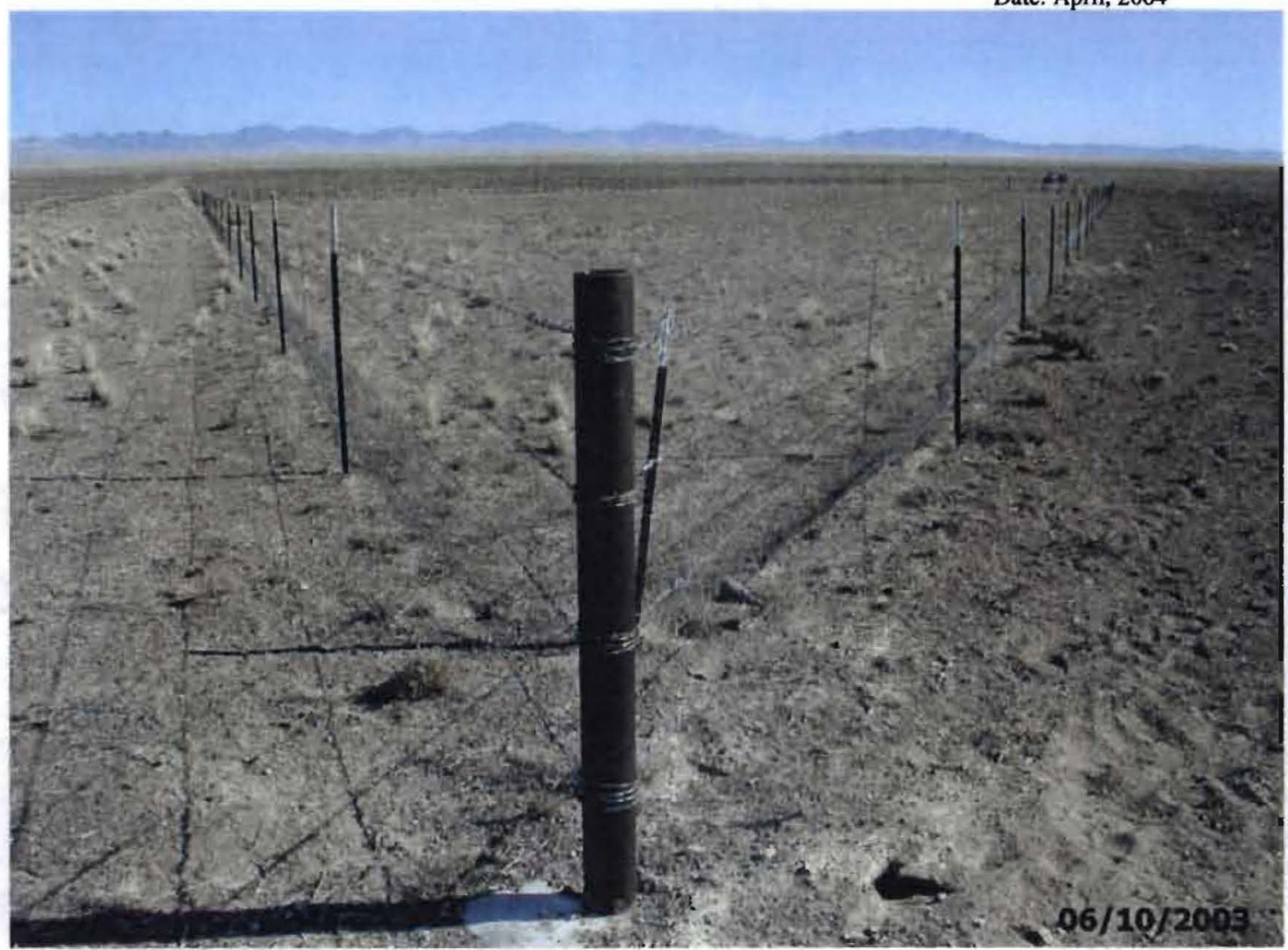

1. CAU 400 Bomblet Pit, looking east

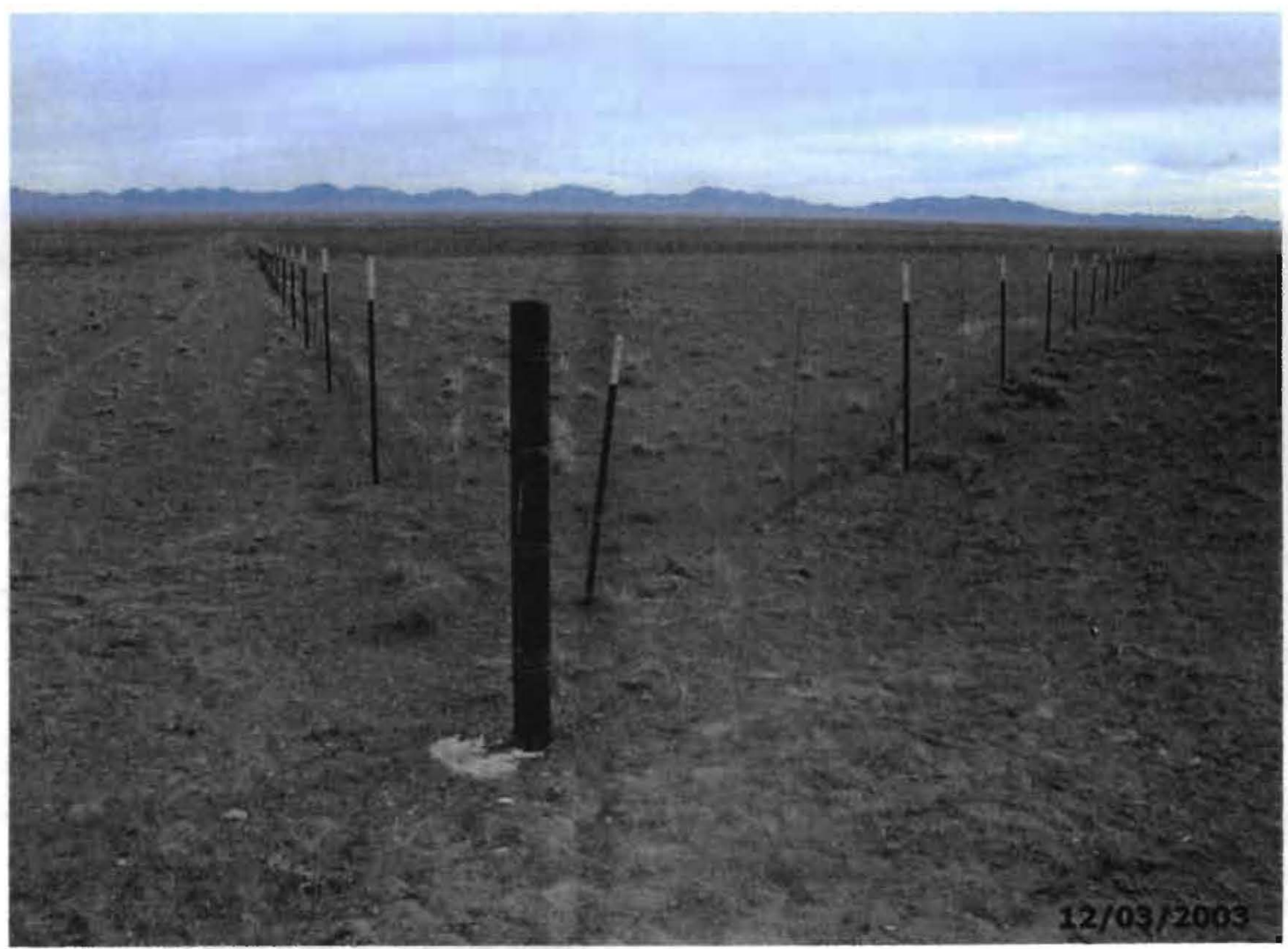

2. CAU 400 Bomblet Pit, looking east 
Tonopah Test Range

2003 Post-Closure Inspection Report

Revision: 0

Date: April, 2004

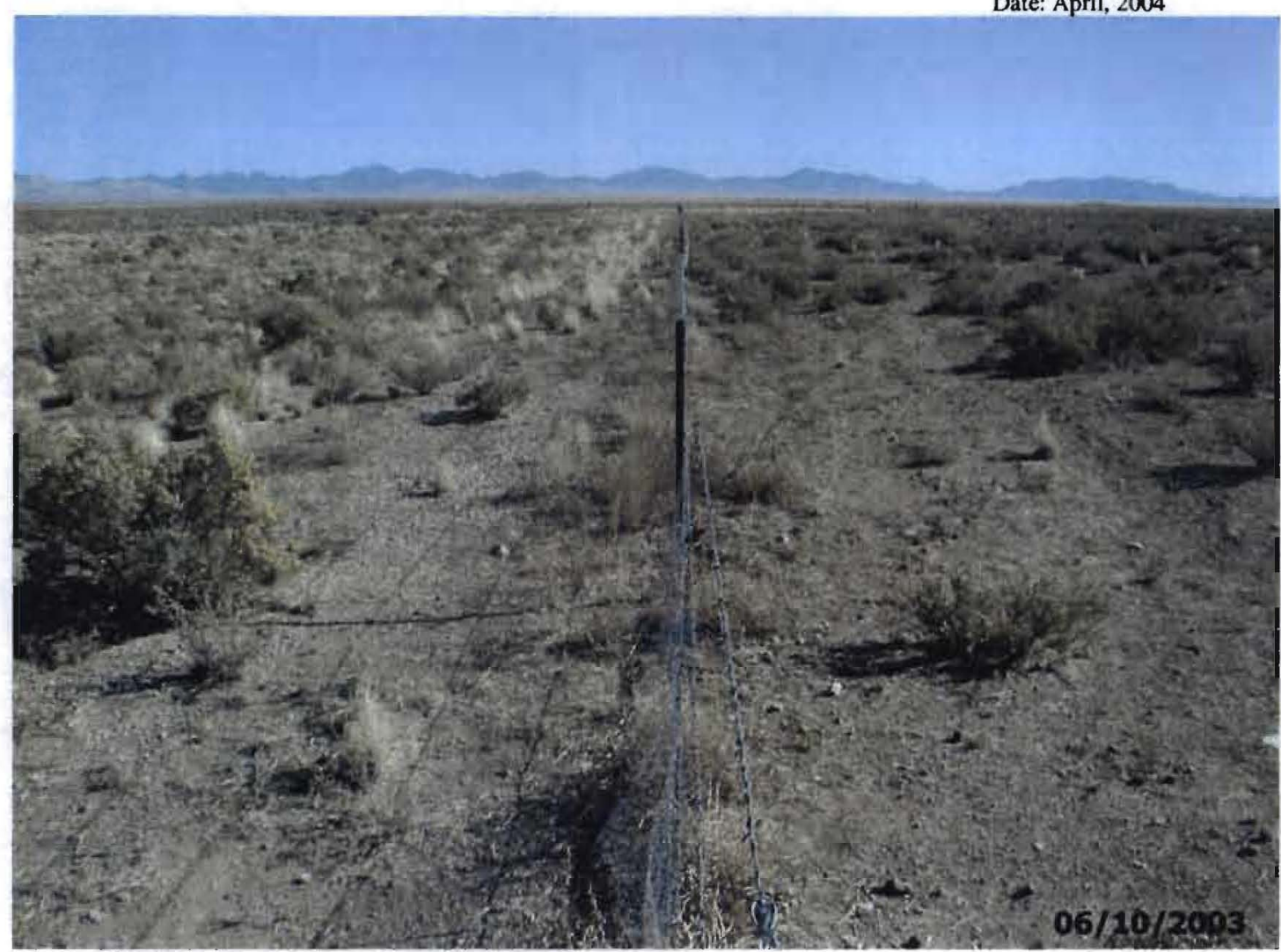

3. CAU 400 Five-Points Landfill, looking east

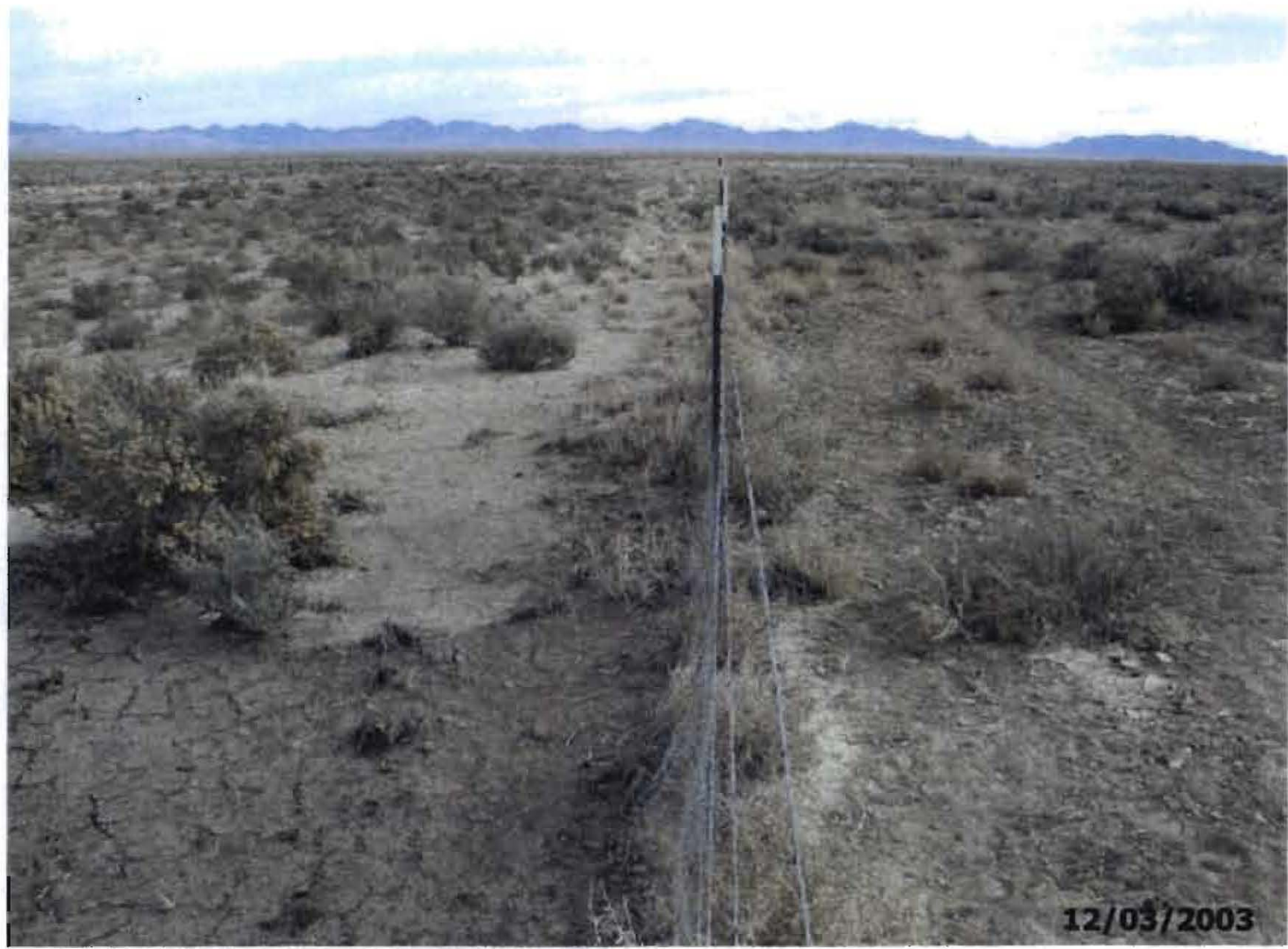

4. CAU 400 Five-Points Landfill, looking east

D-4 
Revision: 0

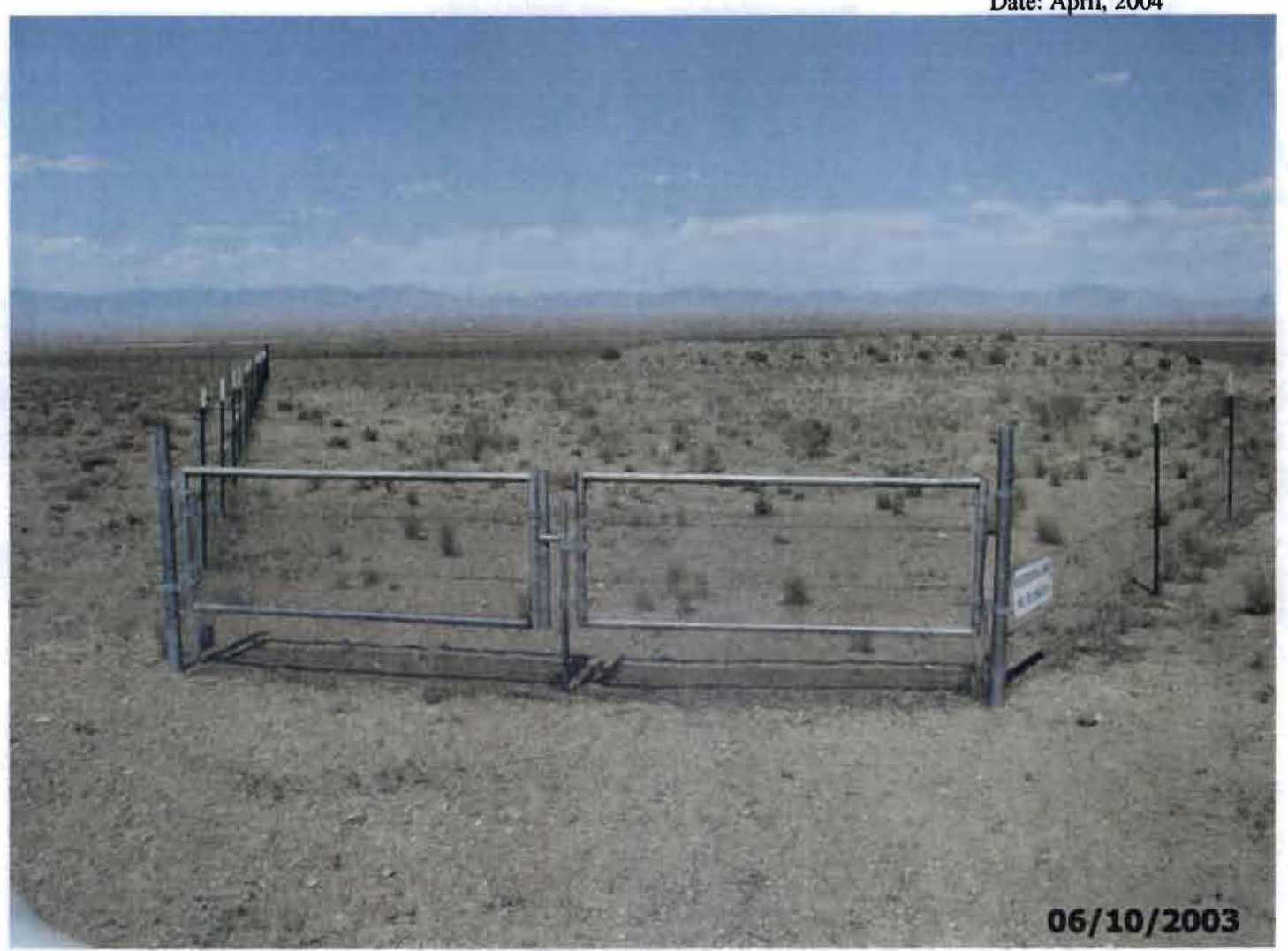

\section{CAU 404 Roller Coaster Lagoons and Trench, looking east}

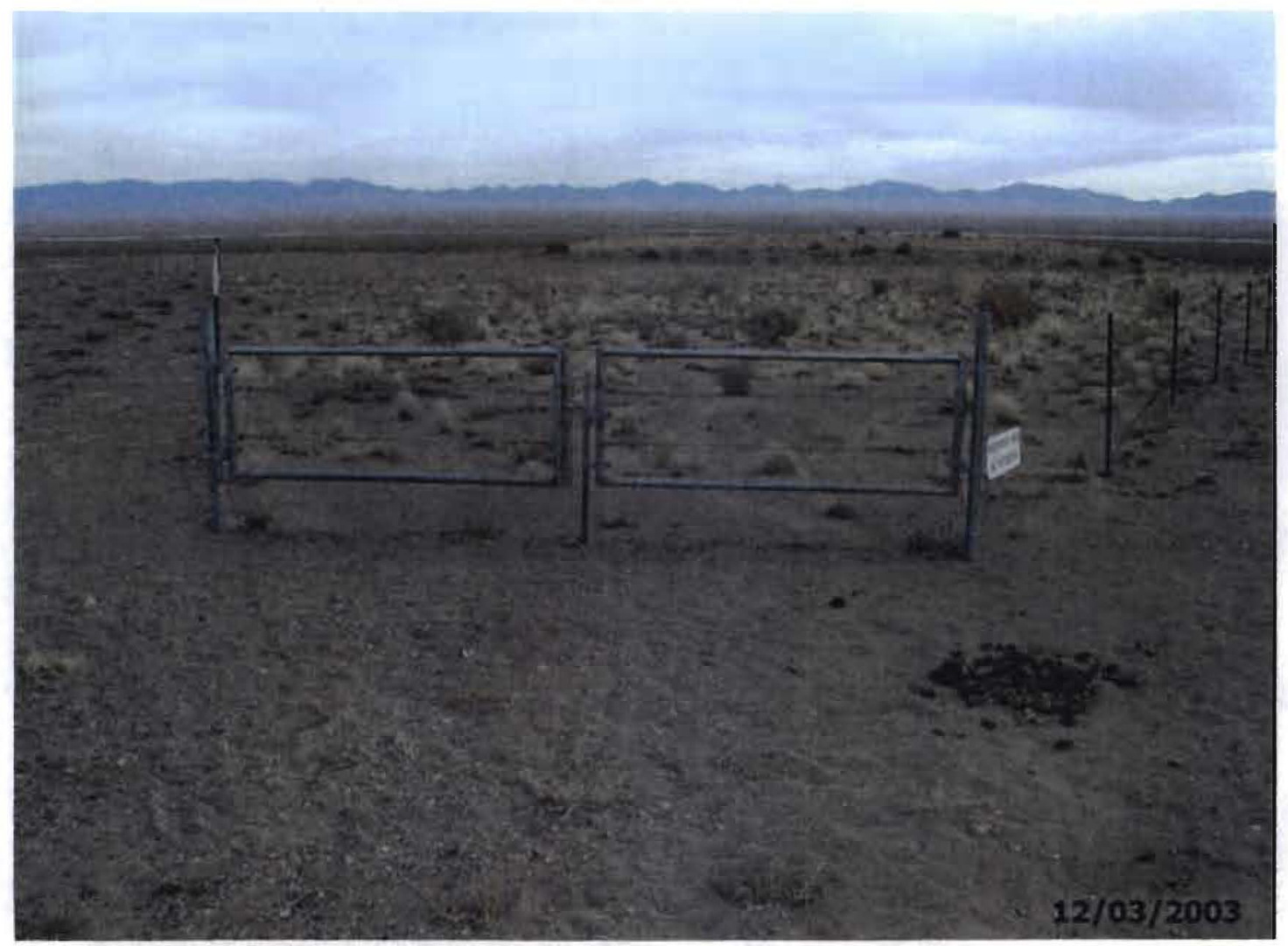

6. CAU 404 Roller Coaster Lagoons and Trench, looking east

D-5 
Date: April, 2004

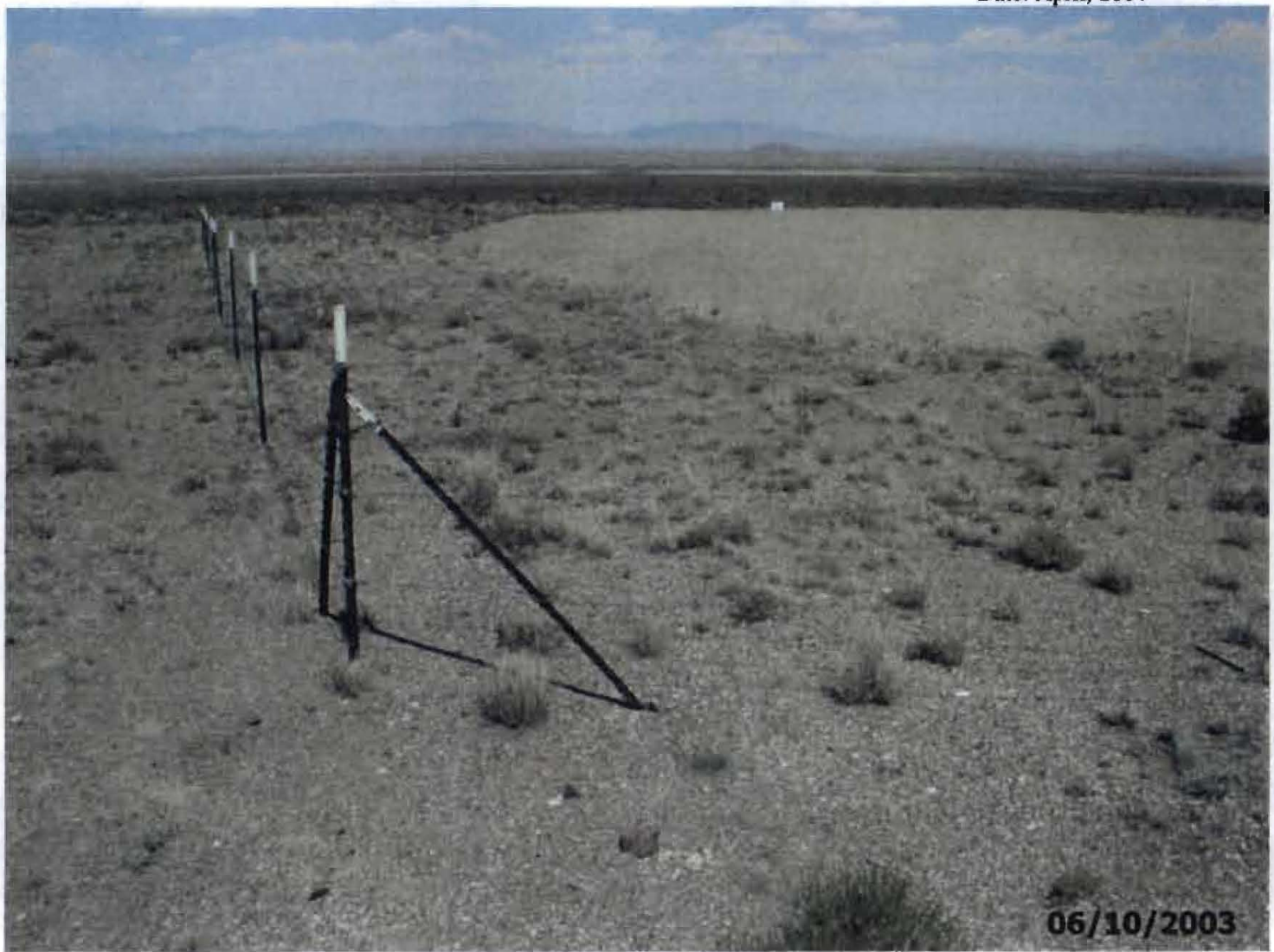

7. CAU 407 Roller Coaster RadSafe Area, looking, east

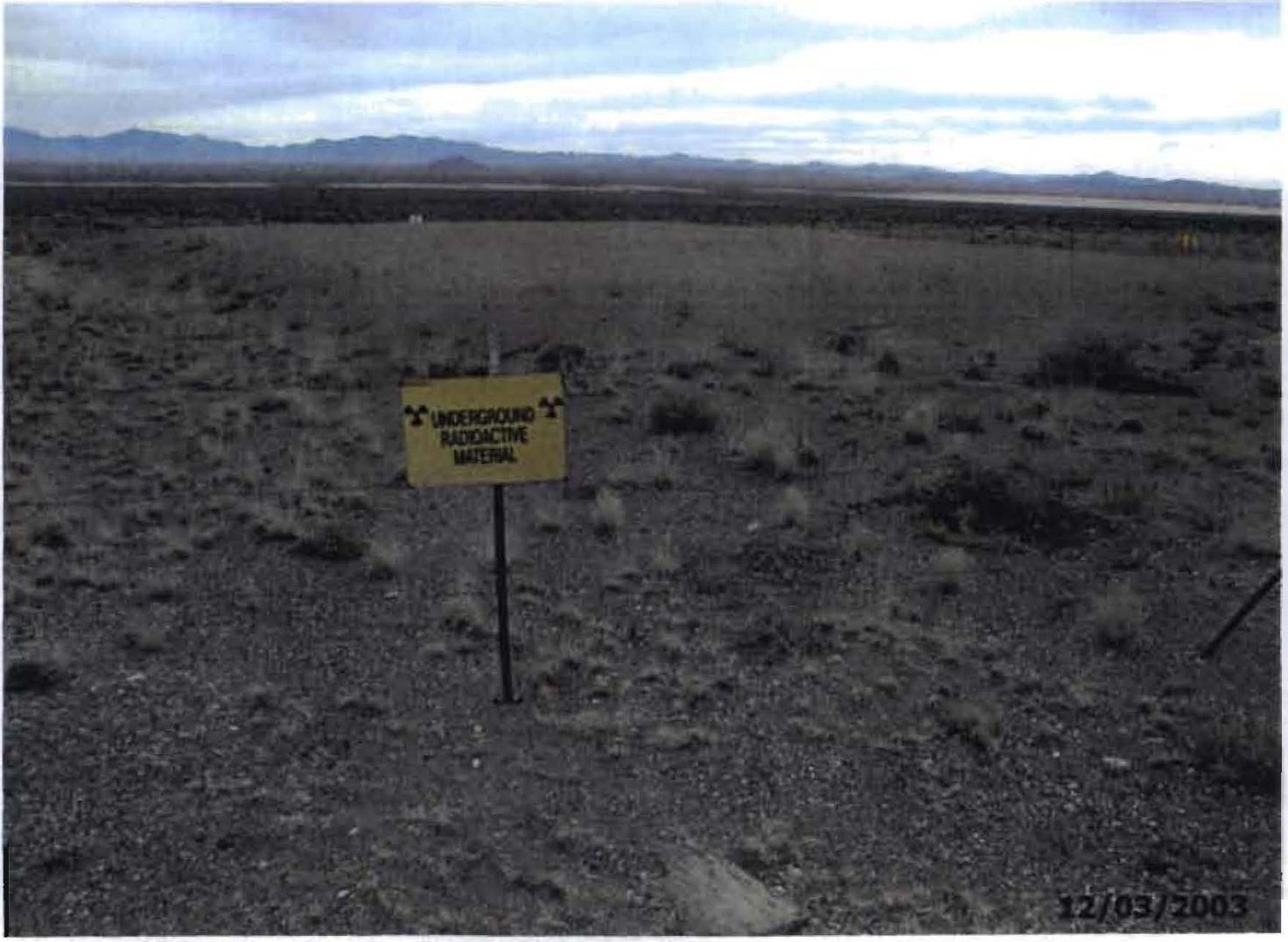

8. CAU 407 Roller Coaster RadSafe Area, looking east

D-6 


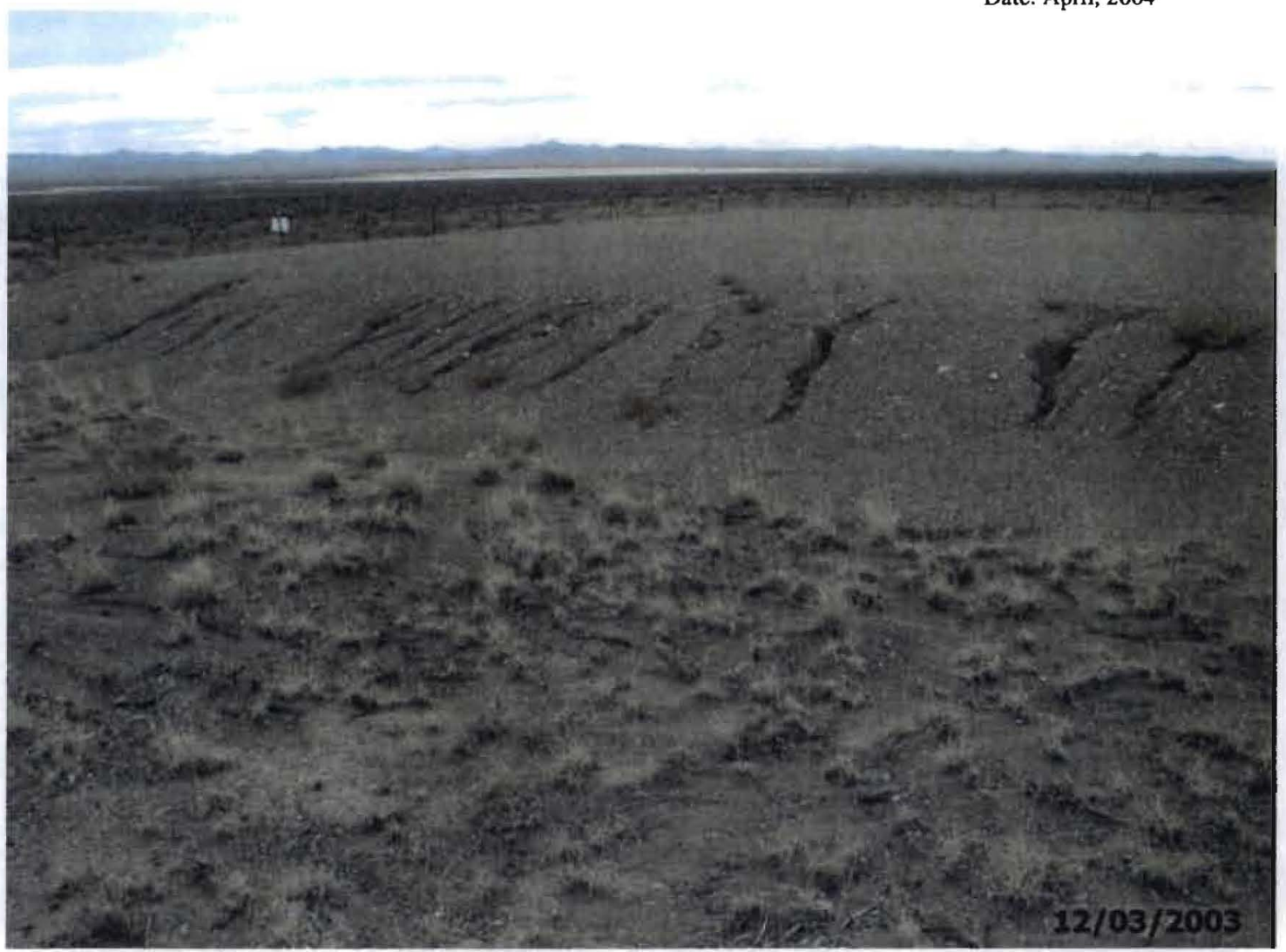

9. CAU 407 Roller Coaster RadSafe Area, looking south showing erosion on cover

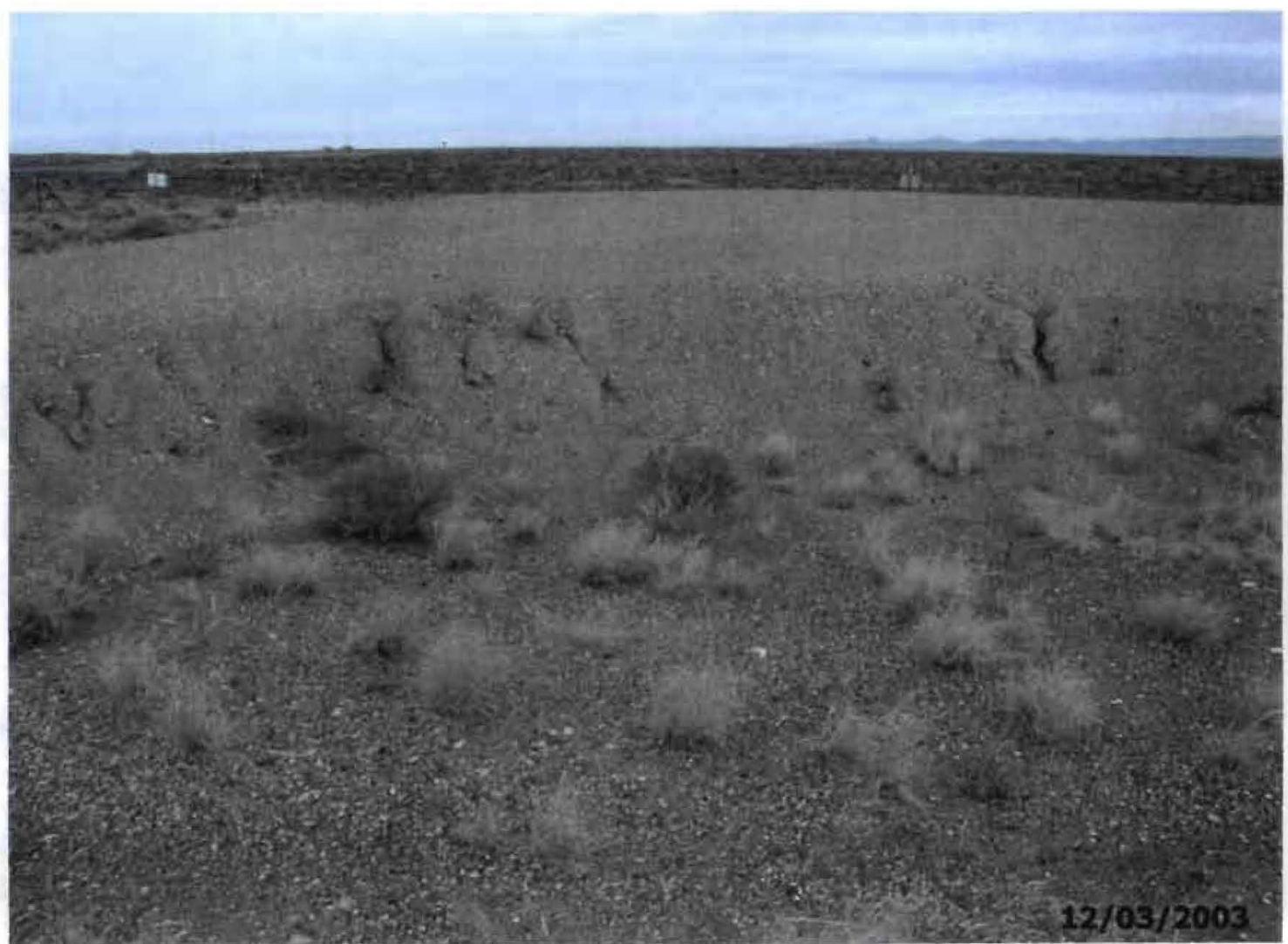

10. CAU 407 Roller Coaster RadSafe Area, looking north showing erosion on cover

D-7 


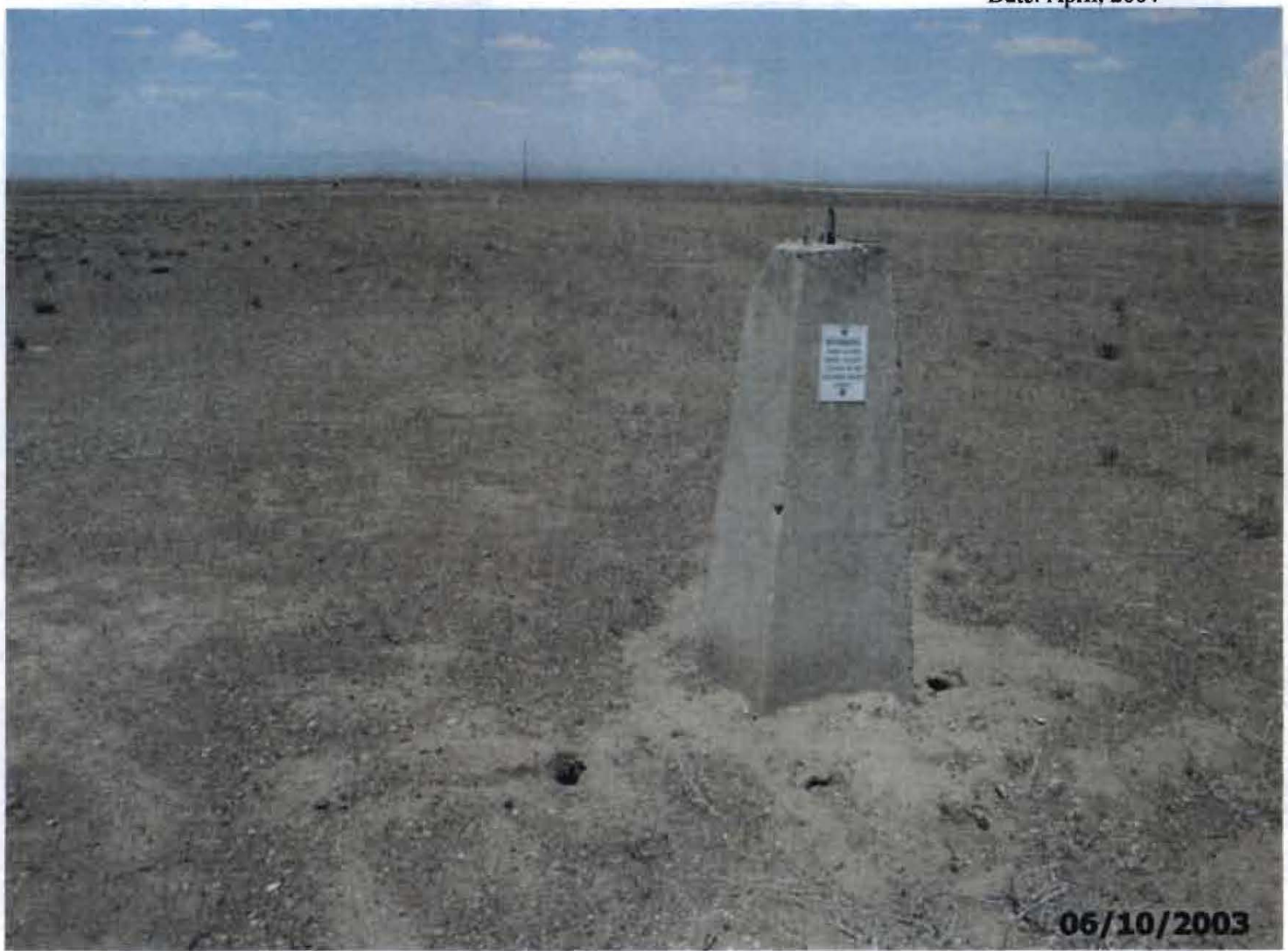

11. CAU 424 Area 3 Landfill Complexes Landfill Cell A3-1, looking northeast

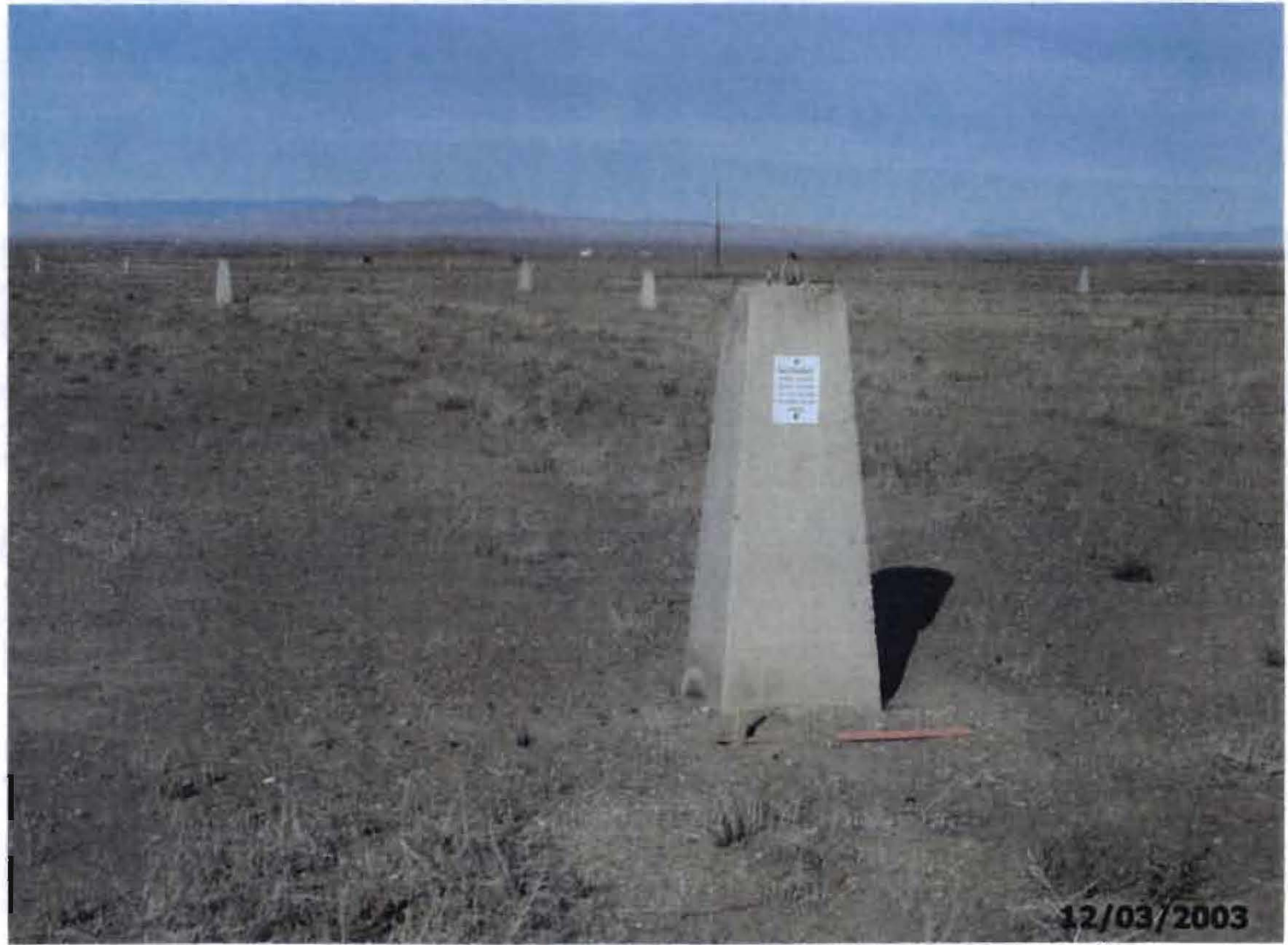

12. CAU 424 Area 3 Landfill Complexes Landfill Cell A3-1, looking northeast

D-8 


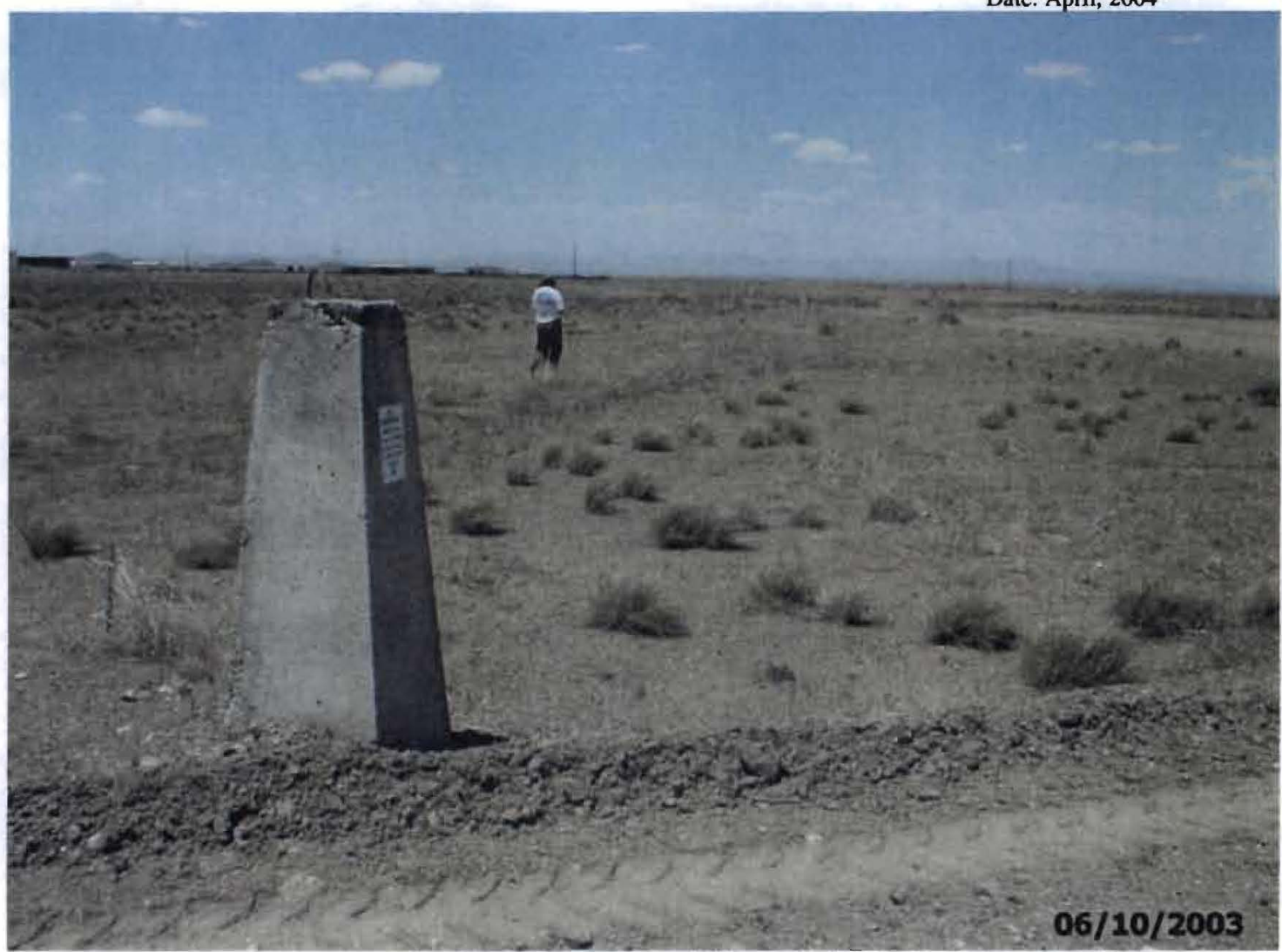

13. CAU 424 Area 3 Landfill Complexes Landfill Cell A3-2, looking north

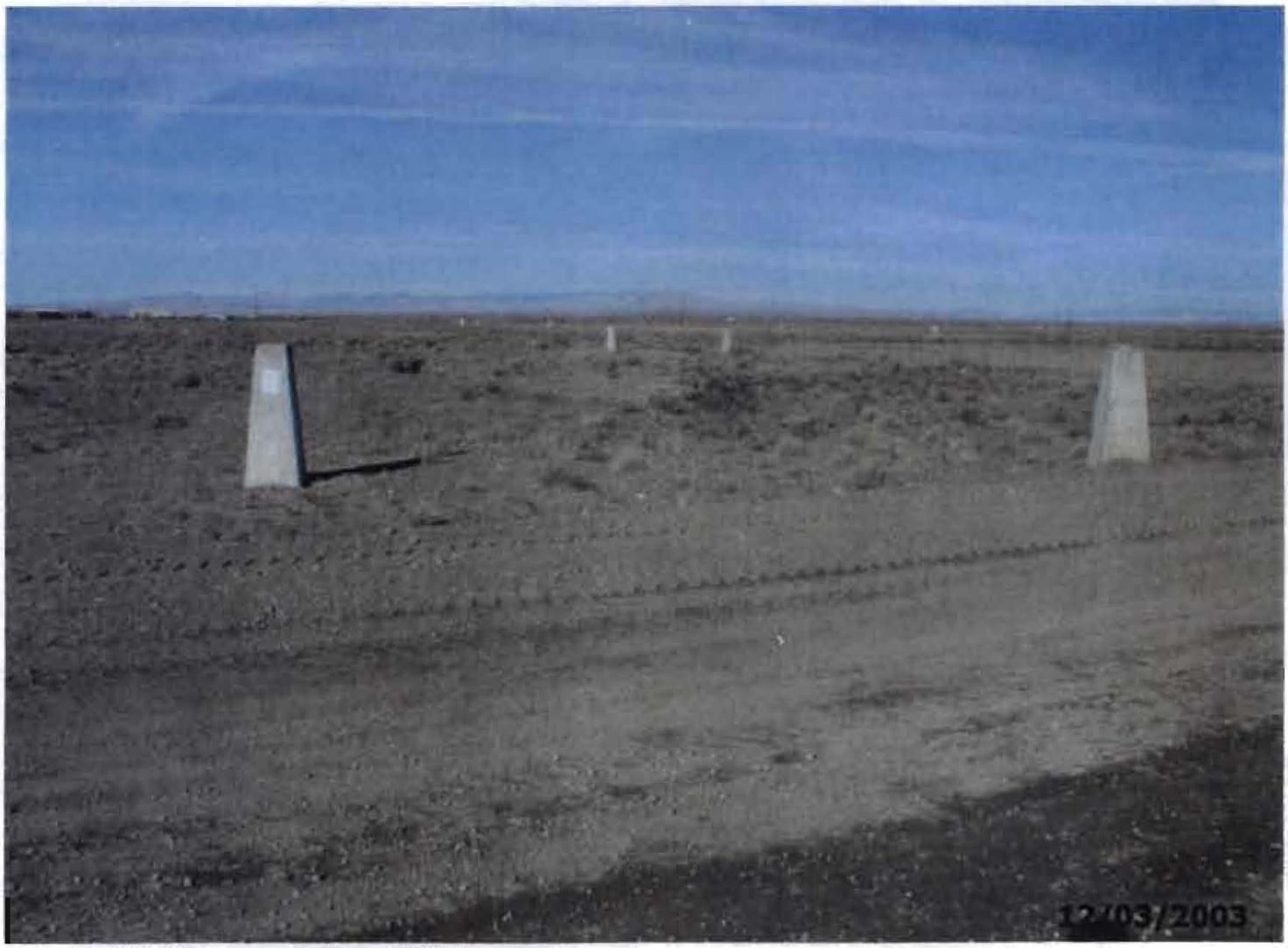

14. CAU 424 Area 3 Landfill Complexes Landfill Cell A3-2, looking north

D-9 


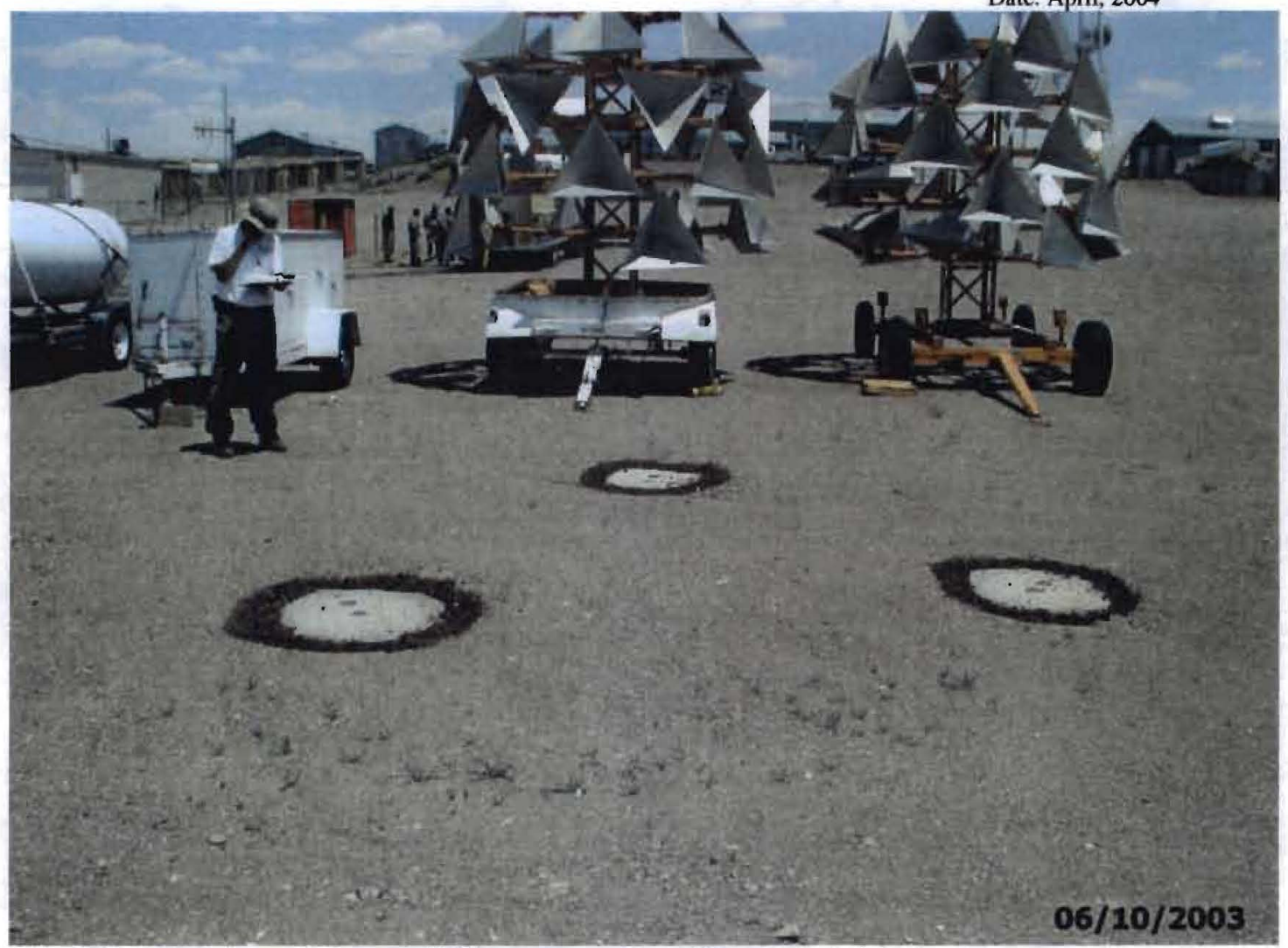

15. CAU 424 Area 3 Landfill Complexes Landfill Cell A3-3, looking east

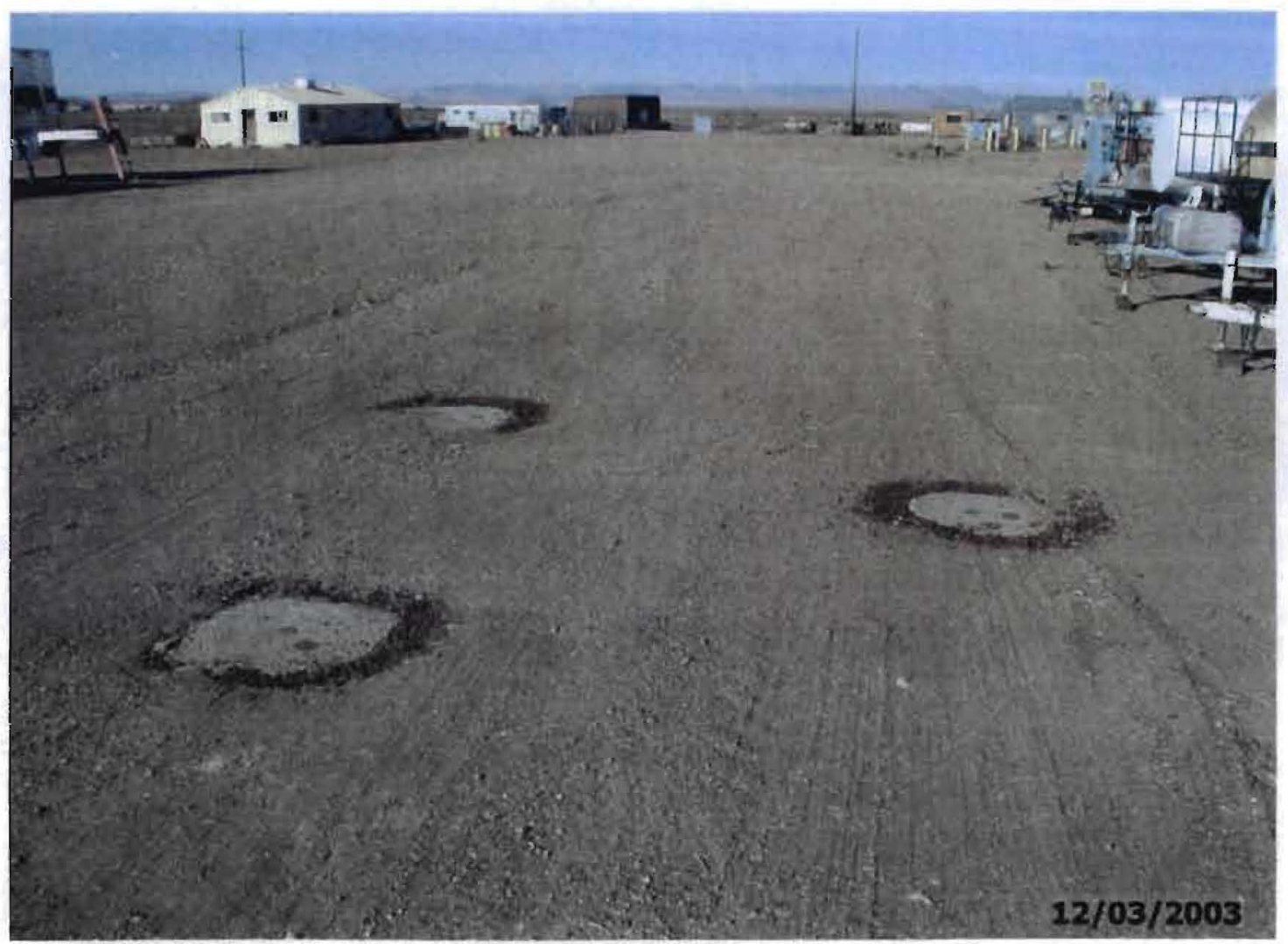

16. CAU 424 Area 3 Landfill Complexes Landfill Cell A3-3, looking north

D-10 
Tonopah Test Range

2003 Post-Closure Inspection Report

Revision: 0

Date: April, 2004

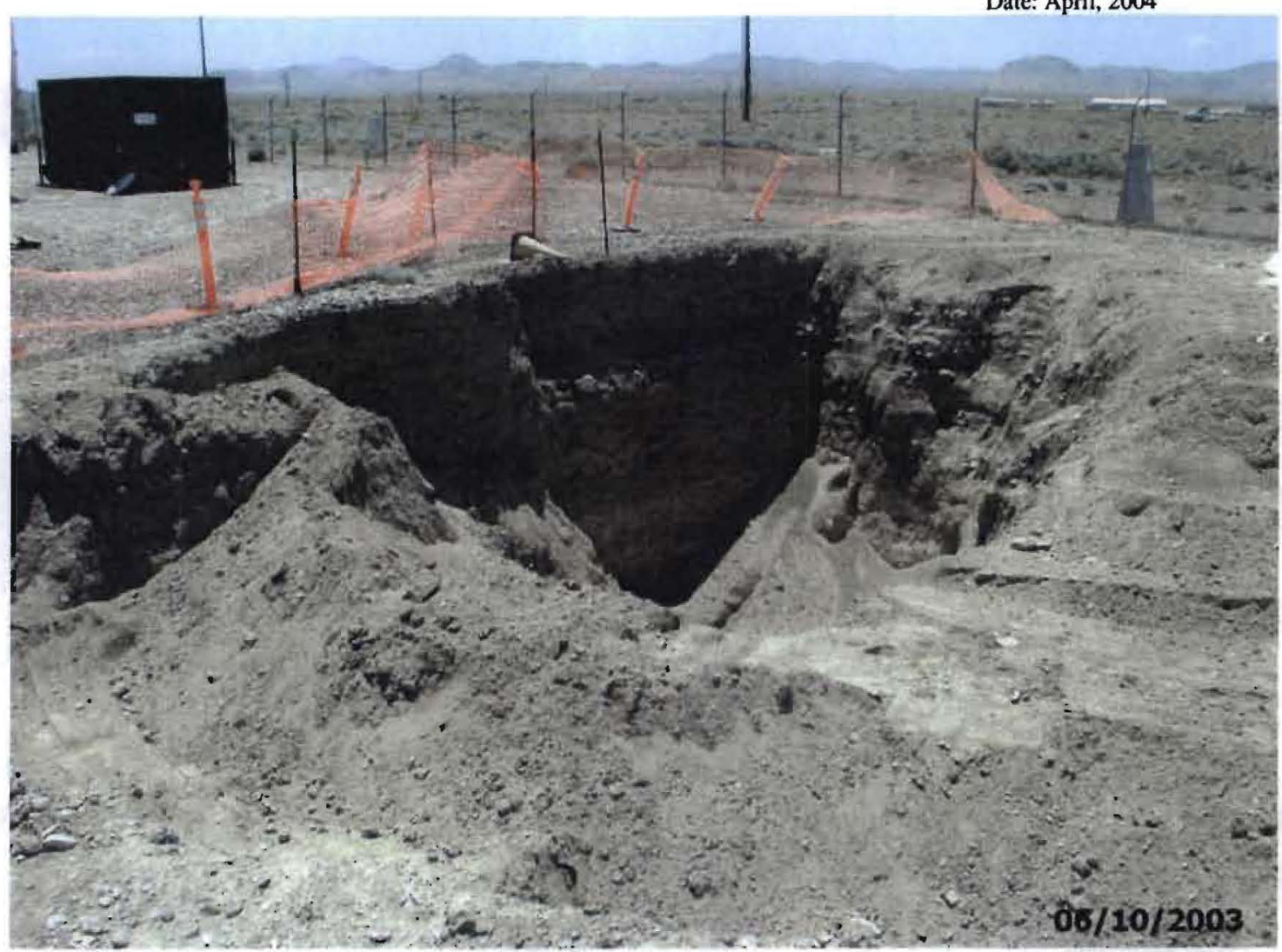

17. CAU 424 Area 3 Landfill Complexes Landfill Cell A3-3 (monument marked by orange cone), looking west (CAU 410 excavation in foreground)

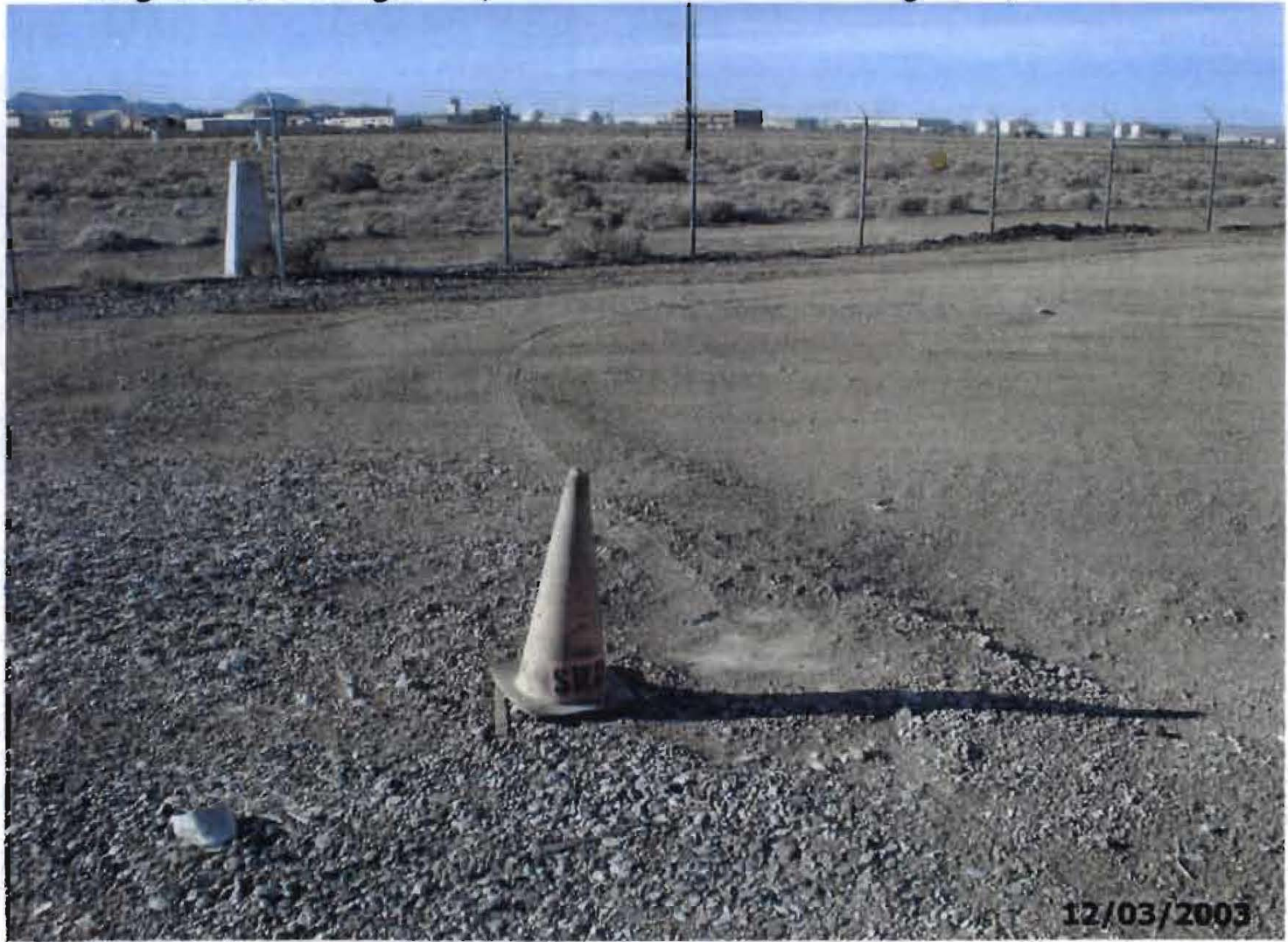

18. CAU 424 Area 3 Landfill Complexes Landfill Cell A3-3 (monument marked by orange cone), looking west (CAU 410 excavation repaired) 


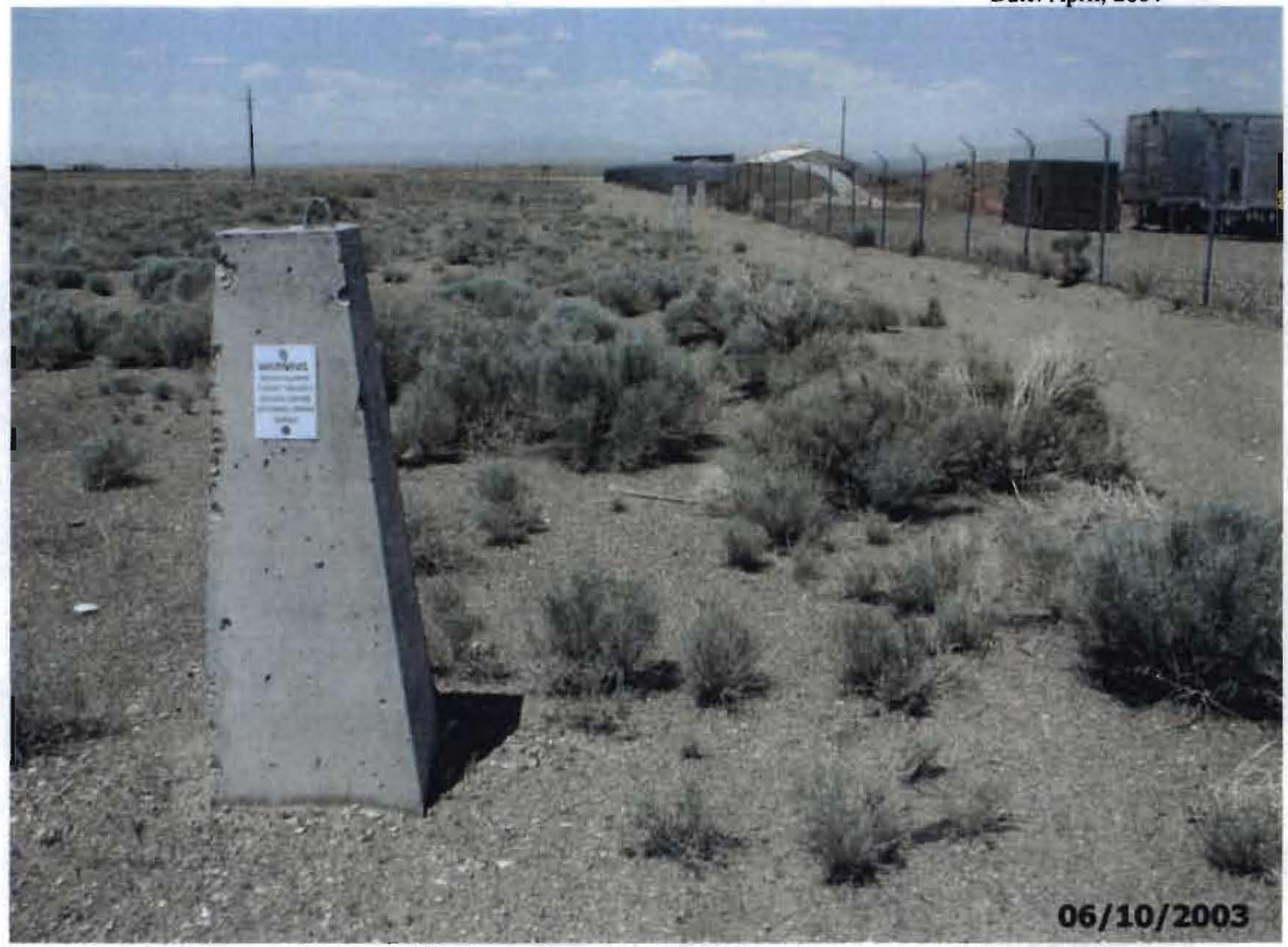

19. CAU 424 Area 3 Landfill Complexes Landfill Cell A3-3, looking north

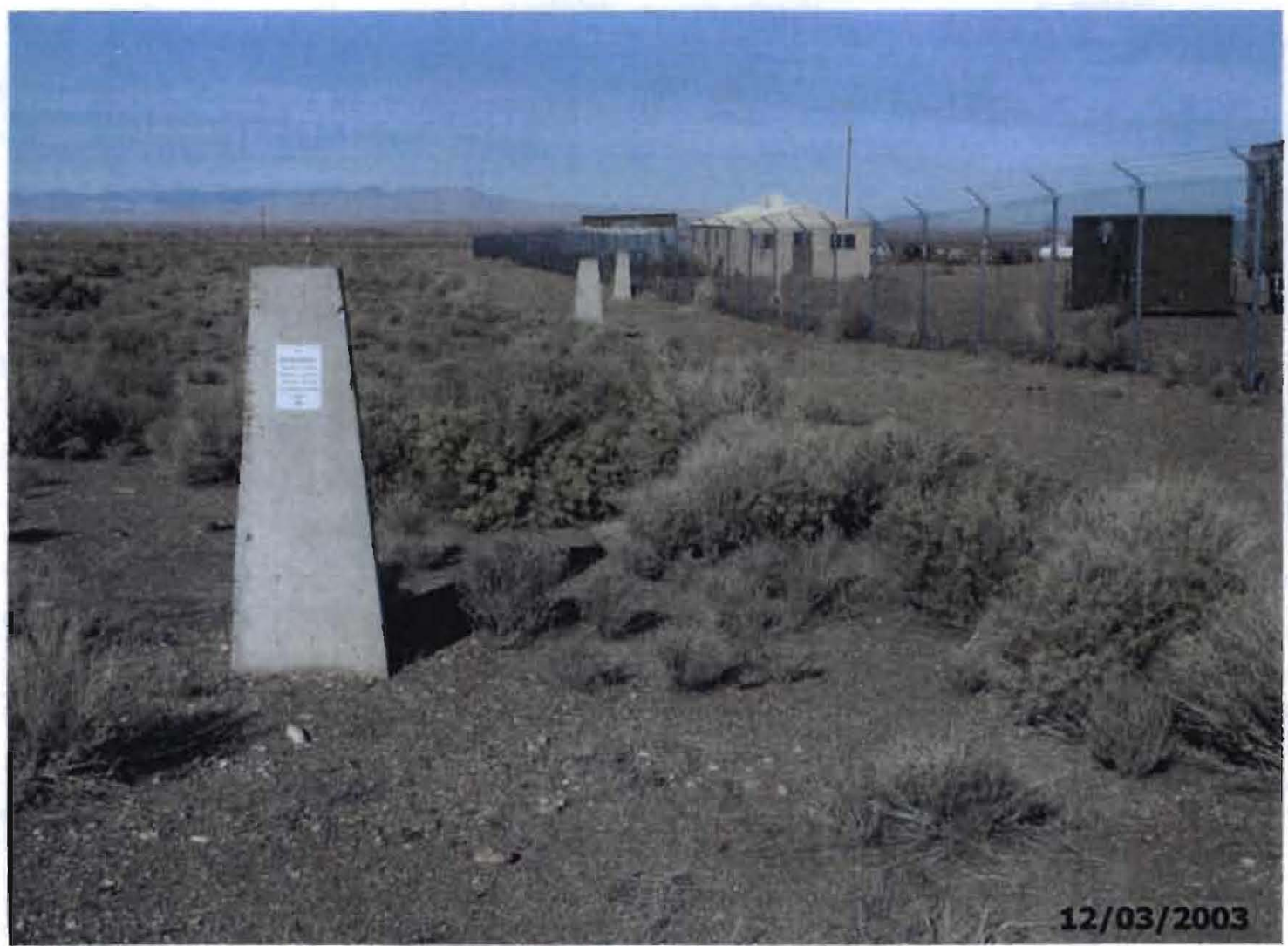

20. CAU 424 Area 3 Landfill Complexes Landfill Cell A3-3, looking north

D-12 


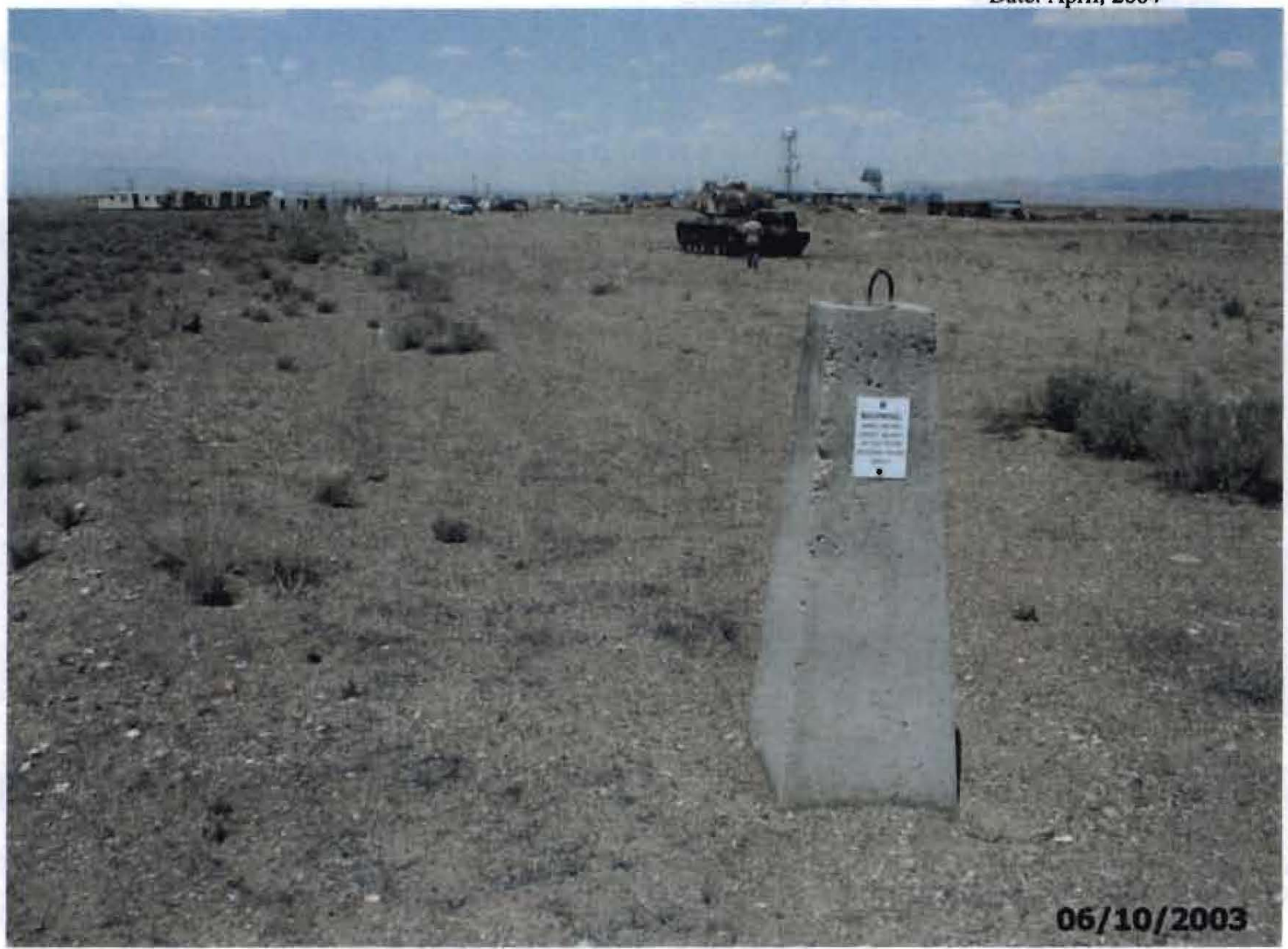

21. CAU 424 Area 3 Landfill Complexes Landfill Cell A3-4, looking north

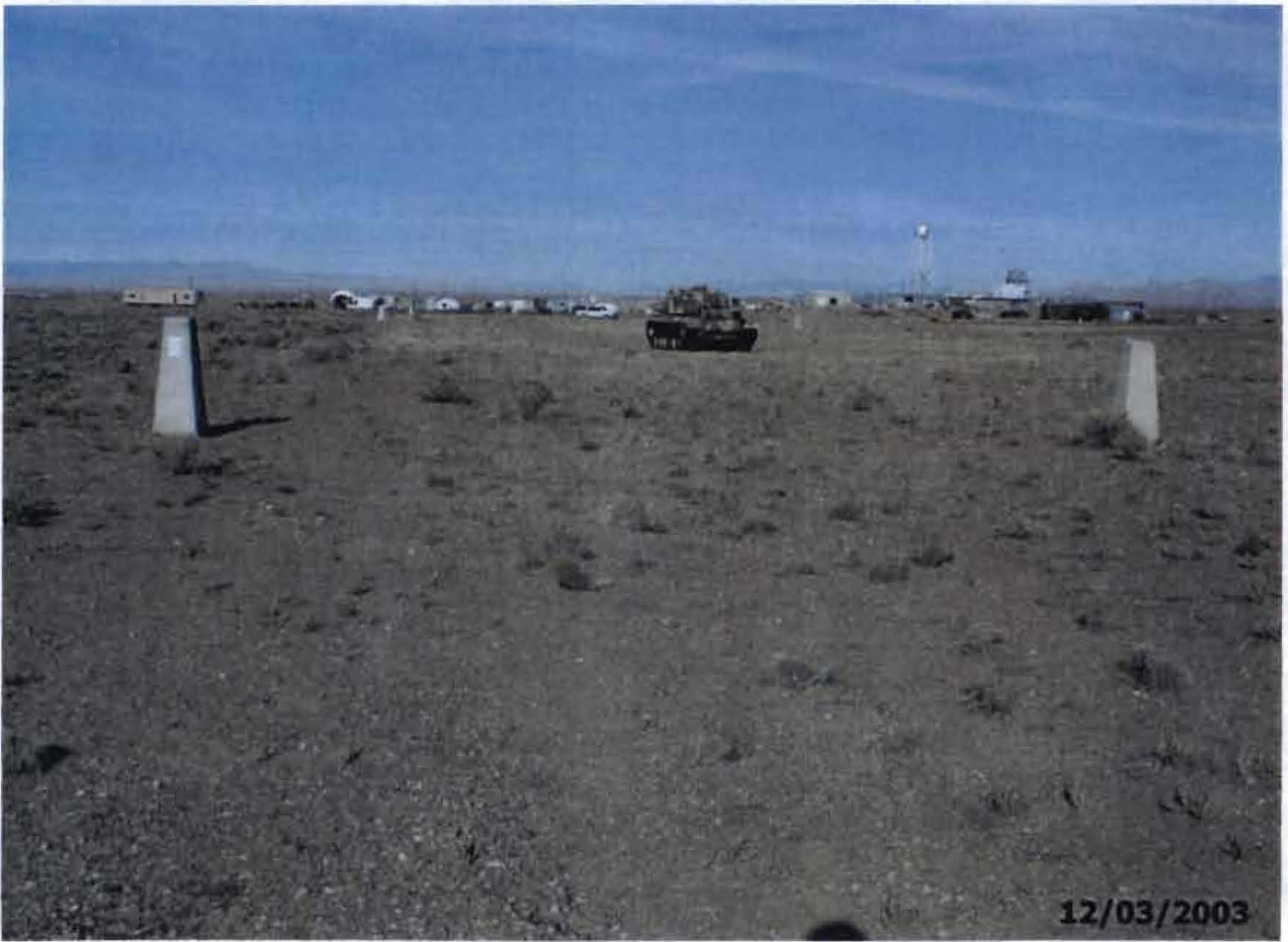

22. CAU 424 Area 3 Landfill Complexes Landfill Cell A3-4, looking north

D-13 
Date: April, 2004

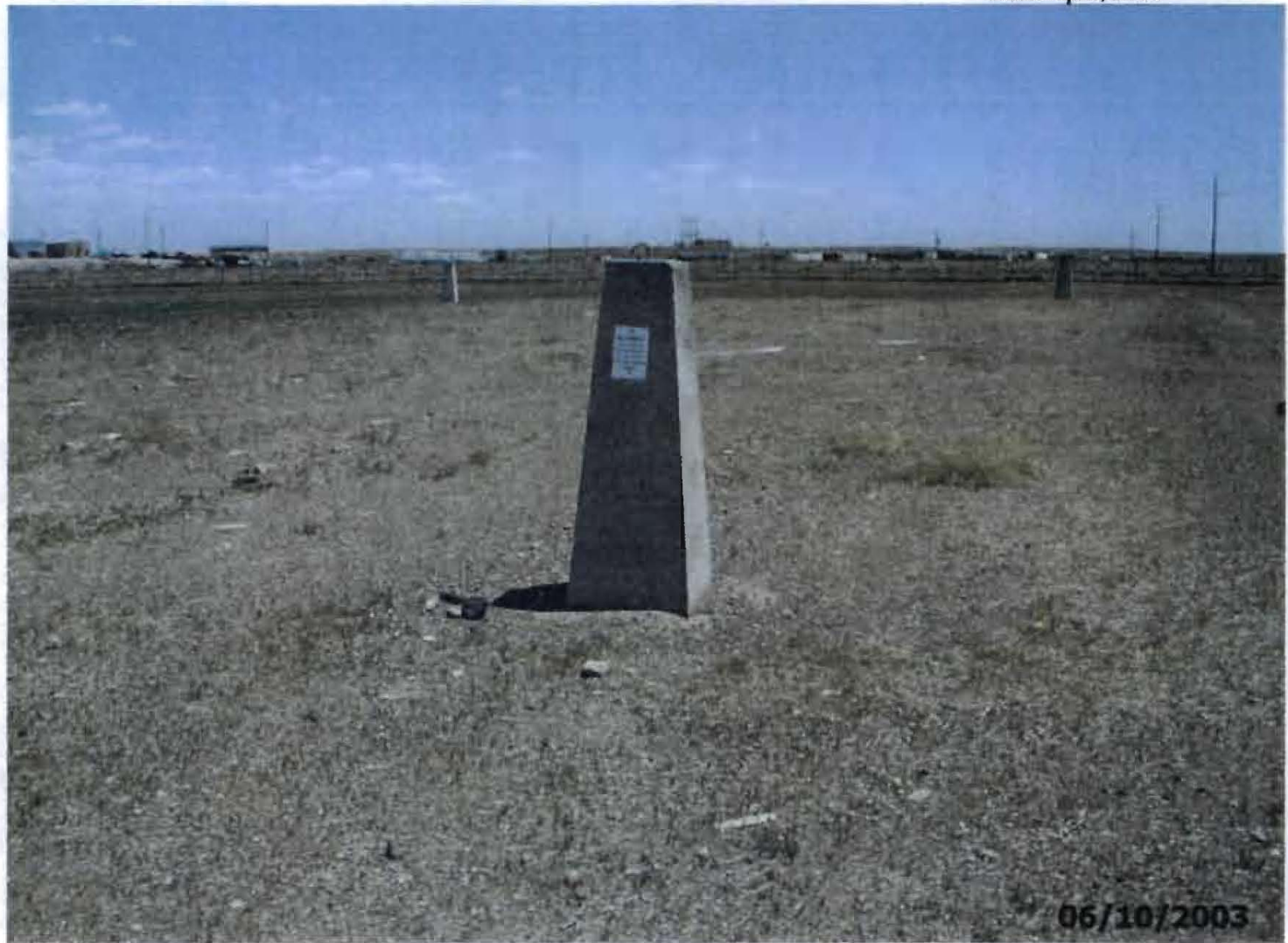

23. CAU 424 Area 3 Landfill Complexes Landfill Cell A3-5, looking southeast

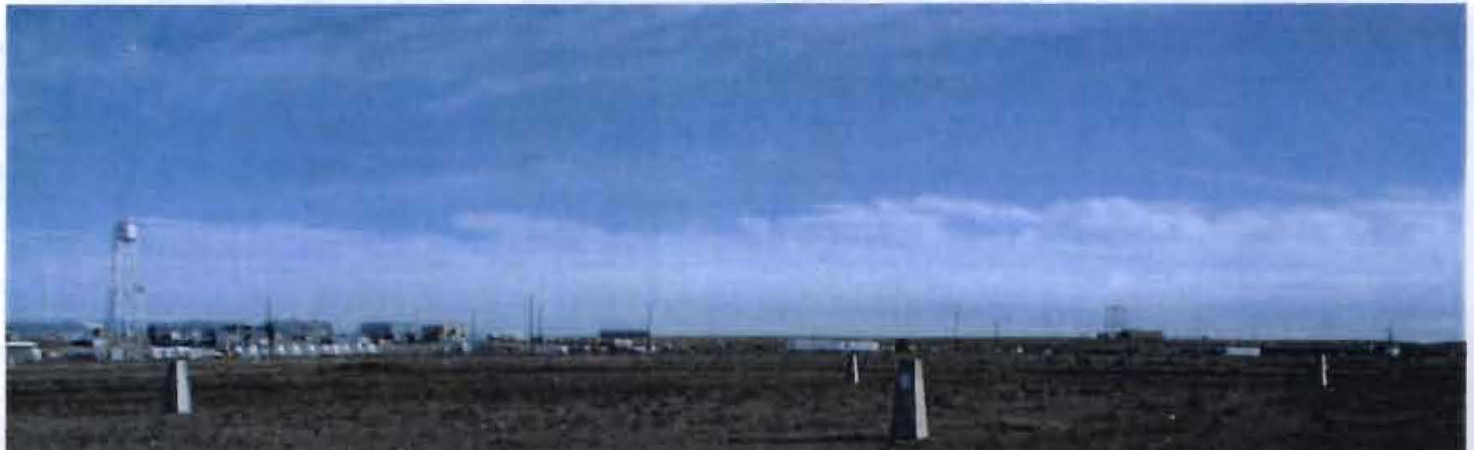

$12 / 03 / 2003$

24. CAU 424 Area 3 Landfill Complexes Landfill Cell A3-4, looking northeast

D-14 


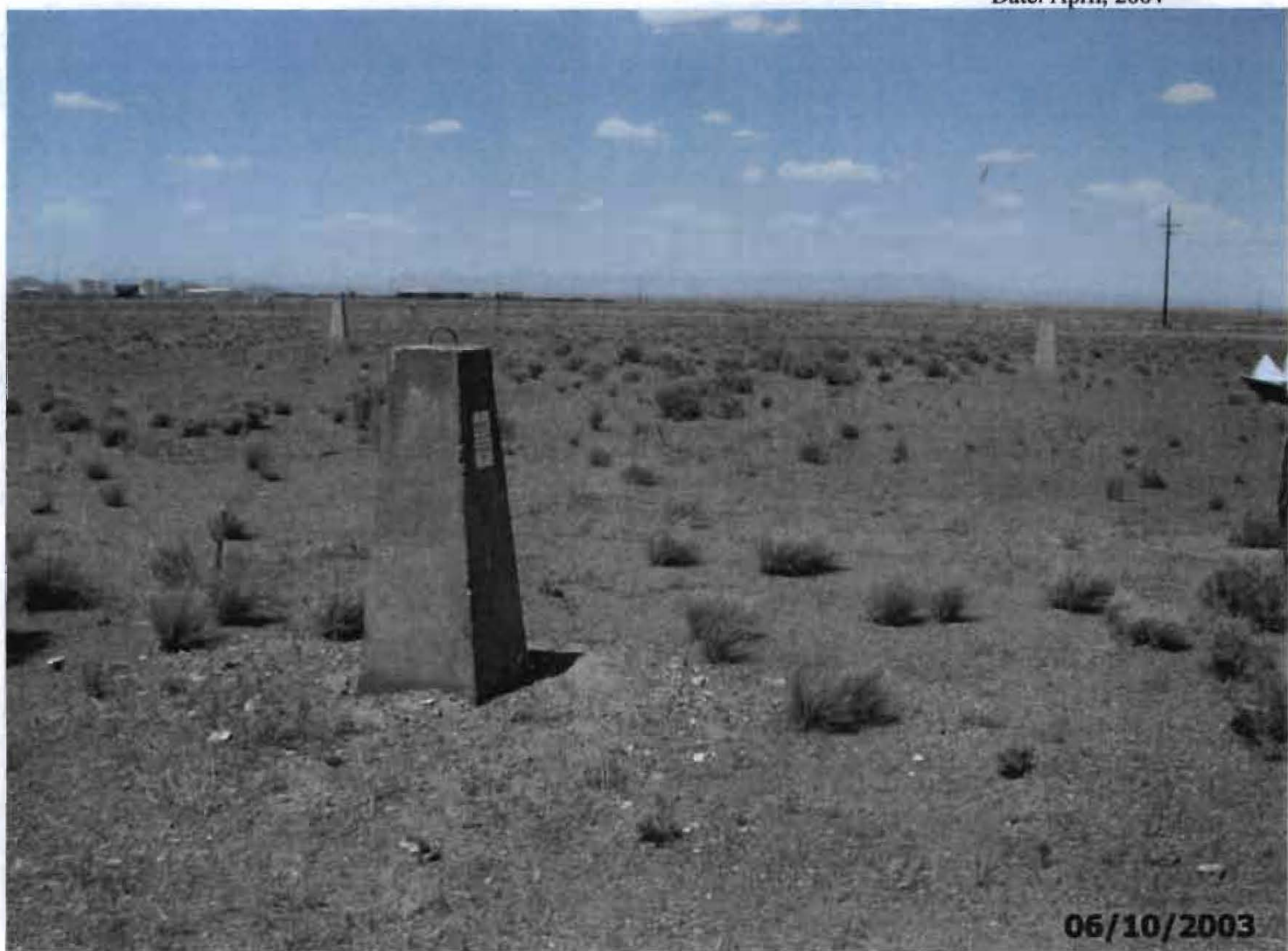

25. CAU 424 Area 3 Landfill Complexes Landfill Cell A3-6, looking northwest

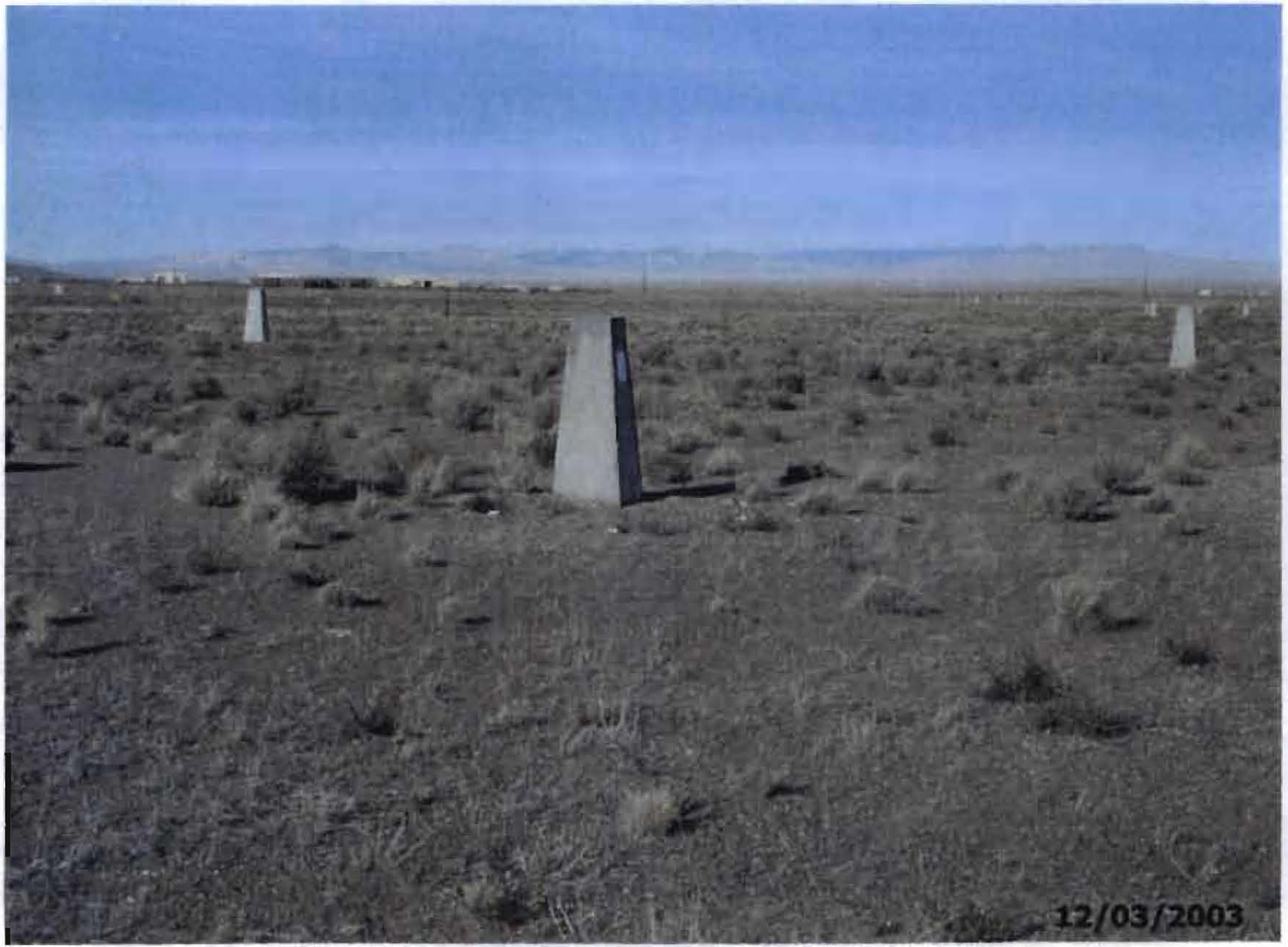

26. CAU 424 Area 3 Landfill Complexes Landfill Cell A3-6, looking northwest

D-15 


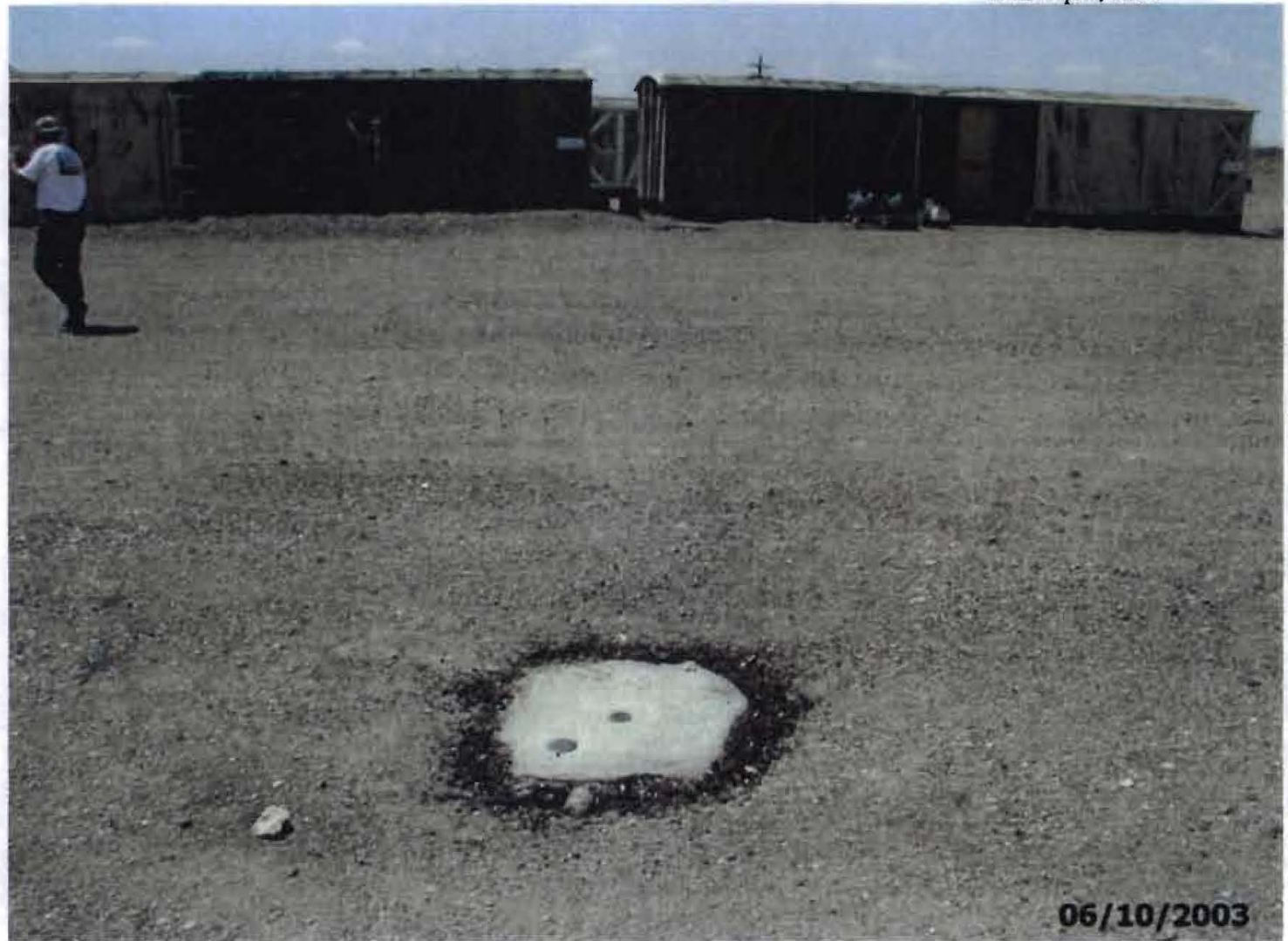

27. CAU 424 Area 3 Landfill Complexes Landfill Cell A3-8, looking west

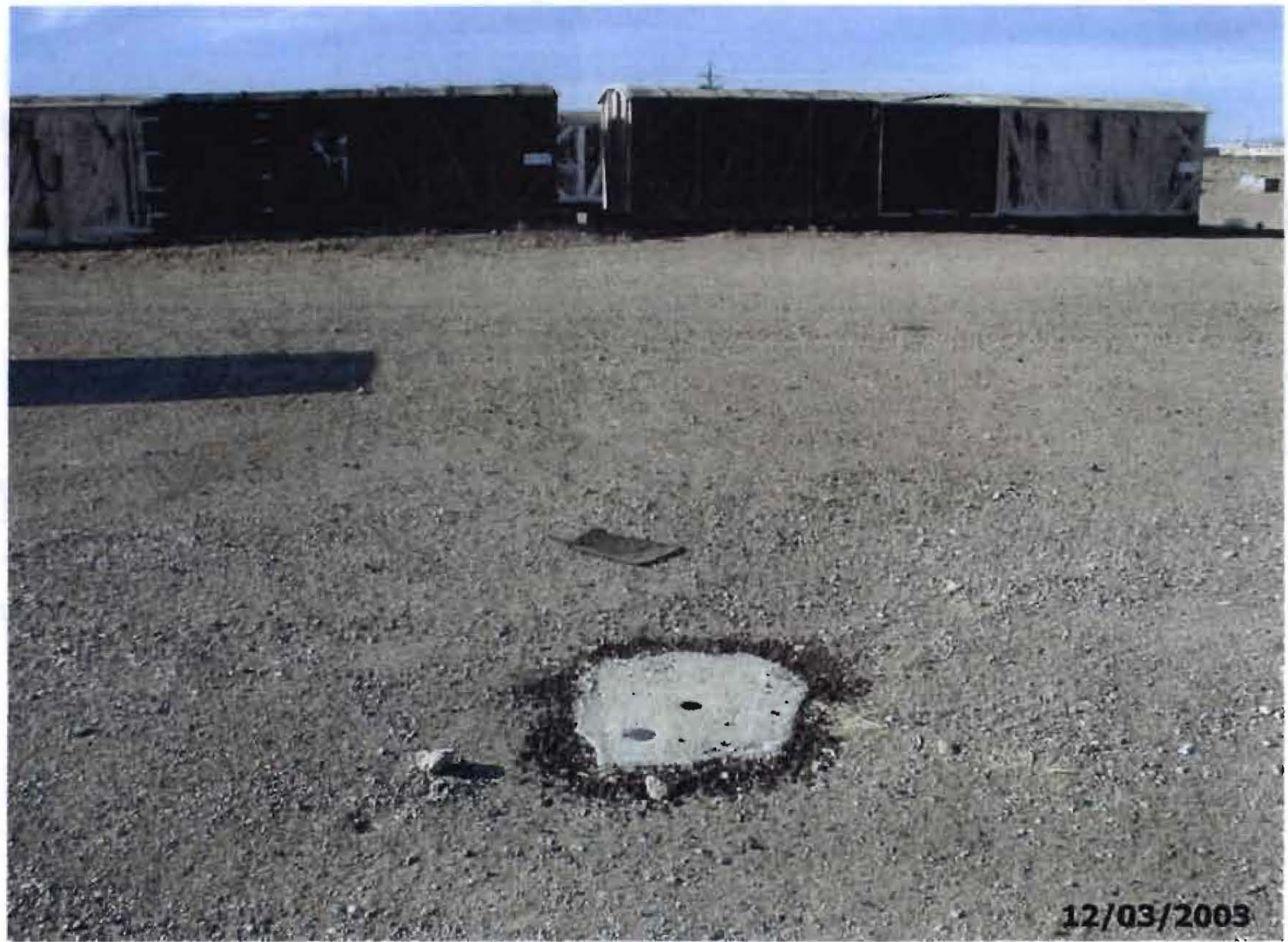

28. CAU 424 Area 3 Landfill Complexes Landfill Cell A3-8, looking west 


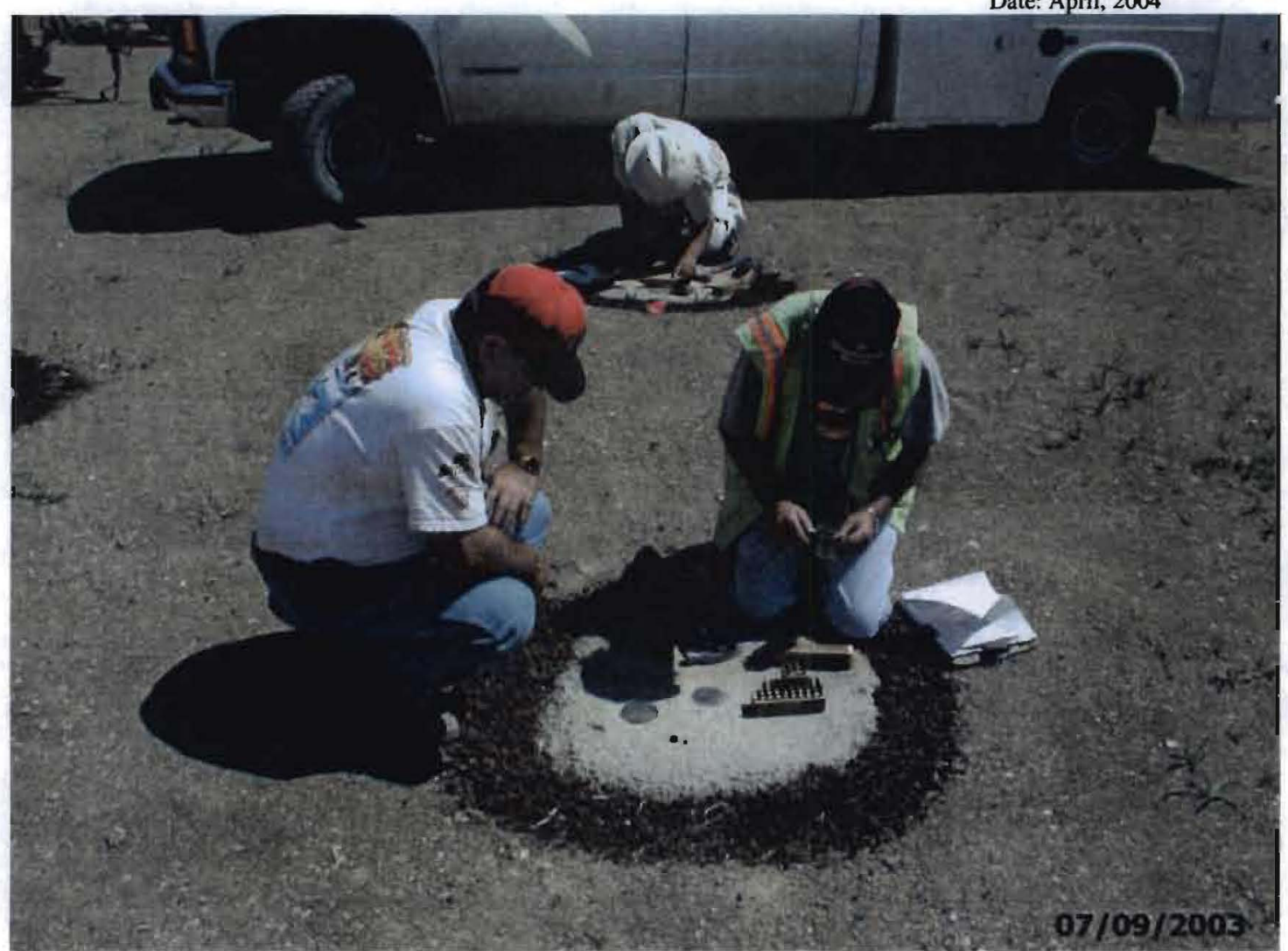

29. CAU 424 Area 3 Landfill Complexes Landfill Cell A3-3, July 2003 repairs (stamping land-use restriction coordinates on monument)

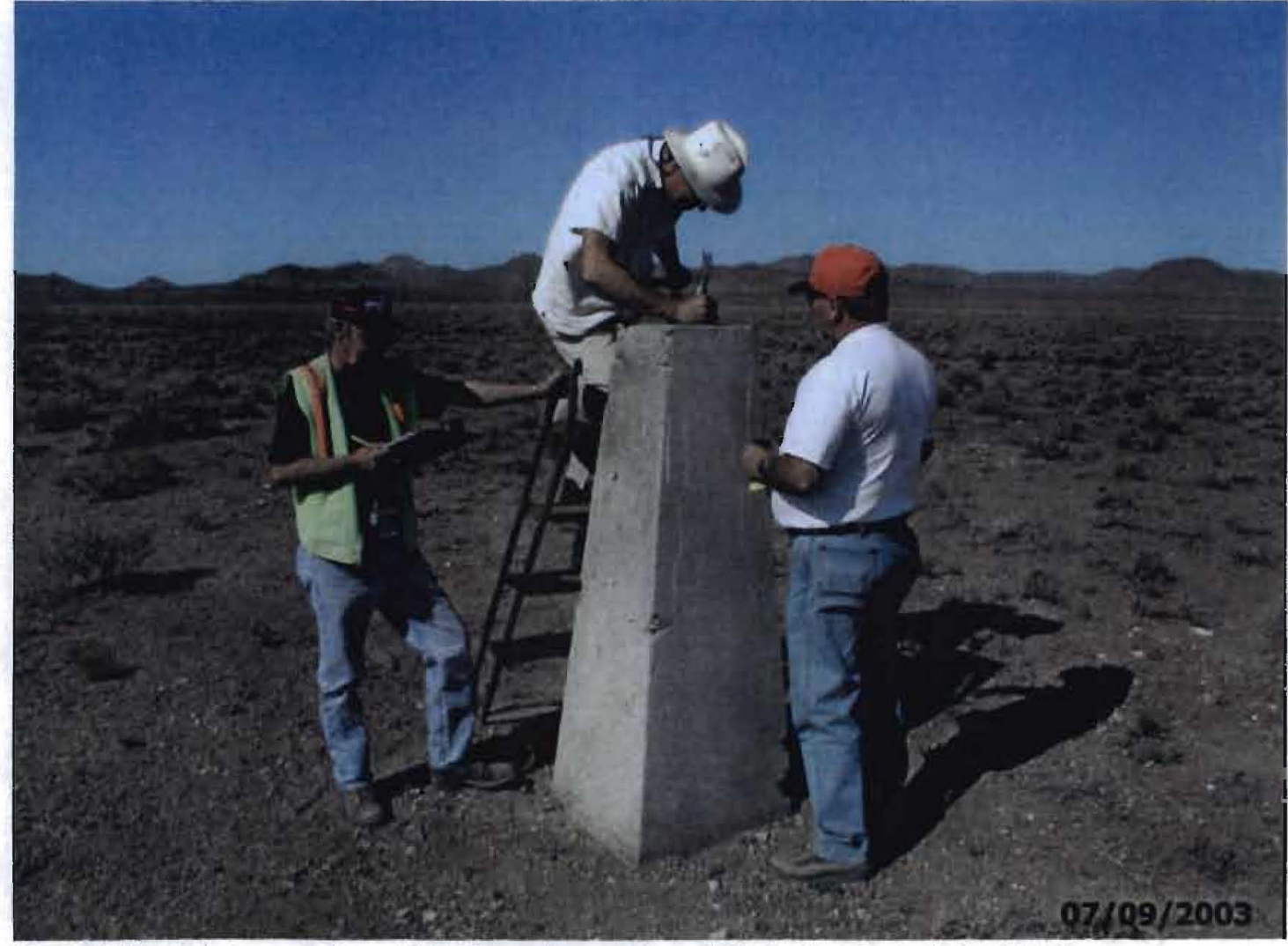

30. CAU 424 Area 3 Landfill Complexes Landfill Cell A3-4, July 2003 repairs (stamping land-use restriction coordinates on monument)

D-17 


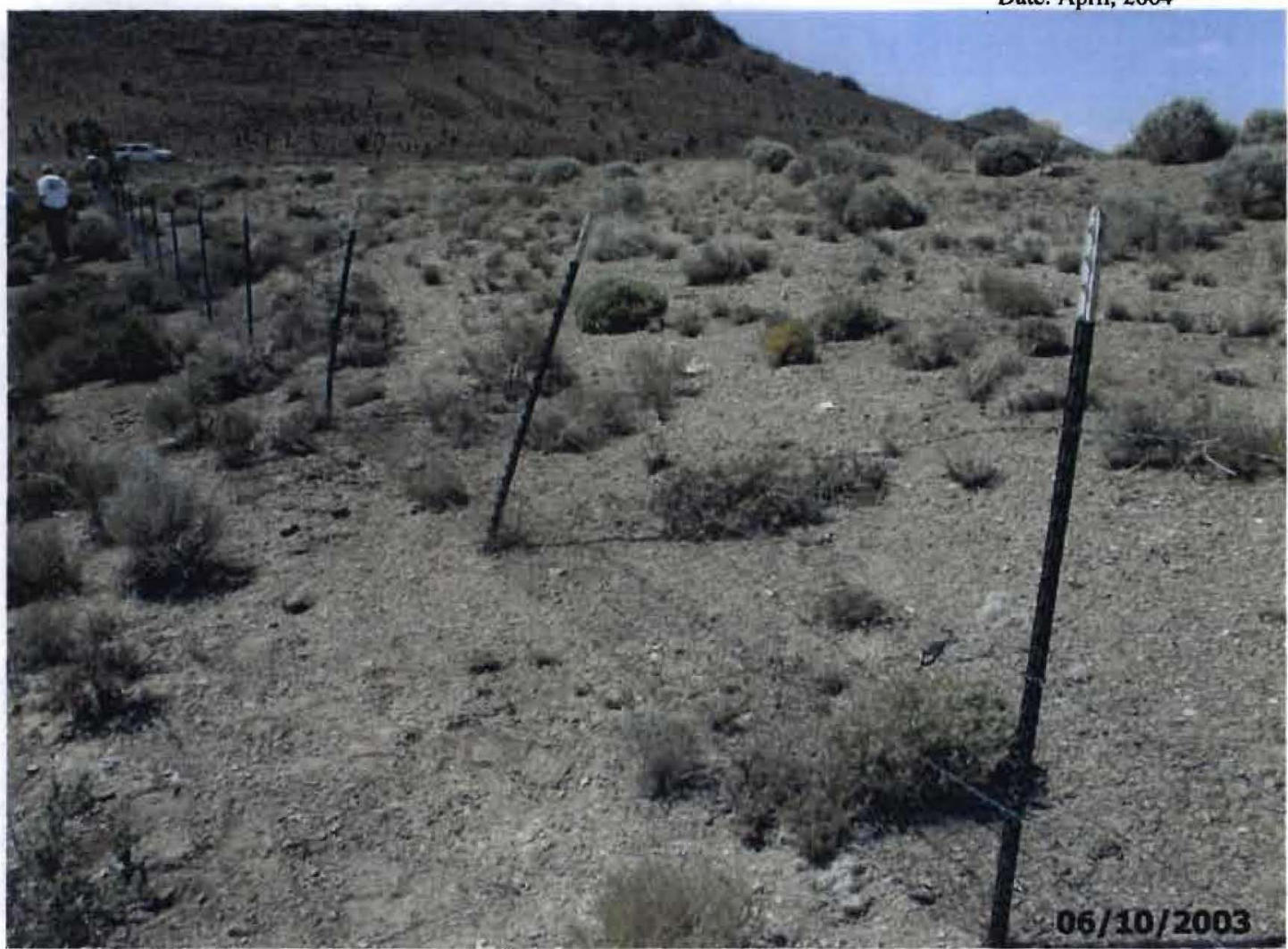

31. CAU 426 Cactus Spring Waste Trenches, looking northwest (damaged fencing)

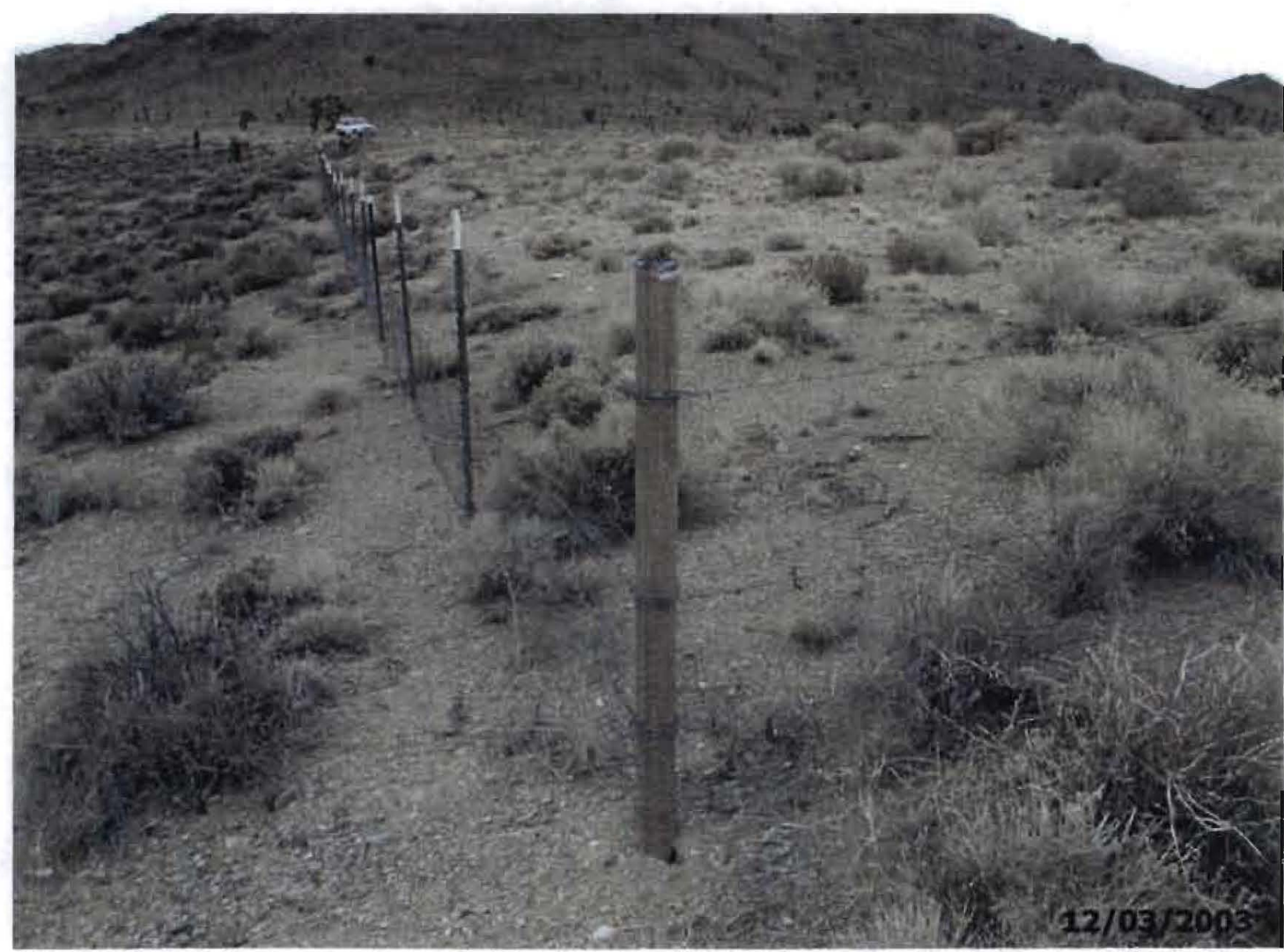

32. CAU 426 Cactus Spring Waste Trenches, looking northwest (fencing repaired) 
Date: April, 2004

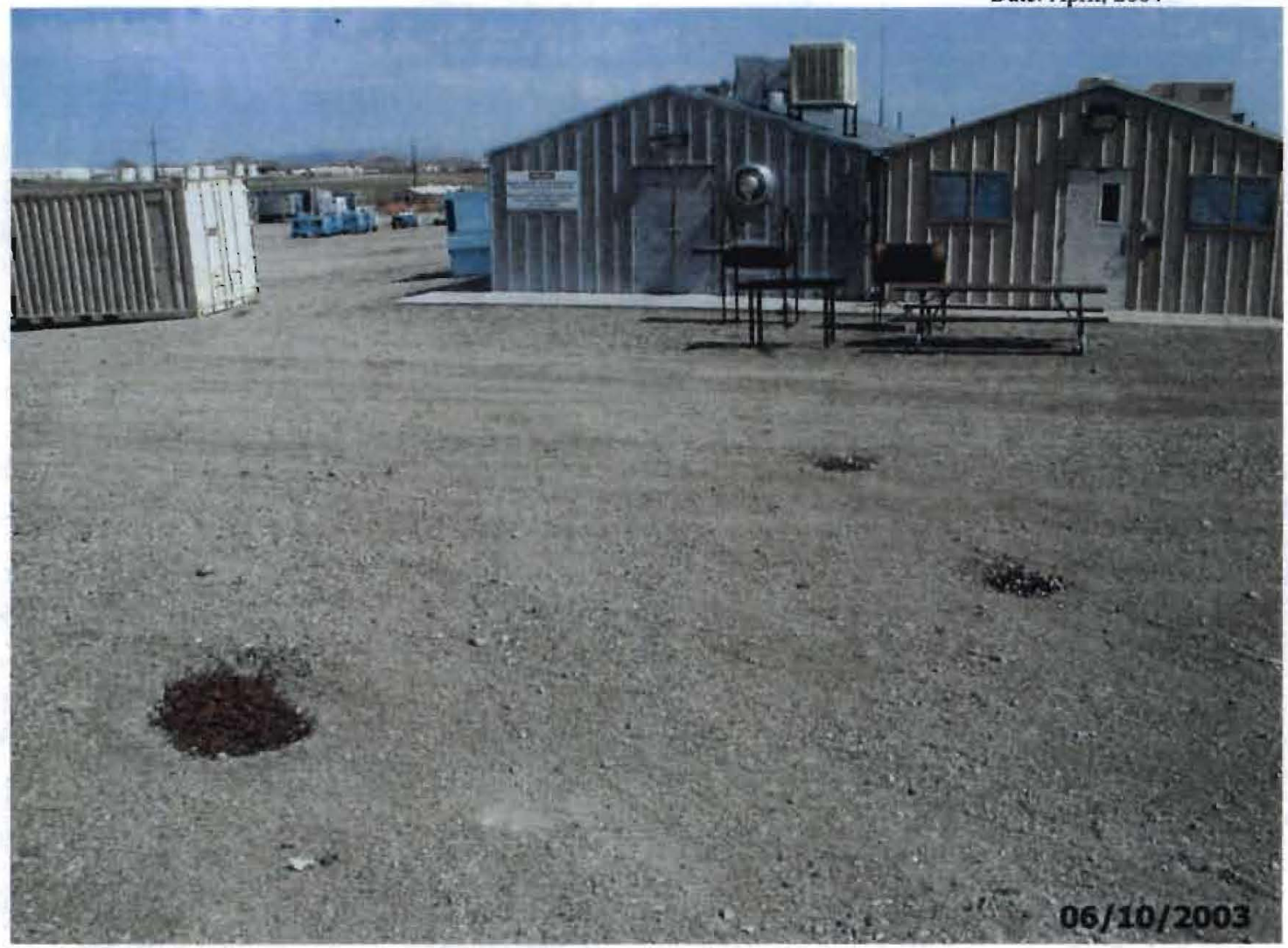

33. CAU 427 Area 3 Septic Waste Systems 2, 6, looking north

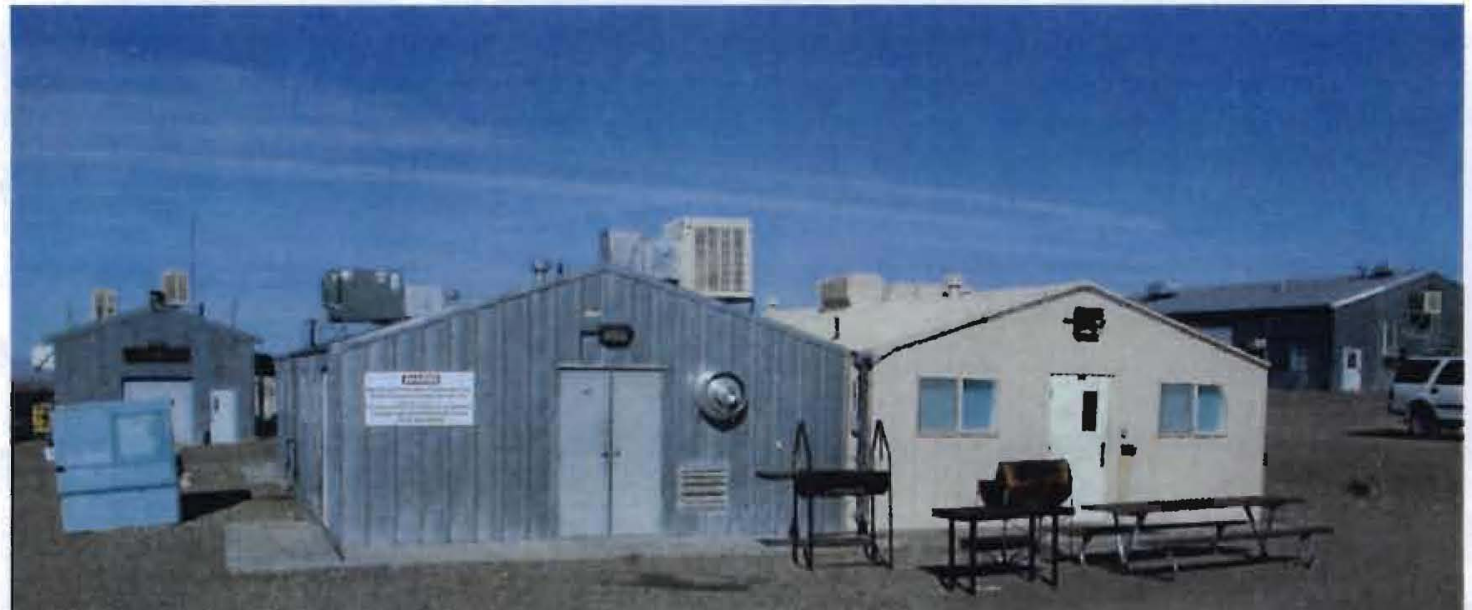

$12 / 03 / 2003$

34. CAU 427 Area 3 Septic Waste Systems 2, 6, looking north (monuments are in foreground shadow) 


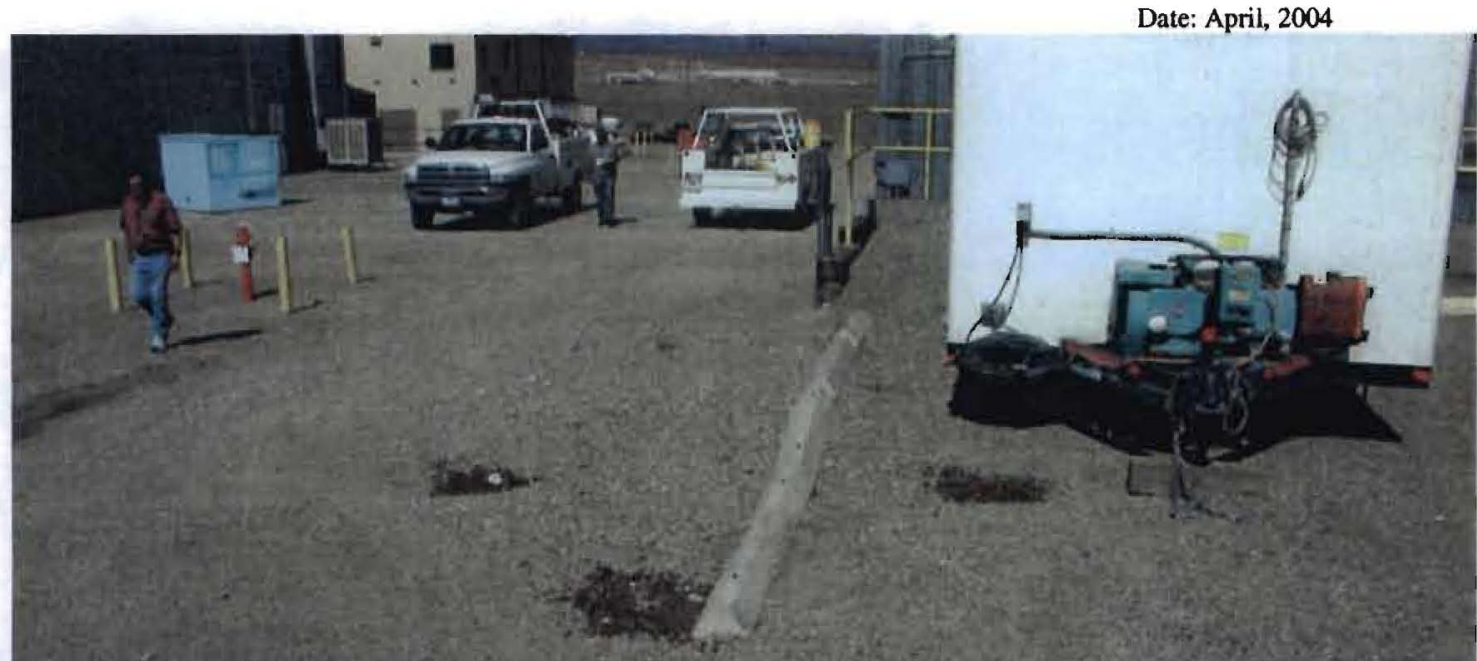

$06 / 10 / 2003$

35. CAU 427 Area 3 Septic Waste Systems 2, 6, looking west

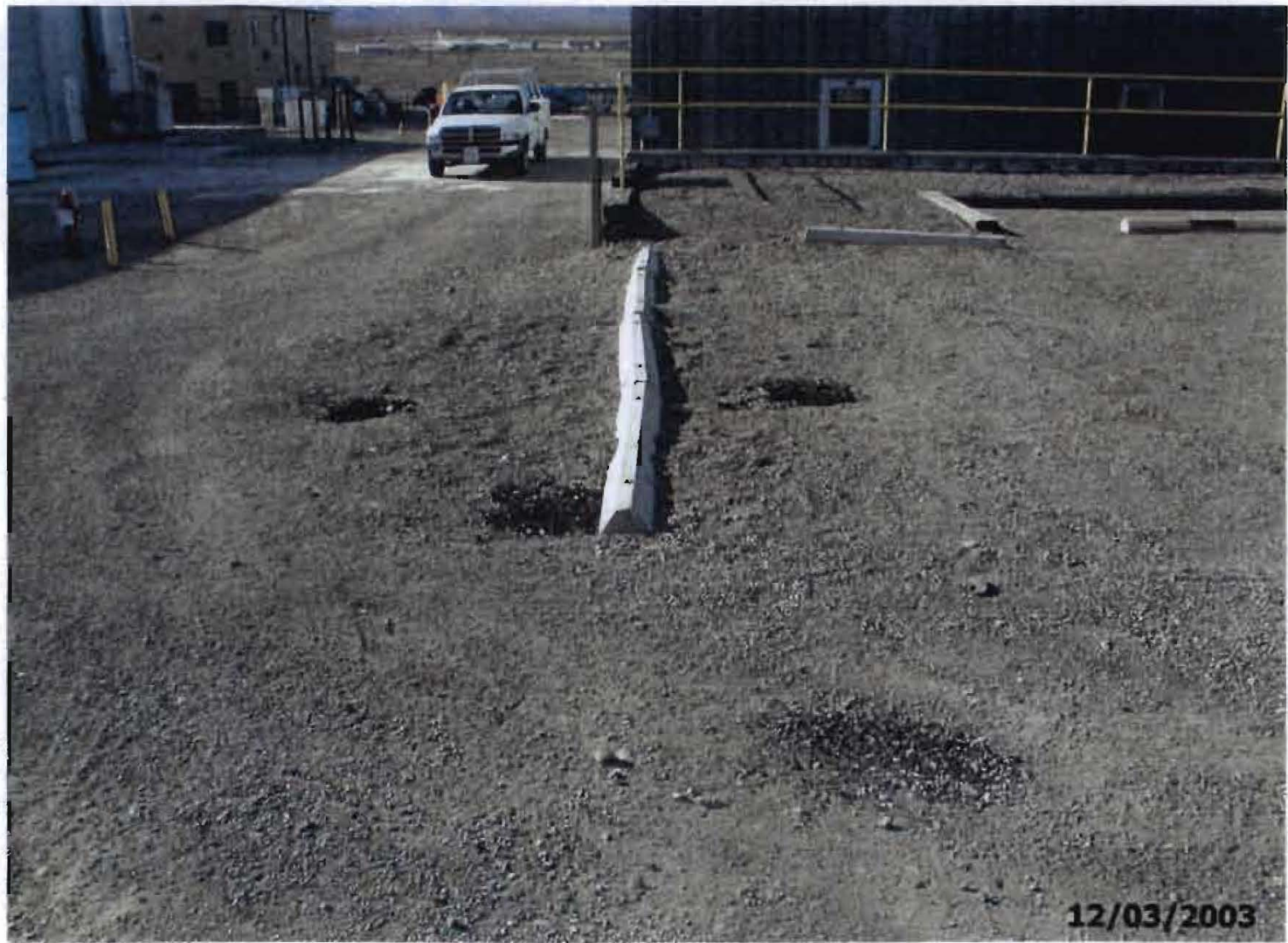

36. CAU 427 Area 3 Septic Waste Systems 2, 6, looking west 


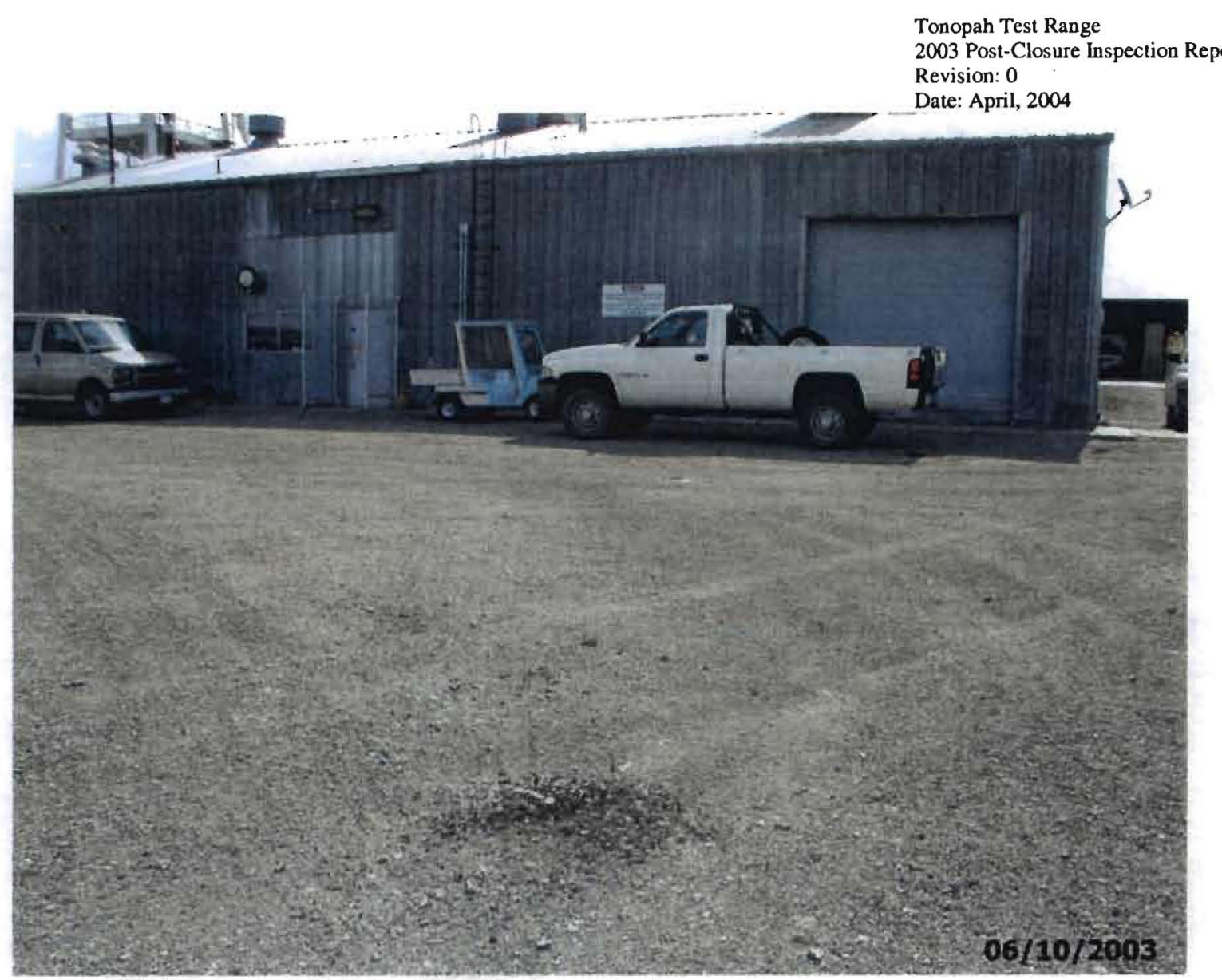

37. CAU 427 Area 3 Septic Waste Systems 2, 6, looking east
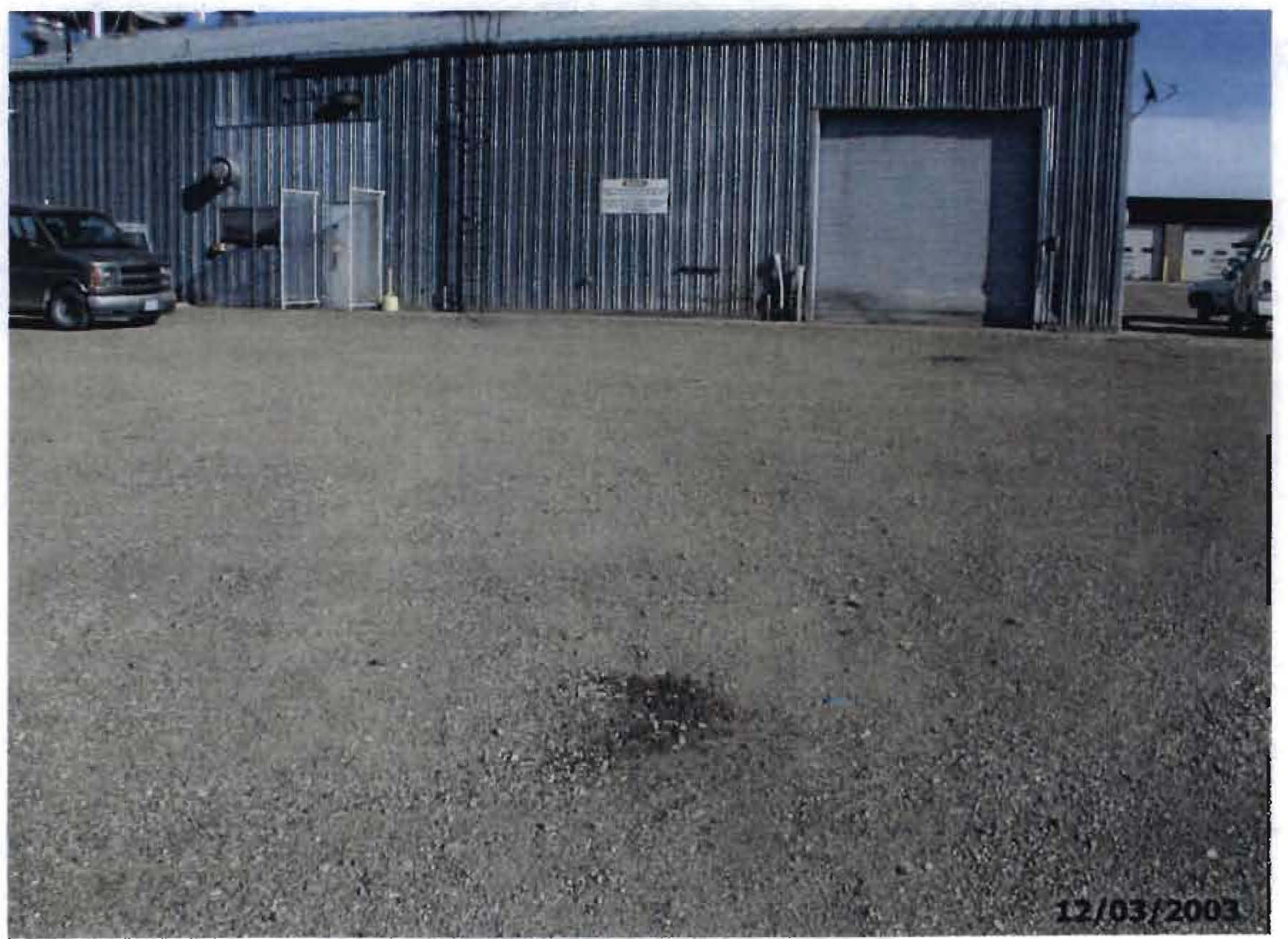

38. CAU 427 Area 3 Septic Waste Systems 2, 6, looking east

D-21 


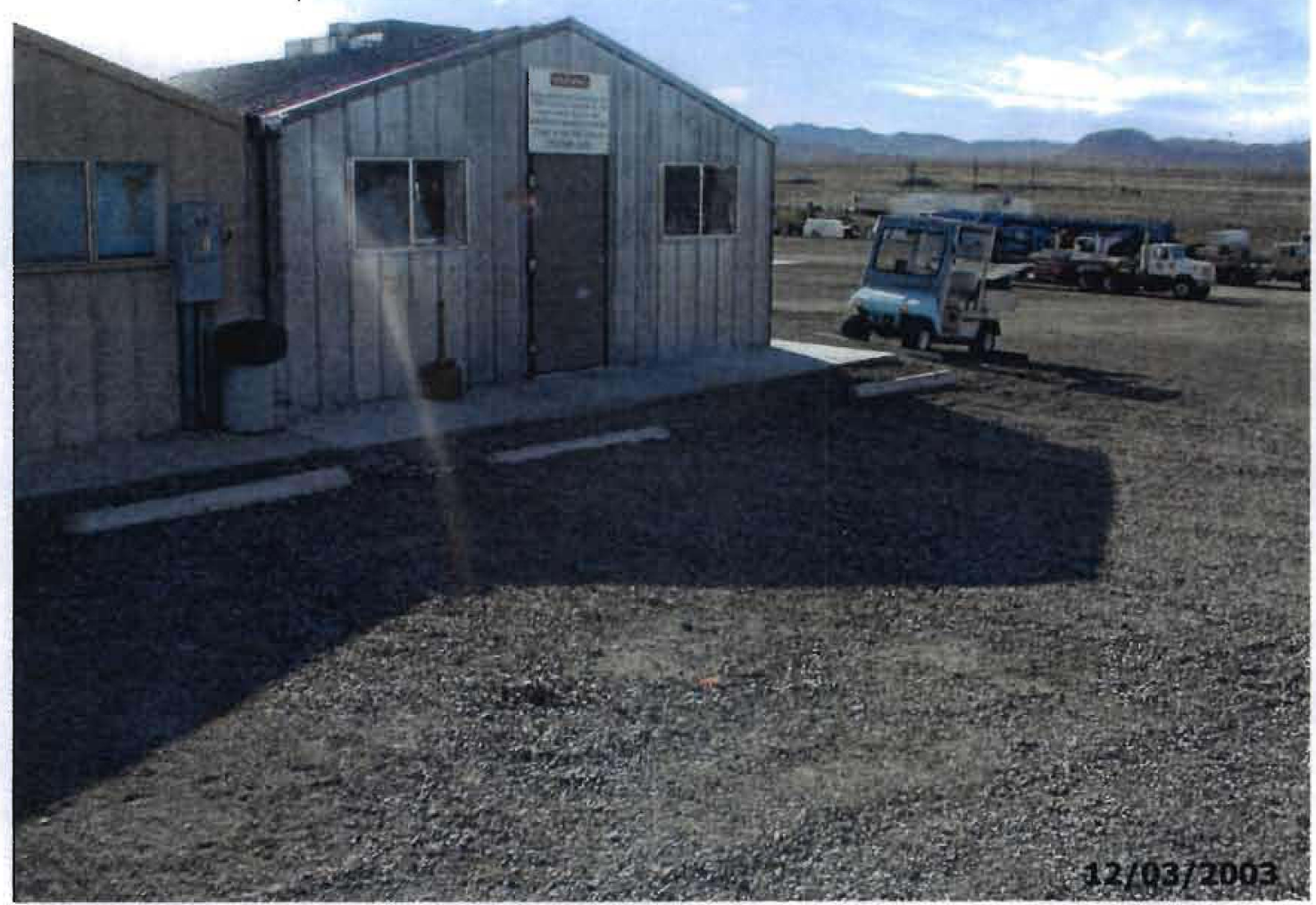

39. CAU 427 Area 3 Septic Waste Systems 2, 6, looking west (new use restriction sign on Bldg 0307T)

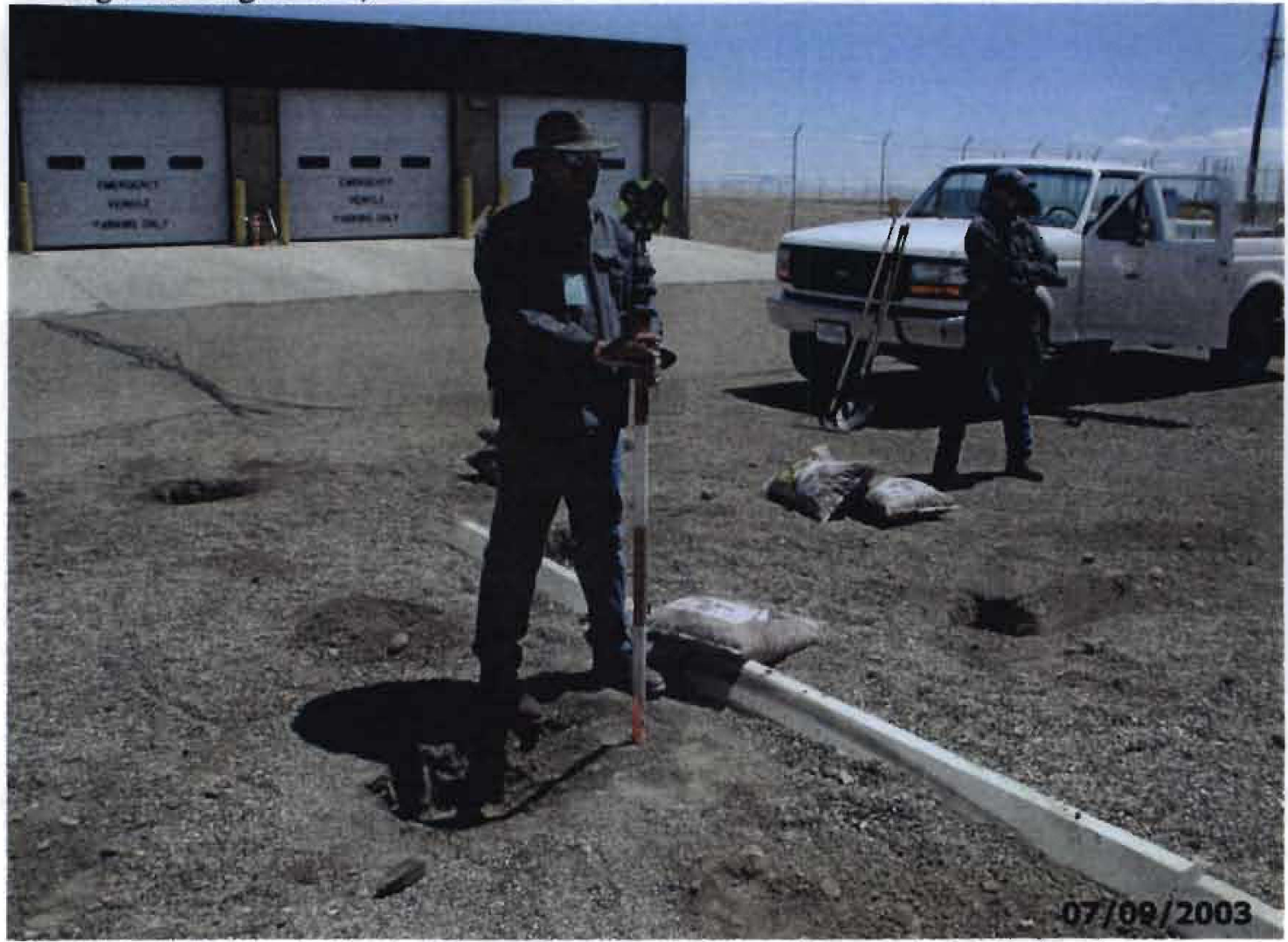

40. CAU 427 Area 3 Septic Waste Systems 2, 6, looking southeast (maintenance and measurement data collection) 
Date: April, 2004

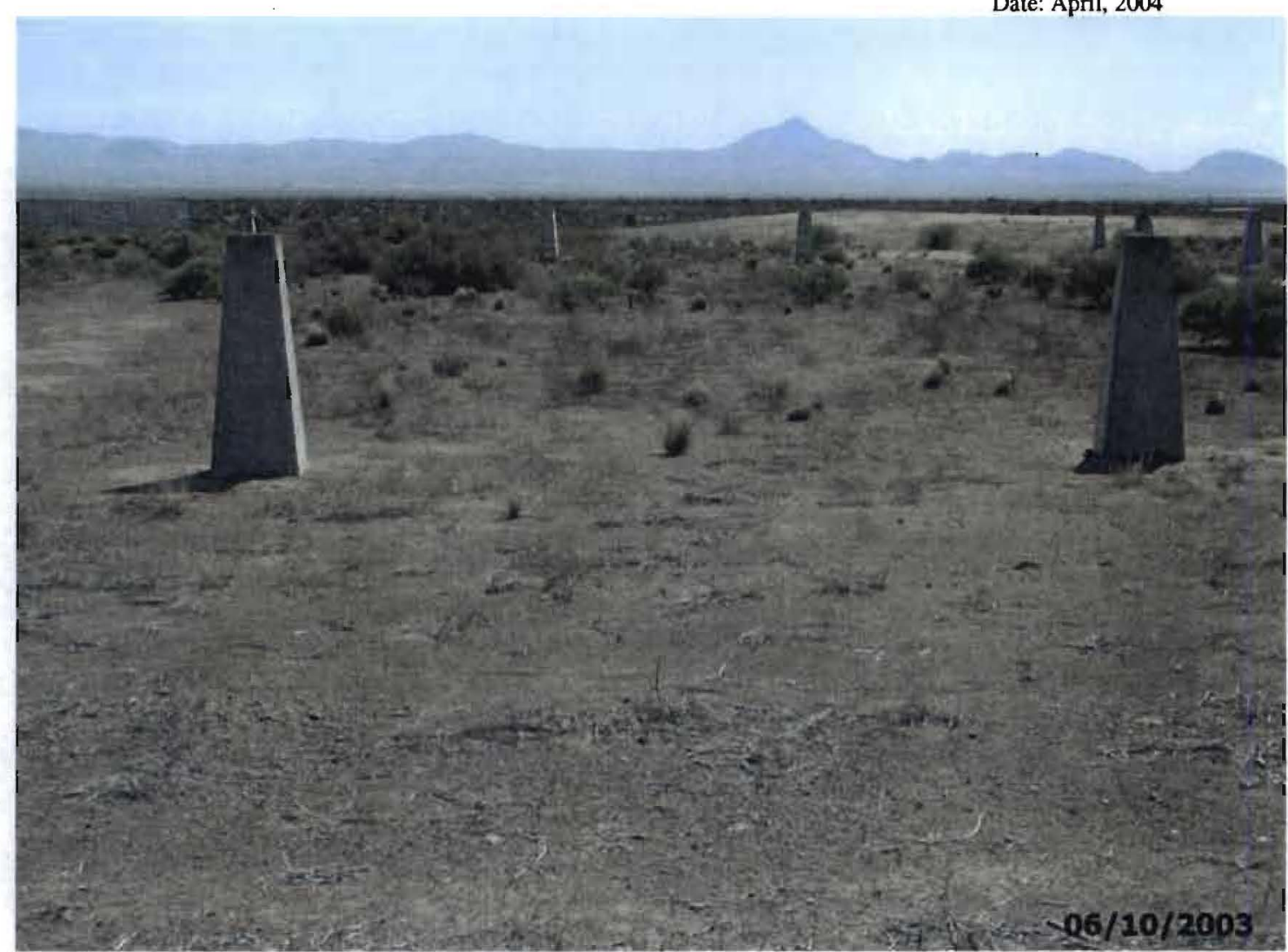

41. CAU 453 Area 9 UXO Landfill, looking west

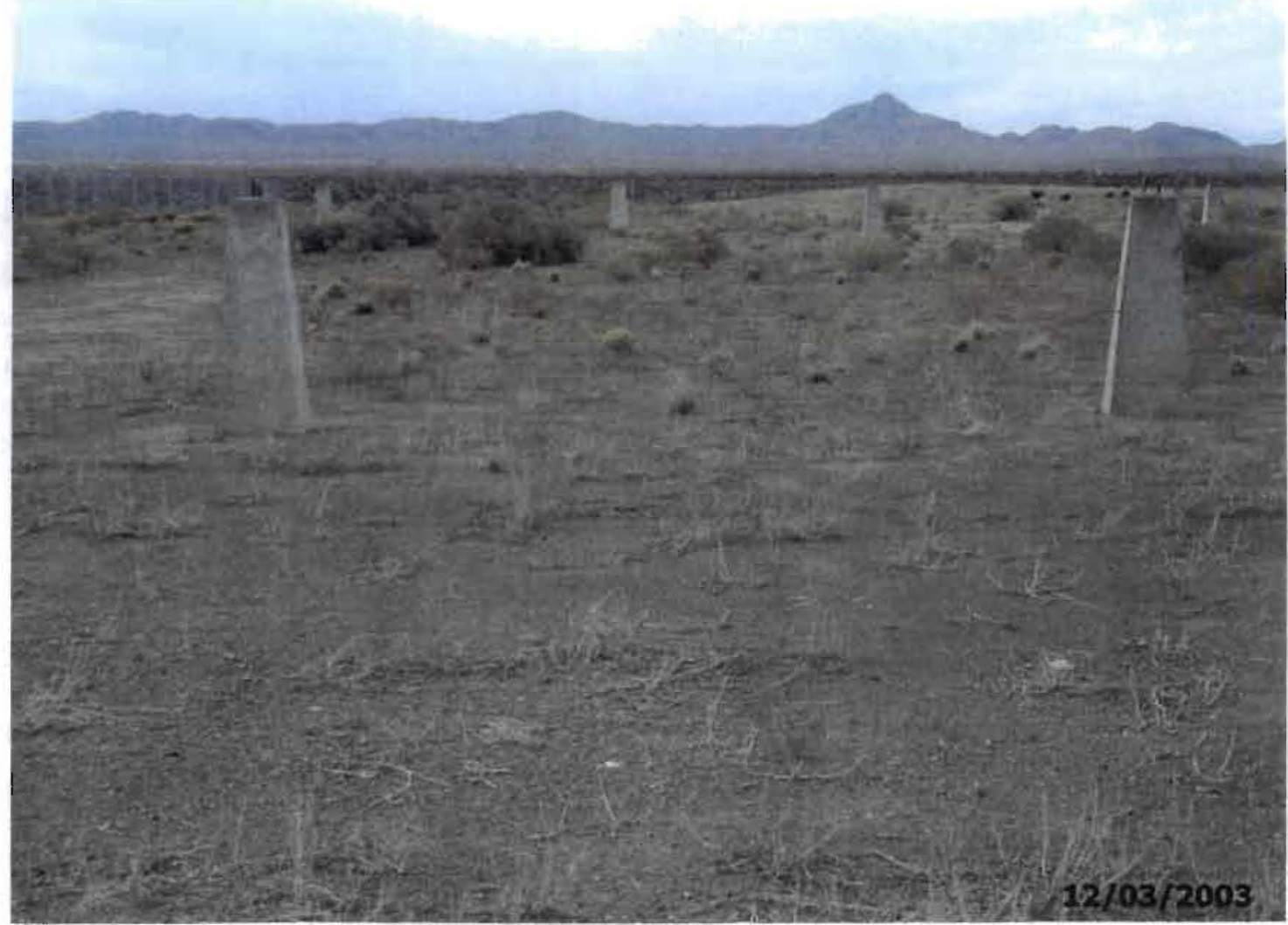

42. CAU 453 Area 9 UXO Landfill, looking west 


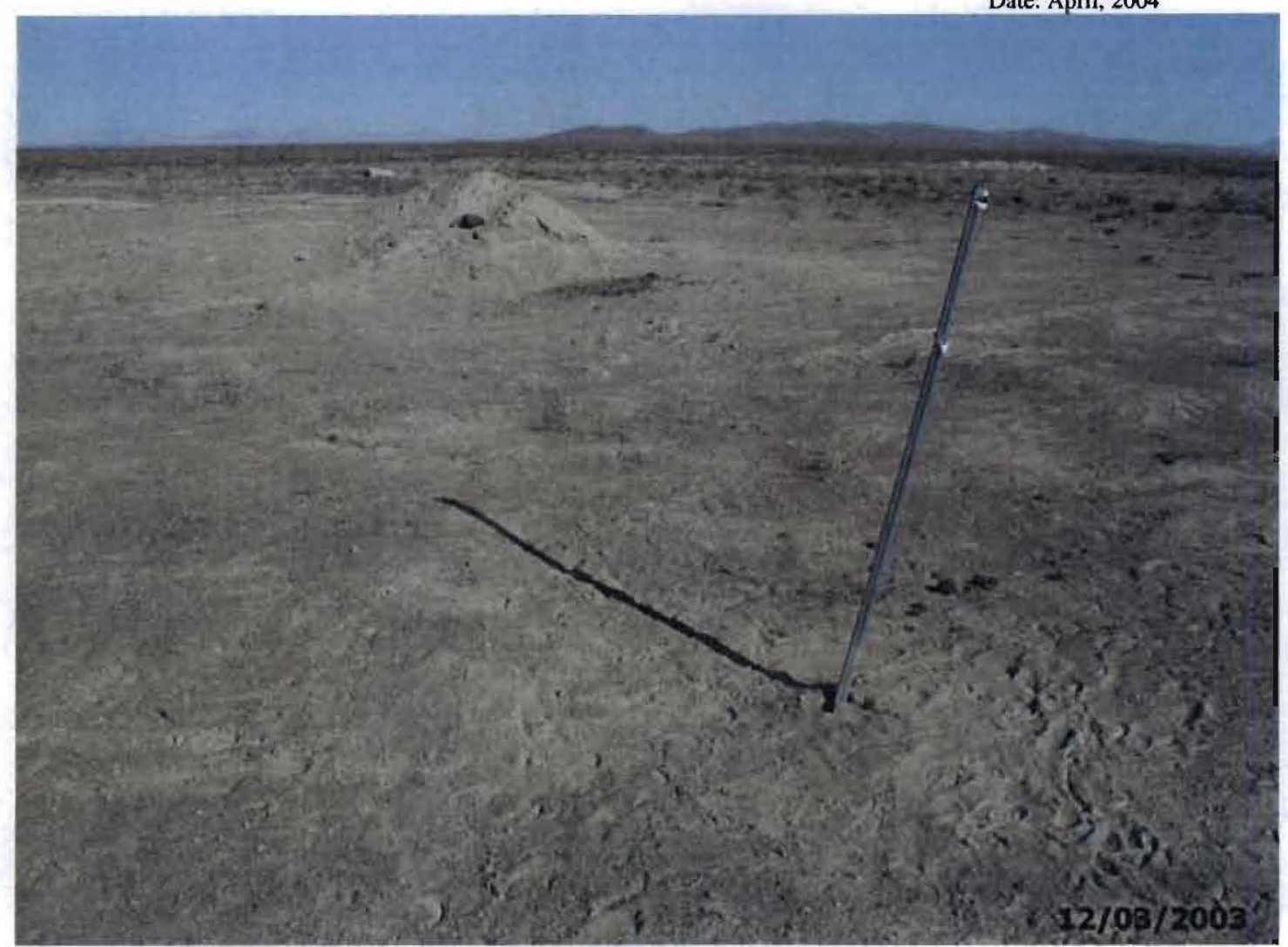

43. CAU 487 Thunderwell Site, looking west (Anomaly A-17)

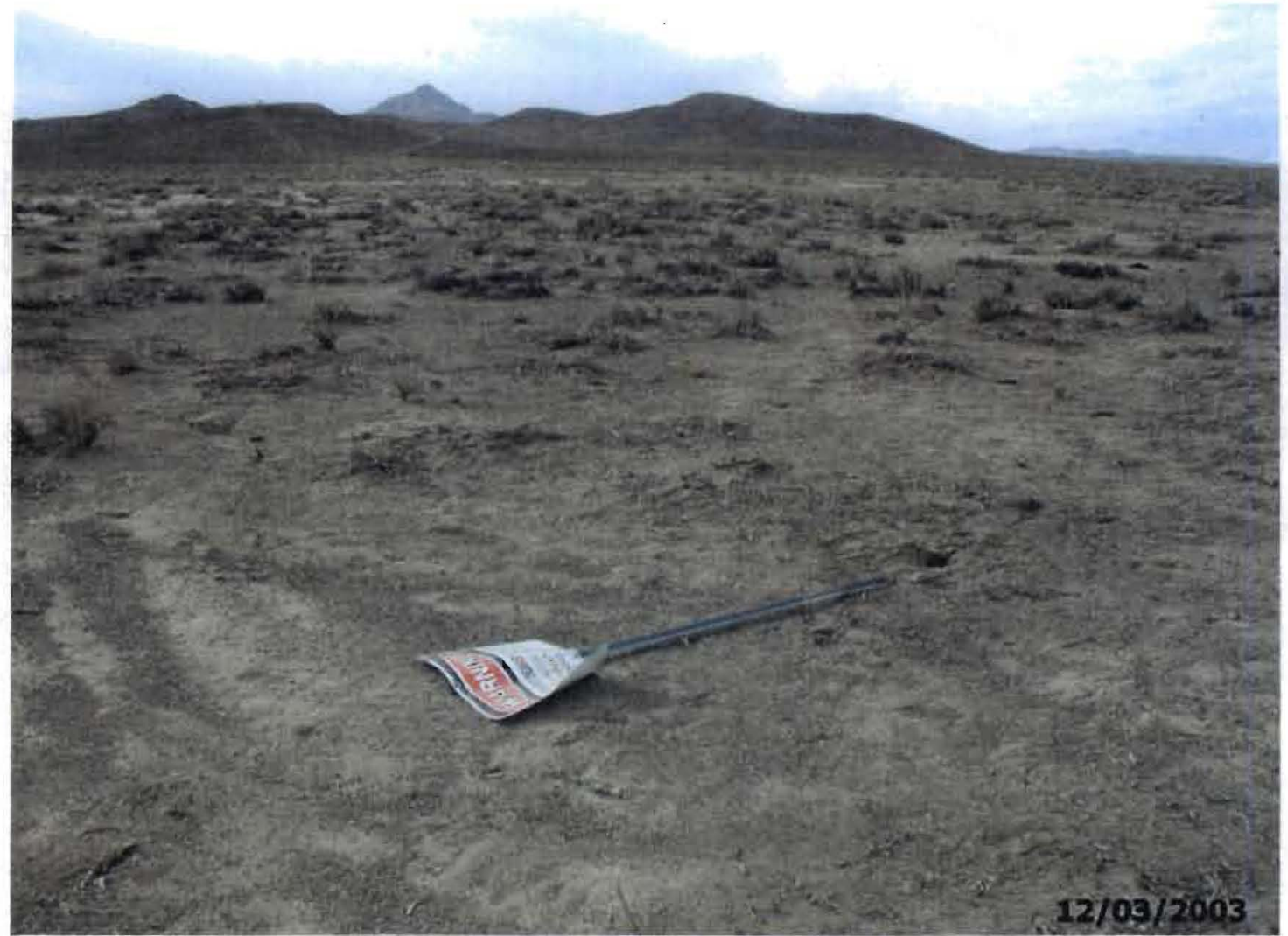

44. CAU 487 Thunderwell Site, looking south (Anomaly A-8) 
Date: April 2004

\section{ATTACHMENT E}

\section{POST-CLOSURE VEGETATIVE MONITORING REPORT (SEPTEMBER 2003)}




\title{
POST CLOSURE MONITORING REPORT \\ TONOPAH TEST RANGE CLOSURE SITES \\ SEPTEMBER 2003
}

\begin{abstract}
Background
Work at Corrective Action Units (CAU) 400-Five Points Landfill and Bomblet Pit; 404Rollercoaster Sewage Lagoons; and 426-Cactus Springs Waste Trenches was completed during the summer of 1997. In the fall of 1997 the closure sites were seeded with a mix of seeds of native shrubs and grasses. Each site was mulched with straw and the straw was crimped into the soil. Sites were protected from grazing animals (primarily horses and rabbits) by installing a four-strand barbed wire fence with two-foot high chicken wire fence along the base. In the fall of 2000 the cover at CAU 407-Rollercoaster RADSAFE area was revegetated with a mix of native shrubs and grasses. The site was mulched with a straw-mulch and the mulch crimped into the soil. The site was fenced with several strands of wire with the primary purpose of preventing inadvertent entry to site and preventing horses from entering the site.
\end{abstract}

Site monitoring began in 1998 for all the sites except CAU 407-Rollercoast and continued in 2000, 2002 and 2003. Monitoring in 1998 was designed to determine if germination of seededplant species had occurred and included plant density estimates and photographic documentation. Monitoring in subsequent years evaluated plant establishment, evaluated long-term vegetation survival, and compared plant cover and density with adjacent reference areas (undisturbed sites). Concurrently with vegetation monitoring, wildlife use of the site and the erosion condition of the soil were evaluated. This report documents monitoring efforts conducted in September 2003 at CAUs 400, 404, 406 and 426 all located on the Tonopah Test Range in central Nevada.

\section{Methodology}

BN Ecological Services staff scientists inspected CAU 400-Five Points Landfill \& Bomblet Pit, CAU 404-Rollercoaster Sewage Lagoons, CAU-407 Rollercoaster RADSAFE area, and CAU 426-Cactus Springs Waste Trenches on September 8 and 9,2003 . Overall conditions related to the vegetative cover as described in the post-closure monitoring checklist were recorded. Scientists collected cover and density data for plant species that had established on the site, noted wildlife usage of the site, and recorded the soil erosion condition. Cover data were taken using a cover point projection device (Figure 1) at pre-determined intervals along linear transect. Four cover points were taken at the starting point of each quadrat. Plant density was determined by recording the number of plants found within a pre-determined number of $1-$ meter $(\mathrm{m})$ by $1-\mathrm{m}^{2}$ quadrats.

Plant density and cover were estimated for reference areas located adjacent to the closure site. The data collected from the reference areas are used as standards in evaluating revegetation success. The number of quadrats

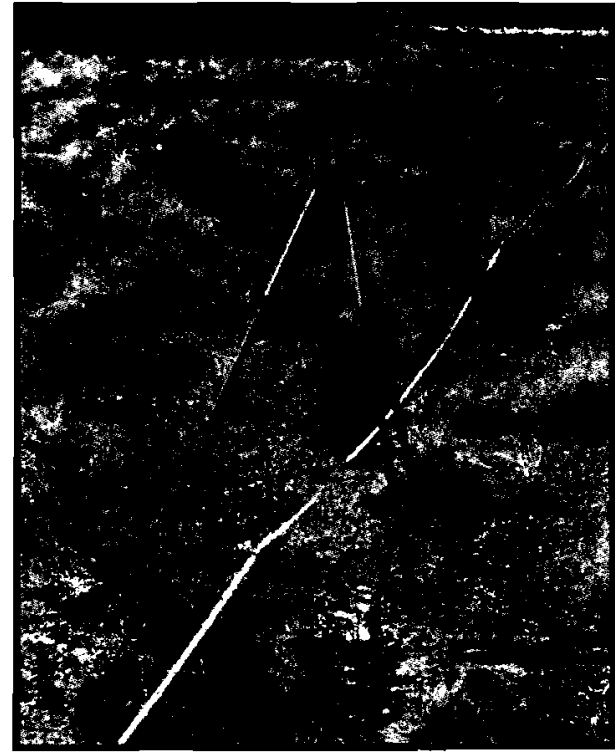

Figure 1. Cover point project device used to estimate plant cover. 
and cover points sampled at each reference area was equal to the number of quadrats and cover points sampled on the closure site. For the CAU 404-Rollercoaster and CAU 426-Cactus Springs sites, where both the staging area and cover cap were sampled, the number of quadrats and cover points were equal to those used to sample the staging area.

Site specific sampling designs were as follows:

CAU 400-Five Points Landfill - Originally 20 quadrats were placed at $4 \mathrm{~m}$ intervals along an 80-m transect, running diagonally across the site from NW to SE. However 70$80 \%$ of this transect was covered with water. A new transect was set up that began on the far eastern edge of area near the center about 10 meters from the fence and on south side of a small channel. The transect runs east to west, ending at a corner fence post where fence bends to south. The southeastern section of the original transect was unaffected by water cover and was sampled as in previous years.

Reference Area - Starting point is about $10 \mathrm{~m}$ north of north fence and $10 \mathrm{~m}$ east of road and ends about $30 \mathrm{~m}$ north of brace post. Transect parallels the north fence of the closure site. Transect is $120 \mathrm{~m}$ long with a quadrat placed every $4 \mathrm{~m}$ starting at west end.

CAU 400-Bomblet Pit - 20 quadrats were sampled at $4 \mathrm{~m}$ intervals along an $80-\mathrm{m}$ transect that starts in northwest section of plot and continues in a southeasterly direction. Reference Area - Starting rebar is about 50 m east of gate and transect parallels east fence. Transect is $80 \mathrm{~m}$ long and 20 quadrats are placed at 4-m intervals beginning at northern end.

CAU 404-Roller Coaster Sewage Lagoons - 50 quadrats are placed at $3 \mathrm{~m}$ intervals along a 150-m transect, starting in southwest corner of plot and continuing in southeast direction. Along the cover cap 20 quadrats were placed at $2.5 \mathrm{~m}$ interval along $50-\mathrm{m}$ transect going from northeast to southwest.

Reference Area - Starting rebar is about $23 \mathrm{~m}$ northwest of gate and somewhat parallel to fence. The transect is $150 \mathrm{~m}$ long with 50 quadrats placed at $3-\mathrm{m}$ intervals, starting at southern end of transect on continuing north-northwest.

CAU 426-Cactus Springs Staging Area - 30 quadrats were placed at 2-m intervals along a $60-\mathrm{m}$ transect beginning at west end of the staging area. 15 quadrats were sampled at 2-m intervals along a 30-m transect located on the cover cap. The transect runs northeast to southwest.

Reference Area-Starting point is about $25 \mathrm{~m}$ north of the gate and parallels north fence. Transect is $60 \mathrm{~m}$ long with 30 quadrats placed at $2-\mathrm{m}$ intervals in a west to east direction.

CAU 407-Rollercoaster RADSAFE Area - Only observations from outside the fence were made on this site. Photographs were taken, but no field data i.e. cover or density, were taken. 
Wildlife usage of the site was determined by noting any wildlife or wildlife sign, i.e. burrows, observed during sampling. The erosion condition of the soil over the site in general was determined using a modified Bureau of Land Management erosion condition classification (Appendix E).

\section{Results}

The results of field monitoring in September 2003 are summarized for each of the closure sites in the following sections. Overall plant cover was higher on the closure sites than on the corresponding reference areas. Plant densities were also higher for the two CAU 400 sites and CAU 404, but lower on the CAU 407 site than for the reference areas. Appendices to this report contain a summary of plant cover and density data (Appendix A), the Post-Closure Monitoring Checklists (Appendix B), photographic reference points (Appendix C), and a list of scientific names and common names of plant species referred to in this report (Appendix D).

CAU 400-Five Points Landfill - Cover and density data were collected from areas not covered by water. In the water covered area plants are either under water or covered with sediment. Only plant skeletons remain in these areas (figure 2). The areas not covered by water still show good plant growth. Both plant cover and density in these areas are higher than cover and density in the reference area. The percentage of grass and shrub cover is about equal this year, whereas in previous years grasses contribute about twice as much cover as shrubs. The reduction in grass cover is probably a result of the continued drought in this region. Precipitation received this year was spotty and relatively light and was not sufficient for grass growth. Plant cover is about a third less than it was last year, but this is more a factor of time of sampling than actual loss of vegetation. Sampling last year was during a period of peak plant growth, whereas sampling this year followed a third year of below normal precipitation plus a long hot summer. Summer rains received this summer will recharge the dry soils and provide needed moisture long-term survival of both shrubs and grasses.

Plant density is still slightly higher on the closure

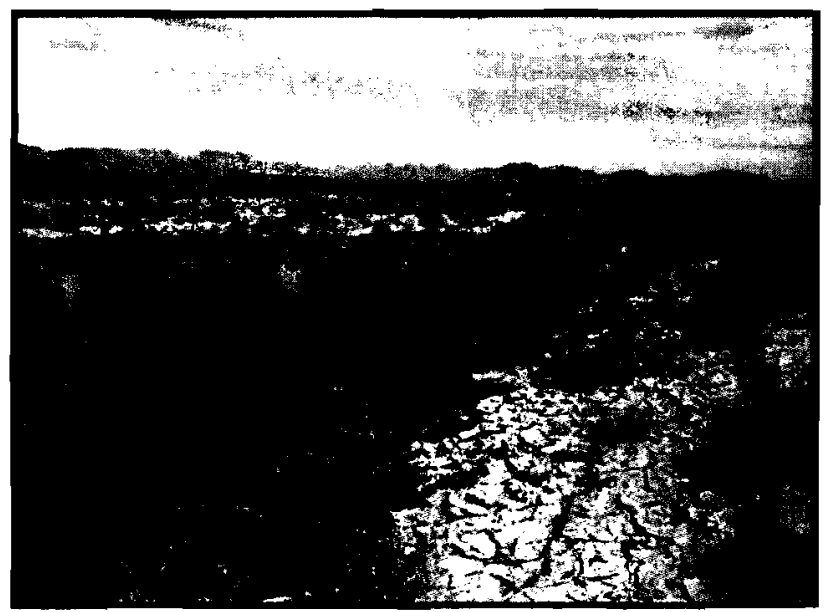

Figure 2. CAU 400-Five Points Landfill was flooded during the summer of 2003 . About $40 \%$ of the site was covered with water for extended periods of time. sites than on the reference area. Densities are also about the same as they were last year suggesting that the same number of plants are present, they just aren't as big. Fourwing saltbush is the most common shrub and Indian ricegrass and bottlebrush squirreltail were the most common grasses. There were a couple annual plant species present, probably taking advantage of the recent rains in the area.

There were no signs of herbivory on the site. There is an abundance of small mammal burrows over much of the site. Erosion, of course, was apparent along the main channel. The fence on the eastern edge that crossed the channel has been slightly covered with sediment, but there was no evidence of erosion on the rest of the site. 
CAU 400-Bomblet Pit - Plant cover on the Bomblet Pit CAU is lower than on any of the other sites, yet cover is higher than on the reference area. Plant cover in is just naturally lower than at the other sites. Cover is lower than previous years, but again this is probably a result of sampling time. Sampling time may also explain the lack of grasses; $100 \%$ of the cover was attributed to four different shrubs.

Plant density is still as good or better than most of the other sites. Shadscale and bud sagebrush were the most common shrubs and Indian ricegrass was the only grass encountered. Halogeton, a noxious weed that dominated the area before it was revegetated, is still present at the site, but density has decreased from 5.1 plants $/ \mathrm{m}^{2}$ in 1998 to just 0.1 plants $/ \mathrm{m}^{2}$ this year. This species is affected by the drought but can respond quickly to summer precipitation events.

There were no signs of herbivory or erosion. Plants are becoming established and with a year of sufficient moisture plants should increase in size and hopefully more grasses will become established. There continues to be a good diversity of native shrubs, and as with several other sites many plants have or are flowering and setting seed.

CAU 404-Rollercoaster Sewage Lagoons - This site is divided into two areas, the staging area around the cover cap and the cover cap. Plant cover and density remains high on the staging area. Shrubs account for over $90 \%$ of the total plant cover. There were more annuals this year than in past years, which was also the situation on the reference area. Again probably in response to precipitation received from summer thunderstorms. Total plant cover on the staging area exceeded plant cover on the reference area.

Plant density on the staging area was slightly less than plant density on the reference area. There were seven plants of shadscale for every plant of bud sagebrush on the staging area. On the reference area the relationship is just the opposite. There are about four plants of bud sagebrush for each plant of shadscale. Indian ricegrass was the most dominant grass on both the staging area and reference area, although there were about seven times as many plants on the reference area.

Plant cover on the cover cap is double what it is on the reference area. Unlike the reference area, where shrubs make up about $90 \%$ of the cover, shrubs and grasses contribute equally to overall plant cover. Cover estimates for the cover cap are higher than any of the other sites and is only slightly lower than estimates made last year.

Plant densities on the cover cap are almost double the density found on the reference area. There is a good mix of shrubs with shadscale being the most dominant. Galleta grass is the most dominant grass which has responded to the summer rains not only on the closure site but throughout the area (Figure 3). Plant densities at CAU 404-Rollercoaster are the highest of any of the closure sites. 
There are still a number of plants of shadscale that have dried and appear dead as was noted in June 2002. However, shadscale density is not any lower than it was in 2002, indicating that densities of shadscale are stabilizing and also suggests its resistance to drought conditions.

There are signs of erosion at this closure site, primarily at the base of the slopes on the southern edge of the cover cap (figure 4). It appears that during some of the summer thunderstorms the flow

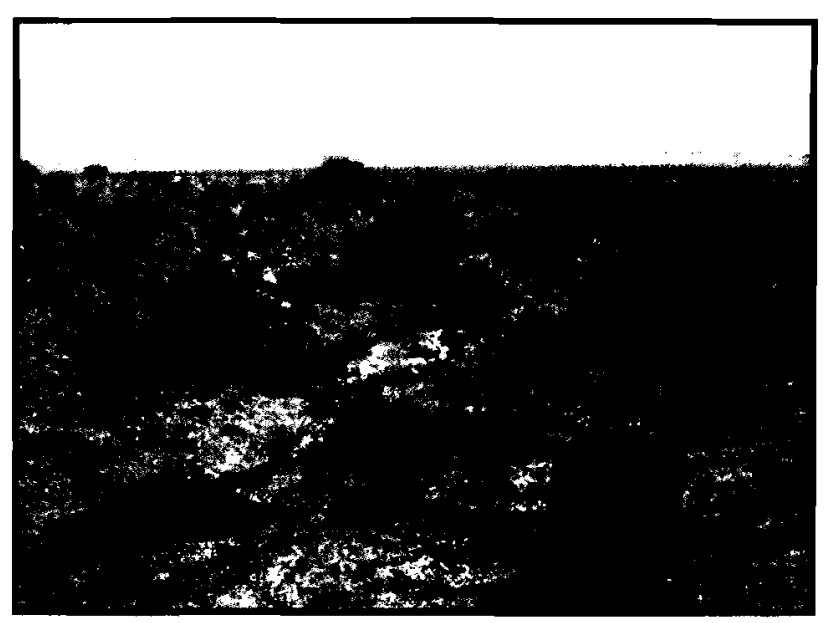

Figure 4. Erosion channel along southern edge of CAU 404-cover cap, fall 2003

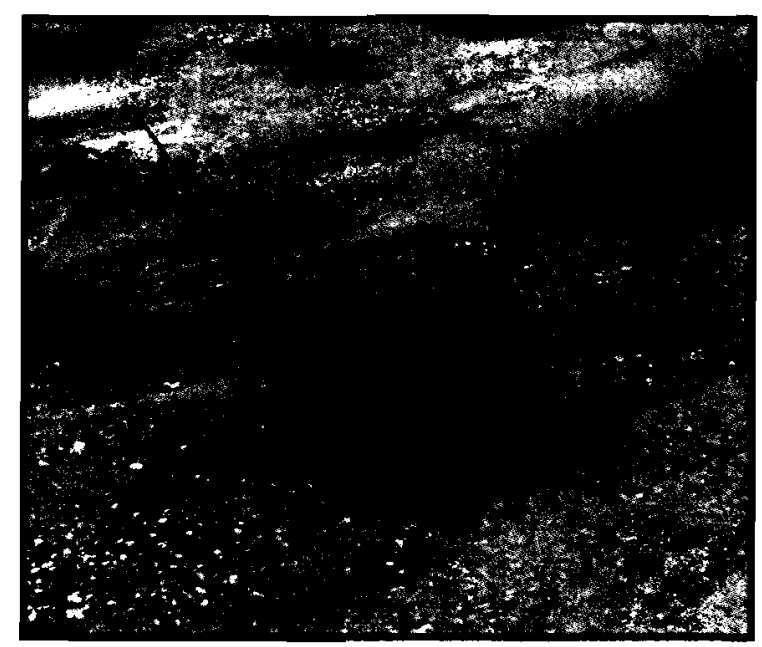

Figure 3. Galleta grass responded to summer rains and was abundant on the cover cap at CAU 404 and surrounding areas.

of water is down the road to the site, then onto the site and around the southern edge of the cover cap, which has caused some channeling. The noxious weed, halogeton is present on the site, but not as numerous as on the reference sit. Overall conditions of the vegetative cover at this site are still good. There is still a good diversity of native shrubs and grasses and plant cover is high.

\section{CAU 426-Cactus Springs Waste Trenches - CAU 426, like CAU 404-Rollercoaster, is} comprised of two areas, the staging area and the cover cap. On the staging area cover was a little higher than on the reference area. Unlike other closure sites and the adjacent reference area almost $50 \%$ of the cover was made up of grasses.

The density of the four species of shrubs seeded onto the staging area has decreased over the last year as has the density of an important grass, bottlebrush squirreltail. Bottlebrush squirreltail grows and flowers in the spring, early summer so by September it has dried and is difficult to detect. Consequently numbers reported are probably underestimates.

The density of halogeton is more abundant here than at any other closure site. It accounted for over one-third of the cover and about half of the total number of plants encountered on the staging area.

Plant cover on the cover cap at the Cactus Springs waste trenches is maintaining at about $17 \%$, about $4 \%$ higher than the reference area. About $90 \%$ of the cover is made up of shrubs, which is different from previous years where there was an equal contribution from shrubs and grasses. Again the timing of the sampling and the continued effects of the drought may have left many of the grasses dormant or dead. 
Density estimates suggest that shrubs and grasses are equally represented but overall numbers are lower than the reference area. Based on cover estimates the shrubs that are present are increasing in size, possibly at the expense of the grasses because the amount of cover from grasses has declined. The ratio of shrubs to grasses this year is more in line with the shrub to grass ratio on the reference area. Winterfat, a common shrub, is no longer found on the cover cap and the densities for bud sagebrush and fourwing saltbush have declined from previous years' densities. As noted previously the loss or decline in density of these species may have been the result of herbivory because these species are commonly preferred by rabbits and some small mammals.

There were no signs of erosion on the cover cap or the staging area. Overall conditions of the vegetative cover at this site are encouraging. Plant densities are low. However, those plants that have survived appear to be growing as indicated by higher plant cover.

CAU 407-Rollercoater RADSAFE Area - No sampling was necessary at this site. In previous years a few plants were observed, mainly shadscale. However this year there are no plants on the surface of the cover (Figure 5). There are a few annuals, Russian thistle and halogeton, around the edges and slopes of the cover, but they are not abundant.

Erosion may be a significant concern in the future. There is severe rilling off the slopes of the cover (Figure 5) possibly as a result of heavy summer rains in the area or maybe just from normal precipitation received earlier in the year.

Regardless of the cause gullies, some of them 610 " deep, are found around the entire circumference of the cover. Animal burrows previously noted at this site are still present although recent activity could not be determined.

\section{Summary/Discussion}

Plant cover for four closure sites exceeds cover

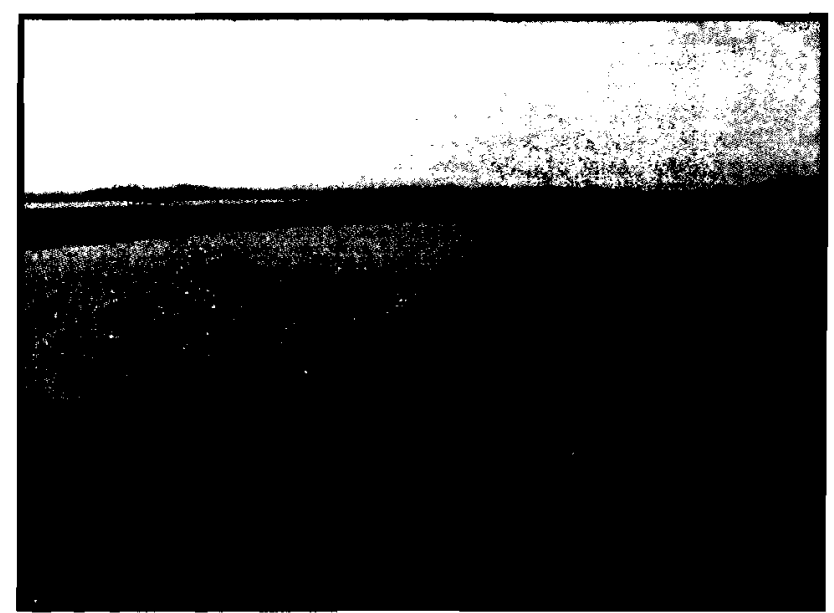

Figure 5. Erosion gullies along northern edge of cover at CAU 407 , fall 2003 estimates for their corresponding reference area. There is essentially no plant cover at CAU 407-

Rollercoaster RADSAFE area. Cover estimates made this year are overall lower than in 2002 (Figure 6). However, estimates this year were made in September well beyond the typical period of growth for most plant species in this region. Most grasses and forbs are now dormant and annual plants that may have been present earlier in the year are gone. Growing conditions were still not optimal as the drought in the southwestern United States continues. Even under these circumstances plant cover has not declined to levels that would cause concern. Plant cover continues above $20 \%$ on the cover cap 


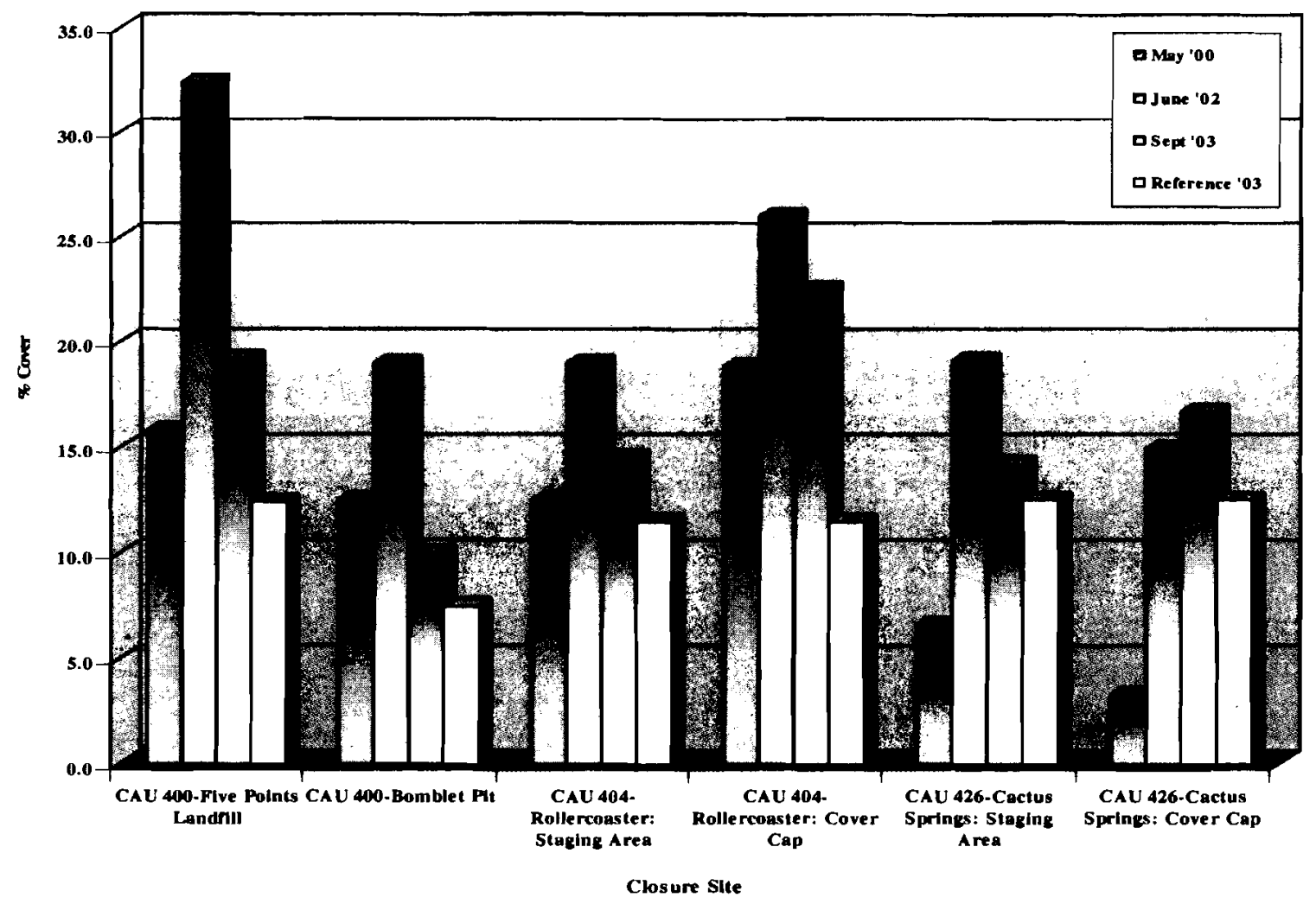

Figure 6. Plant cover on Tonopah Test Range closure sites from May 2000 to September 2003

at CAU 404-Rollercoaster and just below $20 \%$ at CAU 400-Five Points Landfill. It is around $15 \%$ at CAU 404-Rollercoaster staging area and the two sites at CAU 426-Cactus Springs. Only at CAU 400-Bomblet Pit does cover drop below 10\%. However the reference area has only $7 \%$ plant cover.

Plant density, of species included in the seed mix used to revegetate the closure sites, have all maintained at a level equal to or higher that plant densities for respective reference areas. Only at the CAU 426-Cactus Springs Waste Trenches were plant densities lower than on the reference area (Figure 7). Plant densities remain high at the CAU 404-Rollercoaster cover cap with over 12 plants $/ \mathrm{m}^{2}$. At CAU 400-Bomblet Pit plant density was about 10 plants $/ \mathrm{m}^{2}$ and plant densities at the other sites were 5 or less plants $/ \mathrm{m}^{2}$. The only plants at CAU 407-Rollercoaster RADSAFE site were annual weeds, primarily halogeton and Russian thistle. The site has obviously been disturbed since it was reseeded in 2000. Any plants that may have established from the original seeding have not survived the impact of new disturbances, nor the last three years of drought. 


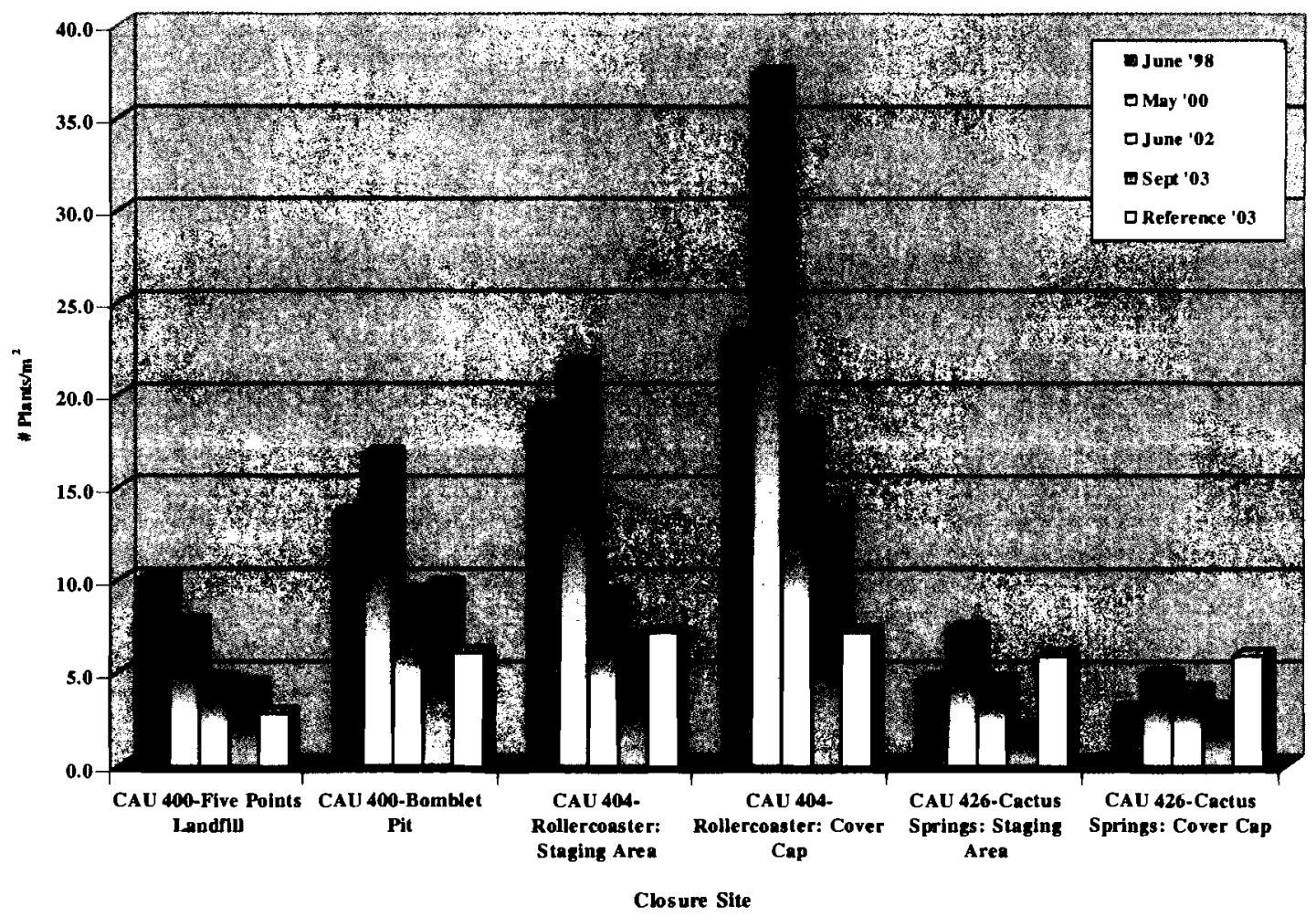

Figure 7. Perennial plant density on Tonopah Test Range Closure Sites from June 1998 to September 2003.

\section{Concerns/Recommendations}

The major concern noted this fall was standing water at CAU 400-Five Points Landfill. About half of the area was or has been under water. Some plants that had been submerged, although now above the standing water are covered with a layer of sediment that will probably reduce its photosynthetic capability and may eventually result in the death of the plants. Vegetation may eventually re-establish on the site but natural processes may take decades. The site will continue to be vulnerable to standing water because a couple stream channels funnel into the area and there is no outlet. If standing water does not compromise the integrity of the landfill no remedial action would be necessary. The area of water accumulation could be seeded but even under normal precipitation the area may become a collection basin and make plant establishment difficult. If remedial action is necessary, it would take a major effort to modify the site so surface waters would flow through the site and into downstream channels. The basin on the west end of the site would have to be brought up to grade and a culvert would have to be constructed under the road so water could flow off the site.

The perimeter fence at the site during the September 2003 monitoring event is depicted on Figure 8. Where the fence crosses the channel about 10-15 feet of the fence has been partially covered with sediment. The need to repair the fence is uncertain. The vegetation on the site appears to be well established. However, if there is going to be any remedial work, i.e., reseeding, or recontouring, etc., it would be advantageous to repair the fence. 
The original concern at CAU 400-Bomblet Pit was the invasion of noxious weeds, primarily halogeton, a plant that dominated the area prior to closure. The density of halogeton has declined since revegetation occurred and there does not appear to be a problem.

An area of concern that surfaced last year and continued this year was the loss of grass species. In 2001 there were about five grasses $/ \mathrm{m}^{2}$. In 2002 that number dropped to 0.15 plants $/ \mathrm{m}^{2}$ and this year is was 0.40 plants $/ \mathrm{m}^{2}$. If this trend continues under more normal precipitation patterns it may be advantageous to seed the area with a mix of native grasses. If remedial action does become necessary it would be advantageous to have the fence in place to enhance the potential for the re-establishment of grasses.

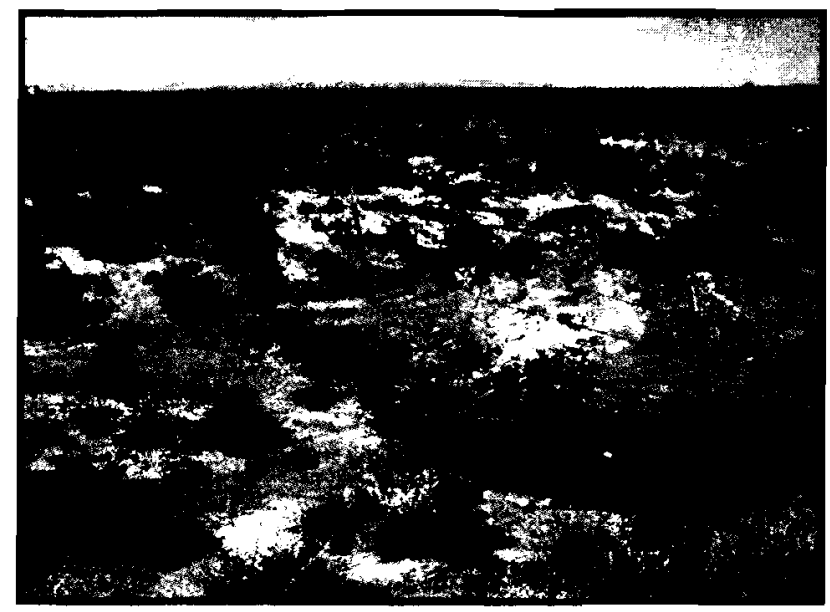

Figure 8. Fence along eastern edge of CAU 400-Five Points Landfill during late summer of 2003.

Surface erosion at CAU 404-Rollercoaster staging area was evident previously. However, this year is was more noticeable. As mentioned the road to the site seems to channel surface waters onto the site. This year there was sufficient precipitation so that overland flow reached the base of the cover cap and some channeling occurred along the southern edge. If channeling continues, which is likely, the integrity of the cover cap could be compromised. Diversion ditches placed north and down slope of the cover cap during closure activities are effective in diverting the water off the site and into natural drainages. Similar diversion ditches could be placed up slope from the cover cap and divert overland flows of water away from the cover cap and into natural drainages. The vegetation is establishing well on both the staging area and the cover cap, but because of the geographic position of the site, i.e., down slope, erosion is a concern.

There are two related concerns at the CAU 407-Rollercoaster RADSAFE site, lack of vegetative cover and erosion. The cover is completely void of vegetation which in turn has resulted in increased runoff and numerous gullies around the perimeter of the cover. Some remedial action might be appropriate at this site. The establishment of vegetation on the cover would reduce the potential for erosion or diversion channels could be used to direct water flow and possibly reduce the number of gullies that are forming on the cover.

CAU 426-Cactus Springs staging area has the highest density of halogeton of any of the closure sites. Halogeton is common on the TTR and grows especially well on disturbed soils. Densities at CAU 426 were especially high in 2000, decreased in 2002 and have increased slightly this year. This site should be closely monitored and remedial action taken as is necessary to ensure the establishment of native plant species and control of halogeton and other noxious weeds. 
On the cover cap at CAU 426-Cactus Springs plant densities continue to be lower than densities on the reference area, but it is not a major concern. Although plant density is low, plant cover is high indicating that even though there are not very many plants present, those that are present are well established and contribute to a good vegetative cover. The only recommendation would be to monitor the site to ensure that plant density does not decrease to critically low levels and that plant cover remains high. 
APPENDIX A

Plant Cover and Density Data 
THIS PAGE INTENTIONALLY LEFT BLANK 


\section{Plant Density}

Shrubs Artemisia spinescens

Atriplex canescens

Chrysothamnus greenei

Krascheninnikovia lanata

Grasses Elymus elymoides

Pleuraphus jamesii

Acnatherum hymenoides

Forbs Sphaeralcea ambigua

Total Seeded

\# Species

Total Non-Seeded

\# Species

\section{Plant Cover}

Shrub

Grass

Perennial Forbs

Annuals

Total Plant Cover

Bare

Rock/Gravel/Cobble

Litter/Mulch
CAU 400-Five Points Landfill

Revegetation Success Monitoring

September 2003

\begin{tabular}{|c|c|c|c|c|}
\hline $\begin{array}{c}\text { Jun-98 } \\
\left.\text { (\#Plants } / \mathrm{m}^{2}\right)\end{array}$ & $\begin{array}{c}\text { May-00 } \\
\left.\text { \# Plants } / \mathrm{m}^{2}\right)\end{array}$ & $\begin{array}{c}\text { Jun-02 } \\
\left.\text { (\# Plants } / \mathrm{m}^{2}\right)\end{array}$ & $\begin{array}{c}\text { Sept-03 } \\
\text { (\# Plants } / \mathrm{m}^{2} \text { ) }\end{array}$ & $\begin{array}{c}\text { Ref '03 } \\
\left.\text { (\# Plants } / \mathrm{m}^{2}\right)\end{array}$ \\
\hline 0.1 & 0.0 & 0.1 & 0.1 & 0.0 \\
\hline \multirow[t]{2}{*}{2.6} & 0.7 & 1.0 & 1.4 & 0.1 \\
\hline & $\begin{array}{l}\text { Not in seed } \\
\text { mix }\end{array}$ & & & 0.9 \\
\hline 0.0 & 0.0 & 0.0 & 0.0 & 0.0 \\
\hline 3.6 . & 2.2 & 0.3 & 0.8 & 0.0 \\
\hline 0.0 & 0.0 & 0.0 & 0.0 & 0.0 \\
\hline 3.8 & 4.8 & 3.2 & 2.1 & 1.8 \\
\hline 0.0 & 0.0 & 0.0 & 0.0 & 0.0 \\
\hline 10.1 & 7.7 & 4.7 & 4.4 & 2.8 \\
\hline 4.0 & 4.0 & 6.0 & 4.0 & 3.0 \\
\hline 0.0 & 10.2 & 0.4 & 1.3 & 1.5 \\
\hline \multirow[t]{10}{*}{0.0} & 10.0 & 4.0 & 2.0 & 5.0 \\
\hline & 2000 & 2002 & $\underline{2003}$ & $\underline{\operatorname{Ref}{ }^{\prime} 03}$ \\
\hline & 2.5 & 8.3 & 9.2 & 5.8 \\
\hline & 13.3 & 23.3 & 10.0 & 5.8 \\
\hline & 0.0 & 0.0 & 0.0 & 0 \\
\hline & 0.0 & 0.8 & 0.0 & 0.8 \\
\hline & 15.8 & 32.4 & 19.2 & 12.4 \\
\hline & 43.3 & 49.2 & 47.5 & 70.8 \\
\hline & 23.3 & 0.8 & 10.0 & 1.7 \\
\hline & 17.5 & 17.5 & 23.3 & 15 \\
\hline
\end{tabular}

Stable

Stable
Critical
Stable

Stable

Erosion Classification 
CAU 400-Bomblet Pit

Revegetation Success Monitoring

September 2003

Plant Density

Shrubs Artemisia spinescens

Atriplex canescens

Atriplex confertifolia

Krascheninnikovia lanata

Grasses Elymus elymoides

Pleuraphus jamesii

Acnatherum hymenoides

Forbs Sphaeralcea ambigua

Total Seeded

\# Species

Total Non-Seeded

\# Species

\section{Plant Cover}

Shrub

Grass

Perennial Forbs

Annuals

Total Plant Cover

Bare

Rock/Gravel/Cobble

Litter/Mulch

\begin{tabular}{ccccc}
$\begin{array}{c}\text { Jun-98 } \\
\left.\text { \#Plants } / \mathrm{m}^{2}\right)\end{array}$ & $\begin{array}{c}\text { May-00 } \\
\left.\text { \#Plants } / \mathrm{m}^{2}\right)\end{array}$ & $\begin{array}{c}\text { Jun-02 } \\
\left.\text { (\#Plants } / \mathrm{m}^{2}\right)\end{array}$ & $\begin{array}{c}\text { Sept-03 } \\
\left.\text { (\#Plants } / \mathrm{m}^{2}\right)\end{array}$ & $\begin{array}{c}\text { Ref '03 } \\
\text { \#Plants } / \mathrm{m}^{2}\end{array}$ \\
\hline 1.2 & 3.8 & 2.5 & 2.6 & 4.0 \\
0.1 & 0.5 & 0.3 & 0.2 & 0.0 \\
5.3 & 6.8 & 6.5 & 6.4 & 1.5 \\
0.0 & 0.3 & 0.0 & 0.1 & 0.1 \\
4.4 & 3.1 & 0.0 & 0.0 & 0.0 \\
0.3 & 0.0 & 0.0 & 0.0 & 0.2 \\
2.3 & 2.5 & 0.2 & 0.4 & 0.3 \\
0.0 & 0.0 & 0.0 & 0.0 & 0.0 \\
13.6 & 16.9 & 9.4 & 9.7 & 6.1 \\
6.0 & 6.0 & 4.0 & 5.0 & 5.0 \\
5.2 & 3.3 & & & \\
2.0 & 5.0 & 1.0 & 0.0 & 0.0 \\
& & & 1.0 & 0.0
\end{tabular}

$2000 \quad 2002 \quad 2003$

12.5

19.0

10.0

0.0

0.0

0.0

10.0

$\underline{\text { Ref ' } 03}$

6.2

0.0
0.0

0.0

0.0

19.0

53.8

20.0

16.3

1.3

0.0

0.0

7.5

42.5

35.0

26.0

20.0

23.8

57.5

12.5

Stable

Stable

Stable

Stable 
Plant Density

Shrubs Artemisia spinescens

Atriplex canescens

Atriplex confertifolia

Krascheninnikovia lanata

Grasses Elymus elymoides

Pleuraphus jamesii

Acnatherum hymenoides

Forbs Sphaeralcea ambigua

Total Seeded

\# Species

Total Non-Seeded

\# Species

Plant Cover

Shrub

Grass

Perennial Forbs

Annuals

Total Plant Cover

Bare

Rock/Gravel/Cobble

Litter/Mulch
Jun-98
(\#Plants $\left./ \mathrm{m}^{2}\right)$

1.7

0.2

6.7

0.2

7.7

0.0

2.5

0.1

19.1

7.0

2.3

3.0
CAU 404-Rollercoaster Staging Area

Revegetation Success Monitoring

September 2003

\begin{tabular}{cccc}
$\begin{array}{c}\text { May-00 } \\
\text { \#Plants } / \mathrm{m}^{2} \text { ) }\end{array}$ & $\begin{array}{c}\text { Jun-02 } \\
\text { (\#Plants } / \mathrm{m}^{2} \text { ) }\end{array}$ & $\begin{array}{c}\text { Sept-03 } \\
\text { (\#Plants } / \mathrm{m}^{2} \text { ) }\end{array}$ & $\begin{array}{c}\text { Ref '03 } \\
\text { (\#Plants } / \mathrm{m}^{2} \text { ) }\end{array}$ \\
\hline 1.7 & 1.2 & 0.8 & 3.8 \\
0.3 & 0.2 & 0.1 & 0.0 \\
10.0 & 6.9 & 5.5 & 1.1 \\
0.0 & 0.1 & 0.1 & 0.1 \\
6.2 & 0.1 & 0.0 & 0.0 \\
0.8 & 0.3 & 0.2 & 1.5 \\
2.5 & 0.5 & 0.0 & 0.2 \\
0.1 & 0.0 & 0.0 & 0.6 \\
21.6 & 9.2 & 6.8 & 7.2 \\
8.0 & 7.0 & 7.0 & 6.0 \\
3.4 & 0.8 & 0.7 & 1.3 \\
4.0 & 6.0 & 1.0 & 3.0
\end{tabular}

$\underline{2000}$

9.0

3.5

0.0

0.0

12.5

37.5

19.0

31.0

Moderate Stable $\underline{2002} \quad \underline{2003}$

$18.5 \quad 13.5$

$0.5 \quad 0.5$

$0.0 \quad 0.0$

$0.0 \quad 0.5$

19.0

45.0

8.0

28.0

Slight

64.0

5.0

16.5
Ref 03

9.5

1.5

0.0

0.5

11.5

34

41.5

13

\section{Erosion Classification}




\section{Plant Density}

Shrubs Artemisia spinescens

Atriplex canescens

Atriplex confertifolia

Krascheninnikovia lanata

Grasses Elymus elymoides

Pleuraphus jamesii

Acnatherum hymenoides

Forbs Sphaeralcea ambigua

Total Seeded

\# Species

Total Non-Seeded

\# Species

\section{Plant Cover}

Shrub

Grass

Perennial Forbs

Annuals

Total Plant Cover

Bare

Rock/Gravel/Cobble

Litter/Mulch

J P

CAU 404-Rollercoaster Cover Cap Revegetation Success Monitoring September 2003

$\begin{array}{ccccc}\begin{array}{c}\text { Jun-98 } \\ \text { \#Plants } / \mathrm{m}^{2} \text { ) }\end{array} & \begin{array}{c}\text { May-00 } \\ \left.\text { (\#Plants } / \mathrm{m}^{2}\right)\end{array} & \begin{array}{c}\text { Jun-02 } \\ \left.\text { (\#Plants } / \mathrm{m}^{2}\right)\end{array} & \begin{array}{c}\text { Sept-03 } \\ \left.\text { (\#Plants } / \mathrm{m}^{2}\right)\end{array} & \begin{array}{c}\text { Ref '03 } \\ \left.\text { (\#Plants } / \mathrm{m}^{2}\right)\end{array} \\ 0.9 & 2.1 & 1.7 & 0.0 & 3.8 \\ 13.5 & 0.9 & 0.6 & 0.3 & 0.0 \\ 0.3 & 10.9 & 7.0 & 7.0 & 1.1 \\ 6.6 & 0.3 & 0.1 & 0.0 & 0.1 \\ 0.0 & 10.8 & 1.6 & 0.1 & 0.0 \\ 0.0 & 8.6 & 4.7 & 4.9 & 1.5 \\ 0.0 & 3.8 & 2.8 & 1.1 & 0.2 \\ 23.1 & 0.2 & 0.1 & 0.1 & 0.6 \\ 5.0 & 37.5 & 18.4 & 13.5 & 7.2 \\ & 8.0 & 8.0 & 7.0 & 6.0 \\ 0.4 & 0.3 & 0.2 & 0.1 & 1.3 \\ 2.0 & 2.0 & 2.0 & 1.0 & 3.0 \\ & & & & \\ & 2000 & 2002 & \underline{2003} & \underline{\text { Ref } 03} \\ & 6.3 & 10.0 & 12.5 & 9.5 \\ & 12.5 & 16.0 & 10.1 & 1.5 \\ & 0.0 & 0.0 & 0.0 & 0.0 \\ & 0.0 & 0.0 & 0.0 & 0.5 \\ & 18.8 & 26.0 & 22.5 & 11.5 \\ & & & & 34 \\ & 22.5 & 50.0 & 61.3 & 41.5 \\ & 51.3 & 15.0 & 10.0 & 13\end{array}$

Erosion Classification

Stable

Moderate 


\section{Plant Density}

Shrubs Artemisia nova

Atriplex canescens

Atriplex confertifolia

Ephedra nevadensis

Ericameria nauseosa

Krascheninnikovia lanata

Sarcobatus vermiculatus

Grasses Elymus elymoides

Pleuraphus jamesii

Acnatherum hymenoides

Forbs Sphaeralcea ambigua

Total Seeded

\# Species

Total Non-Seeded

\# Species

Plant Cover

Shrub

Grass

Perennial Forbs

Annuals

Total Plant Cover

Bare

Rock/Gravel/Cobble

Litter/Mulch

$$
\text { Jun-98 }
$$

(\#Plants $/ \mathrm{m}^{2}$ )

0.0

0.1

0.1

0.0

0.3

0.0

0.0

3.1

0.0

1.0

0.0

4.6

5.0

3.2

1

Revetation Success Monitoring

September 2003

\begin{tabular}{|c|c|c|c|c|}
\hline $\begin{array}{c}\text { Jun-98 } \\
\text { (\#Plants / } \mathrm{m}^{2} \text { ) }\end{array}$ & $\begin{array}{c}\text { May-00 } \\
\left.\text { (\#Plants } / \mathrm{m}^{2}\right)\end{array}$ & $\begin{array}{c}\text { Jun-02 } \\
\left.\text { (\#Plants } / \mathrm{m}^{2}\right)\end{array}$ & $\begin{array}{c}\text { Sept-03 } \\
\left.\text { (\# Plants } / \mathrm{m}^{2}\right)\end{array}$ & $\begin{array}{c}\text { Ref } 03 \\
\left.\text { (\# Plants } / \mathrm{m}^{2}\right)\end{array}$ \\
\hline 0.0 & 0.0 & 0.1 & 0.0 & 0.6 \\
\hline 0.1 & 0.1 & 0.0 & 0.0 & 0.0 \\
\hline 0.1 & 0.1 & 0.0 & 0.0 & 0.1 \\
\hline 0.0 & 0.3 & 0.2 & 0.3 & 0.0 \\
\hline 0.3 & 0.1 & 0.8 & 0.1 & 0.0 \\
\hline 0.0 & 0.0 & 0.0 & 0.0 & 0.0 \\
\hline 0.0 & 0.0 & 0.0 & 0.0 & 0.1 \\
\hline 3.1 & 5.2 & 2.9 & 0.6 & 0.1 \\
\hline 0.0 & 0.2 & 0.1 & 0.3 & 4.9 \\
\hline 1.0 & 1.4 & 0.6 & 0.7 & 0.0 \\
\hline 0.0 & 0.0 & 0.0 & 0.0 & 0.1 \\
\hline 4.6 & 7.4 & 4.6 & 2.0 & 6.0 \\
\hline 5.0 & 9.0 & 7.0 & 7.0 & 9.0 \\
\hline 3.2 & 17.0 & 1.8 & 4.0 & 0.4 \\
\hline 1 & 6 & 5 & 3 & 3 \\
\hline & $\underline{2000}$ & $\underline{2002}$ & $\underline{2003}$ & $\underline{\text { Ref } 03}$ \\
\hline & 0.8 & 5.0 & 2.5 & 10.8 \\
\hline & 5.8 & 12.5 & 6.7 & 1.7 \\
\hline & 0.0 & 0.0 & 0.0 & 0.0 \\
\hline & 0.0 & 1.6 & 5.0 & 0.0 \\
\hline & 6.6 & 19.1 & 14.2 & 12.5 \\
\hline & 29.2 & 40.8 & 46.7 & 26.7 \\
\hline & 20.8 & 1.7 & 3.3 & 47.5 \\
\hline & 43.3 & 38.3 & 35.8 & 13.3 \\
\hline Stable & Stable & Stable & Stable & \\
\hline
\end{tabular}

\section{Erosion Classification}


Plant Density

Shrubs Artemisia nova

Atriplex canescens

Atriplex confertifolia

Ephedra nevadensis

Ericameria nauseosa

Krascheninnikovia lanata

Sarcobatus vermiculatus

Grasses Elymus elymoides

Pleuraphus jamesii

Acnatherum hymenoides

Forbs Sphaeralcea ambigua

Total Seeded

\# Species

Total Non-Seeded

\# Species

Plant Cover

Shrub

Grass

Perennial Forbs

Annuals

Total Plant Cover

Bare

Rock/Gravel/Cobble

Litter/Mulch

Erosion Classification
CAU 426-Cactus Springs Cover Cap

Revegetation Success Monitoring

September 2003

\begin{tabular}{|c|c|c|c|c|}
\hline $\begin{array}{c}\text { Jun-98 } \\
\left.\text { (\#Plants } / \mathrm{m}^{2}\right)\end{array}$ & $\begin{array}{c}\text { May-00 } \\
\left.\text { \# Plants } / \mathrm{m}^{2}\right)\end{array}$ & $\begin{array}{c}\text { Jun-02 } \\
\left.\text { (\# Plants } / \mathrm{m}^{2}\right)\end{array}$ & $\begin{array}{c}\text { Sept-03 } \\
\left.\text { (\#Plants } / \mathrm{m}^{2}\right)\end{array}$ & $\begin{array}{c}\text { Ref '03 } \\
\text { \# Plants } / \mathrm{m}^{2}\end{array}$ \\
\hline 0.0 & 0.0 & 0.0 & 0.0 & 0.6 \\
\hline 0.2 & 0.0 & 0.0 & 0.0 & 0.0 \\
\hline 0.3 & 0.0 & 0.0 & 0.0 & 0.1 \\
\hline 0.0 & 1.0 & 1.3 & 1.3 & 0.0 \\
\hline 0.4 & 0.1 & 1.1 & 0.5 & 0.0 \\
\hline 0.0 & 0.1 & 0.0 & 0.0 & 0.0 \\
\hline 0.1 & 0.1 & 0.0 & 0.0 & 0.1 \\
\hline 0.9 & 1.0 & 0.2 & 0.3 & 0.1 \\
\hline 0.0 & 1.4 & 0.7 & 0.4 & 4.9 \\
\hline 1.1 & 1.3 & 0.7 & 0.6 & 0.0 \\
\hline 0.0 & 0.0 & 0.0 & 0.0 & 0.1 \\
\hline 3.0 & 4.9 & 4.1 & 3.1 & 6.0 \\
\hline 7.0 & 8.0 & 6.0 & 6.0 & 10.0 \\
\hline 6.8 & 0.1 & 0.1 & 0.4 & 0.4 \\
\hline \multirow[t]{10}{*}{3.0} & 2.0 & 1.0 & 3.0 & 3.0 \\
\hline & $\underline{2000}$ & $\underline{2002}$ & $\underline{2003}$ & $\underline{\operatorname{Ref}}$ '03 \\
\hline & 0.0 & 6.6 & 16.7 & 10.8 \\
\hline & 3.3 & 8.3 & 0.0 & 1.7 \\
\hline & 0.0 & 0.0 & 0.0 & 0.0 \\
\hline & 0.0 & 0.0 & 0.0 & 0.0 \\
\hline & 3.3 & 14.9 & 16.7 & 12.5 \\
\hline & 10.0 & 73.3 & 75.0 & 26.7 \\
\hline & 75.0 & 5.0 & 5.0 & 47.5 \\
\hline & 11.7 & 6.7 & 3.3 & 13.3 \\
\hline
\end{tabular}

Stable $\quad$ Stable $\quad$ Stable $\quad$ Stable 
APPENDIX B

Post Closure Monitoring Checklists 
THIS PAGE INTENTIONALLY LEFT BLANK 


\section{CAU 400: FIVE POINTS LANDFILL, POST-CLOSURE MONITORING CHECKLIST}

\begin{tabular}{|l|l|}
\hline \hline Date of Last Inspection: June 3,2002 & Reason for Last Inspection: Annual Monitoring \\
\hline Responsible Agency: Bechtel Nevada & Project Manager: R. Jackson \\
\hline Inspection Date: September 8, 2003 & \\
\hline Inspector (name, title, organization): David C. Anderson, Scientist, Bechtel Nevada \\
\hline Assistant Inspector (name, title, organization): W. Kent Ostler, Scientist, Bechtel Nevada \\
\hline \hline
\end{tabular}

\section{A. GENERAL INSTRUCTIONS}

1. All checklist items must be completed and detailed comments made to document the results of the site inspection. The completed checklist is part of the field record of the inspection. Additional pages should be used as necessary to ensure that a complete record is made. Attach the additional pages and number all pages upon completion of the inspection.

3. Any checklist line item marked by an inspector in a SHADED BOX, must be fully explained or an appropriate reference to previous reports provided. The purpose of this requirement is to provide a written explanation of inspector observations and the inspector's rationale for conclusions and recommendations. Explanations are to be placed on additional attachments and cross-referenced appropriately. Explanations, in addition to narrative, will take the form of sketches, measurements, annotated site maps.

4. The site inspection is a walking inspection of the entire site including the perimeter and sufficient transects to be able to inspect the entire surface and all features specifically described in this checklist.

5. A standard set of color $35 \mathrm{~mm}$ photographs is required. In addition, all anomalous features or new features (such as changes in adjacent area land use) are to be photographed. A photo log entry will be made for each photograph taken.

6. This unit will be inspected biannually with formal reporting to the Nevada Division of Environmental Protection to be done annually. The annual report will include an executive summary, this inspection checklist with field notes and photo log attached, and recommendations and conclusions.

\begin{tabular}{|c|c|c|c|}
\hline B. PREPARATION (To be completed prior to site visit) & YES & NO & EXPLANATION \\
\hline 1. Site as-built plans and site base map reviewed. & & & \\
\hline \multicolumn{4}{|l|}{ 2. Previous inspection reports reviewed. } \\
\hline a. Were anomalies or trends detected on previous inspections? & & & \\
\hline b. Was maintenance performed? & & & \\
\hline \multicolumn{4}{|l|}{ 3. Site maintenance and repair records reviewed. } \\
\hline a. Has site repair resulted in a change from as-built conditions? & & & \\
\hline b. Are revised as-builts available that reflect repair changes? & & & \\
\hline C. SITE INSPECTION (To be completed during inspection) & YES & NO & EXPLANATION \\
\hline
\end{tabular}

1. Adjacent off-site features within watershed areas.

a. Have there been any changes in use of adjacent area?

b. Are there any new roads or trails?

c. Has there been a change in the position of nearby washes?

d. Has there been lateral excursion or erosion/deposition of nearby washes?

e. Are there new drainage channels?

f. Change in surrounding vegetation?

2. Security fence, signs.

a. Displacement of fences, site markers, boundary markers, or monuments?

b. Have any signs been damaged or removed?

(Number of signs replaced: )

c. Were gates locked?

\begin{tabular}{|c|c|l|}
\hline & $\mathbf{X}$ & \\
\hline & $\mathbf{X}$ & \\
\hline $\mathbf{X}$ & & Recent standing water on site \\
\hline $\mathbf{X}$ & & $\begin{array}{l}\text { Water entered site via channel from east side } \\
\text { of site }\end{array}$ \\
\hline & $\mathbf{X}$ & \\
\hline & $\mathbf{X}$ & \\
\hline
\end{tabular}

\begin{tabular}{|c|c|l|}
\hline $\mathbf{X}$ & & Debris against east fence line \\
\hline & $\mathbf{X}$ & \\
\hline $\mathbf{X}$ & & Gate shut, no lock present \\
\hline
\end{tabular}




\section{CAU 400: FIVE POINTS LANDFILL, POST-CLOSURE MONITORING CHECKLIST}

3. Waste Unit cover.

a. Is there evidence of settling?

b. Is there cracking?

c. Is there evidence of erosion around the cap (wind or water)?

d. Is there evidence of animal burrowing?

e. Have the site markers been disturbed by man or natural processes?

f. Do natural processes threaten to integrity of any cover or site marker?

g. Other?

\begin{tabular}{|l|l|l|}
\multicolumn{1}{l|}{ YES } & \multicolumn{1}{l}{ NO } & EXPLANATION \\
\hline & $\mathbf{X}$ & \\
\hline $\mathbf{X}$ & & Sediment from standing water was cracking \\
\hline & $\mathbf{X}$ & \\
\hline $\mathbf{X}$ & & Mainly in se comer of site \\
\hline & $\mathbf{X}$ & \\
\hline & $\mathbf{X}$ & \\
& & \\
\hline & & \\
\hline
\end{tabular}

4. Vegetative cover.

a. Is perimeter fence or mesh fencing damaged?

b. Is there evidence of horses or rabbits on site?

c. Is organic mulch adequate to prevent erosion?

d. Are weedy annual plants present? If yes, are they a problem?

e. Are seeded plant species found on site?

f. Is there evidence of plant mortality?

\begin{tabular}{|c|c|c|}
\hline$\overline{\mathbf{X}}$ & & $\begin{array}{l}\text { East fence has accumulated sediment and } \\
\text { debris }\end{array}$ \\
\hline & $\mathbf{X}$ & \\
\hline $\mathbf{X}$ & & \\
\hline $\bar{X}$ & & $\begin{array}{l}\text { Russian thistle, but doesn't appear to be a } \\
\text { problem }\end{array}$ \\
\hline $\mathbf{X}$ & & See attached report \\
\hline $\bar{X}$ & & $\begin{array}{l}\text { Where water ponded on west end of site } \\
\text { plants are either submerged or covered with } \\
\text { mud }\end{array}$ \\
\hline
\end{tabular}

5. Photo Documentation

a. Has a photo $\log$ been prepared?

c. Number of photos exposed (Three, attached to report)

\begin{tabular}{|l|l|l|}
\hline $\mathbf{X}$ & & See attached report \\
\hline
\end{tabular}

\section{FIELD CONCLUSIONS}

1. Is there an imminent hazard to the integrity of the unit? (Immediate report required) Person/Agency to whom report made: verbal to Andrew Lacey

2. Are more frequent inspections required?

3. Are existing maintenance/repair actions satisfactory?

4. Is other maintenance/repair necessary?

5. Is current status/condition of vegetative cover satisfactory?

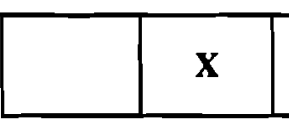

$\mathbf{X}$

6. Rationale for field conclusions: Observations, plant cover and density data

\section{E. CERTIFICATION}

I have conducted an inspection of the Five Points Landfill, at the TTR in accordance with the Post-Closure Monitoring Plan (see Closure Report) as recorded on this checklist, attached sheets, field notes, photo logs, and photographs.

Chief Inspector's Signature:

Printed Name: David C. Anderson

After water subsides or evaporates should inspect for settling

Plant where pond has formed are dead. When water is gone area will be void of plant cover 
CAU 400: BOMBLET PIT, POST-CLOSURE MONITORING CHECKLIST

Date of Last Inspection: June 3, 2002

Reason for Last Inspection: Annual Monitoring

Responsible Agency: Bechtel Nevada

Project Manager: R. Jackson

Inspection Date: September 8,2003

Inspector (name, title, organization): David C. Anderson, Scientist, Bechtel Nevada

Assistant Inspector (name, title, organization): W. Kent Ostler, Scientist, Bechtel Nevada

\section{A. GENERAL INSTRUCTIONS}

1. All checklist items must be completed and detailed comments made to document the results of the site inspection. The completed checklist is part of the field record of the inspection. Additional pages should be used as necessary to ensure that a complete record is made. Attach the additional pages and number all pages upon completion of the inspection.

3. Any checklist line item marked by an inspector in a SHADED BOX. must be fully explained or an appropriate reference to previous reports provided. The purpose of this requirement is to provide a written explanation of inspector observations and the inspector's rationale for conclusions and recommendations. Explanations are to be placed on additional attachments and cross-referenced appropriately. Explanations, in addition to narrative, will take the form of sketches, measurements, annotated site maps.

4. The site inspection is a walking inspection of the entire site including the perimeter and sufficient transects to be able to inspect the entire surface and all features specifically described in this checklist.

5. A standard set of color $35 \mathrm{~mm}$ photographs is required. In addition, all anomalous features or new features (such as changes in adjacent area land use) are to be photographed. A photo log entry will be made for each photograph taken.

6. This unit will be inspected biannually with formal reporting to the Nevada Division of Environmental Protection to be done annually. The annual report will include an executive summary, this inspection checklist with field notes and photo log attached, and recommendations and conclusions.

B. PREPARATION (To be completed prior to site visit)

1. Site as-built plans and site base map reviewed.

2. Previous inspection reports reviewed.

a. Were anomalies or trends detected on previous inspections?

b. Was maintenance performed?

3. Site maintenance and repair records reviewed.

a. Has site repair resulted in a change from as-built conditions?

b. Are revised as-builts available that reflect repair changes?

C. SITE INSPECTION (To be completed during inspection)

\begin{tabular}{|c|c|c|c|} 
& YES & NO & EXPLANATION \\
\hline
\end{tabular}

1. Adjacent off-site features within watershed areas.

a. Have there been any changes in use of adjacent area?

b. Are there any new roads or trails?

c. Has there been a change in the position of nearby washes?

d. Has there been lateral excursion or erosion/deposition of nearby washes?

e. Are there new drainage channels?

f. Change in surrounding vegetation?

\begin{tabular}{|l|c|l|}
\hline & $\mathbf{X}$ & \\
\hline & $\mathbf{X}$ & \\
\hline & $\mathbf{X}$ & \\
\hline & $\mathbf{X}$ & \\
\hline & $\mathbf{X}$ & \\
\hline & $\mathbf{X}$ & \\
\hline
\end{tabular}

2. Security fence, signs.

a. Displacement of fences, site markers, boundary markers, or monuments?

b. Have any signs been damaged or removed? (Number of signs replaced:

c. Were gates locked?

\begin{tabular}{|l|l|l|}
\hline & $\mathbf{X}$ & \\
\hline & $\mathbf{X}$ & \\
\hline $\mathbf{X}$ & & Gate was shut, there is no lock \\
\hline
\end{tabular}




\section{CAU 400: BOMBLET PIT, POST-CLOSURE MONITORING CHECKLIST}

3. Waste Unit cover.
a. Is there evidence of settling?
b. Is there cracking?
c. Is there evidence of erosion around the cap (wind or water)?
d. Is there evidence of animal burrowing?
e. Have the site markers been disturbed by man or natural processes?
f. Do natural processes threaten to integrity of any cover or site marker?
g. Other?

\begin{tabular}{|l|l|l|}
\multicolumn{1}{c}{ YES } & \multicolumn{1}{l}{ NO } & EXPLANATION \\
\hline & $\mathbf{X}$ & \\
\hline & $\mathbf{X}$ & \\
\hline & $\mathbf{X}$ & \\
\hline $\mathbf{X}$ & & Some burrows around perimeter \\
\hline & $\mathbf{X}$ & \\
\hline & $\mathbf{X}$ & \\
& & \\
\hline & & \\
\hline
\end{tabular}

4. Vegetative cover.

a. Is perimeter fence or mesh fencing damaged?

b. Is there evidence of horses or rabbits on site?

c. Is organic mulch adequate to prevent erosion?

d. Are weedy annual plants present? If yes, are they a problem?

e. Are seeded plant species found on site?

f. Is there evidence of plant mortality?

\begin{tabular}{|l|l|l|}
\hline & $\mathbf{X}$ & \\
\hline & $\mathbf{X}$ & \\
\hline $\mathbf{X}$ & & \\
\hline $\mathbf{X}$ & & Halogeton present but not abundant \\
\hline $\mathbf{X}$ & & See attached report \\
\hline $\mathbf{X}$ & & $\begin{array}{l}\text { See attached report. Some die-off probably } \\
\text { due to drought }\end{array}$ \\
\hline
\end{tabular}

5. Photo Documentation

a. Has a photo log been prepared?

b. Number of photos exposed (Three, attached to report)

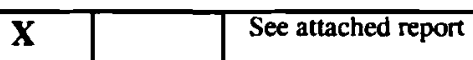

\section{FIELD CONCLUSIONS}

2. Is there an imminent hazard to the integrity of the unit? (Immediate report required)

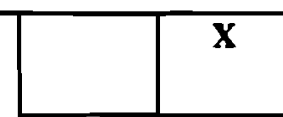

Person/Agency to whom report made

2. Are more frequent inspections required?

3. Are existing maintenance/repair actions satisfactory?

4. Is other maintenance/repair necessary?

5. Is current status/condition of vegetative cover satisfactory?

6. Rationale for field conclusions: Density and cover data collected in 2003

\section{E. CERTIFICATION}

I have conducted an inspection of the Bomblet Pit, at the TTR in accordance with the Post-Closure Monitoring Plan (see Closure Report) as recorded on this checklist. attached sheets, field notes, photo logs, and photographs.

Chief Inspector's Signanre:

Printed Name: David C. Anderson

Title: Sr. Scientis

Date: Sept. 8, 2003 


\section{CAU 404: ROLLER COASTER LAGOONS \& TRENCH, POST-CLOSURE MONITORING CHECKLIST}

Date of Last Inspection: June 3, 2002 Reason for Last Inspection: Annual Monitoring

Responsible Agency: Bechtel Nevada Project Manager: R. Jackson

Inspection Date: September 9,2003

Inspector (name, title, organization): David C. Anderson, Scientist, Bechtel Nevada

Assistant Inspector (name, title, organization): W. Kent Ostler, Scientist, Bechtel Nevada

\section{A. GENERAL INSTRUCTIONS}

1. All checklist items must be completed and detailed comments made to document the results of the site inspection. The completed checklist is part of the field record of the inspection. Additional pages should be used as necessary to ensure that a complete record is made. Attach the additional pages and number all pages upon completion of the inspection.

3. Any checklist line item marked by an inspector in a SHADED BOX, must be fully explained or an appropriate reference to previous reports provided. The purpose of this requirement is to provide a written explanation of inspector observations and the inspector's rationale for conclusions and recommendations. Explanations are to be placed on additional attachments and cross-referenced appropriately. Explanations, in addition to narrative, will take the form of sketches, measurements, annotated site maps.

4. The site inspection is a walking inspection of the entire site including the perimeter and sufficient transects to be able to inspect the entire surface and all features specifically described in this checklist.

5. A standard set of color $35 \mathrm{~mm}$ photographs is required. In addition, all anomalous features or new features (such as changes in adjacent area land use) are to be photographed. A photo log entry will be made for each photograph taken.

6. This unit will be inspected biannually with formal reporting to the Nevada Division of Environmental Protection to be done annually. The annual report will include an executive summary, this inspection checklist with field notes and photo log antached, and recommendations and conclusions.

\section{B. PREPARATION (To be completed prior to site visit)}

1. Site as-built plans and site base map reviewed.

2. Previous inspection reports reviewed.

a. Were anomalies or trends detected on previous inspections?

b. Was maintenance performed?

3. Site maintenance and repair records reviewed.

a. Has site repair resulted in a change from as-built conditions?

b. Are revised as-builts available that refiect repair changes?

C. SITE INSPECTION (To be completed during inspection)

\begin{tabular}{|l|l|l|}
\hline YES & NO & EXPLANATION \\
\hline & & \\
\hline & & \\
\hline & & \\
\hline & & \\
\hline & & \\
\hline YES & NO & EXPLANATION \\
\hline
\end{tabular}

1. Adjacent off-site features within watershed areas.

a. Have there been any changes in use of adjacent area?

b. Are there any new roads or trails?

c. Has there been a change in the position of nearby washes?

d. Has there been lateral excursion or erosion/deposition of nearby washes?

e. Are there new drainage channels?

f. Change in surrounding vegetation?

\begin{tabular}{|l|l|l|}
\hline & $\mathbf{X}$ & \\
\hline & $\mathbf{X}$ & \\
\hline $\mathbf{X}$ & $\mathbf{X}$ & $\begin{array}{l}\text { Not from wash but runoff that comes down road } \\
\text { to site and fans onto revegetated area }\end{array}$ \\
\hline $\mathbf{X}$ & & $\begin{array}{l}\text { Along south edge of cover cap, small channel } \\
\text { forming from runoff that comes down road and } \\
\text { onto site }\end{array}$ \\
\hline & $\mathbf{X}$ & \\
\hline
\end{tabular}

2. Security fence, signs.

a. Displacement of fences, site markers, boundary markers, or monuments?

b. Have any signs been damaged or removed? (Number of signs replaced:

c. Were gates locked?

\begin{tabular}{|l|c|l|}
\hline & $\mathbf{X}$ & \\
\hline & $\mathbf{X}$ & \\
\hline $\mathbf{X}$ & & Gate shut, no locks present \\
\hline
\end{tabular}


CAU 404: ROLLER COASTER LAGOONS \& TRENCH, POST-CLOSURE MONITORING CHECKLIST

3. Waste Unit cover.

a. Is there evidence of settling?

b. Is there cracking?

c. Is there evidence of erosion around the cap (wind or water)?

d. Is there evidence of animal burrowing?

e. Have the site markers been disturbed by man or natural processes?

f. Do natural processes threaten to integrity of any cover or site marker?

g. Other?

\begin{tabular}{|l|c|l|}
\hline \multicolumn{1}{|c|}{ YES } & NO & \multicolumn{1}{l|}{ EXPLANATION } \\
\hline & $\mathbf{X}$ & \\
\hline $\mathbf{X}$ & $\mathbf{X}$ & \\
\hline $\mathbf{X}$ & & \\
\hline & $\mathbf{X}$ & \\
\hline & $\mathbf{X}$ & \\
& & \\
\hline & & \\
\hline
\end{tabular}

4. Vegetative cover.

a. Is perimeter fence or mesh fencing damaged?

b. Is there evidence of horses or rabbits on site?

c. Is organic mulch adequate to prevent erosion?

d. Are weedy annual plants present? If yes, are they a problem?

e. Are seeded plant species found on site?

f. Is there evidence of plant mortality?

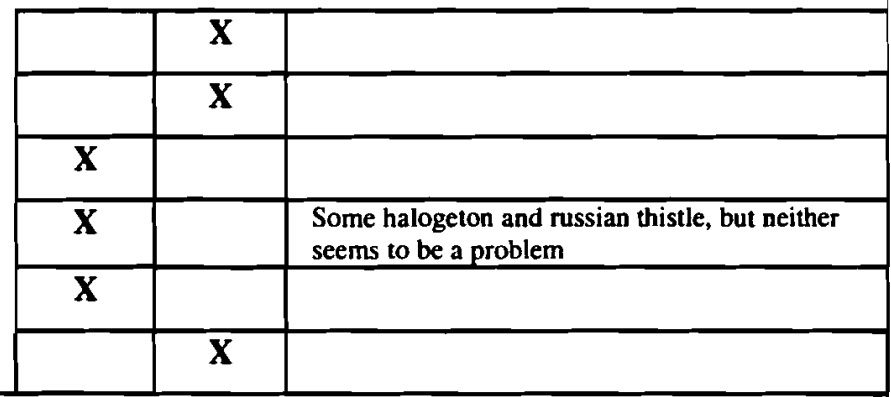

5. Photo Documentation

a. Has a photo log been prepared?

$\mathbf{X}$

c. Number of photos exposed (Six attached to report)

\section{FIELD CONCLUSIONS}

3. Is there an imminent hazard to the integrity of the unit? (Immediate report required)

$\mathbf{X}$

Person/Agency to whom report made:

2. Are more frequent inspections required?

3. Are existing maintenance/repair actions satisfactory?

4. Is other maintenance/repair necessary?

5. Is current status/condition of vegetative cover satisfactory?

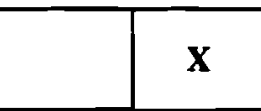

6. Rationale for field conclusions: Collection of field data, plant density and cover and observations

\section{E. CERTIFICATION}

I have conducted an inspection of the Roller Coaster Sewage Lagoons \& North Disposal Trench. CAU 404, at the TTR in accordance with the PostClosure Monitoring Plan (see Closure Report) as recorded on this checklist, attached sheets, field notes, photo logs, and photographs.

Chief Inspector's Signature:

Printed Name: David C. Anderson

Title: Sr. Scientist

Date: Sept. 9, 2003 


\section{CAU 426: CACTUS SPRINGS WASTE TRENCHES, POST.CLOSURE MONITORING CHECKLIST}

\begin{tabular}{|l|l|}
\hline Date of Last Inspection: June 3, 2002 & Reason for Last Inspection: Annual Monitoring \\
\hline Responsible Agency: Bechtel Nevada & Project Manager: R. Jackson \\
\hline Inspection Date: September 9, 2003 & \\
\hline Inspector (name, title, organization): David C. Anderson, Scientist, Bechtel Nevada \\
\hline Assistant Inspector (name, title, organization): W. Kent Ostler, Scientist, Bechtel Nevada \\
\hline \hline
\end{tabular}

\section{A. GENERAL INSTRUCTIONS}

1. All checklist items must be completed and detailed comments made to document the results of the site inspection. The completed checklist is part of the field record of the inspection. Additional pages should be used as necessary to ensure that a complete record is made. Attach the additional pages and number all pages upon completion of the inspection.

3. Any checklist line item marked by an inspector in a SHADED BOX, must be fully explained or an appropriate reference to previous reports provided. The purpose of this requirement is to provide a written explanation of inspector observations and the inspector's rationale for conclusions and recommendations. Explanations are to be placed on additional attachments and cross-referenced appropriately. Explanations, in addition to narrative, will take the form of sketches, measurements, annotated site maps.

4. The site inspection is a walking inspection of the entire site including the perimeter and sufficient transects to be able to inspect the entire surface and all features specifically described in this checklist.

5. A standard set of color $35 \mathrm{~mm}$ photographs is required. In addition, all anomalous features or new features (such as changes in adjacent area land use) are to be photographed. A photo log entry will be made for each photograph taken.

6. This unit will be inspected biannually with formal reporting to the Nevada Division of Environmental Protection to be done annually. The annual report will include an executive summary, this inspection checklist with field notes and photo log attached, and recommendations and conclusions.

\section{B. PREPARATION (To be completed prior to site visit)}

1. Site as-built plans and site base map reviewed.

2. Previous inspection reports reviewed.

a. Were anomalies or trends detected on previous inspections?

b. Was maintenance performed?

3. Site maintenance and repair records reviewed.

a. Has site repair resulted in a change from as-built conditions?

b. Are revised as-builts available that reflect repair changes?

C. SITE INSPECTION (To be completed during inspection)

\begin{tabular}{|l|l|l|l|} 
& YES & NO & EXPLANATION \\
\hline \multirow{3}{*}{} & & & \\
\cline { 2 - 4 } & & & \\
\cline { 2 - 4 } & & & \\
\hline \multirow{3}{*}{ ins? } & & & \\
\cline { 2 - 4 } & & & \\
\cline { 2 - 4 } & & & \\
\hline & YES & NO & EXPLANATION \\
\hline
\end{tabular}

1. Adjacent off-site features within watershed areas.

a. Have there been any changes in use of adjacent area?

b. Are there any new roads or trails?

c. Has there been a change in the position of nearby washes?

d. Has there been lateral excursion or erosion/deposition of nearby washes?

e. Are there new drainage channels?

f. Change in surrounding vegetation?

\begin{tabular}{|l|l|l|}
\hline & $\mathbf{X}$ & \\
\hline & $\mathbf{X}$ & \\
\hline & $\mathbf{X}$ & \\
\hline & $\mathbf{X}$ & \\
\hline & $\mathbf{X}$ & \\
\hline & $\mathbf{X}$ & \\
\hline
\end{tabular}

2. Security fence, signs.

a. Displacement of fences, site markers, boundary markers, or monuments?

b. Have any signs been damaged or removed?

(Number of signs replaced:

c. Were gates locked?

\begin{tabular}{|l|c|l|}
\hline & $\mathbf{X}$ & \\
\hline & $\mathbf{X}$ & \\
\hline $\mathbf{X}$ & & Gate shut, no lock present \\
\hline
\end{tabular}




\section{CAU 426: CACTUS SPRINGS WASTE TRENCHES, POST-CLOSURE MONITORING CHECKLIST}

3. Waste Unit cover.

\begin{tabular}{|l|c|l|}
\multicolumn{1}{c}{ YES } & \multicolumn{1}{c}{ NO } & EXPLANATION \\
\hline & $\mathbf{X}$ & \\
\hline & $\mathbf{X}$ & \\
\hline & $\mathbf{X}$ & \\
\hline & $\mathbf{X}$ & \\
\hline & $\mathbf{X}$ & \\
\hline & $\mathbf{X}$ & \\
& & \\
\hline & & \\
\hline
\end{tabular}

a. Is there evidence of settling?

b. Is there cracking?

c. Is there evidence of erosion around the cap (wind or water)?

d. Is there evidence of animal burrowing?

e. Have the site markers been disturbed by man or natural processes?

f. Do natural processes threaten to integrity of any cover or site marker?

g. Other?

4. Vegetative cover.

a. Is perimeter fence or mesh fencing damaged?

b. Is there evidence of horses or rabbits on site?

c. Is organic mulch adequate to prevent erosion?

d. Are weedy annual plants present? If yes, are they a problem?

e. Are seeded plant species found on site?

f. Is there evidence of plant mortality?

\begin{tabular}{|l|l|l|}
\hline & $\mathbf{X}$ & \\
\hline & $\mathbf{X}$ & \\
\hline $\mathbf{X}$ & & \\
\hline & $\mathbf{X}$ & In spots halogeton is abundant \\
\hline $\mathbf{X}$ & & See attached report \\
\hline & $\mathbf{X}$ & \\
\hline
\end{tabular}

5. Photo Documentation

a. Has a photo log been prepared?

\begin{tabular}{|l|l|l|}
\hline $\mathbf{X}$ & & See attached report \\
\hline
\end{tabular}

c. Number of photos exposed (Six attached to report)

\section{FIELD CONCLUSIONS}

4. Is there an imminent hazard to the integrity of the unit? (Immediate report required)

$\mathbf{X}$

Person/Agency to whom report made:

2. Are more frequent inspections required?

3. Are existing maintenance/repair actions satisfactory?

4. Is other maintenance/repair necessary?

5. Is current status/condition of vegetative cover satisfactory?

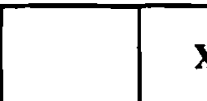

6. Rationale for field conclusions: Collection of field plant density and cover data, field observations

\section{E. CERTIFICATION}

I have conducted an inspection of the Cactus Spring Waste Trenches, CAU 426, at the TTR in accordance with the Post-Closure Monitoring Plan (see Closure Report) as recorded on this checklist. attached sheets, field notes, photo logs, and photographs. 
CAU 407: ROLLERCOASTER RADSAFE Area, POST-CLOSURE MONITORING CHECKLIST

\begin{tabular}{|l|l|}
\hline Date of Last Inspection: June 3, 2002 & Reason for Last Inspection: Annual Monitoring \\
\hline Responsible Agency: Bechtel Nevada & Project Manager: R. Jackson \\
\hline Inspection Date: September 9, 2003 & \\
\hline Inspector (name, title, organization): David C. Anderson, Scientist, Bechtel Nevada \\
\hline Assistant Inspector (name, title, organization): W. Kent Ostler, Scientist, Bechtel Nevada \\
\hline \hline
\end{tabular}

\section{A. GENERAL INSTRUCTIONS}

1. Afl checklist items must be completed and detailed comments made to document the results of the site inspection. The completed checklist is part of the field record of the inspection. Additional pages should be used as necessary to ensure that a complete record is made. Attach the additional pages and number all pages upon completion of the inspection.

3. Any checklist line item marked by an inspector in a SHADED BOX, must be fully explained or an appropriate reference to previous reports provided. The purpose of this requirement is to provide a written explanation of inspector observations and the inspector's rationale for conclusions and recommendations. Explanations are to be placed on additional attachments and cross-referenced appropriately. Explanations, in addition to narrative, will take the form of sketches, measurements, annotated site maps.

4. The site inspection is a walking inspection of the entire site including the perimeter and sufficient transects to be able to inspect the entire surface and all features specifically described in this checklist.

5. A standard set of color $35 \mathrm{~mm}$ photographs is required. In addition, all anomalous features or new features (such as changes in adjacent area land use) are to be photographed. A photo log entry will be made for each photograph taken.

6. This unit will be inspected biannually with formal reporting to the Nevada Division of Environmental Protection to be done annually. The annual report will include an executive summary, this inspection checklist with field notes and photo log attached, and recommendations and conclusions.

\begin{tabular}{|c|c|c|c|}
\hline B. PREPARATION (To be completed prior to site visit) & YES & No & EXPLANATION \\
\hline 1. Site as-built plans and site base map reviewed. & & & \\
\hline \multicolumn{4}{|l|}{ 2. Previous inspection reports reviewed. } \\
\hline a. Were anomalies or trends detected on previous inspections? & & & \\
\hline b. Was maintenance performed? & & & \\
\hline \multicolumn{4}{|l|}{ tenance and repair records reviewed. } \\
\hline a. Has site repair resulted in a change from as-built conditions? & & & \\
\hline b. Are revised as-builts available that reflect repair changes? & & & \\
\hline C. SITE INSPECTION (To be completed during inspection) & YES & NO & EXPLANATION \\
\hline
\end{tabular}

1. Adjacent off-site features within watershed areas.

a. Have there been any changes in use of adjacent area?

b. Are there any new roads or trails?

c. Has there been a change in the position of nearby washes?

d. Has there been lateral excursion or erosion/deposition of nearby washes?
e. Are there new drainage channels?
f. Change in surrounding vegetation?

\begin{tabular}{|l|l|l|}
\hline & $\mathbf{X}$ & \\
\hline & $\mathbf{X}$ & \\
\hline & $\mathbf{X}$ & \\
\hline $\mathbf{X}$ & & $\begin{array}{l}\text { Standing water accumulating behind dam } \\
\text { formed by access road and cap }\end{array}$ \\
\hline $\mathbf{X}$ & & Along northern edge of cap, small channel \\
\hline & $\mathbf{X}$ & \\
\hline
\end{tabular}

2. Security fence, signs.

a. Displacement of fences, site markers, boundary markers, or monuments?

b. Have any signs been damaged or removed?

(Number of signs replaced:

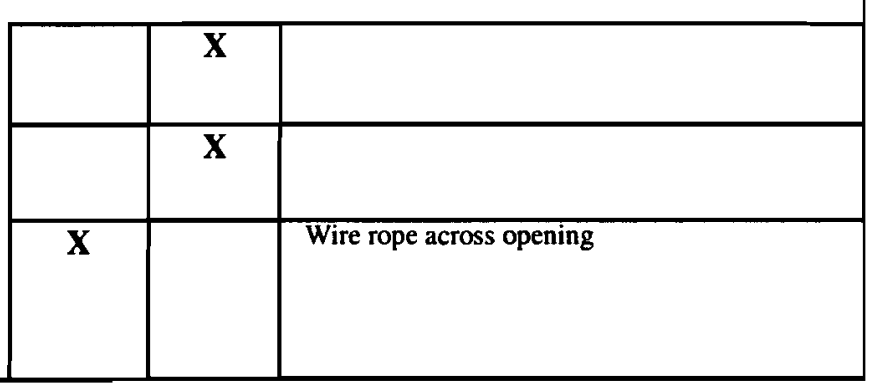

c. Were gates locked? 


\section{CAU 407: ROLLERCOASTER RAD-SAFE COVER CAP, POST-CLOSURE MONITORING CHECKLIST}

3. Waste Unit cover.

a. Is there evidence of settling?

b. Is there cracking?

c. Is there evidence of erosion around the cap (wind or water)?

d. Is there evidence of animal burrowing?

e. Have the site markers been disturbed by man or natural processes?

f. Do natural processes threaten to integrity of any cover or site marker?

g. Other?

\begin{tabular}{|l|c|l|}
\multicolumn{1}{l|}{ YES } & NO & EXPLANATION \\
\hline & $\mathbf{X}$ & \\
\hline $\mathbf{X}$ & $\mathbf{X}$ & \\
\hline $\mathbf{X}$ & & Erosion off eastern edge of cap \\
\hline & $\mathbf{X}$ & \\
\hline & $\mathbf{X}$ & \\
& & \\
\hline & & \\
\hline
\end{tabular}

4. Vegetative cover.

a. Is perimeter fence or mesh fencing damaged?

b. Is there evidence of horses or rabbits on site?

c. Is organic mulch adequate to prevent erosion?

d. Are weedy annual plants present? If yes, are they a problem?

e. Are seeded plant species found on site?

f. Is there evidence of plant mortality?

\begin{tabular}{|l|l|l|}
\hline & $\mathbf{X}$ & \\
\hline & $\mathbf{X}$ & $\begin{array}{l}\text { Did not sample inside fence, could not confirm } \\
\text { rabbit use. }\end{array}$ \\
\hline & $\mathbf{X}$ & Bare soils \\
\hline & $\mathbf{X}$ & $\begin{array}{l}\text { Halogeton, unable to determine if problem or } \\
\text { not }\end{array}$ \\
\hline & $\mathbf{X}$ & Only few annual weedy species \\
\hline & $\mathbf{X}$ & \\
\hline
\end{tabular}

5. Photo Documentation

a. Has a photo log been prepared?

$\mathbf{X}$

c. Number of photos exposed (Three attached to report)

\section{FIELD CONCLUSIONS}

5. Is there an imminent hazard to the integrity of the unit? (Immediate report required)

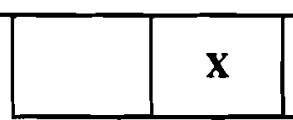

Person/Agency to whom report made:

2. Are more frequent inspections required?

3. Are existing maintenance/repair actions satisfactory?

4. Is other maintenance/repair necessary?

5. Is current status/condition of vegetative cover satisfactory?

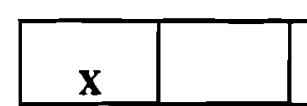

6. Rationale for field conclusions: Field observation and photographs

\section{E. CERTIFICATION}

1 have conducted an inspection of the Rollercoaster RADSAFE area, CAU 407, at the TTR in accordance with the Post-Closure Monitoring Plan (see Closure Report) as recorded on this checklist, attached sheets, field notes, photo logs, and photographs.

Chief Inspector's Signature:

Printed Name: David C. Anderson

Title: Sr. Scientist

Date: Sept. 9, 2003 
APPENDIX C

Photographic Reference Points 
THIS PAGE INTENTIONALLY LEFT BLANK 


\section{CAU 400-BOMBLET PIT}
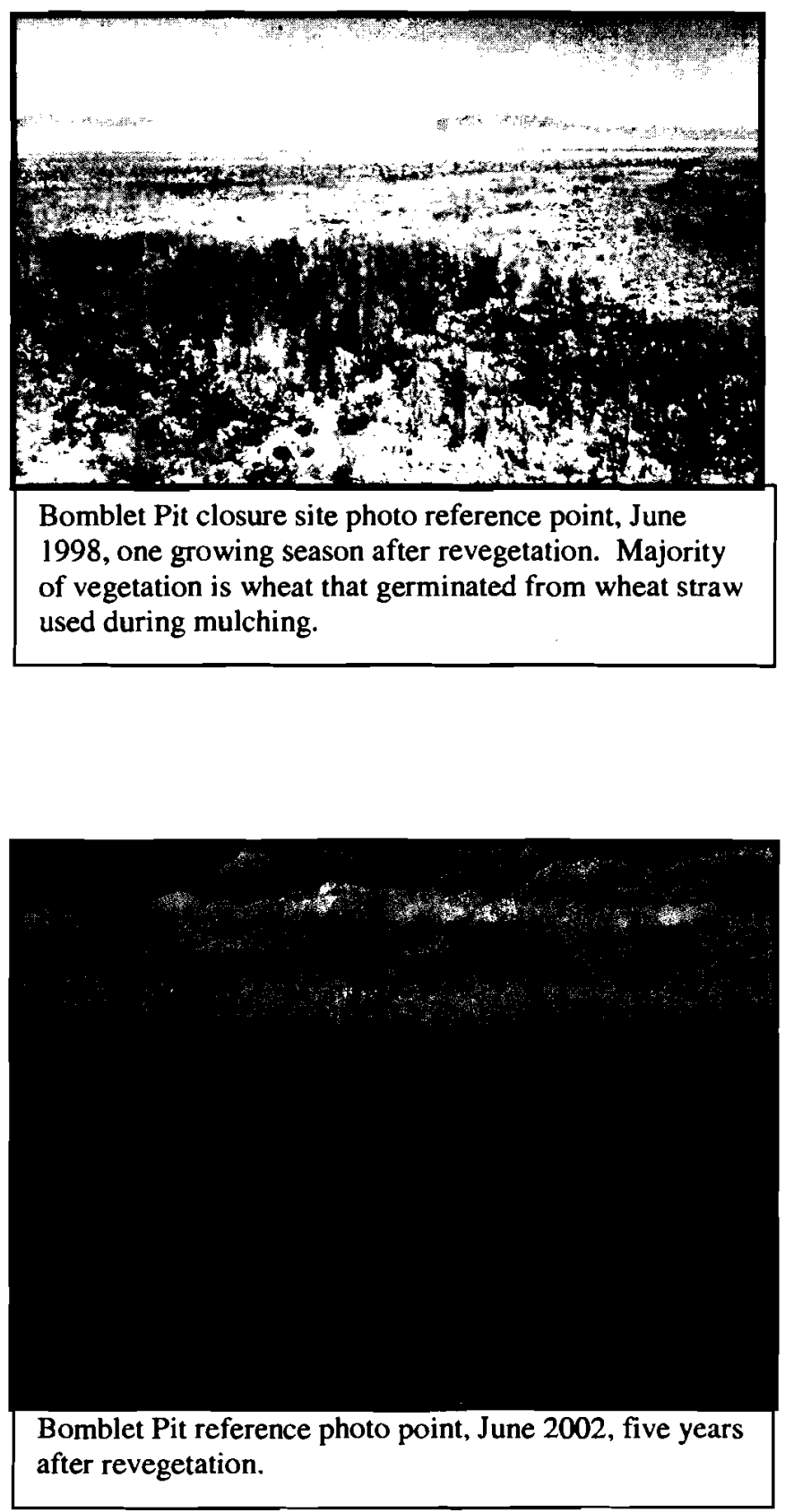

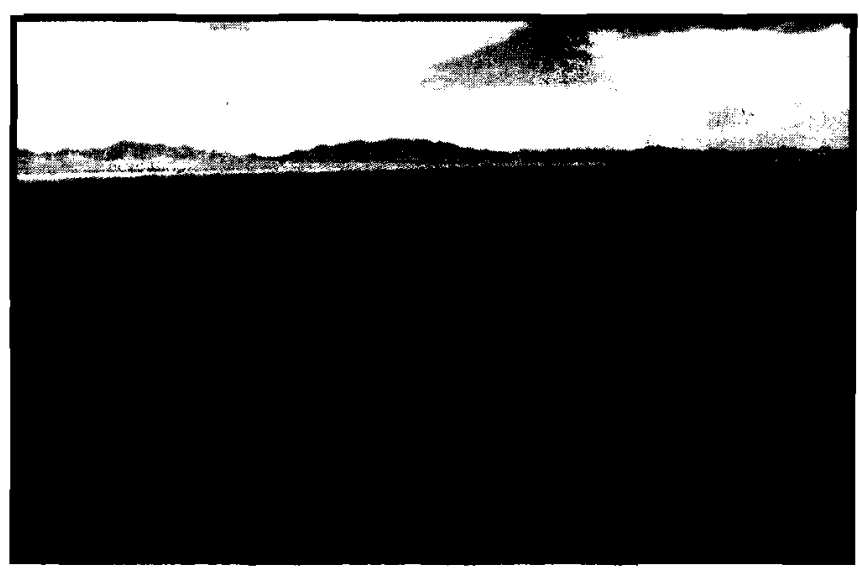

Bomblet Pit reference photo point, June 2000, three growing seasons after revegetation. Vegetation appears dry because photo taken late in growing season and wheat is no longer present on the site.

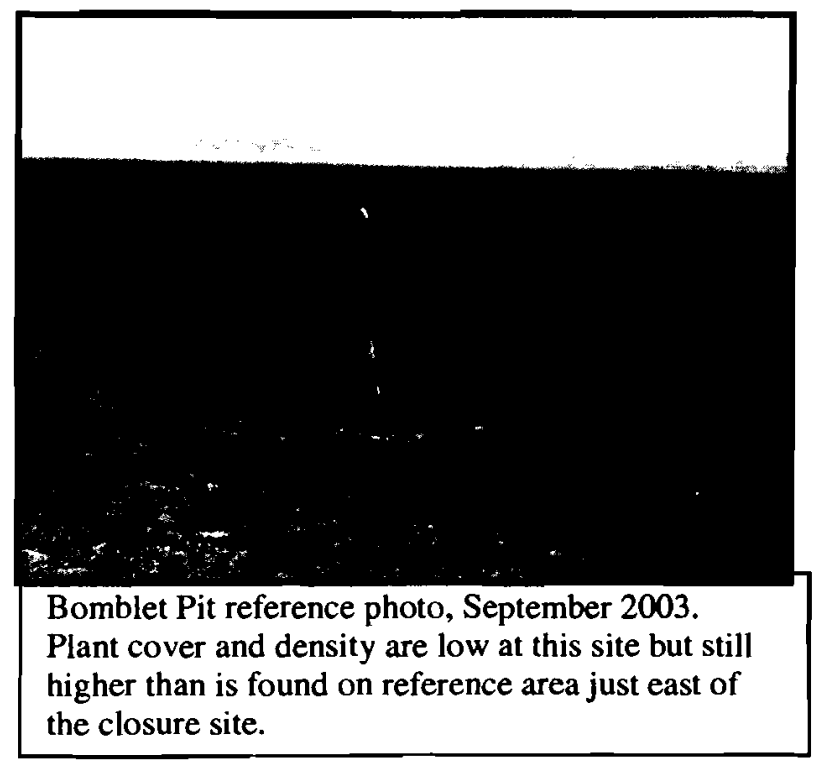




\section{CAU 404-ROLLER COASTER SEWAGE LAGOONS COVER CAP}
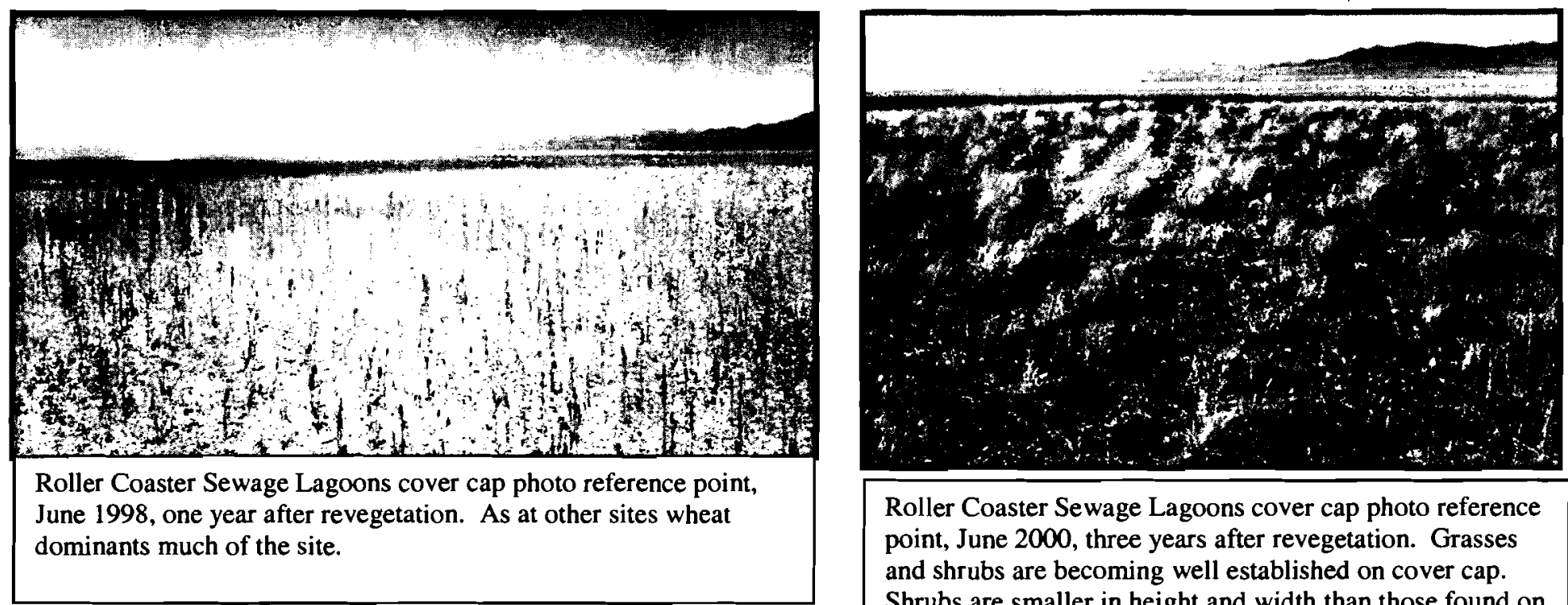

Roller Coaster Sewage Lagoons cover cap photo reference point, June 2000, three years after revegetation. Grasses and shrubs are becoming well established on cover cap. Shrubs are smaller in height and width than those found on the staging area, but shrub vigor is very good.
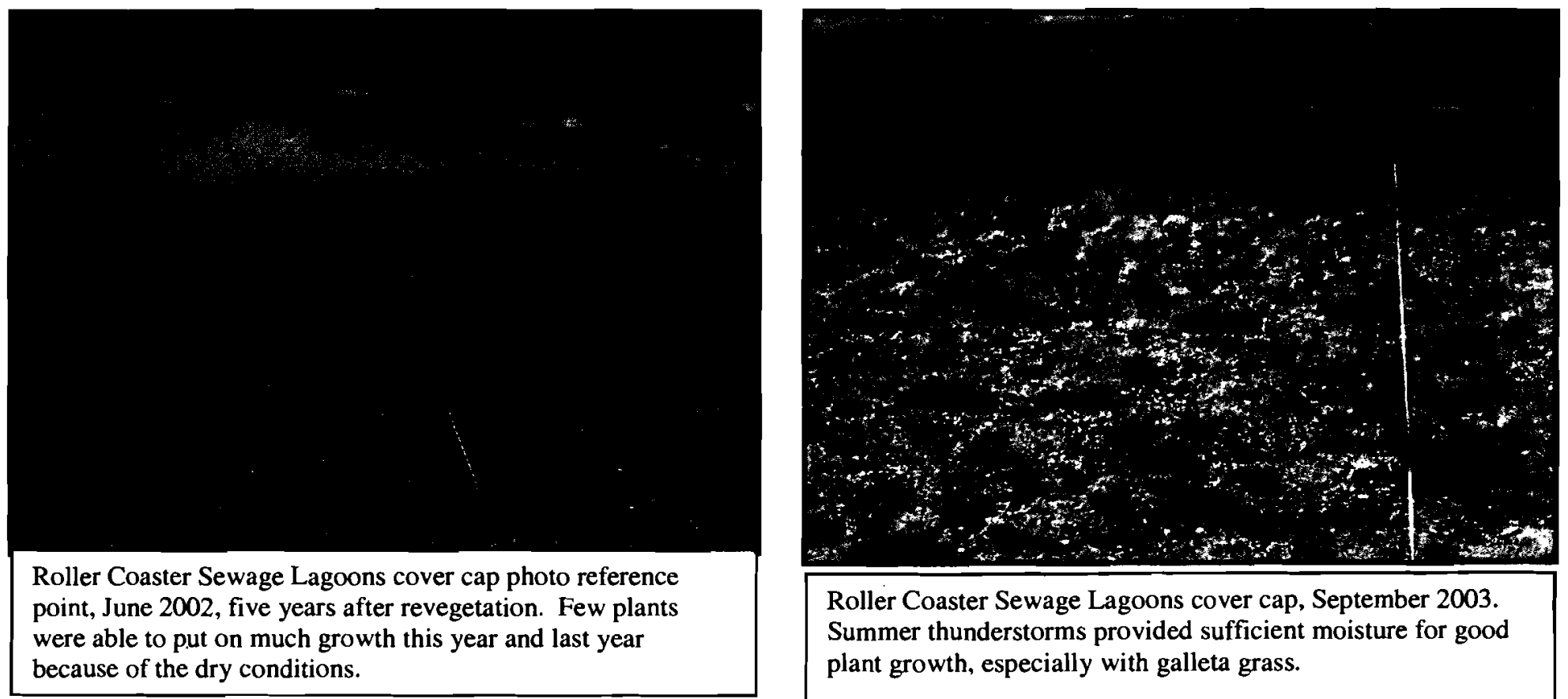

Roller Coaster Sewage Lagoons cover cap, September 2003. Summer thunderstorms provided sufficient moisture for good plant growth, especially with galleta grass. 


\section{CAU 404-ROLLER COASTER SEWAGE LAGOONS STAGING AREA}

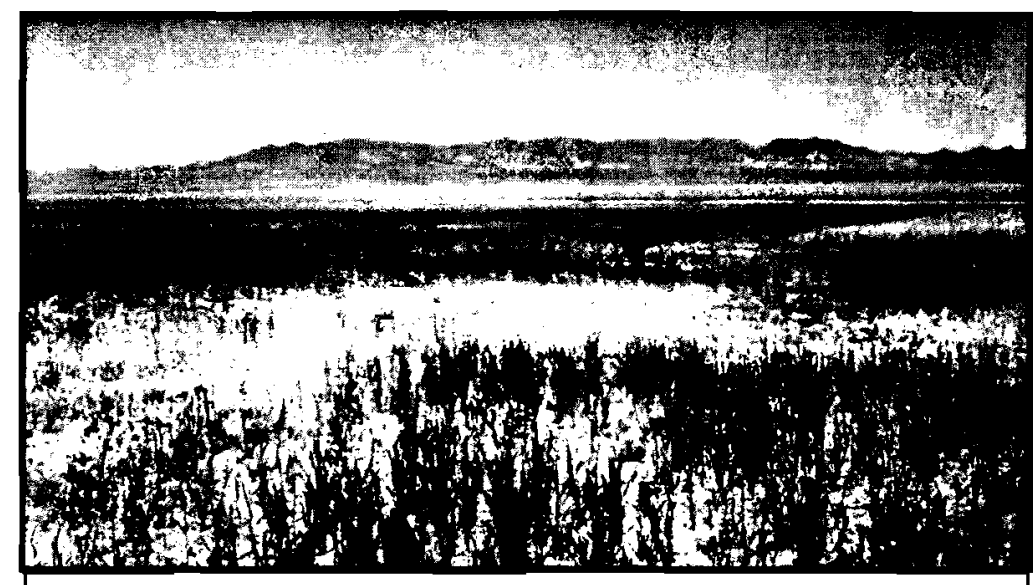

Roller Coaster Sewage Lagoons staging area photo reference point, June 1998, one year after revegetation. Wheat dominants the overall appearance of the site, however, there are numerous seedlings of grasses and shrubs emerging through the layer of straw mulch.

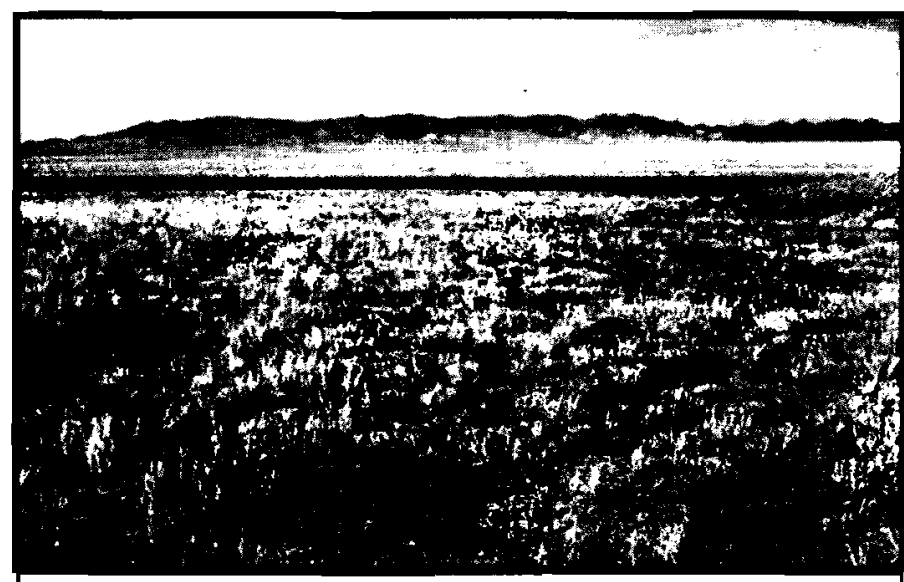

Roller Coaster Sewage Lagoons staging area photo reference point, June 2000 , three years after revegetation. Little, if any, wheat is seen on the site. A good mix of shrubs and grasses are establishing. In the foreground several plants of halogeton are seen invading the site. The dominant shrub is shadscale with some fourwing saltbush and budsage.

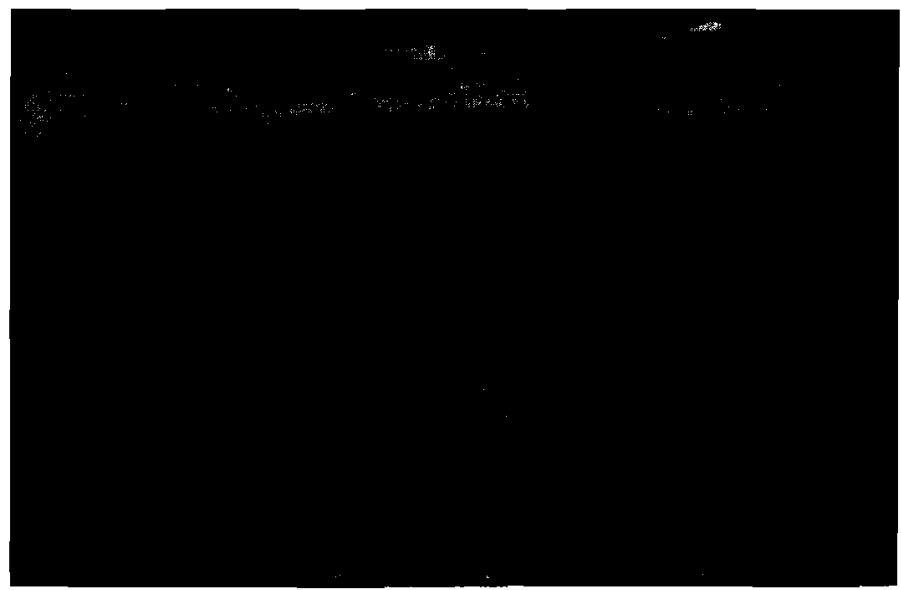

Roller Coaster Sewage Lagoons staging area photo reference point, June 2002 , five years after revegetation. Dry conditions over the last couple years have left the site looking barren and brown, but there is a good mix of shrubs and grasses on the site, but they have not shown much growth this year. There was some evidence of dieoff of some individuals of shadscale, but this was

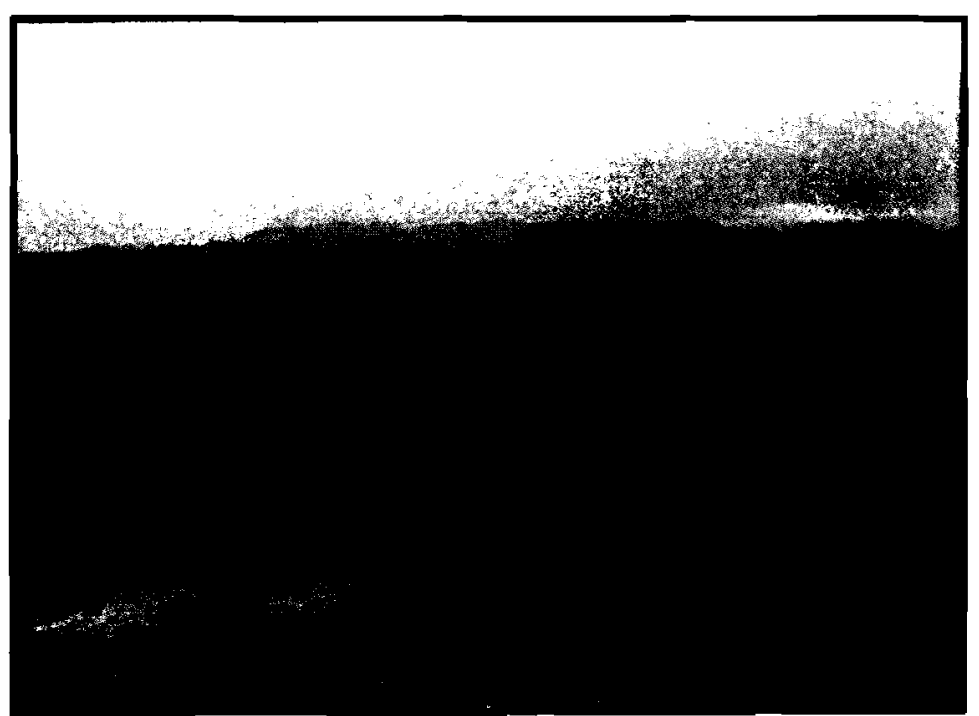

Roller Coaster Sewage Lagoons staging area, September 2003. Note in foreground signs of surface erosion from recent thunderstorms. 


\section{CAU 426-CACTUS SPRINGS WASTE TRENCH COVER CAP}
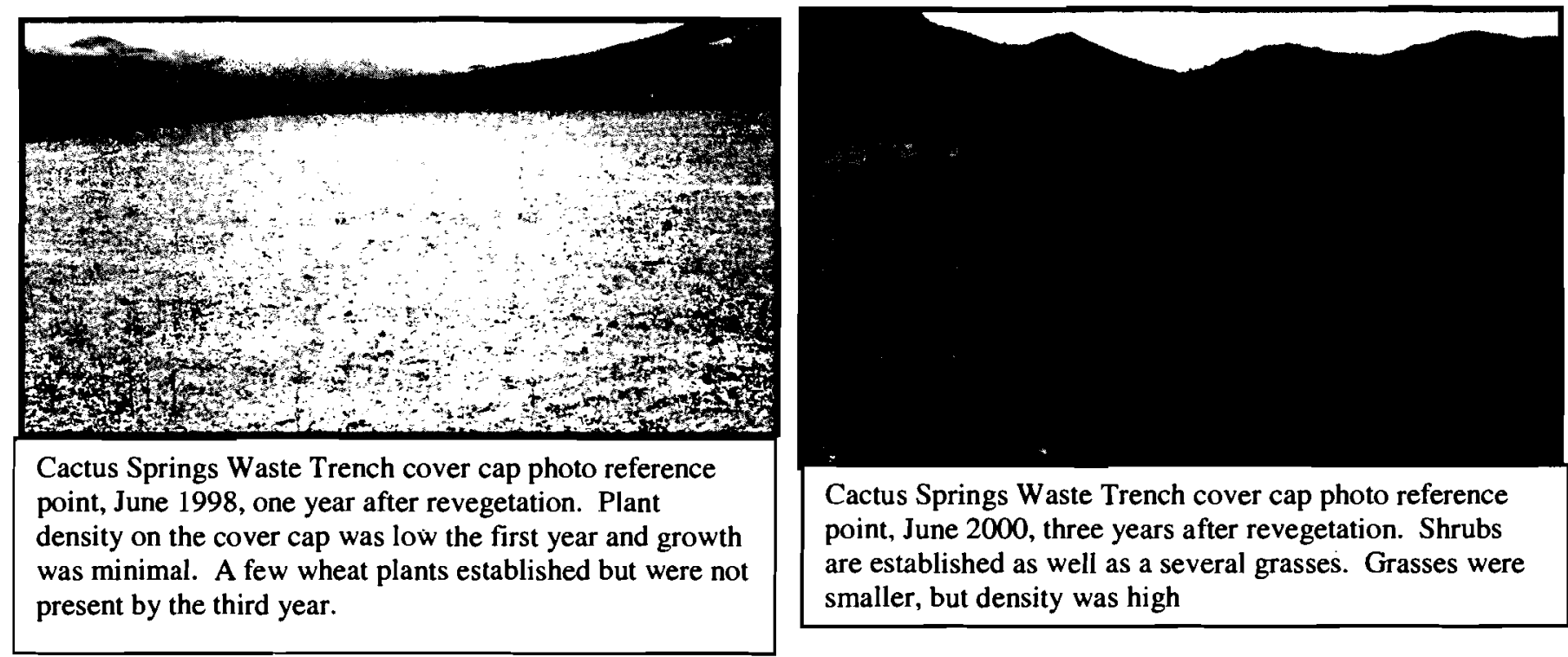

Cactus Springs Waste Trench cover cap photo reference point, June 2000 , three years after revegetation. Shrubs are established as well as a several grasses. Grasses were smaller, but density was high
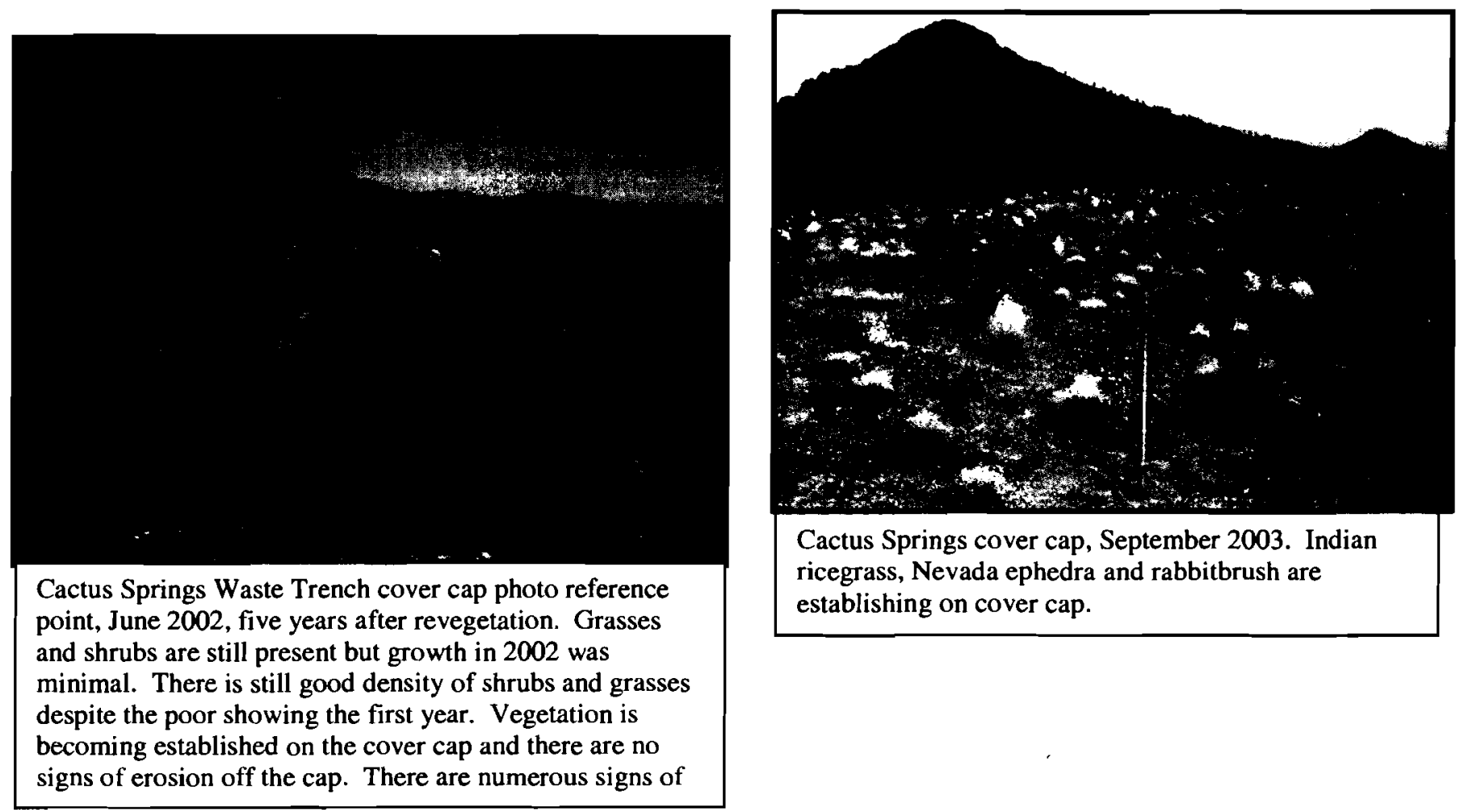


\section{CAU 426-CACTUS SPRINGS STAGING AREA}

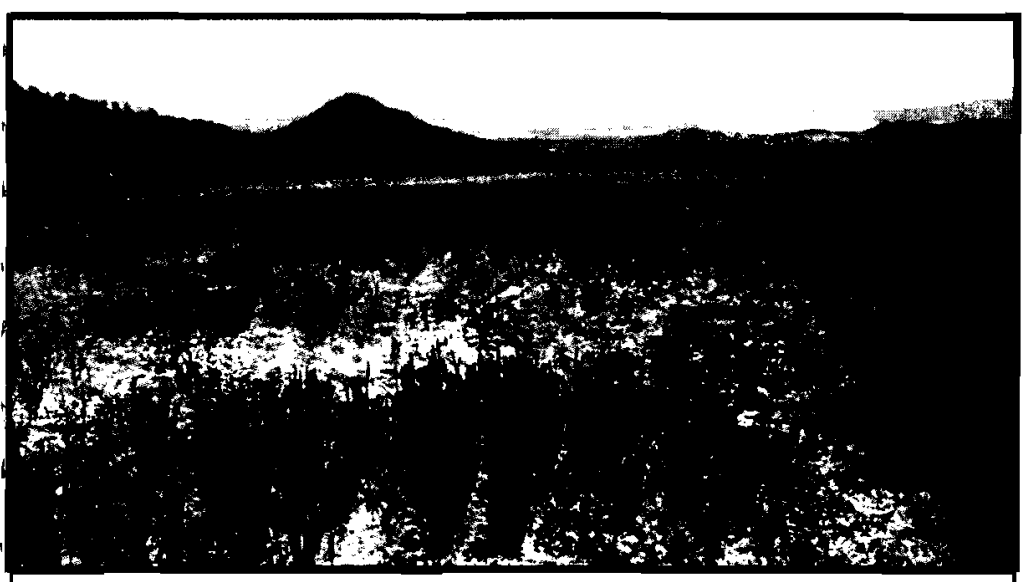

Cactus Springs Waste Trench staging area photo reference point, June 1998, one year after revegetation. As with most sites the first year's vegetation appears dominated by wheat. There is a mix of young shrub and grass seedlings beneath the canopy of wheat stalks.

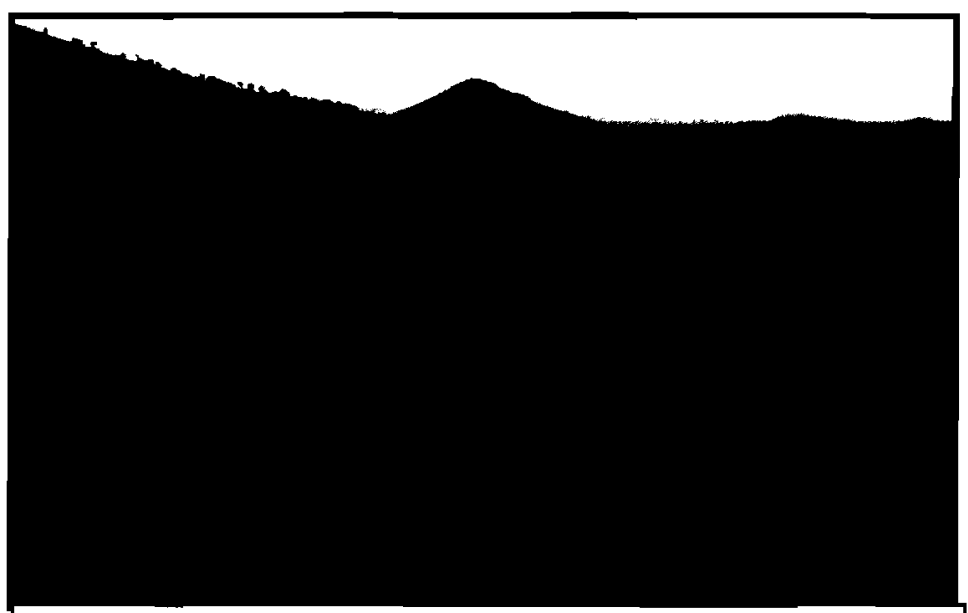

Cactus Springs Waste Trench staging area photo reference point, June 2002, five years after revegetation. Shrubs and grasses are becoming well established on the site. Plant cover and density values are a little lower at this site than at the other closure sites.

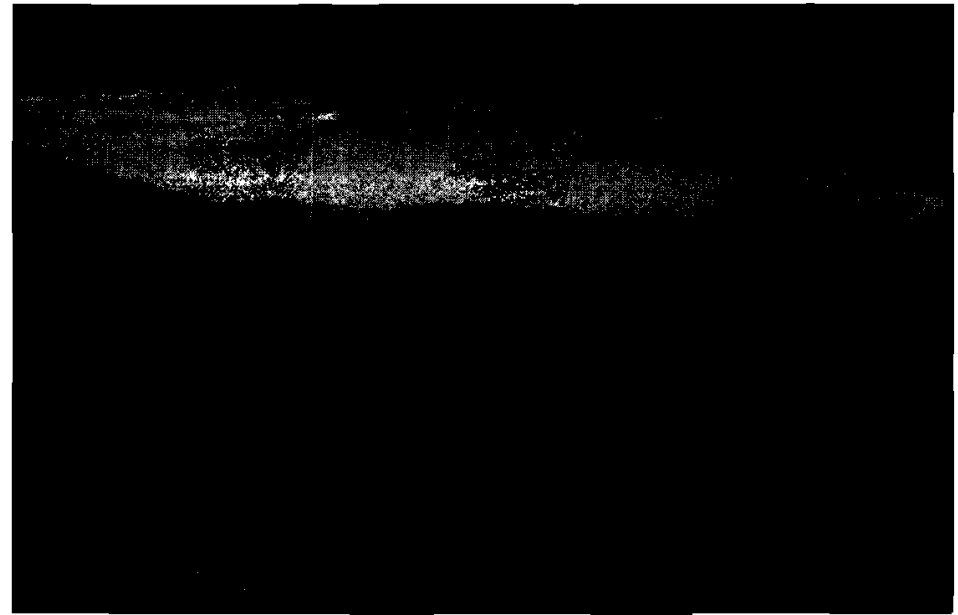

Cactus Springs Waste Trench staging area photo reference point, June 2000 , three years after revegetation. As is apparent there are numerous shrubs and grasses becoming established on the site. Because plant density and cover is lower there are barren areas that are quickly invaded by halogeton (foreground, dark tan appearance).

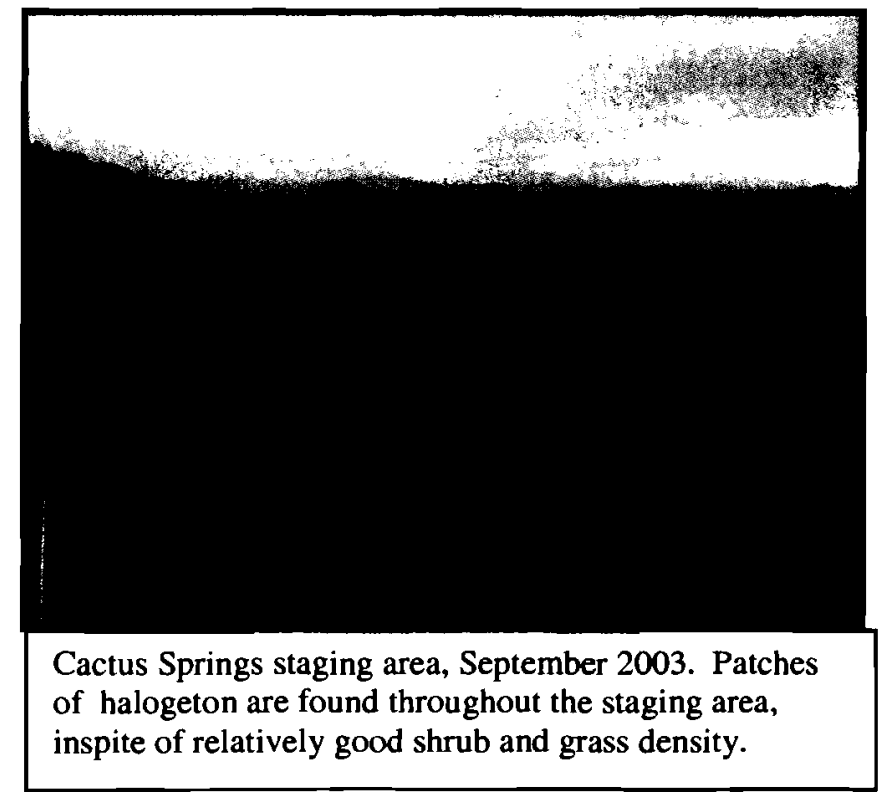



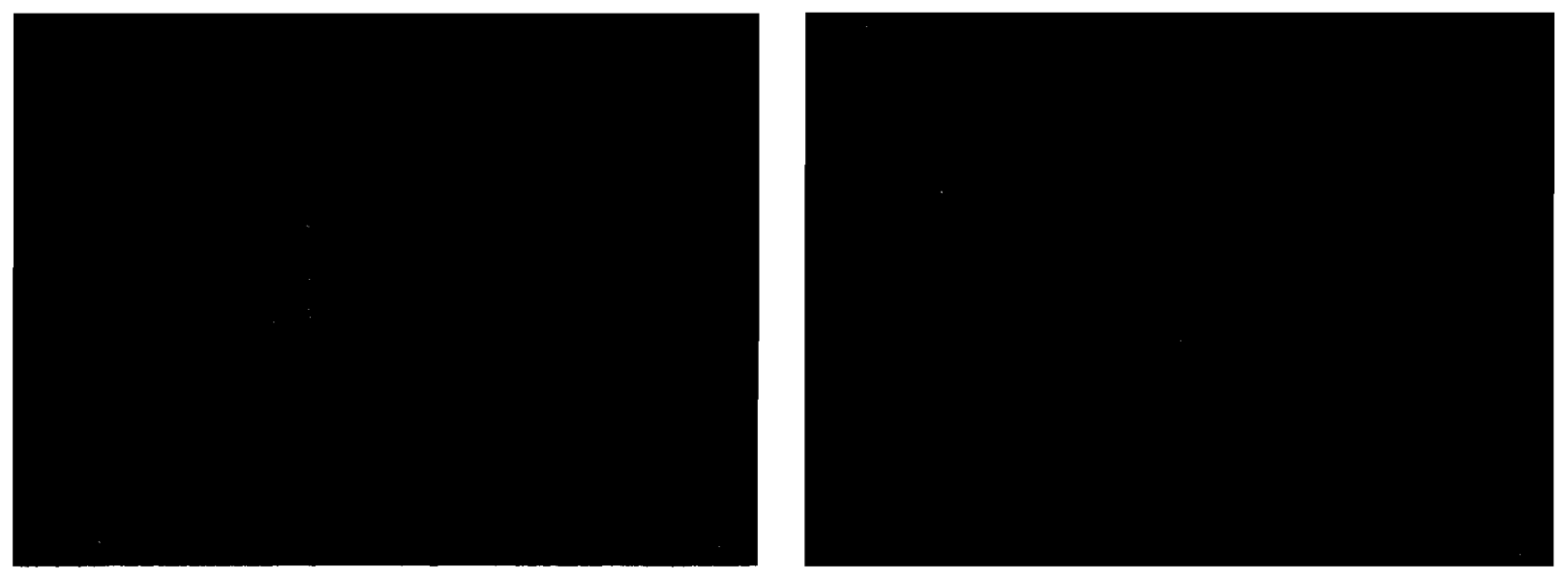

Roller Coaster RADSAFE area showing erosion channel off east edge of cover cap. Some remedial action may be necessary if erosion channel deepens. Some protection from erosion may occur as plant cover increases over the next few years.

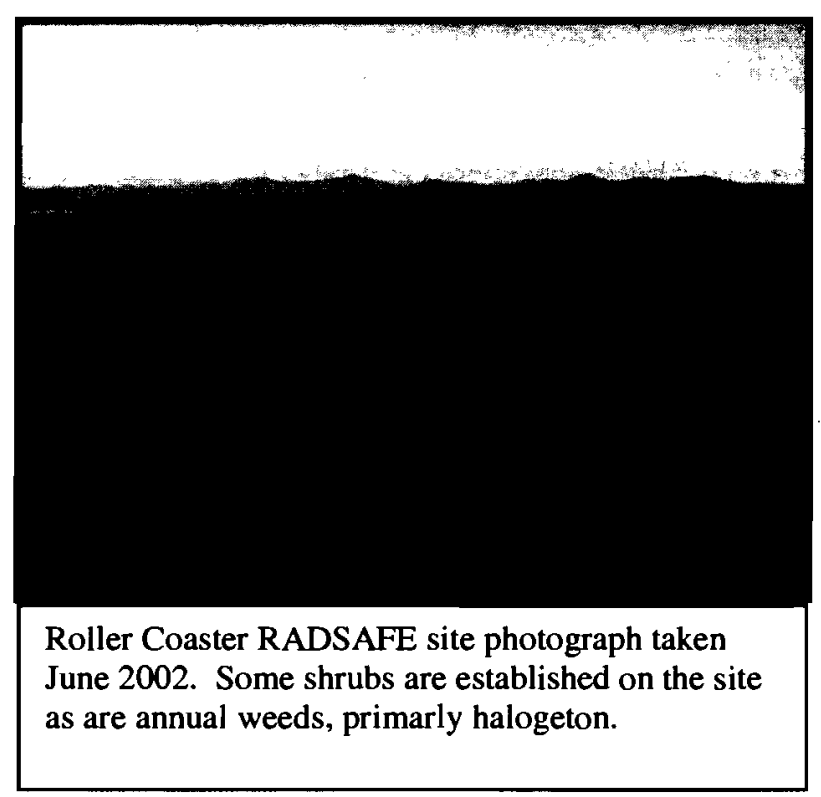

Animal burrows along edge of cover cap at the Roller Coaster RADSAFE area.

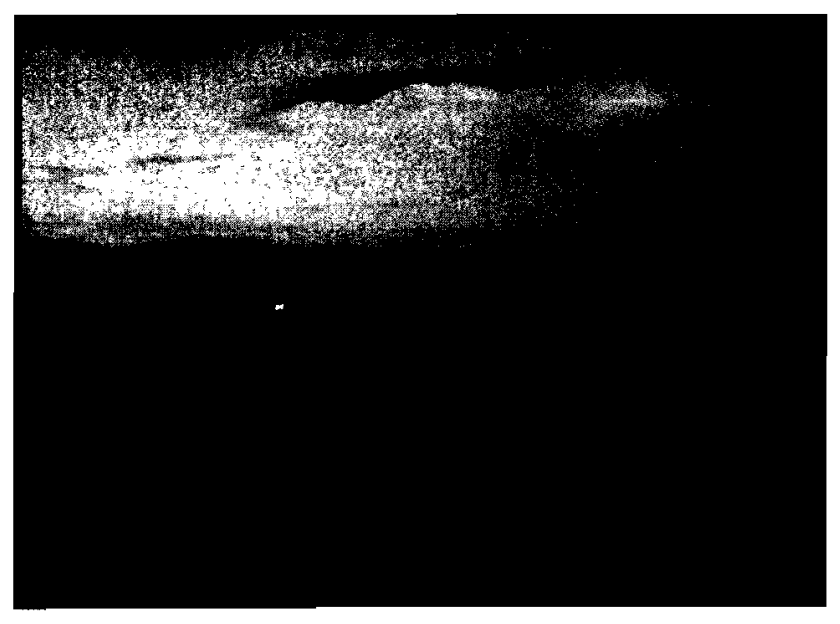

Roller Coaster RADSAFE site, September 2003. Cover is completely void of vegetation and side slopes show signs of gully erosion. 


\section{APPENDIX D \\ Plant Species List}

\begin{tabular}{|c|c|}
\hline Lifeform & $\underline{\text { Scientific Name }}$ \\
\hline Shrub & $\begin{array}{l}\text { Artemisia nova } \\
\text { Artemisia spinescens } \\
\text { Atriplex canescens } \\
\text { Atriplex confertifolia } \\
\text { Chrysothamnus greenei } \\
\text { Chrysothamnus viscidiflorus } \\
\text { Ephedra nevadensis } \\
\text { Ericameria nauseosa } \\
\text { Krascheninnikovia lanata } \\
\text { Sarcobatus vermiculatus }\end{array}$ \\
\hline Grass & $\begin{array}{l}\text { Achnatherum hymenoides } \\
\text { Elymus elymoides } \\
\text { Pleuraphis jamesii } \\
\text { Sporobolus cryptandrus }\end{array}$ \\
\hline Forb & Sphaeralcea ambigua \\
\hline Annual & $\begin{array}{l}\text { Halogeton glomeratus } \\
\text { Salsola iberica }\end{array}$ \\
\hline
\end{tabular}

Common Name

Black sagebrush

Bud sagebrush

Fourwing saltbush

Shadscale saltbush

Greene's rabbitbrush

Low rabbitbrush

Nevada jointfir

Rubber rabbitbrush

Winterfat

Black greasewood

Indian ricegrass

Bottlebrush squirreltail

Galleta grass

Sand dropseed

Desert globemallow

Halogeton

Prickley Russian thistle 
Surface Litter

1 Accumulating in place

2 Slight Movement

3 Moderate Movement

4 Extreme movement

5 Very little remaining litter

Rating

Numerical Rating

0.0 to 4.0

4.1 to 8.0

8.1 to 12.0

12.1 to 16.0

16.1 to 20.0
Pedestalling

Rills $<9 "$

1 No visual evidence 1 No visual evidence

2 Slight pedestalling

2 Rills in evidence at intervals $>10^{\prime}$

2 Rills in evidence at intervals $>10^{\prime}$

Rills $>9 "$

3 Small rock \& plant 3 Rills at $10^{\prime}$ intervals 3 Rills at $10^{\prime}$ intervals pedestalling

4 Pedestalling plants roots exposed

5 Most plants \& rocks pedestalled \& intervals roots exposed intervals
4 Rills at 5-10' intervals
1 No visual evidence

4 Rills at $5-10$

5 Rills at $<5^{\prime}$ intervals

Rating

Rating

Rating

Total

Erosion Condition Class

Stable

Slight

Moderate

Critical

Severe 


\section{ATTACHMENT F}

\section{SURVEY RESULTS FOR CAU 424 AND CAU 427}


Date: April 2004

THIS PAGE INTENTIONALLY LEFT BLANK 


\section{Survey Results for CAU 424 and CAU 427}

This Attachment includes the following survey information gathered on July 9, 2003:

- CAU 424 Landfill Cells A3-1 and A3-4 survey data,

- CAU 424 Landfill Cells A3-1 and A3-4 elevation contour maps,

- CAU 424 Landfill Cells A3-1 and A3-4 topographic cross sections

- CAU 427 field measurements to aid in locating the subsurface leachfield markers

CAU 427 subsurface markers can be located by measuring the distances from the building corners as indicated on the enclosed drawings. Subsurface markers will be present where two intersecting measurements meet. 
CAU 424 LANDFILC A3-1

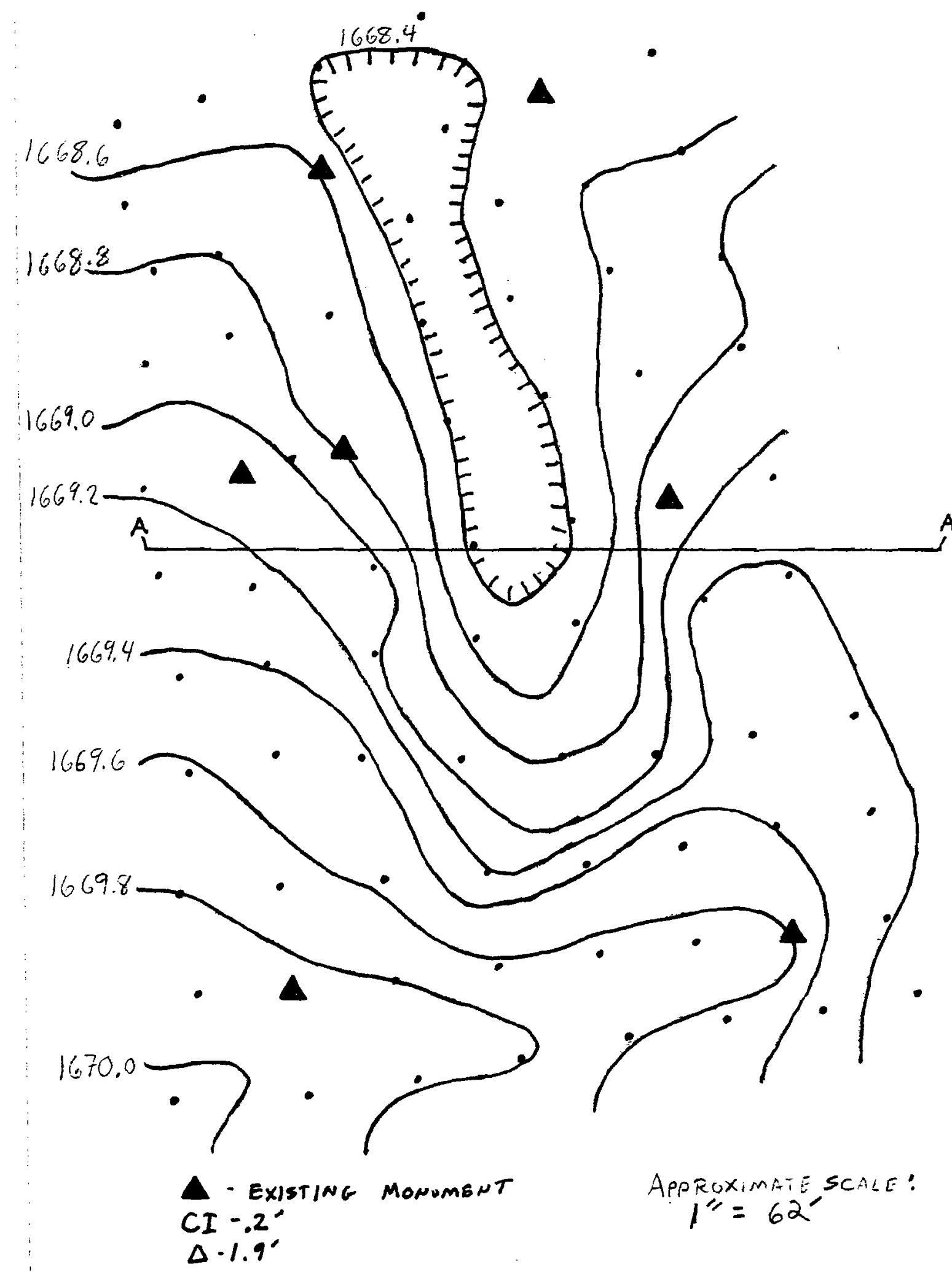


CAU 424 Landfill Cell A3-1

Elevation Survey

\begin{tabular}{|c|c|c|c|c|c|}
\hline Survey $\mathrm{Pt}$ & Northing & Easting & Elev & Measurement & Differential \\
\hline 3 & 6337371.707 & 491780.8425 & 1670.142072 & SPOT-ELEVATION & 1.9 \\
\hline 4 & 6337372.456 & 491800.4245 & 1669.938969 & SPOT-ELEVATION & 1.7 \\
\hline 5 & 6337374.33 & 491816.5986 & 1669.834376 & SPOT-ELEVATION & 1.6 \\
\hline 6 & 6337376.942 & 491832.0036 & 1669.796664 & SPOT-ELEVATION & 1.5 \\
\hline 7 & 6337379.742 & 491847.7805 & 1669.616327 & SPOT-ELEVATION & 1.4 \\
\hline 8 & 6337382.045 & 491862.7397 & 1669.498949 & SPOT-ELEVATION & 1.2 \\
\hline 9 & 6337382.744 & 491876.7126 & 1669.330954 & SPOT-ELEVATION & 1.1 \\
\hline 10 & 6337385.311 & 491890.606 & 1669.066055 & SPOT-ELEVATION & 0.8 \\
\hline 11 & 6337396.599 & 491886.5532 & 1669.228072 & SPOT-ELEVATION & 1.0 \\
\hline 12 & 6337394.02 & 491858.4461 & 1669.675726 & SPOT-ELEVATION & 1.4 \\
\hline 13 & 6337392.452 & 491843.8985 & 1669.66143 & SPOT-ELEVATION & $\overline{1.4}$ \\
\hline 14 & 6337390.916 & 491829.191 & 1669.667845 & SPOT-ELEVATION & 1.4 \\
\hline 15 & 6337389.243 & 491813.9325 & 1669.768786 & SPOT-ELEVATION & 1.5 \\
\hline 16 & 6337387.597 & 491784.5941 & 1669.949817 & SPOT-ELEVATION & 1.7 \\
\hline 17 & 6337402.734 & 491782.1989 & 1669.82747 & SPOT-ELEVATION & 1.6 \\
\hline 18 & 6337403.43 & 491796.5298 & 1669.724735 & SPOT-ELEVATION & 1.5 \\
\hline 19 & 6337404.051 & 491811.7055 & 1669.608374 & SPOT-ELEVATION & 1.4 \\
\hline 20 & 6337404.663 & 491827.4013 & 1669.309255 & SPOT-ELEVATION & 1.1 \\
\hline 21 & 6337405.631 & 491842.0597 & 1669.436644 & SPOT-ELEVATION & 1.2 \\
\hline 22 & 6337408.087 & 491856.4792 & 1669.502733 & SPOT-ELEVATION & 1.2 \\
\hline 23 & 6337410.403 & 491870.4793 & 1669.442586 & SPOT-ELEVATION & 1.2 \\
\hline 24 & 6337412.327 & 491884.4444 & 1669.293731 & SPOT-ELEVATION & 1.0 \\
\hline 25 & 6337426.94 & 491882.3827 & 1669.24353 & SPOT-ELEVATION & 1.0 \\
\hline 26 & 6337424.468 & 491867.1736 & 1669.351842 & SPOT-ELEVATION & 1.1 \\
\hline 27 & 6337421.867 & 491852.5685 & 1669.019125 & SPOT-ELEVATION & 0.8 \\
\hline 28 & 6337421.917 & 491838.8767 & 1668.76543 & SPOT-ELEVATION & 0.5 \\
\hline 29 & 6337421.722 & 491823.909 & 1669.007093 & SPOT-ELEVATION & 0.8 \\
\hline 30 & 6337422.581 & 491809.2202 & 1669.461211 & SPOT-ELEVATION & 1.2 \\
\hline 31 & 6337422.954 & 491796.4087 & 1669.553743 & SPOT-ELEVATION & 1.3 \\
\hline$\overline{32}$ & 6337420.911 & 491783.6871 & 1669.670406 & SPOT-ELEVATION & $\overline{1.4}$ \\
\hline 33 & 6337435.031 & 491782.7955 & 1669.483389 & SPOT-ELEVATION & 1.2 \\
\hline 34 & 6337436.482 & 491795.8163 & 1669.381749 & SPOT-ELEVATION & 1.1 \\
\hline 35 & 6337437.76 & 491811.3278 & 1669.054988 & SPOT-ELEVATION & 0.8 \\
\hline 36 & 6337439.866 & 491826.4375 & 1668.57733 & SPOT-ELEVATION & 0.3 \\
\hline 37 & 6337441.748 & 491841.4852 & 1668.601876 & SPOT-ELEVATION & 0.3 \\
\hline 38 & 6337444.646 & 491860.3332 & 1669.17359 & SPOT-ELEVATION & 0.9 \\
\hline 39 & 6337448.119 & 491873.4949 & 1669.192157 & SPOT-ELEVATION & 0.9 \\
\hline 40 & 6337462.712 & 491871.0429 & 1669.067442 & SPOT-ELEVATION & 0.8 \\
\hline 41 & $6337457: 149$ & 491840.9074 & 1668.357037 & SPOT-ELEVATION & 0.1 \\
\hline 42 & 6337453.695 & 491826.2028 & 1668.421506 & SPOT-ELEVATION & 0.2 \\
\hline 43 & 6337450.678 & 491811.4957 & 1669.070626 & SPOT-ELEVATION & 0.8 \\
\hline 44 & 6337448.008 & 491793.8182 & 1669.267307 & SPOT-ELEVATION & 1.0 \\
\hline 45 & 6337450.142 & 491780.0374 & 1669.307505 & SPOT-ELEVATION & $\overline{1.1}$ \\
\hline 46 & 6337463.063 & 491777.9877 & 1669.185443 & SPOT-ELEVATION & 0.9 \\
\hline 47 & 6337467.164 & 491799.596 & 1669.049035 & SPOT-ELEVATION & $\overline{0.8}$ \\
\hline$\overline{48}$ & 6337472.415 & 491822.7759 & 1668.364626 & SPOT-ELEVATION & 0.1 \\
\hline 49 & 6337475.477 & 491837.4221 & 1668.396051 & SPOT-ELEVATION & 0.1 \\
\hline 50 & 6337478.645 & 491851.2653 & 1668.683731 & SPOT-ELEVATION & 0.4 \\
\hline 51 & 6337481.998 & 491866.5454 & 1668.838892 & SPOT-ELEVATION & 0.6 \\
\hline 52 & 6337495.208 & 491863.7924 & 1668.815909 & SPOT-ELEVATION & 0.6 \\
\hline 53 & 6337493.642 & 491847.3069 & 1668.653226 & SPOT-ELEVATION & 0.4 \\
\hline 54 & 6337489.87 & 491832.3584 & 1668.476416 & SPOT-ELEVATION & 0.2 \\
\hline
\end{tabular}


CAU 424 Landfill Cell A3-1

Elevation Survey

\begin{tabular}{|c|l|l|l|l|c|}
\hline Survey Pt & \multicolumn{1}{|c|}{ Northing } & \multicolumn{1}{c|}{ Easting } & \multicolumn{1}{c|}{ Elev } & \multicolumn{1}{c|}{ Measurement } & Differential \\
\hline 55 & 6337486.497 & 491819.1659 & 1668.439683 & SPOT-ELEVATION & 0.2 \\
\hline 56 & 6337487.93 & 491805.6758 & 1668.68536 & SPOT-ELEVATION & 0.4 \\
\hline 57 & 6337485.48 & 491790.6427 & 1668.876682 & SPOT-ELEVATION & 0.6 \\
\hline 58 & 6337481.406 & 491778.7777 & 1668.812967 & SPOT-ELEVATION & 0.6 \\
\hline 59 & 6337495.165 & 491779.9916 & 1668.846582 & SPOT-ELEVATION & 0.6 \\
\hline 60 & 6337497.575 & 491789.5662 & 1668.759496 & SPOT-ELEVATION & 0.5 \\
\hline 61 & 6337499.251 & 491804.9077 & 1668.671238 & SPOT-ELEVATION & 0.4 \\
\hline 62 & 6337501.83 & 491817.6275 & 1668.25685 & SPOT-ELEVATION & 0.0 \\
\hline 63 & 6337504.236 & 491831.0121 & 1668.466503 & SPOT-ELEVATION & 0.2 \\
\hline 64 & 6337506.646 & 491843.9255 & 1668.572297 & SPOT-ELEVATION & 0.3 \\
\hline 65 & 6337511.294 & 491858.2695 & 1668.568005 & SPOT-ELEVATION & 0.3 \\
\hline 66 & 6337525.826 & 491854.0976 & 1668.483318 & SPOT-ELEVATION & 0.2 \\
\hline 67 & 6337538.623 & 491850.515 & 1668.496581 & SPOT-ELEVATION & 0.2 \\
\hline 68 & 6337536.466 & 491833.1701 & 1668.509542 & SPOT-ELEVATION & 0.3 \\
\hline 69 & 6337532.045 & 491819.7973 & 1668.549786 & SPOT-ELEVATION & 0.3 \\
\hline 70 & 6337515.264 & 491823.3442 & 1668.443491 & SPOT-ELEVATION & 0.2 \\
\hline 71 & 6337525.008 & 491804.4012 & 1668.445333 & SPOT-ELEVATION & 0.2 \\
\hline 72 & 6337520.462 & 491787.6724 & 1668.538799 & SPOT-ELEVATION & 0.3 \\
\hline 73 & 6337517.119 & 491775.0621 & 1668.540499 & SPOT-ELEVATION & 0.3 \\
\hline 74 & 6337503.798 & 491775.5082 & 1668.721433 & SPOT-ELEVATION & 0.5 \\
\hline 75 & 6337510.73 & 491804.8973 & 1668.609928 & GRND.@ MON. & 0.4 \\
\hline 76 & 6337520.776 & 491837.7549 & 1668.469435 & GRND.@ MON. & 0.2 \\
\hline 77 & 6337460.51 & 491855.6317 & 1668.868631 & GRND.@ MON. & 0.6 \\
\hline 78 & 6337469.026 & 491807.4539 & 1668.762499 & GRND.@ MON. & 0.5 \\
\hline 79 & 6337465.768 & 491792.7045 & 1669.024415 & GRND.@ MON. & 0.8 \\
\hline 80 & 6337395.546 & 491872.7434 & 1669.566023 & GRND.@ MON. & 1.3 \\
\hline 81 & 6337388.766 & 491798.6862 & 1669.8767 & GRND.@ MON. & 1.6 \\
\hline & & & & & \\
\hline
\end{tabular}


CAU 424 LANDFICL A3-4
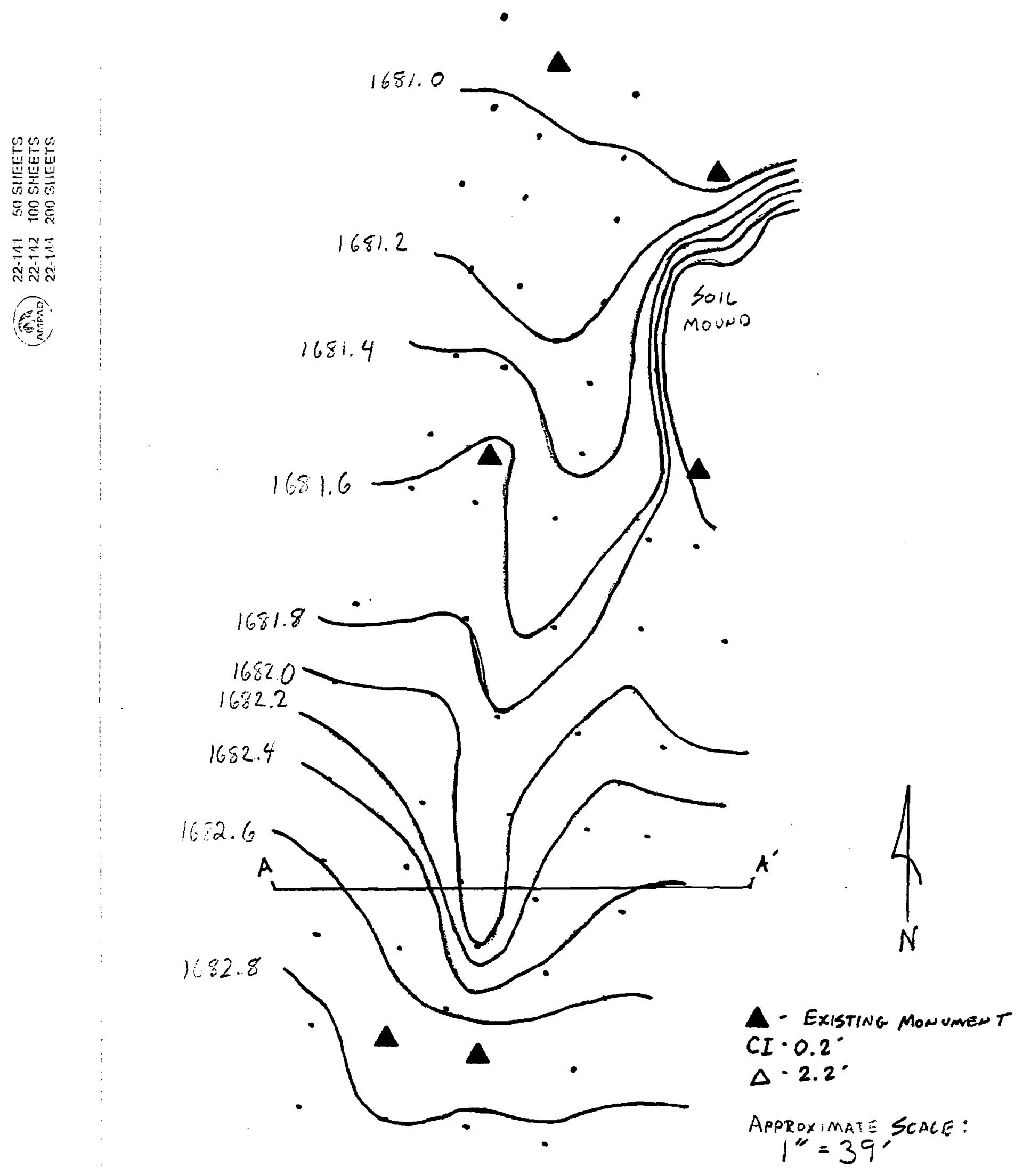


\begin{tabular}{|c|c|c|c|c|c|}
\hline Survey Pt & Northing & Easting & Elev & Measurement & Differential \\
\hline 3 & 6336190.883 & 491695.9754 & 1683.017454 & SPOT-ELEVATION & 2.2 \\
\hline 4 & 6336188.792 & 491710.6766 & 1682.882963 & SPOT-ELEVATION & 2.1 \\
\hline 5 & 6336187.093 & 491723.4305 & 1683.008378 & SPOT-ELEVATION & 2.2 \\
\hline 6 & 6336185.173 & 491737.0642 & 1682.911293 & SPOT-ELEVATION & 2.1 \\
\hline 7 & 6336198.525 & 491740.1059 & 1682.736743 & SPOT-ELEVATION & 1.9 \\
\hline 8 & 6336201.861 & 491718.5693 & 1682.687695 & SPOT-ELEVATION & 1.9 \\
\hline 9 & 6336204.977 & 491697.219 & 1682.937023 & SPOT-ELEVATION & 2.1 \\
\hline 10 & 6336219.888 & 491698.4266 & 1682.681939 & SPOT-ELEVATION & 1.9 \\
\hline$\overline{11}$ & 6336217.699 & 491712.488 & 1682.582649 & SPOT-ELEVATION & 1.8 \\
\hline 12 & 6336217.64 & 491726.5898 & 1682.008238 & SPOT-ELEVATION & 1.2 \\
\hline 13 & 6336213.216 & 491738.5961 & 1682.590345 & SPOT-ELEVATION & 1.8 \\
\hline 14 & 6336209.978 & 491746.6671 & 1682.689429 & SPOT-ELEVATION & 1.9 \\
\hline 15 & 6336224.054 & 491749.9406 & 1682.580538 & SPOT-ELEVATION & 1.8 \\
\hline 16 & 6336226.411 & 491735.4469 & 1682.19895 & SPOT-ELEVATION & $\overline{1.4}$ \\
\hline 17 & 6336229.127 & 491721.374 & 1682.095006 & SPOT-ELEVATION & 1.3 \\
\hline 18 & 6336230.614 & 491713.9822 & 1682.516109 & SPOT-ELEVATION & 1.7 \\
\hline 19 & 6336232.352 & 491699.6809 & 1682.618537 & SPOT-ELEVATION & 1.8 \\
\hline 20 & 6336246.37 & 491700.8258 & 1682.407549 & SPOT-ELEVATION & $\overline{1.6}$ \\
\hline 21 & 6336243.389 & 491716.8791 & 1682.204586 & SPOT-ELEVATION & $\overline{1.4}$ \\
\hline 22 & 6336240.889 & 491730.4891 & 1682.031594 & SPOT-ELEVATIION & $\overline{1.2}$ \\
\hline 23 & 6336237.958 & 491744.5389 & 1682.190711 & SPOT-ELEVATION & 1.4 \\
\hline 24 & 6336236.659 & 491753.0443 & 1682.175053 & SPOT-ELEVATION & 1.4 \\
\hline 25 & 6336252.245 & 491756.8338 & 1681.82073 & SPOT-ELEVATION & 1.0 \\
\hline 26 & 6336255.118 & 491743.0172 & 1681.718672 & SPOT-ELEVATION & 0.9 \\
\hline 27 & 6336258.069 & 491729.8203 & 1681.845048 & SPOT-ELEVATION & 1.1 \\
\hline 28 & 6336260.873 & 491719.3012 & 1682.10646 & SPOT-ELEVATION & 1.3 \\
\hline 29 & 6336263.419 & 491702.5441 & 1682.095763 & SPOT-ELEVATION & 1.3 \\
\hline 30 & 6336276.203 & 491704.8482 & 1681.759901 & SPOT-ELEVATION & 1.0 \\
\hline 31 & 6336275.22 & 491722.7032 & 1681.863677 & SPOT-ELEVATION & 1.1 \\
\hline 32 & 6336274.605 & 491737.8023 & 1681.658192 & SPOT-ELEVATION & 0.9 \\
\hline 33 & 6336273.071 & 491752.1656 & 1681.879324 & SPOT-ELEVATION & 1.1 \\
\hline 34 & 6336271.571 & 491766.4538 & 1681.872604 & SPOT-ELEVATION & 1.1 \\
\hline 35 & 6336285.358 & 491761.4657 & 1681.894953 & SPOT-ELEVATION & 1.1 \\
\hline 36 & 6336286.067 & 491754.7284 & 1681.873697 & SPOT-ELEVATION & 1.1 \\
\hline 37 & 6336289.476 & 491739.4538 & 1681.598493 & SPOT-ELEVATION & 0.8 \\
\hline 38 & 6336292.294 & 491725.5145 & 1681.724447 & SPOT-ELEVATION & 0.9 \\
\hline 39 & 6336295.151 & 491713.8996 & 1681.630219 & SPOT-ELEVATION & 0.8 \\
\hline 40 & 6336303.237 & 491717.8115 & 1681.590238 & SPOT-ELEVATION & 0.8 \\
\hline 41 & 6336299.142 & 491743.4458 & 1681.452685 & SPOT-ELEVATION & 0.7 \\
\hline 42 & 6336312.827 & 491745.4371 & 1681.408927 & SPOT-ELEVATION & 0.6 \\
\hline 43 & 6336315.703 & 491729.991 & 1681.499752 & SPOT-ELEVATION & 0.7 \\
\hline 44 & 6336316.543 & 491722.513 & 1681.43659 & SPOT-ELEVATION & 0.6 \\
\hline 45 & 6336330.704 & 491725.3201 & 1681.264747 & SPOT-ELEVATION & 0.5 \\
\hline 46 & 6336329.364 & 491732.2125 & 1681.331828 & SPOT-ELEVATION & 0.5 \\
\hline 47 & 6336325.392 & 491747.4025 & 1681.234053 & SPOT-ELEVATION & 0.4 \\
\hline 48 & 6336339.376 & 491749.4694 & 1681.187797 & SPOT-ELEVATION & 0.4 \\
\hline 49 & 6336343.27 & 491734.2231 & 1681.146536 & SPOT-ELEVATION & 0.4 \\
\hline 50 & 6336345.3 & 491723.5042 & 1681.177175 & SPOT-ELEVATION & 0.4 \\
\hline 51 & 6336358.657 & 491728.2207 & 1681.113415 & SPOT-ELEVATION & 0.3 \\
\hline 52 & 6336354.939 & 491736.0144 & 1681.161305 & SPOT-ELEVATION & 0.4 \\
\hline 53 & 6336349.148 & 491750.6891 & 1681.099561 & SPOT-ELEVATION & 0.3 \\
\hline 54 & 6336360.866 & 491752.6569 & 1680.974033 & SPOT-ELEVATION & 0.2 \\
\hline
\end{tabular}


CAU 424 Landfill Cell A3-4

Elevation Survey

\begin{tabular}{|c|l|l|l|l|c|}
\hline Survey Pt & \multicolumn{1}{|c|}{ Northing } & \multicolumn{1}{c|}{ Easting } & \multicolumn{1}{c|}{ Elev } & \multicolumn{1}{c|}{ Measurement } & Differential \\
\hline 55 & 6336373.6 & 491730.2631 & 1680.883345 & SPOT-ELEVATION & 0.1 \\
\hline 151 & 6336347.514 & 491768.5028 & 1680.95458 & GRND. @ MON.LOC. & 0.2 \\
\hline 152 & 6336367.274 & 491739.9238 & 1680.787142 & GRND. @ MON.LOC. & 0.0 \\
\hline 153 & 6336302.094 & 491727.8102 & 1681.731977 & GRND. @ MON.LOC. & 0.9 \\
\hline 154 & 6336297.143 & 491761.3616 & 1681.765364 & GRND. @ MON.LOC. & 1.0 \\
\hline 155 & 6336200.583 & 491724.7878 & 1682.777038 & GRND. @ MON.LOC. & 2.0 \\
\hline 156 & 6336202.963 & 491712.188 & 1682.758781 & GRND. @ MON.LOC. & 2.0 \\
\hline
\end{tabular}


TOPOGRAPHIC

CROSS - SBCTION

CAU 424 LANDPIC A3-4

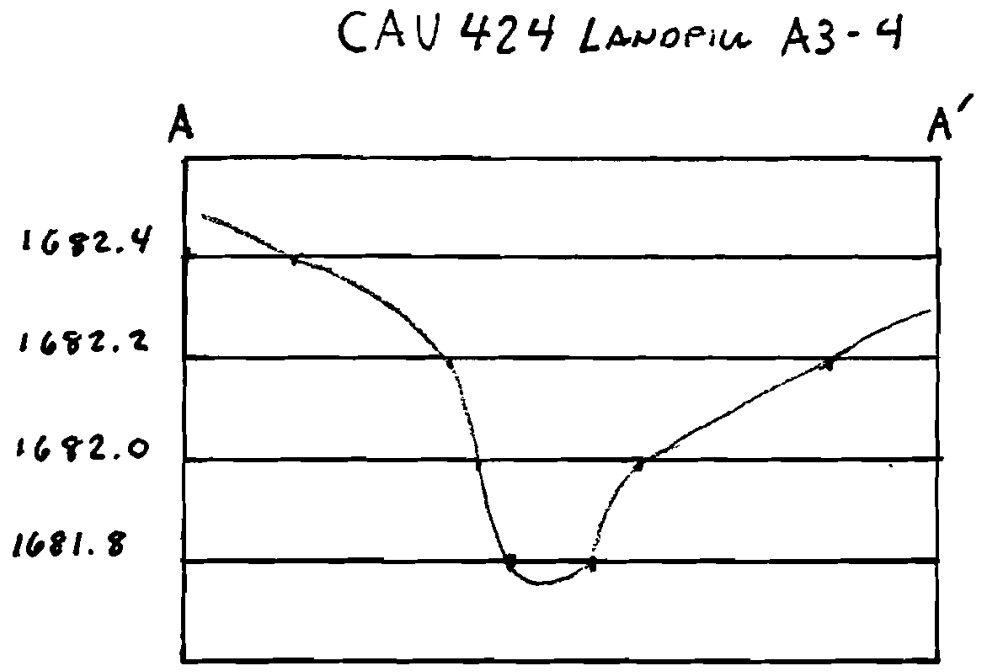

CAV 424 LandFILL A 3-1

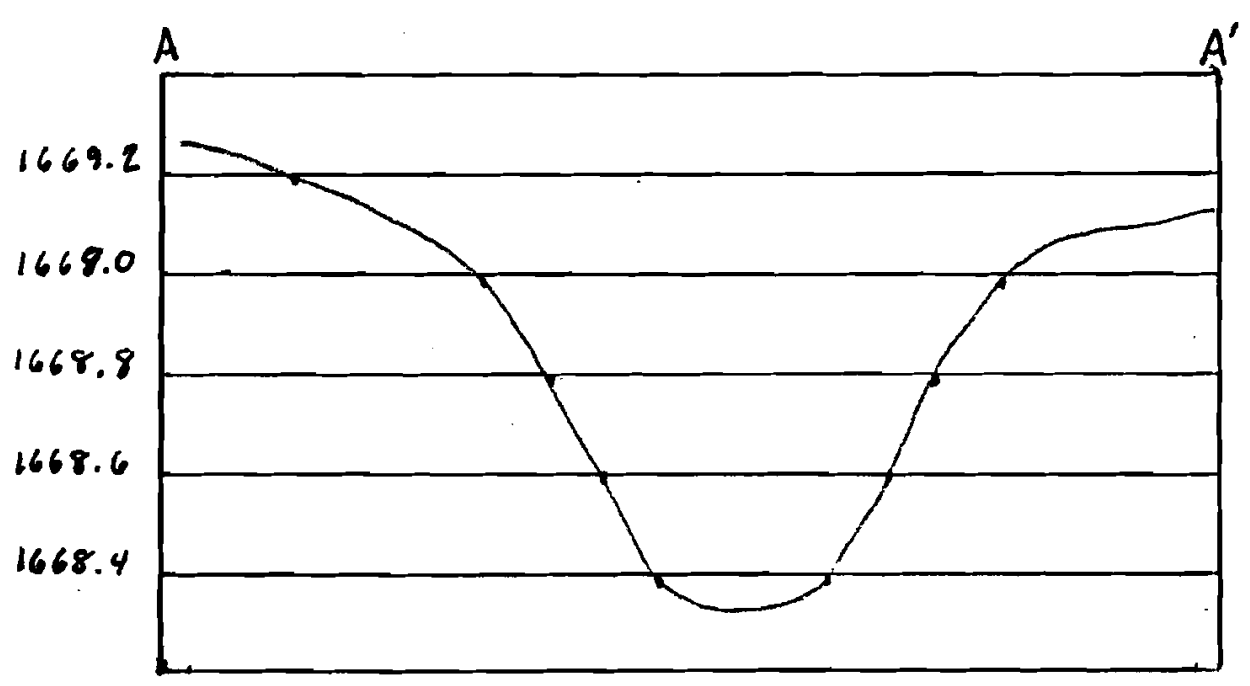

* Vertical scale exaggerateo 


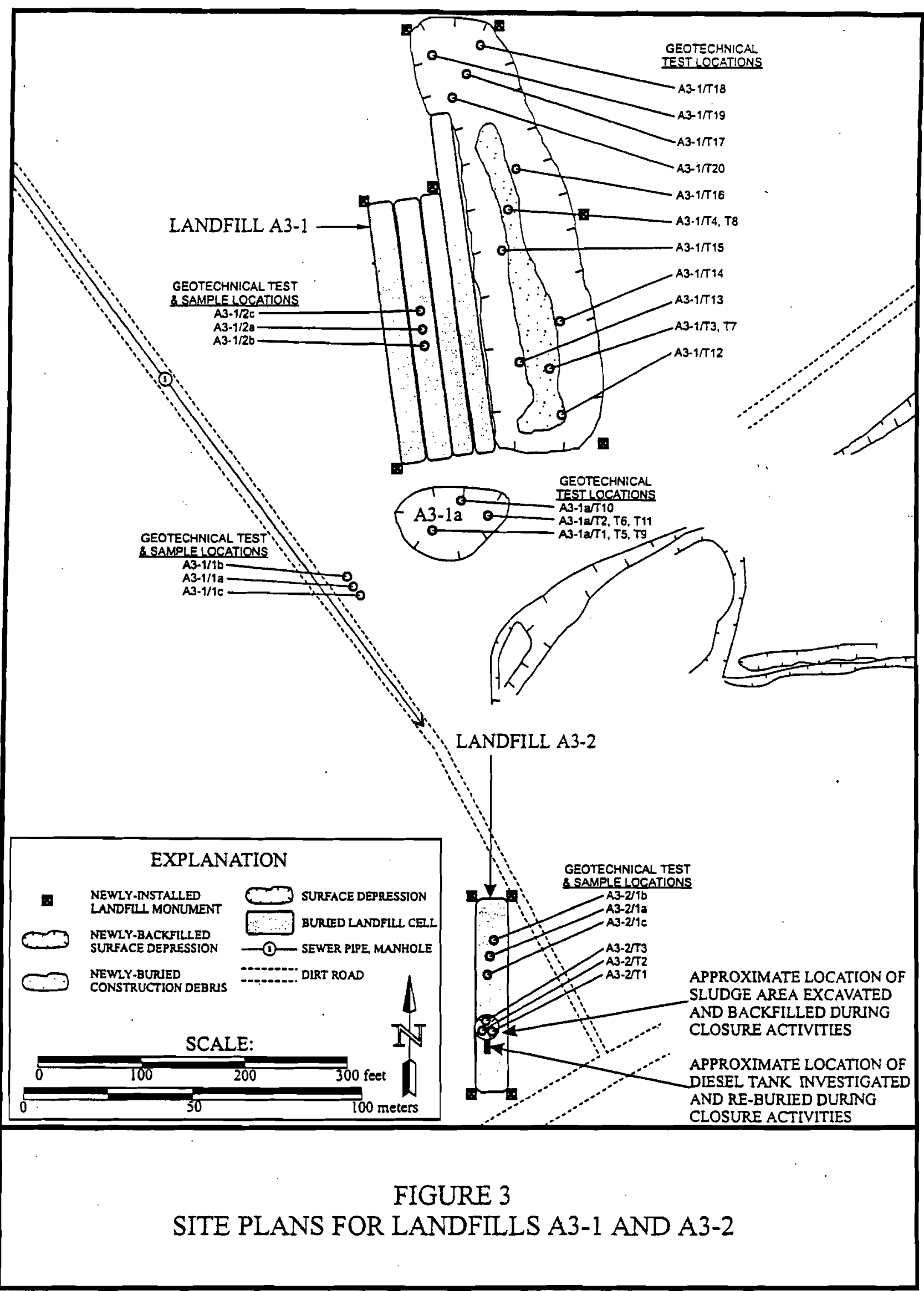




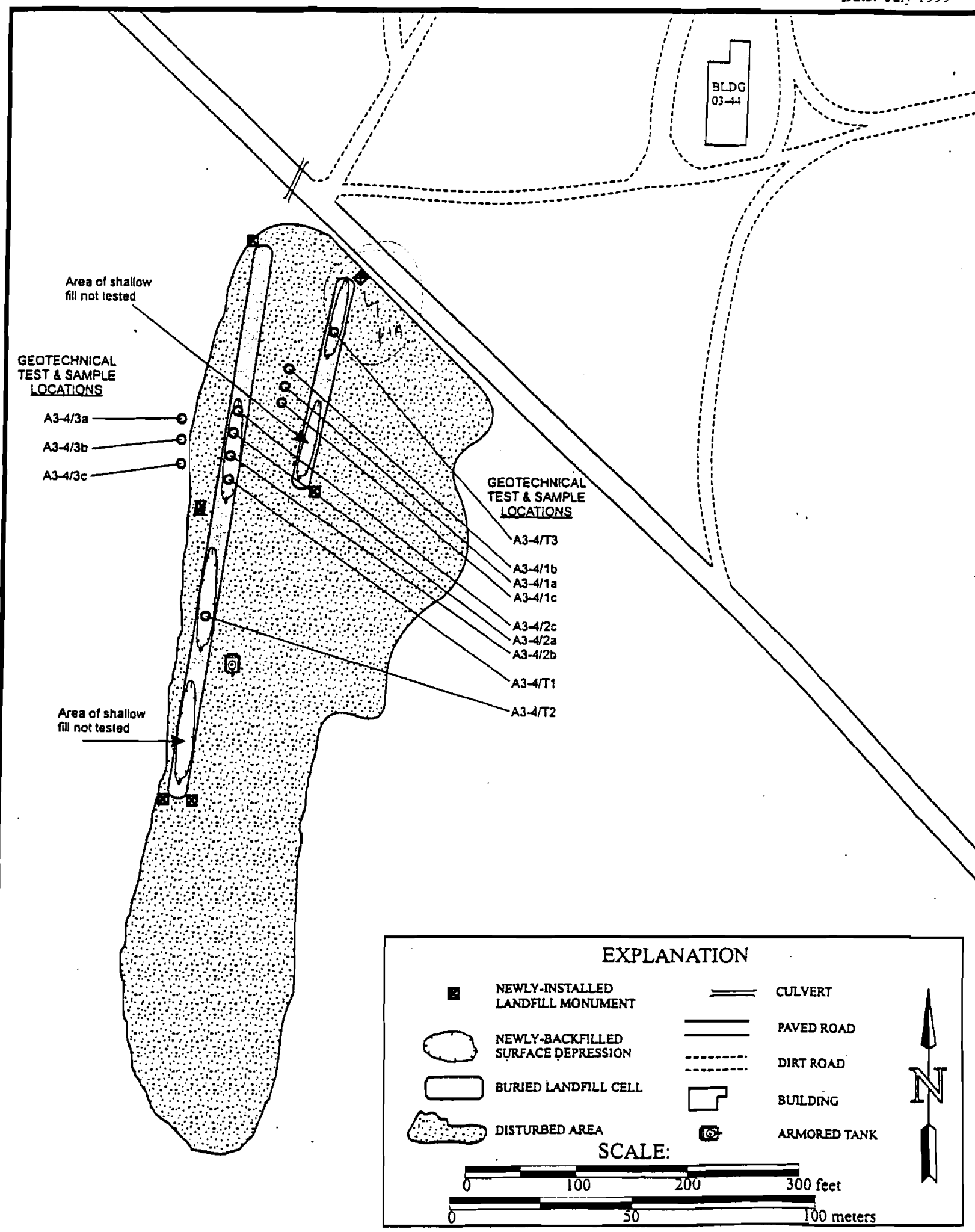

FIGURE 5

SITE PLAN FOR LANDFILL A3-4 

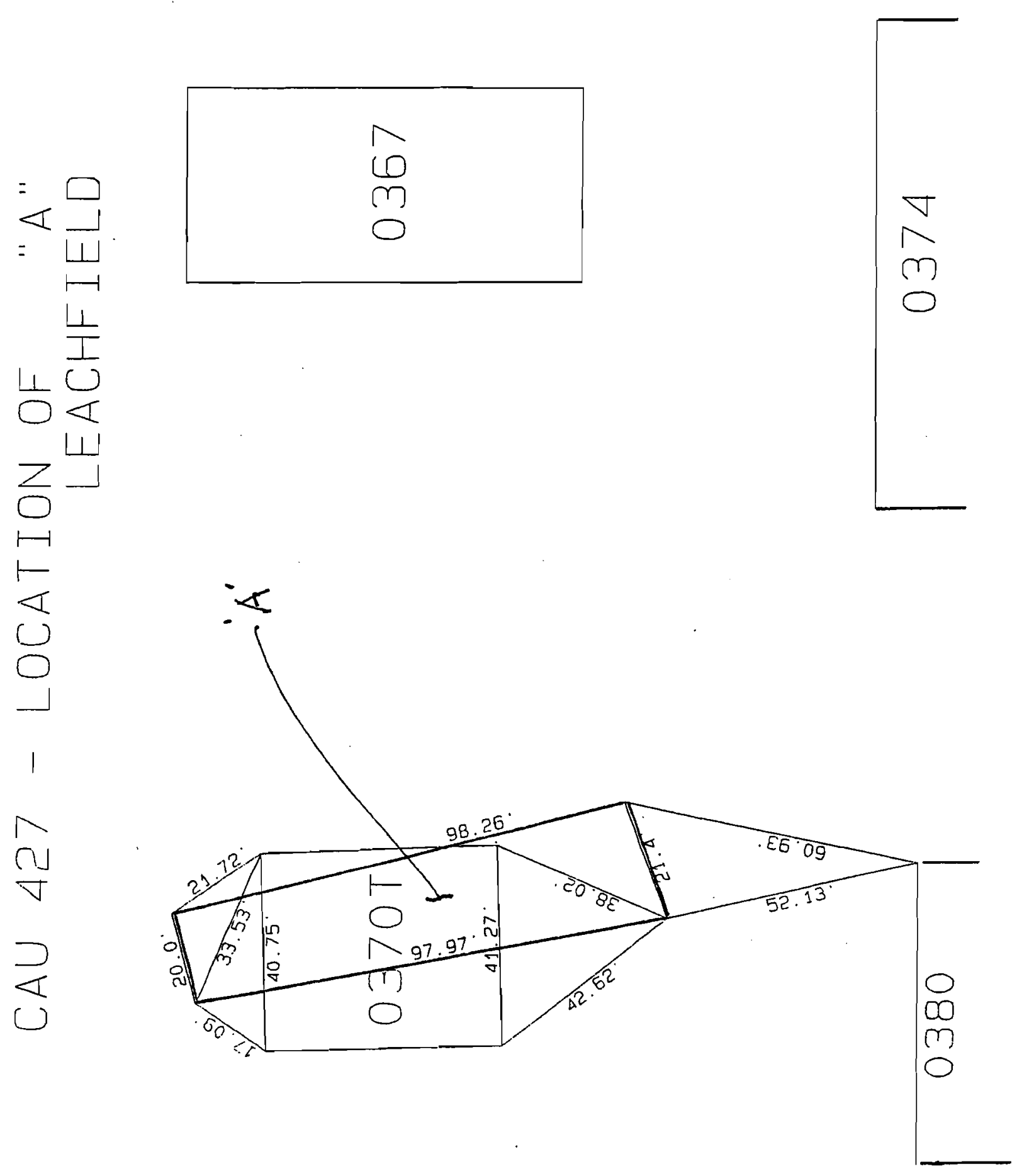

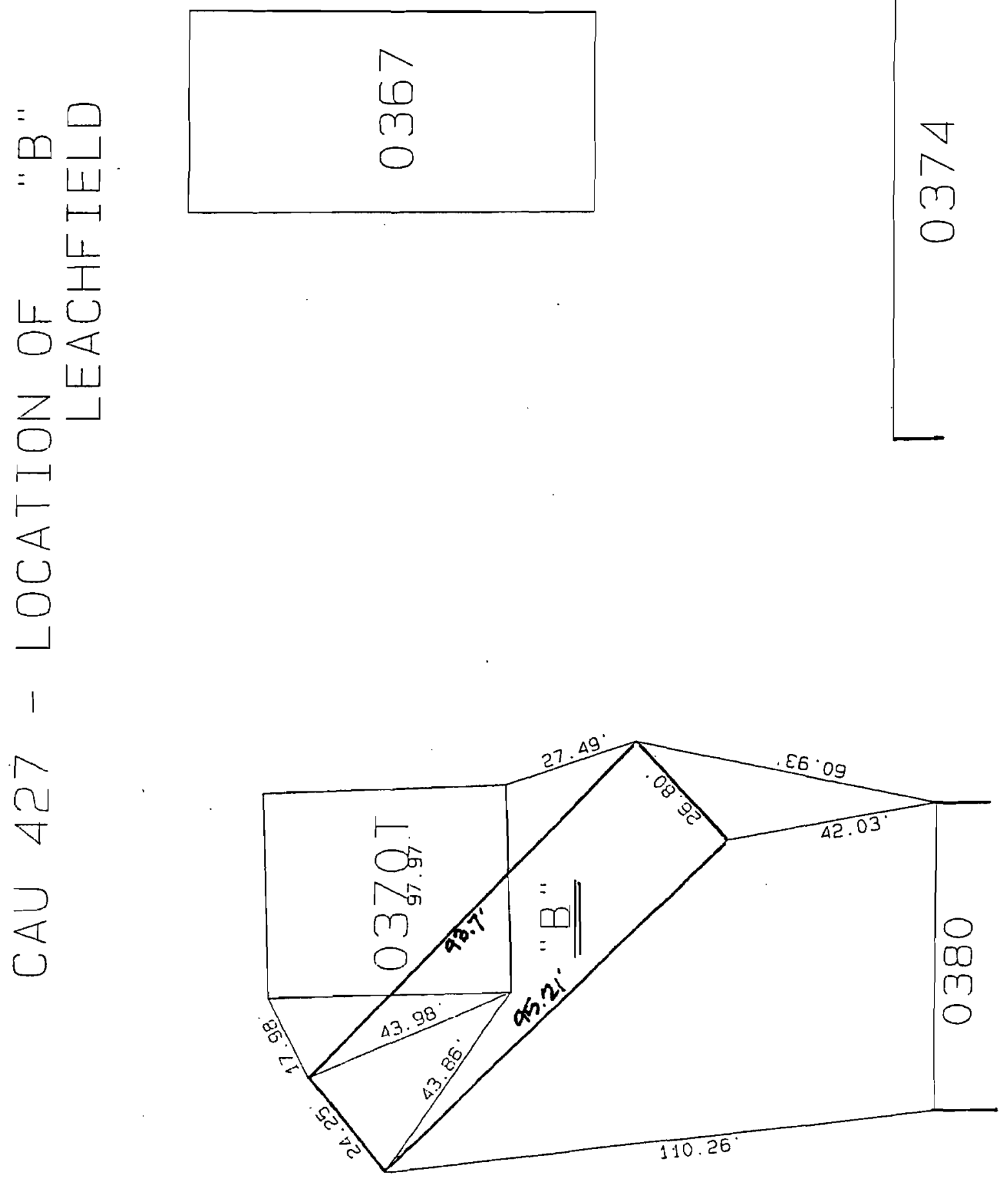

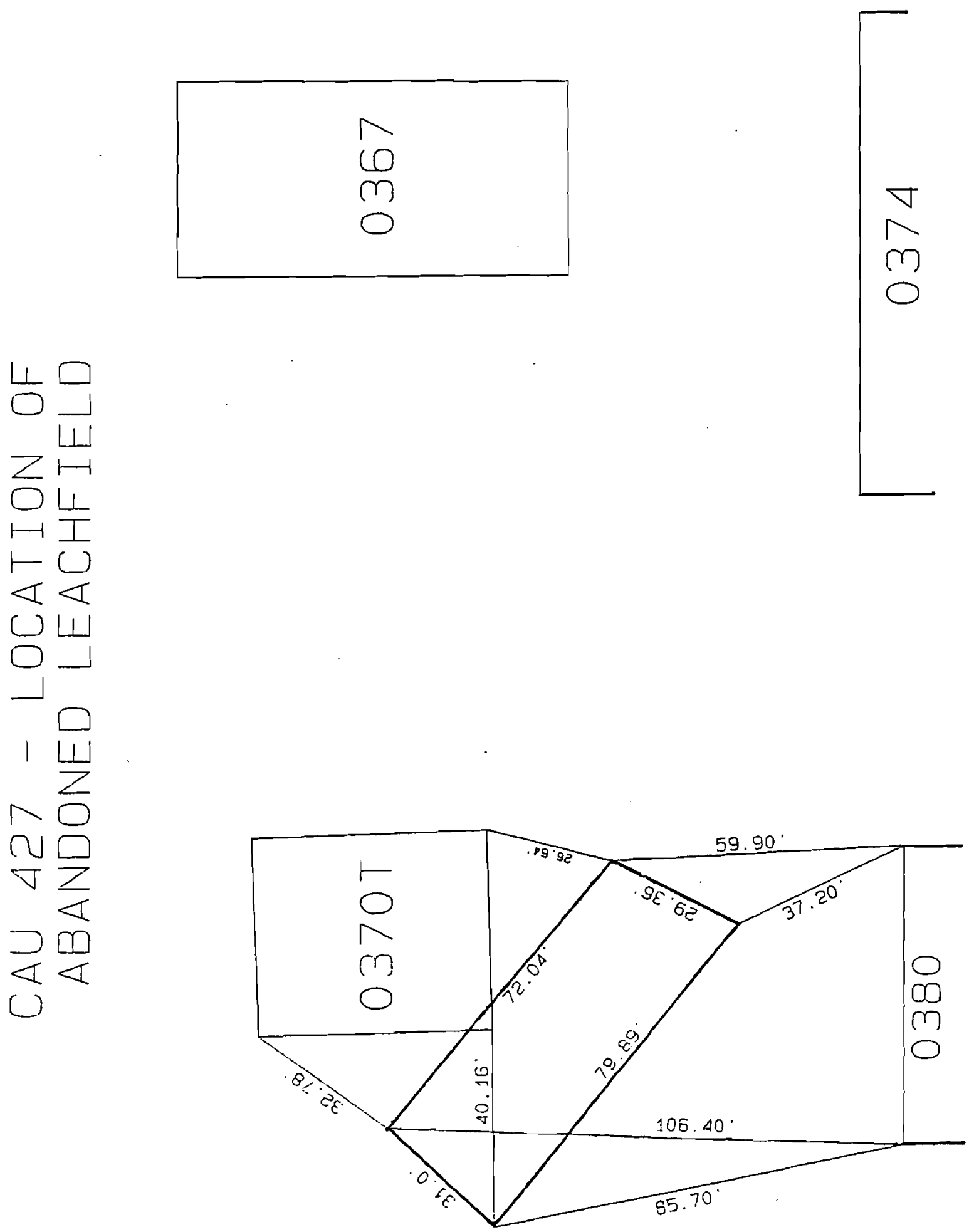

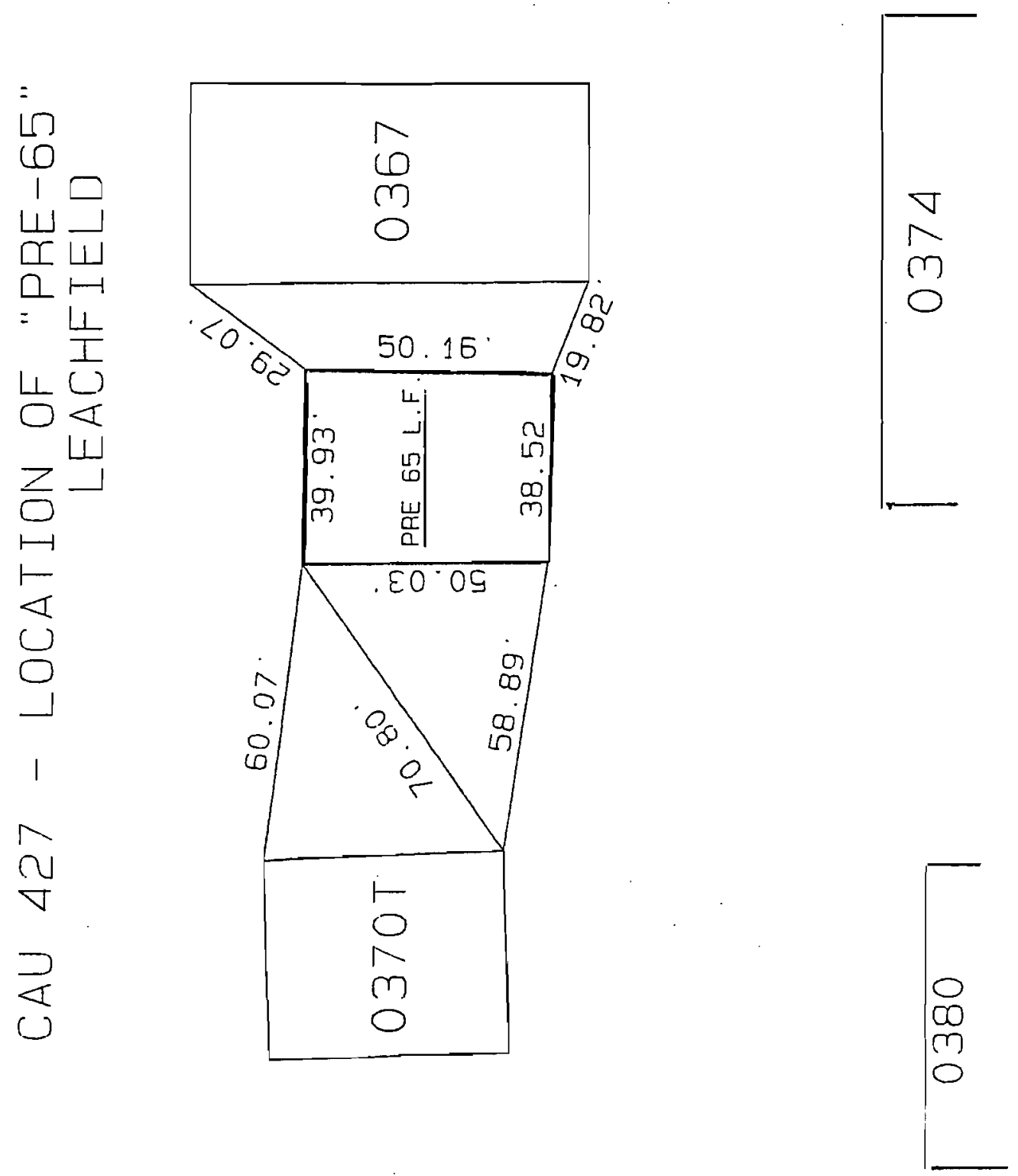
Date: April 2004

\section{DISTRIBUTION LIST}


Date: April 2004 


\section{DISTRIBUTION LIST}

*Distribute only NDEP-approved revisions; others receive all revisions.

\section{Nevada Division of Environmental Protection}

Ms. Terre A. Maize, Chief

1 (Controlled)

Bureau of Federal Facilities

Division of Environmental Protection

1771 East Flamingo Road, Suite 121-A

Las Vegas, NV 89119-0837

Bureau of Federal Facilities

1 (Controlled)

Division of Environmental Protection

333 W. Nye Lane, Room 138

Carson City, NV 89706-0851

Donald Elle

Bureau of Federal Facilities

1 (Controlled)

Division of Environmental Protection

1771 East Flamingo Road, Suite 121-A

Las Vegas, NV 89119-0837

\section{$\underline{\text { U.S. Department of Energy }}$}

Shirley Doty

1 (Controlled)

Environmental Restoration Division

U.S. Department of Energy

National Nuclear Security Administration Nevada Site Office

P.O. Box $98518, \mathrm{M} / \mathrm{S} 505$

Las Vegas, NV 89193-8518

Kevin Cabble

1 (Uncontrolled)

Environmental Restoration Division

U.S. Department of Energy

National Nuclear Security Administration Nevada Site Office

P.O. Box $98518, \mathrm{M} / \mathrm{S} 505$

Las Vegas, NV 89193-8518

Janet Appenzeller-Wing

1 (Uncontrolled)

Environmental Restoration Division

U.S. Department of Energy

National Nuclear Security Administration Nevada Site Office

P.O. Box 98518, M/S 505

Las Vegas, NV 89193-8518 


\section{DISTRIBUTION LIST (continued)}

*Distribute only NDEP-approved revisions; others receive all revisions.

\section{U.S. Department of Energy (continued)}

Southern Nevada Public Reading Facility

1 (Controlled)* \&

c/o Nuclear Testing Archive

1 (Uncontrolled)*

P.O. Box 98521, M/S 400

Las Vegas, NV 89193-8521

U.S. Department of Energy

1 (Uncontrolled)*

National Nuclear Security Administration Nevada Site Office

Technical Library

P.O. Box 98518 , M/S 505

Las Vegas, NV 89193-8518

U.S. Department of Energy

1 (Uncontrolled, electronic copy)*

Office of Scientific and Technical Information

P.O. Box 62

Oak Ridge, TN 37831-0062

U.S. Department of Energy

1 (Uncontrolled)*

National Nuclear Security Administration

Nevada Site Office

Technical Library

P.O. Box 98518

Las Vegas, NV 89193-8518

U.S. Department of Energy

National Nuclear Security Administration 1

1 (Controlled)* \&

Nevada Site Office

Southern Nevada Public Reading Facility

C/O Nuclear Testing Archive, M/S 400

P.O. Box 98521

Las Vegas, NV 89193-8521

U.S. Department of Energy

1 (Uncontrolled)*

Office of Scientific and Technical Information

1 (Uncontrolled Electronic)*

P.O. Box 62

Oak Ridge, TN 37831-0062

\section{Bechtel Nevada}

Correspondence Control

1 (Uncontrolled)

Bechtel Nevada

P.O. Box 98521, M/S CF008

Las Vegas, NV 89193-8521 


\section{DISTRIBUTION LIST (continued)}

*Distribute only NDEP-approved revisions; others receive all revisions.

\section{Bechtel Nevada (Continued)}

Environmental Management Library

1 (Uncontrolled)

Bechtel Nevada

P.O. Box 98521, M/S NLV080

Las Vegas, NV 89193-8521

Kevin Campbell

1 (Uncontrolled)

Bechtel Nevada

P.O. Box $98521, \mathrm{M} / \mathrm{S}$ NTS306

Las Vegas, NV 89193-8521

Brad Jackson

1 (Uncontrolled)

Bechtel Nevada

P.O. Box 98521, M/S NTS306

Las Vegas, NV 89193-8521

David Madsen

1 (Uncontrolled)

Bechtel Nevada

P.O. Box 98521, M/S NTS306

Las Vegas, NV 89193-8521

\section{$\underline{\text { Nye County }}$}

David Swanson

Assistant Project Administrator

Nye County

Department of Natural Resources and Federal Facilities

1210 E. Basin Road, Suite 6

Pahrump, NV 89060

\section{Stoller-Navarro Joint Venture}

Public Reading Room Coordinator

1 (Controlled)*

Stoller-Navarro Joint Venture

1 (Uncontrolled) \&

7710 W. Cheyenne Ave., Bldg. 3

Las Vegas, NV 89129

Brian Hoenes

1 (Uncontrolled)

Stoller-Navarro Joint Venture

7710 W. Cheyenne Ave., Bldg. 3

Las Vegas, NV 89129 


\section{DISTRIBUTION LIST (continued)}

*Distribute only NDEP-approved revisions; others receive all revisions.

\section{State of Nevada}

Manager, Northern Nevada FFACO

1 (Uncontrolled)*

FFACO Public Reading Facility

Nevada State Library and Archives Federal Publications

100 North Stewart Street

Carson City, NV 89701-4285

\section{$\underline{\text { U.S. Air Force }}$}

North Range Commander

1 (Uncontrolled)

RMO Building

3770 Duffer Drive

North Las Vegas, NV 89191

E. V. Hopper

3 (Uncontrolled)

U.S. Air Force

99ABW-EM

4349 Duffer Drive, Suite 1601

Nellis AFB, NV 89191-7007

U.S. Air Force

98th Range Wing, XPL

Nellis AFB, NV 89191-7007

U.S. Air Force

DOE Liaison Office

P.O. Box 98518 , M/S 505

Las Vegas, NV 89193-8518

1 (Uncontrolled)

\section{Sandia National Laboratories}

Vern Gabbard

1 (Uncontrolled)

Sandia National Laboratory/TTR

1 (Uncontrolled)

Box 871

Tonopah, NV 89049

Jerry Elliston

1 (Uncontrolled)

Westinghouse

P.O. Box 528

Tonopah, NV 89049 